\title{
Københavnsområdets geologi især baseret på citybaneundersøgelserne
}

\author{
$\mathrm{AF}$ \\ Erik Stenestad
}

\begin{abstract}
SUMMARY
Geology of the Copenhagen area

predominantly based on investigations

for an urban underground railway
\end{abstract}

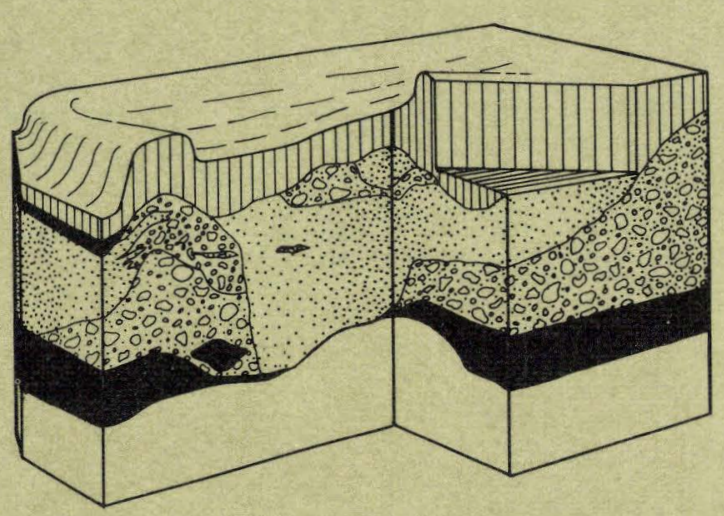


Danmarks Geologiske Undersøgelse. III. Række. Nr. 45

Geological Survey of Denmark. III. Series. No. 45

\section{Københavnsområdets geologi isar baseret på citybaneundersøgelserne}

Af

Erik Stenestad

Summary:

Geology of the Copenhagen area predominantly based on investigations for an urban underground railway

I kommission hos C.A. Reitzels Forlag København 1976 
D.G.U. III. rk. nr. 45

er sat med Fotosats Times

og trykt i offset i 1200 eksemplarer hos Andelsbogtrykkeriet i Odense.

Bogen er trykt på Thai-Cote, $115 \mathrm{~g}$ fra a/s De forenede Papirfabrikker. ISBN 87-421-0703-2

Date of publication: 1976-12-23 


\section{Indhold}

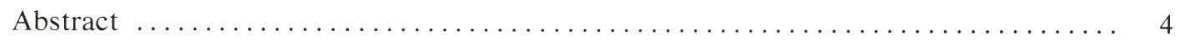

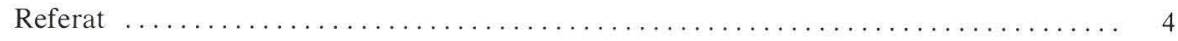

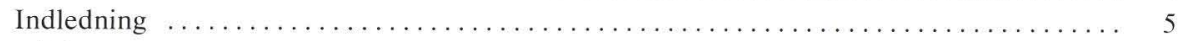

Tidligere geologiske undersøgelser i København $\ldots \ldots \ldots \ldots \ldots \ldots \ldots \ldots \ldots \ldots \ldots$

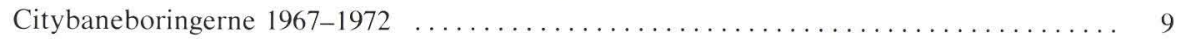

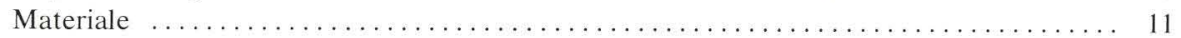

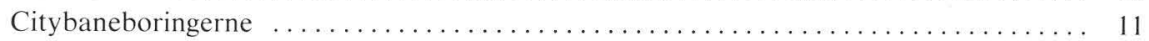

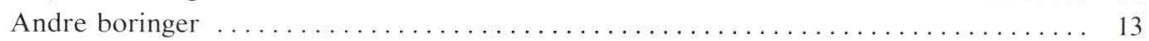

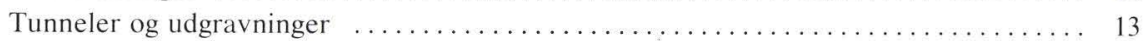

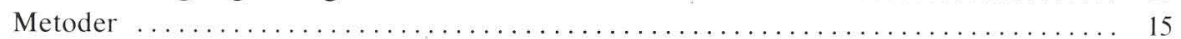

Lithologi og stratigrafi $\ldots \ldots \ldots \ldots \ldots \ldots \ldots \ldots \ldots \ldots \ldots \ldots \ldots \ldots \ldots \ldots \ldots \ldots \ldots \ldots$

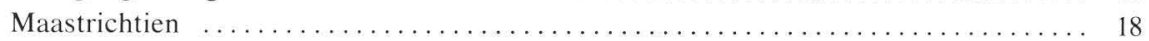

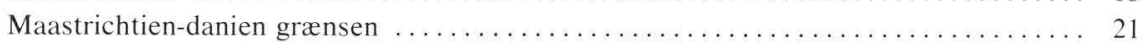

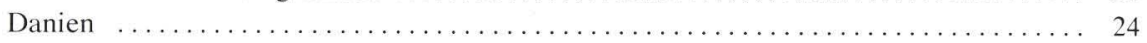

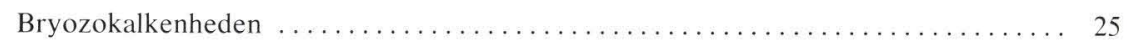

Grænsen mellem bryozokalkenheden og København Kalken ............ 33

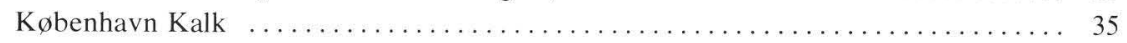

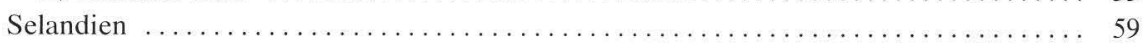

Lellinge Grønsand $\ldots \ldots \ldots \ldots \ldots \ldots \ldots \ldots \ldots \ldots \ldots \ldots \ldots \ldots \ldots \ldots \ldots$

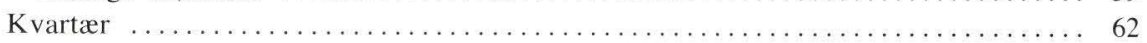

Sammenfatning. Lagserien og dens tilblivelseshistorie $\ldots \ldots \ldots \ldots \ldots \ldots \ldots \ldots \ldots \ldots 6$

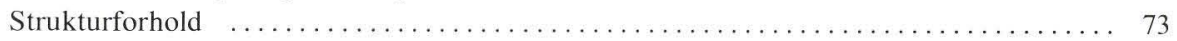

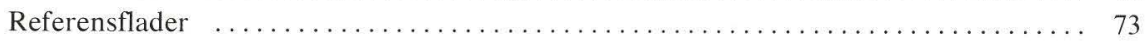

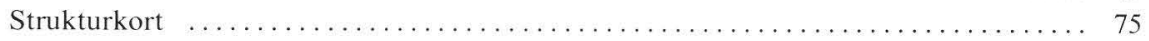

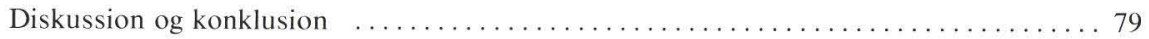

Områdebeskrivelser $\ldots \ldots \ldots \ldots \ldots \ldots \ldots \ldots \ldots \ldots \ldots \ldots \ldots \ldots \ldots \ldots \ldots$

Sydhavnen (Sydhavnstunnelen) $\ldots \ldots \ldots \ldots \ldots \ldots \ldots \ldots \ldots \ldots \ldots \ldots \ldots \ldots \ldots$

Området mellem Sydhavnen og Søerne ........................ 91

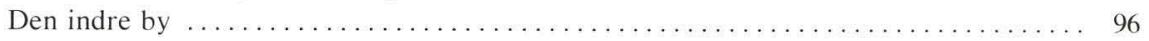

Området mellem Kgs. Nytorv $\operatorname{og} \emptyset_{\text {sterport station } \ldots \ldots \ldots \ldots \ldots \ldots \ldots \ldots \ldots \ldots \ldots}$

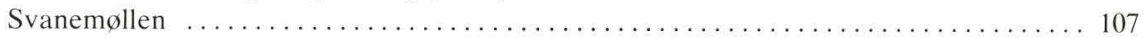

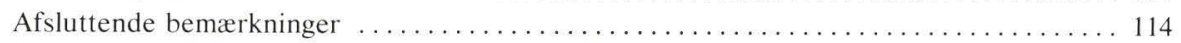

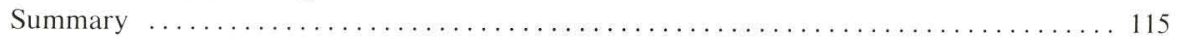

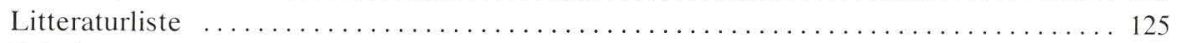

Tabel 1: Koteliste (fortegnelse over boringer i undersøgelsesområdet) . . . . . . . . 131

Tabel 2: Prøvebeskrivelse for boringen TUBA $13 \ldots \ldots \ldots \ldots \ldots \ldots \ldots \ldots \ldots \ldots \ldots$ 


\section{Abstract}

The lithostratigraphy of the Maastrichtian, Danian and Selandian deposits of Copenhagen is described and related to a biostratigraphical zonation based on foraminifera. The Quaternary deposits are briefly mentioned. The København Limestone Formation is formally introduced. The Lellinge Greensand Formation is emended and a reference section in Copenhagen is defined. The structures of the area are discussed on the basis of detailed subsurface mapping. The geology of the area is finally described in detail.

\section{Referat}

De københavnske maastrichtien-, danien- og selandienaflejringers lithostratigrafi beskrives og sættes i relation til en biostratigrafisk zonering, baseret på foraminiferer. De kvartære dannelser omtales kort. København Kalk Formationen introduceres formelt. Lellinge Grønsand Formationen emenderes og der defineres et referenceområde og et referenceprofil i København. De strukturelle forhold diskuteres på grundlag af detaljeret kortlægning. Til slut gives en detaljeret beskrivelse af fem områder i København fra Sydhavnen til Svanemøllen. 


\section{Indledning}

Allerede i den tidlige middelalder eksisterede der en vis viden om de geologiske forhold i København. Herom vidner alene placeringen af byen og dens forsvarsværker. Ved udgravningen af byens voldgrave, lergrave og brønde fik man yderligere kendskab til kvartærlagene, og lag af prækvartær alder kendte man fra Saltholm, hvor kalksten fra danientiden har været brudt gennem hele byens historie.

I forrige århundrede begyndte man at udføre boringer, som skulle forsyne København med drikkevand, og boringer og anlægsarbejder som Havnegadetunnelen, Frihavnen og Sydhavnen gav med tiden stadig flere og mere præcise oplysninger om de geologiske forhold.

Der er i årenes løb udført mere end 3000 boringer i København, men de fleste af disse er ikke ret dybe, og boreprøverne er i mange tilfælde mindre gode. De senere års unders $\emptyset$ gelser for en københavnsk undergrundsbane, Citybanen, for lufthavnsudvidelser på Amager og Saltholm og for en fast forbindelse til Malmø m.m., har givet mange geologiske oplysninger. En del af det nye materiale er tidligere publiceret i Bahnson (1973), Bahnson et al. (1969, 1970, 1971, 1972), Bahnson \& Stenestad (1970), Bang \& Stenestad (1970a, 1970b), Larsen (1965, 1966, 1969), Mertz et al. (1969) og Stenestad (1974). Der findes desuden nogle populære oversigtsartikler om Københavns geologi i f.eks. Rosenkrantz (1955), Sorgenfrei (1959), Heller (1973) og Stenestad (1973 b).

Formålet med den foreliggende publikation er, især på grundlag af citybaneundersøgelsen, at give en geologisk beskrivelse af Københavnsområdet. Det geografiske område, der beskrives, omfatter Den indre by, Østerbro og Christianshavn samt dele af Nørrebro, Frederiksberg, Vesterbro og Amager. Områdets afgrænsning fremgår af kortet, fig. 1. Desuden omtales forholdene på Saltholm og i de tilgrænsende dele af Øresund (fig. 3). Den del af lagserien, der omtales, tilhører i aldersmæssig henseende øvre kridt, ældre tertiær og kvartær. Stratigrafi, bjergarter og lagtykkelser er vist i skematisk form i fig. 34. 


\section{Tidligere geologiske undersøgelser i København}

De dele af byen, som beskrives i denne afhandling, er til dels behandlet i en række ældre publikationer, som dog især omhandler den øverste del af den prækvartære lagserie i områder langs Københavns havn, fra Sydhavnen til Svanemøllen.

I litteraturlisten er anført en del af de værker, som har haft betydning for opfattelsen af områdets geologi. Det vil føre for vidt at give et fuldstændigt referat af den ældre litteratur, og her skal blot anføres nogle få eksempler.

Forchhammer omtaler Nyholmboringen (1843a), den sjællandske kridtformation (1843b) og det nyere kridt (1849, 1861).

Johnstrup omtaler grønsandslagene ved Vestre Gasværk (1872) og grønsandet på Sjælland (1876).

Von Koenen (1885) beskriver en paleocæn fauna fra grønsandslagene ved Vestre Gasværk.

Ambt og Schønheyder (1888) giver en oversigt over de af vandværket i 1886-87 udførte unders $\varnothing$ gelsesboringer i Københavns omegn. Beretningen er bilagt kort i 1: 80000 over vandrejsningen og kalkens beliggenhed.

Rosenkjær (1896 p. 272 f.) beretter om danienkalk og grønsandslag fra Frihavnens bund.

Rørdam gav i 1897 en oversigt over de sjællandske maastrichtien-, danienog selandienbjergarter og udgav de geologiske kortblade København og Roskilde i 1899. Heri findes et kort over prækvartæroverfladens bjergarter (Rørdam 1899, fig. 1) og et højdekort over prækvartæroverfladen (Rørdam 1899, tavle II). Rørdam tvivlede på, at grønsandslagene ved Vestre Gasværk var faststående tertiæraflejringer (Rørdam 1899, p.38).

Grönwall (1904) behandler ligeledes lagserien ved Vestre Gasværk og når til den opfattelse, at grønsandslagene er faststående. Det famøse »gruslag « mellem grønsandslagene og danienkalken, som er årsagen til Rørdams tvivl, er, ifølge Grönwall (1904, p.46) en løs, grå, meget glaukonitholdig mergel med et ubetydeligt indhold af fremmedelementer, sandkorn, småsten, mørtel, glas, stenkul og slagge.

Brünnich Nielsen (1910) beskriver en fauna fra blokke af danienkalk, opgravet ved havneuddybningen ved Knippelsbro i 1909. Han sammenligner med tilsvarende forekomster og finder, at kalken er yngre end danienkalken 
og ældre end det paleocæne echinodermkonglomerat. ved Vestre Gasværk.

Bonnesen, Bøggild og Ravn (1913) fremlægger resultaterne fra Carlsbergfondets dybdeboring i Grøndalseng 1894-1907, der nåede gennem skrivekridtet og standsede $\mathrm{i}$ en dybde af ca. $860 \mathrm{~m}$ i kalksten af campanien alder. Grøndalsboringen er stadig den dybeste boring i København.

Rosenkrantz (1920a) omtaler havneudgravningerne i Sydhavnen og beskriver profiler og bjergarter fra danien-selandien grænsen. Fossilindholdet beskrives indgående, og der gives en oversigt over lokaliteter i Københavnsområdet, som sættes i relation til lokaliteter omkring Malmø, Køge og Grenå. » $\varnothing$ vre craniakalk « tolkes som de paleocæne mergellags bundkonglomerat.

Rosenkrantz (1920b) og Harder (1922) beskriver bl.a. grønsandslagene ved Sundkrogen (Svanemøllen).

Rosenkrantz ydede i de næste 40 år en lang række bidrag til belysningen af det æeldre paleocæn (danien og selandien). Blandt disse afhandlinger bør nævnes oversigten over de københavnske grønsandslag i Sundkrog- og Vestre Gasværkområderne med en diskussion af det danske paleocæn (1924a), undergrundens tektoniske forhold i København og nærmeste omegn (1925), der bl.a. indeholder omtale af en række vigtige lokaliteter, hvoriblandt Nyholmboringen, og endelig en meget grundig rapport om en videnskabelig udgravning af selandienlagserien ved Vestre Gasværk i forbindelse med dettes nedrivning (1930). Derpå kom nogle afhandlinger om stratigrafi og tektonik i det østsjællandske danien (1931, 1934, 1937).

Milthers' anden udgave af Nordøstsjællands Geologi (1935) giver en oversigt over kvartær- og prækvartærlagene i København. Heri omtales bl.a. Havnegadetunnelen (Milthers 1935, pp. 19-20) og de københavnske moræneaflejringer med to tydelige morænelersenheder (Milthers 1935, p.58).

Gry (1935) gennemgår 15 paleocænlokaliteter i Københavnsområdet og giver en petrografisk beskrivelse af bjergarterne, som inddeles i bjergartstyper, der på lovmæssig måde går over i hinanden. Han demonstrerer lagseriernes relation til de underliggende bjergarter og finder heri forklaringen på, at København har sandet paleocæn (selandien) på kalksand (danien).

Rosenkrantz (1955) giver en oversigt over problemerne omkring Københavns klippegrund og trafikproblemer, og Sorgenfrei (1959) giver et kortfattet, ajourført overblik over Københavnsegnens dybgrund, hvori han bl.a. omtaler forkastninger i Svanemøllebugten.

De ovennævnte tidligere undersøgelser havde ført til den opfattelse, at prækvartærlagene var opdelt i kilometerstore blokke, som hver for sig indeholdt større eller mindre dele af kridt-tertiær lagserien. Man vidste, at kridtets overflade i området øst for Rosenkrantz' Carlsberg-forkastning (Rosenkrantz 1937) lå ca. $100 \mathrm{~m}$ under havoverfladen, således i kote $\div 110 \mathrm{~m}$ på Orlovsværf- 
tet (Nyholm boringen, Rosenkrantz 1925) og i kote $\div 121$ m ved Amtssygehuset i Gentofte (Rosenkrantz 1937). Kridtet overlejredes af ca. $100 \mathrm{~m}$ kalksten fra danien, nederst væsentligst bryozokalk og derover kalksand (Rosenkrantz 1937). Den øvre del af danienkalken, som man kendte fra udgravninger og tunneler, var tydeligt bænket, med vekslende hårde og bløde lag og med sammenhængende, gennemgående flintlag. Stedvis forekom sprækkezoner. Danienlagene blev overlejret af glaukonitiske kalk-, sand- og mergelaflejringer fra selandien (Rosenkrantz 1924 a). Ved København havde selandienaflejringerne været mere end 6 m mægtige (Vestre Gasværk: 6,6 m, Sundkrogen: 6,1 m (Gry 1935, p. 19, 21)), men de var over store strækninger borteroderet af istidens gletschere og smeltevandsstrømme og fandtes idag dels i mindre områder langs havnen, dels i to større sammenhængende områder, et mellem Sydhavnen og Søerne og et ved Øresundskysten (Rosenkrantz 1937, 1955). Prækvartæroverfladen var afhøvlet af istidens gletschere, der havde efterladt skurestriber i kalkoverfladen og en moræneaflejring, bestående af to morænelersenheder, af hvilke den nederste kunne indeholde oparbejdede interglaciale jordlag, f.eks. de såkaldte rav-pindelag, kendt fra Frihavnen og Valby Bakke (Milthers 1935). Ifølge bl.a. det citerede værk måtte man vente postglaciale, marine lag i store områder langs havnen, således i hovedparten af det område, den planlagte citybane skulle gennemløbe. 


\section{Citybaneboringerne 1967-1972}

Siden begyndelsen af 1940erne var der udført omfattende skitseprojekterings-, kommissions- og udvalgsarbejder angående anlæg af tunnelbaner i København (Mølgaard 1974). I 1961 nedsatte ministeren for offentlige arbejder et tunnelbaneudvalg, som i slutningen af 1964 afgav betænkning. Efter to års behandling i folketinget kom Citybaneloven af juni 1967, en anlægslov for en dobbeltsporet S-bane i tunnel fra Dybbølsbro via Hovedbanegården, Højbro, Kgs. Nytorv til Østerport station med tilslutning til de bestående S-baner ved såvel Dybbølsbro som Østerport. Lovens ordlyd gav i nogen grad løsningen på linieføring og stationsplacering, men længdeprofilet var ikke på forhånd fastlagt, idet der ikke var taget stilling til, om tunnelen skulle placeres lige under terrænoverfladen, eller om den skulle udføres dybtliggende ved tunnelering i kalken.

Projekteringsarbejdet blev indledt med forslag til en højtliggende tunnelbane, beliggende ca. $10 \mathrm{~m}$ under gadeoverfladen. Borearbejdet, der blev forestået af Geoteknisk Institut (DGI), blev påbegyndt i efteråret 1967. Der udførtes i princippet en undersøgelsesboring for hver $50 \mathrm{~m}$ langs borelinien, men der blev derudover udført et antal pejleboringer. Ialt blev der udført 205 boringer, af hvilke størstedelen er geotekniske undersøgelsesboringer. I de kvartære lag anvendtes dels traditionel boreteknik (tørboring med optagning af intakte prøver) dels kerneboring. Boringerne i prækvartærlagene blev udført som kerneboringer med kontinuerlig prøveoptagning i dobbelt kernerør.

Da man regnede med, at citybanens tunnel på strækningen Ingerslevsgade - Rådhuspladsen væsentligst skulle lægges i kvartærlagene, borede man ikke så dybt på denne strækning. Man ville blot være sikker på at kende hele den kvartære lagserie inclusive eventuelle større flager af København Kalk.

Den næste etape af borearbejdet gik fra Rådhuspladsen igennem det ældste København til Vandkunsten og Gammel Strand og videre til Højbro Plads. På denne strækning kunne tunnelen med fordel tænkes lagt i prækvartærlagene. For det første ville man stå frit med hensyn til valg af linieføring, i modsætning til hvad der er tilfældet ved en højtliggende tunnel, som er afhængig af det eksisterende gadenet. For det andet ville risikoen for skader på bygninger $\mathrm{i}$ Den indre by, der står på tykke fyldlag, være mindre ved en dybtliggende 
tunnel, og for det tredie kunne man tage hensyn til det forhold, at en eventuel tunnel til Amager gennem denne del af byen, som påpeget af Rosenkrantz (1955), under alle omstændigheder måtte lægges i kalken, idet havnens bund praktisk taget er sammenfaldende med kalkoverfladen i dette område.

I løbet af 1968 blev det klart, at generne for bytrafikken og byfunktionerne $\mathrm{i}$ byggetiden ville blive af et sådant omfang, at en dybtliggende tunnel måtte tages op til nærmere overvejelse, og i foråret 1970 afgav DSB en redegørelse og indstilling til ministeren, ifølge hvilken man måtte anbefale en tunnel i kalken.

Som følge af disse overvejelser blev det ønskeligt at bore noget dybere, og nogle af boringerne blev herefter ført et stykke ned i bryozokalken.

De sidste etaper af boreprogrammet omfattede strækningerne fra Højbro Plads til Østerport. Der udførtes desuden nogle supplerende boringer på tidligere undersøgte strækninger samt nogle specialundersøgelser, dels Svanemølleundersøgelsen, der omtales i områdebeskrivelsen, og dels uddybningen af boringen TUBA 13 ved Hovedbanegården til kote $\div 125 \mathrm{~m}$ (se fig. 1 og 5). Den nåede herved igennem hele danienlagserien og ca. $20 \mathrm{~m}$ ned i kridtlagene. Da den er den hidtil eneste boring i København, fra hvilken der foreligger en ubrudt række af borekerner repræsenterende hele danien og den $\emptyset$ verste del af maastrichtien, har den betydelig geologisk interesse. Den har givet anledning til nogle videregående studier af nogle danienkalktyper (Nielsen 1976) og af hvilesporer af dinoflagellater (Hansen, in prep.). TUBA 13 er desuden valgt til typelokalitet for København Kalk, der defineres som formation i denne afhandling.

Citybaneundersøgelsen kom især til at beskæftige sig med København Kalken og de kvartære lag. Ganske vist blev en del boringer ført ned i toppen af bryozokalkserien, men kun i TUBA 13 blev den gennemboret. De efterfølgende beskrivelser kommer derfor til at omfatte hele den københavnske lagserie fra kridt til fyld, men med særlig vægt lagt på København Kalken. 


\section{Materiale}

\section{Citybaneboringerne}

Fra de ovenfor omtalte 205 boringer for citybanen forelå der et meget betydeligt antal boreprøver, ikke mindst i form af kerneprøver fra prækvartærlagene. 56 boringer stoppede i de kvartære aflejringer, 126 nåede ned i kalksandskalken, og 23 blev ført gennem kalksandskalken ned i bryozokalken. En boring, TUBA 13, blev ført gennem hele danienserien og ned i maastrichtienlagene. Boringernes placering fremgår af lokalitetskortet (fig. 1). Boringerne er tillige opført i kotelisten, tabel 1.

Kotelisten er dels en fortegnelse over de prækvartærboringer, der findes på lokalitetskortet, og som er benyttet ved fremstillingen af kort og profiler, dels er den tænkt som en samling af basisdata, som måske kan komme til nytte ved fremtidige unders $\emptyset$ gelser i området. Den er opstillet efter DGU's borearkivnummer og indeholder koter til vigtige lagflader samt bemærkninger om boringernes beliggenhed eller, for citybaneboringernes vedkommende, arbejdsnummeret (TUBA nr.), som er benyttet i alle tidligere rapporter m.v. om citybanen, og som også benyttes i denne publikation bortset fra kotelisten og lokalitetskortet. Det er imidlertid let at finde det til TUBA nummeret svarende DGU nummer eller omvendt, idet citybaneboringerne er DGU nummereret i samme rækkefølge som TUBA nummereringen.

Citybaneboringerne er, som det vil ses af lokalitetskortet, i overvejende grad placeret nær tunnellinien, d.v.s. i et smalt bælte, der i sydvest-nordøstlig retning går fra området ved Hovedbanegården gennem City til Østerport. Alle de dybe, egentlige undersøgelsesboringer ligger i dette strøg, hvad der vanskeliggør vurderingen af lagstillingen i området, fordi boringerne, set i en lidt større regional sammenhæng, nærmest ligger på en ret linie. Den uheldige virkning heraf forstærkes af det forhold, at laghældningerne i området er ganske små. På den anden side har den store nøjagtighed, med hvilken laggrænserne har kunnet fastlægges, trods alt gjort det muligt at nå visse konklusioner. 


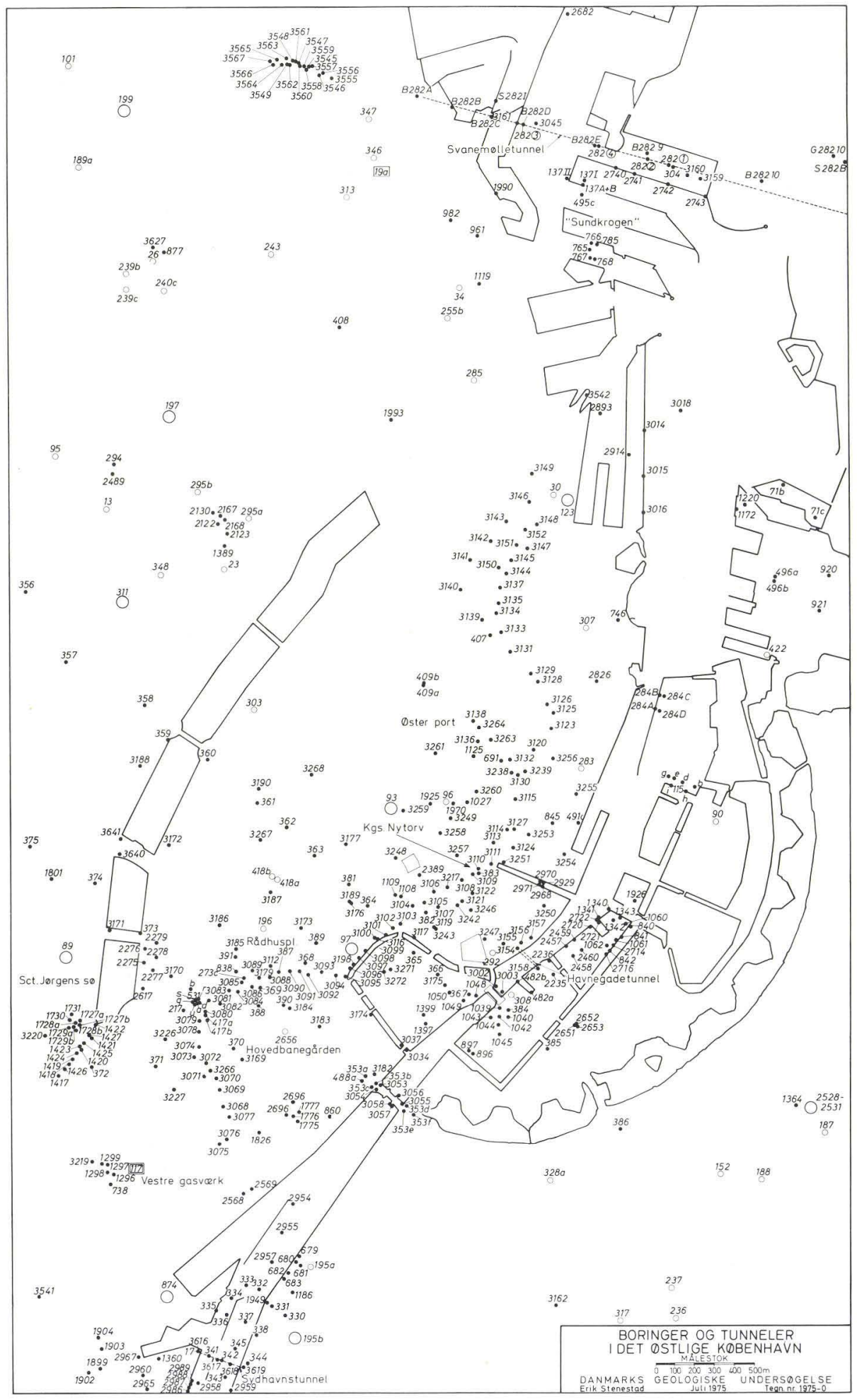




\section{Andre boringer}

Den ovennævnte problemstilling gjorde det ønskeligt at inddrage yderligere materiale i vurderingerne. Boringer af ældre dato opfylder sjældent de krav, man idag stiller til en undersøgelsesboring, og de er som regel også udført med ganske andre formål; men i det foreliggende tilfælde var de et værdifuldt supplement. En særstilling indtager boringerne fra de senere års geotekniske undersøgelser, der er af samme kvalitet som citybaneboringerne. Oplysningerne er især hentet i DGU's borearkiv, men der er tillige indsamlet oplysninger om boringer hos Københavns Havnevæsen og Stadsingeniørens direktorat. Endelig kan det nævnes, at enkelte tidligere publicerede boringer er benyttet, således f.eks. Nyholmboringen og Sundkrogsboringerne. Alle benyttede prækvartærboringer fra undersøgelsesområdet er anført på lokalitetskortet og i kotelisten, tabel 1.

\section{Tunneler og udgravninger}

Der findes i København flere tunnelanlæg, som helt eller delvis forløber i undergrundslagene, og i forbindelse med citybaneundersøgelsen er nogle af disse tunneler blevet undersøgt og opmålt. Det gælder tunnelen i Sydhavnen fra Kalvebod Tværgade til Islands Brygge og tunnelerne i Inderhavnen mellem Havnegade og Christianshavn, medens kloaktunnelen i Svanemøllebugten er studeret på grundlag af ældre oplysninger og enkelte nyere boringer.

Man vidste i forvejen fra udgravninger bl.a. på Saltholm og i Københavns Sydhavn, at København Kalken (i ældre litteratur benævnt Kalksandskalken) er ret rig på flint, der optræder som sammenhængende lag af sædvanligvis 10-20 cm tykkelse. I tunnelerne fik man nu lejlighed til at se, hvorledes ikke blot flintlagene, men også de hårde kalkbænke danner sammenhængende lag, der kan følges over store strækninger, i visse tilfælde flere hundrede meter, hvad der naturligvis er af betydning ved vurderingen af boreresultaterne. De nævnte ældre tunneler er udfort på den måde, at man fra lodrette skakte har fulgt undersiden af en hård kalkbænk eller et flintlag og ladet dette danne tag i tunnelen.

\footnotetext{
Fig. 1: Boringer og tunneler i det østlige København. Boringerne er vist med DGU's borearkivnummer og med en signatur, der angiver lokaliseringens nøjagtighed (sort prik: sikker lokalisering; lille cirkel: mindre sikker lokalisering; stor cirkel: usikker lokalisering (efter adresse eller lignende)). Firkanter og polygoner angiver større udgravninger eller undersøgelsesområder med mange boringer. Boringerne er opfort i kotelisten, tabel 1.

Fig. 1: Drillholes and service tunnels in East Copenhagen. Borings are marked with DGU numbers and symbols indicating accuracy of localization. Squares and polygons indicate major excavations and investigation areas with many boreholes. The borings are listed in table 1.
} 
Det kan til slut nævnes, at der i forbindelse med forskellige større anlægsarbejder, som dels er af ældre dato (f.eks. Sydhavnen, Frihavnen, Vestre Gasværk), dels er udført inden for de senere år (f.eks. Nationalbanken, forskellige rensnings- og kloakeringsanlæg) har været en del udgravninger og byggegruber, i hvilke store profiler har kunnet studeres. Medens der foreligger en ret righoldig litteratur om de ældre anlæg, jf. afsnittet om tidligere undersøgelser, er de nyere lokaliteter endnu kun beskrevet i upublicerede rapporter. De indvundne erfaringer er i muligt omfang taget med i vurderingen af området. 


\section{Metoder}

Kvantitativt udgør boringer fra DGU's arkiver den største del af materialet. For disse boringer foreligger borefirmaernes indberetninger, som bl.a. indeholder en beskrivelse af de gennemborede lag med angivelse af konstaterede laggrænser. Som regel er der tillige indsendt bjergartsprøver, som er beskrevet lithologisk af DGU's geologer. Disse beskrivelser indeholder oplysninger om hovedbjergart, kornstørrelse, farve, hærdningstilstand, øvrige indgående komponenter, herunder fossiler etc., samt en aldersangivelse. Disse oplysninger er benyttet ved udarbejdelsen af tabel 1, som viser koter til udvalgte formationsgrænser.

Da den foreliggende publikation især er baseret på citybaneboringerne, skal der kort gøres rede for de metoder, som blev anvendt ved denne undersøgelse.

Fra kvartærlagene forelå 3 typer af boreprøver: omrørte prøver, optaget med traditionel tørboringsteknik, intakte prøver, optaget ved nedpresning af en cylinder i de uforstyrrede lag under borehullets bund, samt enkelte kerneprøver. Disse prøver blev beskrevet lithologisk efter de ovenfor omtalte retningslinier. Enkelte prøver blev slæmmet på $0,1 \mathrm{~mm}$ sigte og unders øgt under stereomikroskop. Intakte prøver og kerneprøver er særligt egnede ved vurdering af jordlags ægthed (fyldproblemer), lejringsforhold og hærdningstilstand. Omrørte prøver kan undertiden give et mindre pålideligt billede af lagserien. For eksempel kan leret i morænesand og lerfattigt moræneler udvaskes ved borearbejdet, således at disse bjergarter bliver underrepræsenteret i prøverne, fordi de fremtræder som stenet sand.

For prækvartærlagene forelå hovedsagelig kerneprøver, optaget kontinuerligt, således at hele den gennemborede lagserie skulle være repræsenteret i prøvematerialet. Kerneudbyttet kan være større eller mindre end den borede distance. Det kan f.eks. ske, at bjergarten knuses og bortskylles af borevandet, eller at et stykke borekerne ikke kommer op i første omgang. Ved næste kerneoptagning kan det ske, at kernen fra den nye borestrækning og den efterladte kernestump fra den foregående borestrækning kommer op samtidig, hvorved kerneudbyttet (tilsyneladende) bliver større end den borede distance. Ved optegning af det endelige boreprofil fordeles kerneudbyttet således, at kernerne stilles oven på hinanden fra borehullets bund, indtil man 
konstaterer et kernetab. Derefter » hænges kernerne op« ved deres startkote, således at tabet vises i den nederste del af det borede interval. Hvis kernetabet er meget stort og de borede distancer meget lange, bliver usikkerheden på prøvematerialets dybdeplacering tilsvarende stor, og der kan opstå usikkerhed med hensyn til lagseriens udformning i de pågældende intervaller.

Den lithologiske beskrivelse, der blev foretaget på grundfugtige prøver, omfattede en almindelig karakterisering af bjergart, kornstørrelse, farve, m.v., samt en detaljeret opmåling af borekernerne, idet enhver æundring i lithologi, herunder hærdning og sprækkethed, blev registreret. I et vist omfang blev kernerne fotograferet til eksemplificering af geologiske og geotekniske forhold.

Ved prøvebeskrivelsen og bearbejdelsen af de tilvejebragte data benyttedes de traditionelle bjergartsbetegnelser: grønsand, grønsandskalk, kalksandskalk, bryozokalk, slamkalk, kridt, m.fl. Betegnelsen slamkalkrig bryozokalk er benyttet for bryozokalk, hvis indhold af makroskopiske bryozofragmenter udgør en så lille del af kalken, at denne står på grænsen til slamkalk. Det har ved færdiggørelsen af denne publikation været overvejet at erstatte disse betegnelser med mere præcise lithologiske termer, hvad der imidlertid ville medføre, at væsentlige dele af prøvematerialet mătte beskrives påny. De traditionelle betegnelser er derfor bibeholdt. De benyttes her med ren lithologisk betydning og indeholder ingen formations- eller tidsangivelse.

De prækvartære bjergarters hærdningstilstand blev bedømt efter følgende skala: »hårdhed 1《: uhardnet, »hårdhed 2 : svagt hordnet (kan ridses med en negl), »hårdhed 3 «: hordnet (kan skæres med en kniv), »hårdhed 4 : sterkt hardnet (kan ridses med en kniv), »hårdhed 5 «: storkt forkislet/flint (kan ikke ridses med en kniv). Denne klassifikation viste sig praktisk anvendelig ved tolkningen af de geotekniske forsøg. Ved svag forkisling når kalkstenene ikke » hårdhed 5 «. Til støtte for påvisningen af forkislet kalk blev den af Högberg (1971) beskrevne farvningsteknik benyttet på stikprøver af hærdnede kalksten. Det viste sig, at forkislet kalk ofte kan kendes habituelt på en svagt blålighvid farvetone og en rumvægt, som er lavere end for tilsvarende kalcitimprægnerede kalksten.

Ved beskrivelsen af prækvartærprøverne blev der foretaget en kvalitativ bedømmelse af kernernes sprækkethed. Klassifikationen omfattede 5 grupper: »uden sprakker« (store sammenhængende kernestykker), »let sprakket« (ca. 10-15 cm store stykker), »sprakket« (ca. 5-10 cm store stykker), »stcerkt sprakket« (ca. 2-5 cm store brokker) og »knust« materiale.

Ved prøvebeskrivelsen blev der udtaget prøver på ca. 50-100 g af de prækvartære bjergarter til brug ved en biostratigrafisk inddeling af lagserien. Prøverne blev udtaget af uhærdnede eller svagt hærdnede lag, og det blev 
bemærket i prøvebeskrivelsen, om materialet hidrørte fra gravegange eller fra kerneafsnit, som viste andre tegn på forstyrrelse af lagene, idet sammenblanding af yngre og ældre sedimenter kan give problemer ved tolkningen af faunabilledet. Efter slæmning på $0,063 \mathrm{~mm}$ sigte blev slæmmeresten tørsigtet på $1 \mathrm{~mm}$ sigte og bromoformfraktioneret (Vf. 2). Den tunge fraktion blev undersøgt for benthoniske foraminiferer og den lette fraktion for planktoniske foraminiferer. Foraminiferfaunaerne blev unders $ø g t$ under stereomikroskop. Ved studiet af visse detaljer benyttedes scanning elektron mikroskop (SEM). Resultaterne af foraminiferundersøgelsen er anført i Bahnson et al. (1969, 1970, 1971, 1972), Bang og Stenestad (1970a, 1970b) og Mertz et al. (1969). En del af resultaterne er tillige citeret heri, fig. 11-20 og 37.

Samtidig med prøvebeskrivelsen blev der udtaget prøver til geotekniske laboratorieforsøg. Der blev udført bestemmelser af vandindhold, rumvægt, poretal, kornrumvægt, kalkindhold og glødetab, samt for kvartært materiale desuden tæthedsindeks og kornfordelingskurver. Med intakte prøver af kvartært materiale og af kalk er udført styrke- og deformationsforsøg. Resultaterne af disse undersøgelser, som ikke skal refereres her, findes i de geotekniske rapporter fra citybaneundersøgelsen (Geoteknisk Institut 1969a, 1970a,b,c, 1971 a,b, 1972a,b, 1973a,b).

Den geologiske beskrivelse af kvartærlagene blev udført af E.L. Mertz og Henner Bahnson. Prækvartærlagene blev beskrevet af forfatteren, i den sidste del af unders $\emptyset$ gelsesperioden med assistance af Hans Henning Jensen. Den biostratigrafiske undersøgelse blev foretaget af Inger Bang med bistand af et vekslende antal assistenter. Alle de nævnte har medvirket ved udarbejdelsen af de geologiske rapporter. Koordinationen af arbejdet og redigeringen af de geologiske rapporter blev varetaget af forfatteren. 


\section{Lithologi og stratigrafi}

\section{Maastrichtien}

Maastrichtien etagen er i Københavnsområdet repræsenteret ved kridtlag tilhørende en formationel enhed, som her informelt betegnes kridtenheden. Formationens øvre grænse er fastlagt ved bunden af fiskeleret på Stevns. Den nedre grænse er ikke fastlagt. Fra dybe boringer mange steder i Danmark, bl.a. boringerne efter gas og olie, ved man, at kridtlagene nedefter gradvist går over i mergeler og kalksten. Oplysninger om det københavnske kridt er tidligere publiceret fra Nyholmboringen (Rosenkrantz 1925) og fra Grøndalsboringen (Bonnesen, Bøggild og Ravn 1913), som giver det foreløbigt mest komplette profil igennem kridtenheden på Københavnsegnen. Der foreligger desuden nogle oplysninger om kridtlagene i Øresund og på Saltholm (Larsen 1967, Stenestad 1975).

En af citybaneboringerne, TUBA 13 ved Hovedbanegården, er ført ca. 22 m ned i kridt af maastrichtien alder (tabel 2). Den $\varnothing v$ re del af kridtet i TUBA 13 er hvidt, blødt og afsmittende. Nedefter optræder lag, linser og slirer af mergelagtigt kridt, og under kote $\div 118 \mathrm{~m}$, ca. $15 \mathrm{~m}$ under kridtoverfladen, er kridtet udviklet i »Bänderkreide«facies (Voigt \& Häntzschel 1956), d.v.s. præget af gravegange tilhørende ichnogenus Thalassinoides og Zoophycos (Voigt \& Häntzschel 1956, Bromley 1967, Håkansson et al. 1974). Gravegangene er velbevarede og viser derved, at de pågældende lag ikke er omlejrede eller forstyrrede efter gravegangenes dannelse.

Ved kote $\div 119,3 \mathrm{~m}$ findes et ca. $5 \mathrm{~cm}$ tykt lag af mergelagtigt kridt med ca. $1 \mathrm{~cm}$ store, skarpkantede, delvis itubrudte kridtbrokker og med små, uregelmæssige linser af kridtslam (fig. 2). Laget opfattes som en slump bed, dannet ved skred på havbunden. Sådanne skred må have forårsaget en vis erosion og omlejring af de $\varnothing$ vre kridtlag. I det viste eksempel er der grund til at tro, at transportvejen har været relativ kort, idet de svagt hærdnede kridtbrokker er skarpkantede og gennemsprækkede. Slumping i kridt er bl.a. beskrevet fra Rügen (Steinich 1967, »frühdiagenetische Gleitungen«) og fra Normandiet (Kennedy \& Juignet 1974). Ifølge den model Håkansson et al. (1974 p.229) opstiller på basis af Wolfe (1968), ophører slumping og sediment flow inden afslutningen af den tidlig-diagenetiske fase.

Kridtet i TUBA 13 er overvejende hærdnet eller svagt hærdnet, men der 


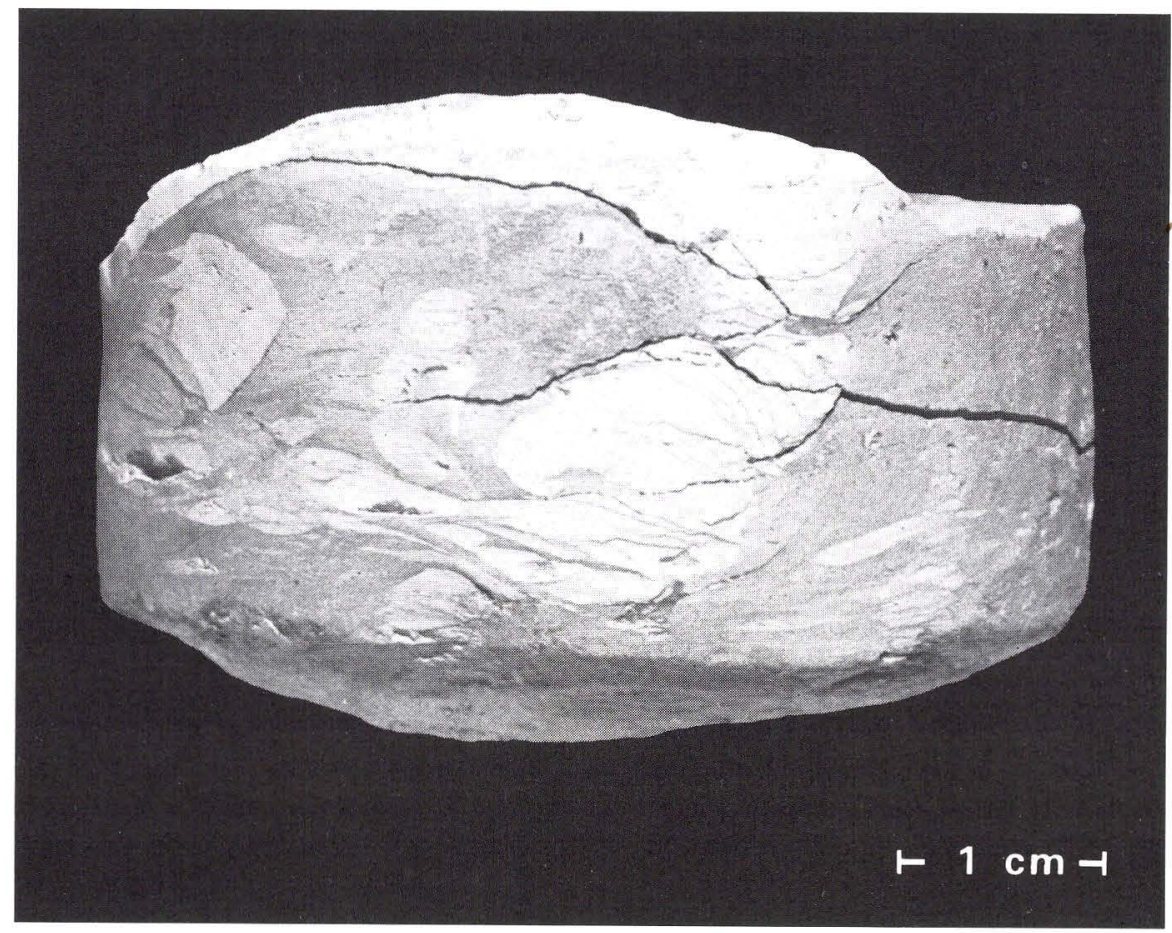

Fig. 2: Mergelagtigt kridt med skarpkantede, delvis itubrudte kridtbrokker og med uregelmæssige linser af kridtslam, der tolkes som et resultat af slumping. Boring TUBA 13 (DGU 201.3080), prøve 133, 225-230 cm under top af kernen, kote $\div 119,3 \mathrm{~m}$. O. Neergaard Rasmussen foto. Fig. 2: Marly chalk with angular, partly broken lumps of white chalk and with irregular lenses of limemud, probably formed by slumping. Borehole TUBA 13 (DGU 201.3080), sample No. 133, 225-230 cm below top of core, $119.3 \mathrm{~m}$ below sea-level. Photograph by O. Neergaard Rasmussen.

forekommer også mindre partier af blødt, uhærdnet kridtslam og af stærkt hærdnet, pletvis forkislet kridt. Flint optræder kun i mindre mængder i kridtlagene i TUBA 13. Flinten er mange steder grå, men sort flint forekommer også. I Nyholmboringen benyttede Rosenkrantz (1925) forskelle i hærdning og flintindhold til at trække grænsen mellem maastrichtien og danien. Grænsen blev lagt ved et knæk på arbejdskurven i kote ca. $\div 110 \mathrm{~m}$. Under denne dybde gik borearbejdet hurtigere, og der boredes $\mathrm{i} \gg$ meget lys kalk « med et - i forhold til den overliggende kalk - ubetydeligt indhold af flint. Flinten var af den sorte, glansfulde type, som Rosenkrantz anså for karakteristisk for kridtet. Fra boringer på og ved Saltholm vides, at kridtet også der er hærdnet - svagt hærdnet og flintfattigt (Larsen 1967, Stenestad 1975). I Saltholm bor. 11 (fig. 3), hvor der blev truffet kridt fra 56,8 $\mathrm{m}$ til slutdybden 


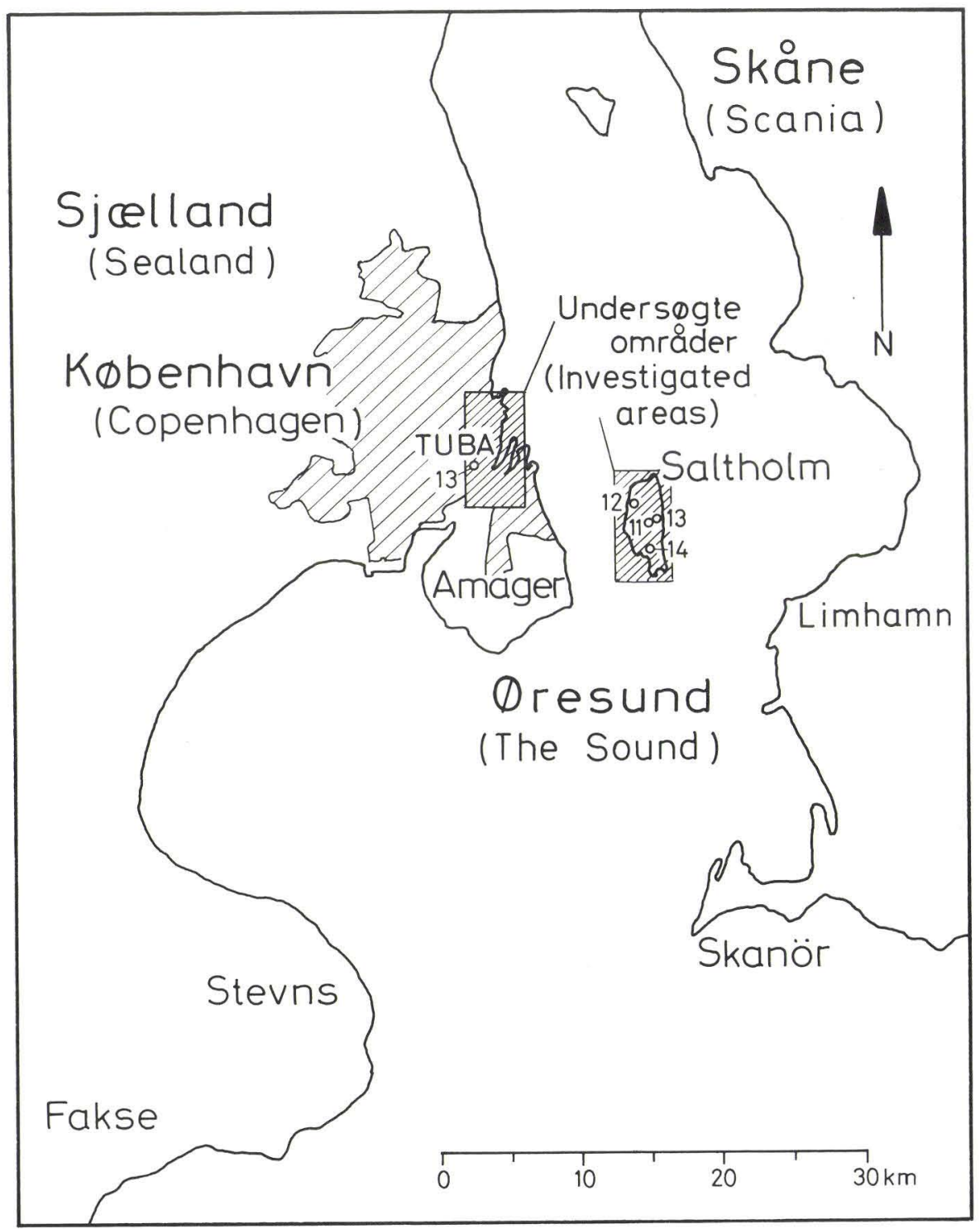

Fig. 3: Kort visende beliggenheden af undersøgelsesområdet, boringen TUBA 13 og Saltholmboringerne 11-14.

Fig. 3: Map showing location of the investigation area, the borehole TUBA 13 and the island of Saltholm with boreholes 11-14.

77,3 m under terræn, er kridtet tydeligt bioturberet. Det indeholder slirer af sort, afsmittende ler samt en del åbne sprækker og glideflader med harniske. Nederst i profilet findes små mængder glaukonit. 
Kridtet i TUBA 13 er af øvre maastrichtien alder og tilhører næsten udelukkende Pseudotextularia elegans zonen. Den nederste del af kridtet når dog ned i Pseudouvigerina rugosa zonen (Stenestad 1971b pp. 55-56, 1973c pp. 90-91). Kridtet i Saltholmboringerne er ligeledes af øvre maastrichtien alder.

\section{Maastrichtien-danien grænsen}

Som det er velkendt, findes der på Stevns en hærdningshorisont af ældre danien alder, hvori indgår cerithiumkalk, fiskeler og dele af gråkridtet (Rosenkrantz 1925b og senere). Brotzen (1959 p. 19) korrellerer en hærdningshorisont (DA 4) i bunden af danienlagserien i Limhamn med den nævnte hærdningshorisont på Stevns. Ødum (1971) kan ikke påvise et tilsvarende hærdningslag i Skanörboringerne. I de ældre boringer 101-104 i Øresund omkring Saltholm (Larsen 1967) er den øverste del af kridtlagene overvejende stærkt hærdnet og indeholder gange, udfyldt af materiale fra de overliggende danienbjergarter. Udformningen af maastrichtien-danien grænsen varierer således en del i Øresundsregionen mellem Stevns, København, Limhamn og Skanör.

I citybaneboring TUBA 13 findes maastrichtien-danien grænsen i kote : 103,45 m ved overkanten af en hærdningshorisont, bestående af stærkt hærdnet kalksten (slamkalk/kridt) med stejle kalcitfyldte sprækker, med store glaukonitpletter og med talrige uregelmæssige gravegange, som indeholder et ret groft, glaukonitpræget kalkmateriale med en foraminiferfauna, som if $\varnothing$ lge Bang (In: Mertz et al. 1969) er af danien alder og er den samme som den, der findes i den nedre del af bryozokalken på Stevns. Under den stærkt hærdnede kalksten findes svagt hærdnet kridt med stærkt hærdnede partier og glaukonitfyldte hulrum. Kridtet er af øvre maastrichtien alder, zonen med Pseudotextularia elegans (Rzehak), som i Danmark er begrænset til det alleryngste maastrichtien (Stenestad 1971b pp. 55-56). Over hærdningshorisonten følger en serie af svagt glaukonitiske kalksten med en ren danien foraminiferfauna. Den for cerithiumkalken på Stevns karakteristiske foraminiferfauna er ikke tilstede (Bang, pers. medd.). Hærdningshorisonten, som markerer kridtets erosionsoverflade, er en hardground (sensu Bromley 1967 p. 157). Som omtalt af Håkansson et al. (1974 p. 226), er hardgrounds dannet, hvor der har været en afbrydelse af sedimentationen, og de findes både fuldt udviklede og $\mathrm{i}$ forskellige stadier af hærdning. De er et havbundsfænomen og er ikke specielt knyttet til littoralfacies.

På Saltholm viser de fire nye boringer (fig. 3) følgende udformning af maastrichtien-danien grænsen: I boring $1 /$ er de $\varnothing v e r s t e ~ 35 \mathrm{~cm}$ af kridtlagene 


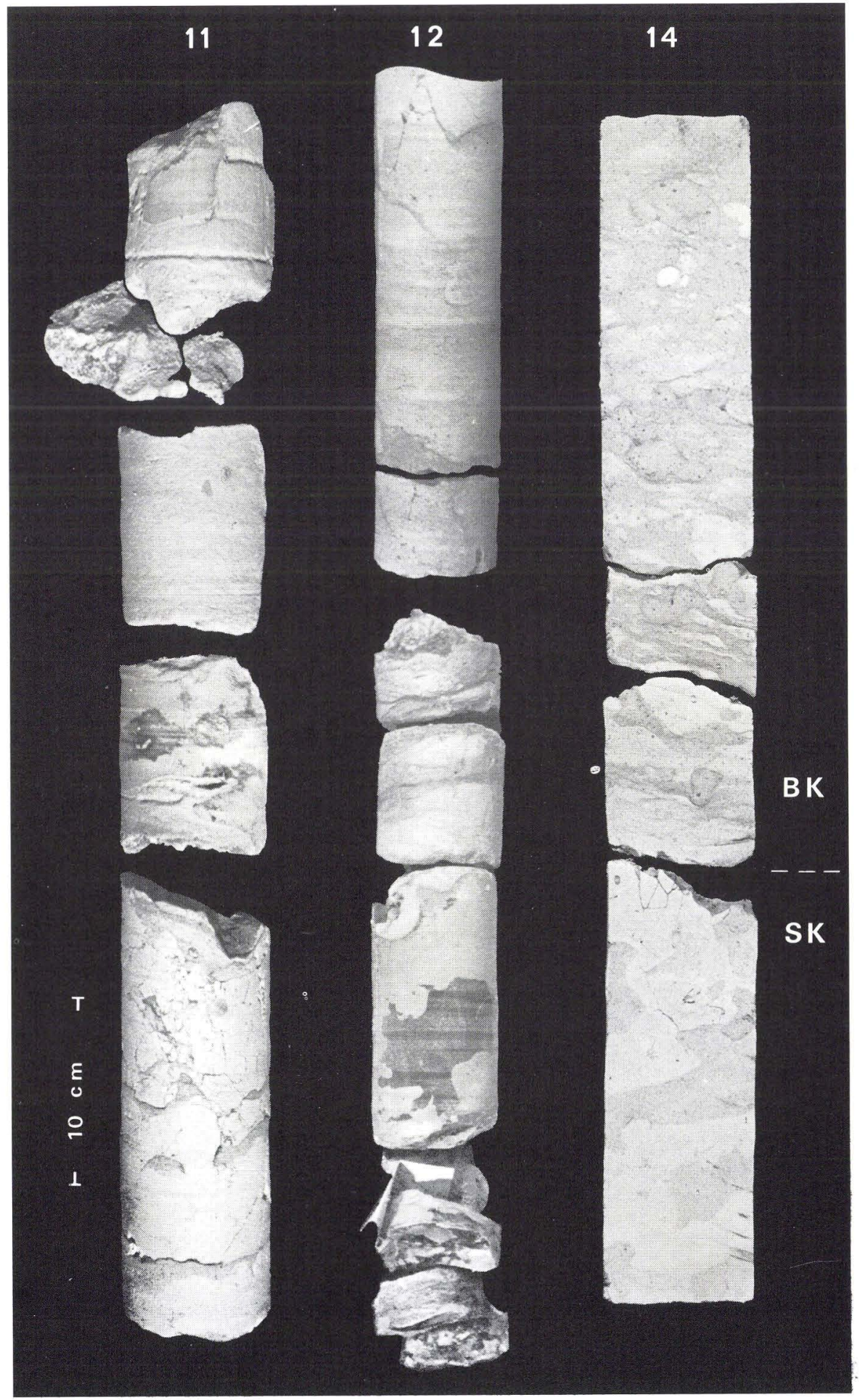


hærdnede og breccierede, og der forekommer små stylolitsømme. Kridtet indeholder desuden gravegange, som er udfyldt af stærkt hærdnet bryozokalk (fig. 4). Derunder følger kridt, som er overvejende svagt hærdnet, med enkelte forkislede partier. Det indeholder ligeledes gravegange, som er udfyldt af glaukonitisk, hærdnet eller forkislet bryozokalk, og som i denne boring når 170-185 cm ned under kridtoverfladen. Kridtet overlejres af svagt hærdnet bryozokalk, af danien alder, med et indhold af glaukonit og ler, som hurtigt aftager opefter. I boring 12 findes maastrichtien-danien grænsen 66,85 $\mathrm{m}$ under terræn ved oversiden af et lag, bestående af flint og forkislet kridt, hvori der findes svagt hærdnede kridtpartier (fig. 4). Oversiden af dette lag er uregelmæssigt grubet og har været udsat for erosion, inden danienlagene blev afsat. Forkisling og flintdannelse har først fundet sted på et senere tidspunkt. Under det forkislede lag findes svagt hærdnet kridt med gravegange, bl.a. Thalassinoides, samt en ren maastrichtien foraminiferfauna. Over det forkislede lag findes et $15 \mathrm{~cm}$ tykt, konglomeratisk udseende lag af glaukonitisk slamkalk med mergelslirer og kridtboller, antagelig dannet ved slumping. Det er gennemsat af gravegange og indeholder mikrostyloliter. Det overlejres af en bryozokalkserie, af hvilken de nederste $65 \mathrm{~cm}$ er udviklet som en skalfragmentrig slamkalk med glaukonitisk gravegangsmateriale og stedvise forkislinger. I boring 13 er prøverne på maastrichtien-danien grænsen sprækkede og knust. I boring 14 viser foraminiferfaunaerne, at maastrichtien-danien grænsen findes $\mathrm{i}$ en serie af svagt glaukonitiske kalksten 65,3-66,4 m under terræn. Den nøjagtige beliggenhed inden for dette interval har endnu ikke kunnet fastslås. Ved sammenligning med de øvrige boringer (Saltholm 11 , 12), forekommer det mest sandsynligt, at grænsen findes øverst i det nævnte interval, ved overkanten af en hvid, overvejende stærkt hærdnet og let breccieret kalksten (fig. 4), som underlejres af kalksten med lerede slirer og gravegange, udfyldt af glaukonitisk og bryozoholdigt kalkmateriale. Over den hvide kalk findes grålig bryozokalk, som er præget af slumping. Den indeholder en foraminiferfauna, som er karakteristisk for cerithiumkalken på Stevns (Bang, pers. medd.).

Af det anførte fremgår følgende: I citybaneboring TUBA 13 og Saltholmboringerne 11, 12 og antagelig 14 er maastrichtien-danien grænsen markeret af en sedimentationsafbrydelse. Den øverste del af kridtet er udviklet som en

Fig. 4: Grænsen mellem maastrichtien og danien i Saltholmboringerne nr. 11, 12 og 14. Bioturberet (Thalassinoides), hærdnet og breccieret kridt (SK) overlejres diskordant af lerede slamkalksten (BK), som er bioturberet og delvis præget af slumping. O. Neergaard Rasmussen foto. Fig. 4: The Maastrichtian-Danian boundary in Saltholm boreholes Nos. 11, 12 and 14. Bioturbated (Thalassinoides), indurated and fractured white chalk (SK) is discordantly overlain by clayey calcilutites, which is bioturbated and to some extent demonstrate slump structures. Photograph by O. Neergaard Rasmussen. 
hardground med gravegange, udfyldt af glaukonitisk kalkmateriale fra de overliggende danienlag. Denne hardground er i TUBA 13 gennemsat af kalcitfyldte sprækker, og i Saltholmboringerne 11, 13 og 14 er den breccieret og kalcitcementeret. I Saltholmboringerne 12 og 14 viser den nederste del af danienlagene tegn på slumping. I boring $12 \mathrm{er}$ der to sedimentationsafbrydelser nederst i danienlagene, dels $15 \mathrm{~cm}$ over maastrichtien-danien grænsen ved overkanten af det konglomeratisk udseende lag af glaukonitsk slamkalk, dels $80 \mathrm{~cm}$ over maastrichtien-danien grænsen ved overkanten af den skalfragmentrige slamkalk.

De nævnte observationer viser, at også Københavnsområdet blev berørt af den generelle regression ved maastrichtien-danien grænsen. Detaljerne i udformningen af lagserierne viser, at der ikke blot i Øresundsregionen som helhed, men også inden for et mindre delområde, Københavnsområdet, har været noget varierende lokale forhold.

\section{Danien}

Lag af danien alder findes i alle dele af Københavnsområdet.

Rørdam (1897) omtaler 5 hovedbjergartstyper fra danien: Koralkalk, bryozokalk, foraminiferkalk, coccolithkalk og spongiekalk. Koralkalk kendtes ikke faststående fra København, men de øvrige kalktyper var repræsenteret. Bryozokalk blev beskrevet fra Frederiksholms kalkbrud (i Sydhavnen) og fra Gl. Carlsberg. Foraminiferkalk fandt Rørdam bl.a. ved Østre Gasværk og i bunden af Frihavnen. Coccolithkalk blev fundet faststående på Saltholm, øverst i profilerne i de nedlagte kalkbrud på den nordlige del af øen. Spongiekalk dannede et tyndt dække over foraminiferkalk i Københavns havn ud for Larsens Plads. Af fundstederne kan man slutte, at Rørdams bryozokalk stratigrafisk hidrører fra den nederste afdeling af danienlagserien, som vest for Carlsberg forkastningen danner den prækvartære overflade, medens de $\emptyset$ vrige kalktyper alle hidrører fra den øverste afdeling af danienlagserien. Rørdams petrografiske typer kan ikke med sikkerhed genkendes makroskopisk. Ved den lithologiske beskrivelse af danienkalkstenene fra citybaneboringerne viste det sig hensigtsmæssigt at inddele kalken i 3 hovedtyper: Kalksandskalk, bryozokalk og slamkalk (Larsen 1961, pp. 18-19).

Rosenkrantz (1937) opdelte danienets aflejringer i 3 formationelle enheder, adskilt af abrasionsflader. Denne hovedopdeling blev bibeholdt af Sorgenfrei (1957). Den nederste enhed består af cerithiumkalken og fiskeleret ved Stevns Klint. Den mellemste enhed omfatter koralkalken ved Fakse samt bryozokalk med indslag af slamkalk og med glaukonitiske niveauer, i Østsjæl- 
land og Nordjylland. Den øverste enhed omfatter kalksandskalk og coccolithkalk i de samme områder samt gruskalken ved Herfølge.

Ved beskrivelsen af citybaneboringernes danien kunne der skelnes mellem en $\emptyset$ vre afdeling, som fortrinsvis bestod af kalksandskalk, og en nedre afdeling, som bestod af vekslende lagfølger af bryozokalk og slamkalk. De to afdelinger kan indpasses som mellemste og øverste enhed i den ovennævnte tredeling af danien. Den nederste formationelle enhed er ikke påvist i København (TUBA 13). men cr muligvis tilstede i boring 14 på Saltholm (Se: Maastrichtien-danien grænsen). De to københavnske formationelle enheder, kalksandskalkenheden og bryozokalkenheden, vil i det følgende blive omtalt hver for sig. Kalksandskalkenheden, der ved citybaneundersøgelsen blev særlig godt kendt, defineres som København Kalk Formationen.

\section{Bryozokalkenheden}

22 af citybaneboringerne blev ført nogle meter ned i den øverste del af bryozokalkenheden. Kun én boring, TUBA 13, nåede gennem hele enheden. Materialet er således endnu for ufuldkomment til, at der kan gives en tilfredsstillende beskrivelse af den vertikale og horisontale variation. Af denne grund kan bryozokalkenheden ikke defineres som en formel formation.

I TUBA 13 (fig. 5 og tabel 2) henføres afsnittet $\div 50,25-\div 103,45 \mathrm{~m}$ til bryozokalkenheden. Den nedre grænse er, som ovenfor omtalt, placeret ved overkanten af en hardground. Lagserien består hovedsagelig af slamkalk og slamkalkrige bryozokalksten. Bryozokalk findes i intervallerne $\div 50,3-\div$ $64,0 \mathrm{~m} \mathrm{og} \div 80,7-\div 97,6 \mathrm{~m}$. Slamkalksten dominerer intervallerne $\div 64,0-\div$ $80,7 \mathrm{~m} \mathrm{og} \div 97,6-\div 103,4 \mathrm{~m}$. Kalksand findes ved $\div 58,7-\div 58,8 \mathrm{~m}$ i det $\emptyset$ verste bryozokalkafsnit. En kalkbreccie, der er delvis omdannet til flint, findes ved $\div 67,5 \mathrm{~m}$.

Mergellag findes ved kote $\div 56,0 \mathrm{~m}$ i slamkalkrig bryozokalk, $\mathrm{i} \div 79,8 \mathrm{~m} \mathrm{i}$ bryozopræget slamkalk og i kote $\div 102,3 \mathrm{og} \div 102,8 \mathrm{~m}$ i slamkalk. Afsnit med leret kalk eller kalk med lerslirer findes i kote $\div 55,0-\div 56,0 \mathrm{~m}, \div 63,3-\div$ $76,0 \mathrm{~m} \mathrm{og} \div 98,6-\div 99,4 \mathrm{~m}$. Der er således 3 større afsnit i bryozokalkenheden i TUBA 13, som ikke indeholder ler i synlig mængde, nemlig $\div 50,3-\div$ $55,0 \mathrm{~m}, \div 56,0-\div 63,3 \mathrm{~m} \mathrm{og} \div 79,8-\div 98,6 \mathrm{~m}$. De lerfrie afsnit ligger i dele af lagserien, der er udviklet som bryozokalk, medens de to store afsnit med lerholdige kalksten er praktisk taget sammenfaldende med de dele af lagserien, der er udformet som slamkalksten.

Mergellagene og de lerede kalkpartier er ikke studeret i detaljer, men det kan umiddelbart konstateres, at der er tale om mindst 3 adskilte grupper af lerede dannelser: $a$ ) lagdelte, mørke mergellag (fig. 6 a), b) millimeter tynde lerede lag med opløste bryozoer i svagt lagdelt bryozokalk (fig. 6 b) og c) slump beds (fig. 6 c). 
TUBA 13 Forkortet boreprofil

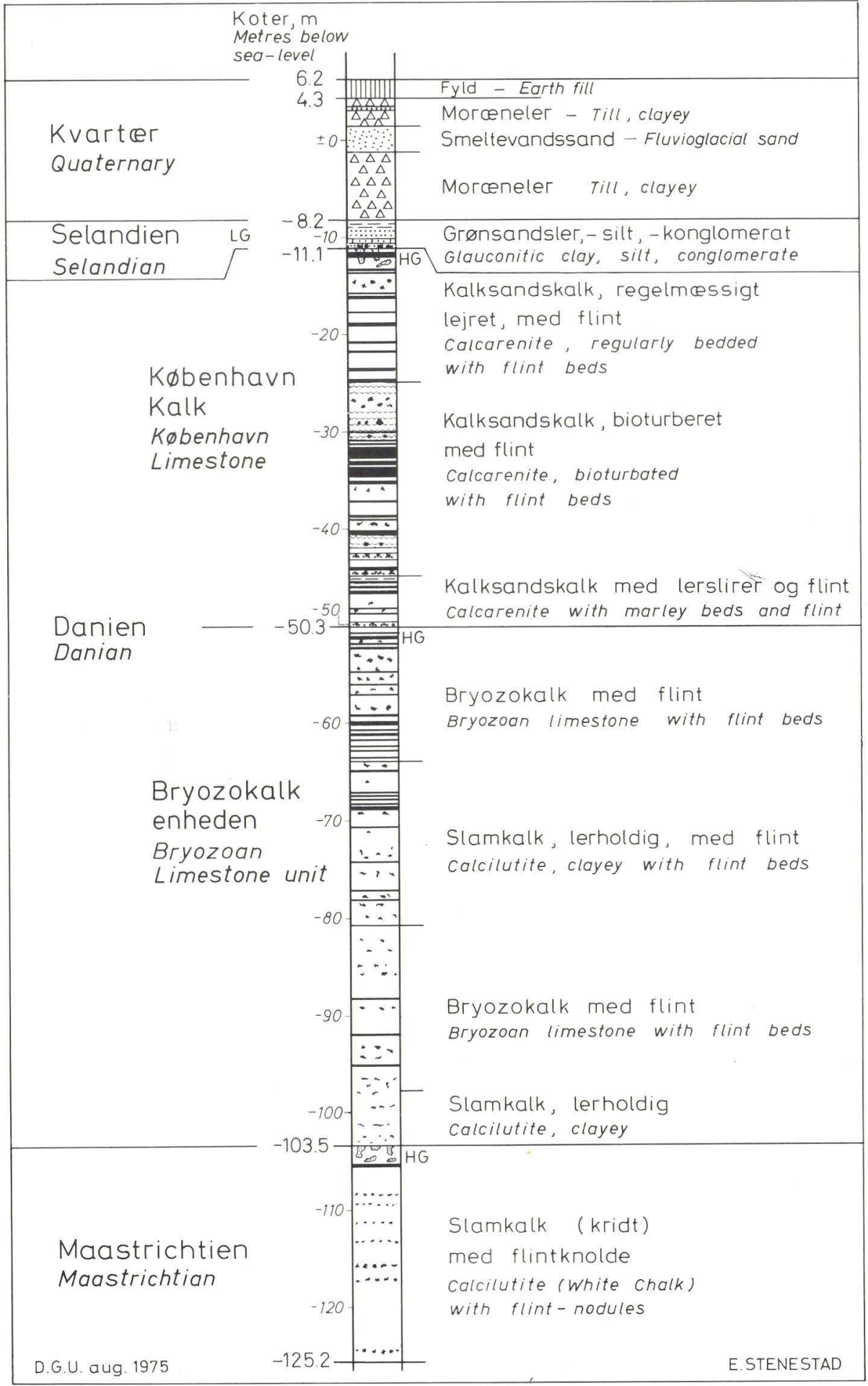




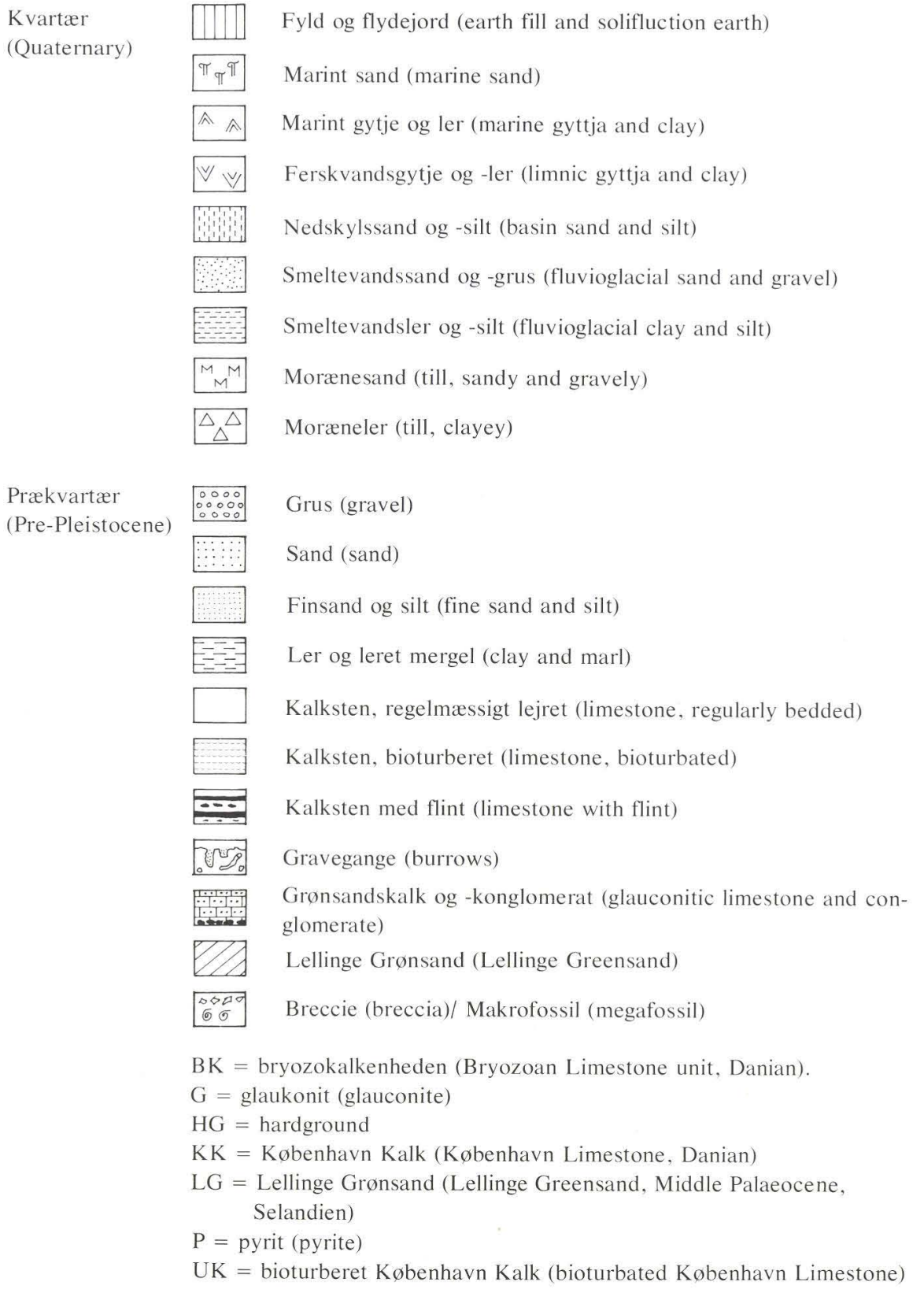

Fig. 5: Forkortet boreprofil for citybaneboringen TUBA 13, DGU nr. 201.3080. Den fuldstændige profilbeskrivelse findes i tabel 2.

Fig. 5: Lithology and stratigraphy of the borehole TUBA 13 (Geological Survey file No. 201.3080). 


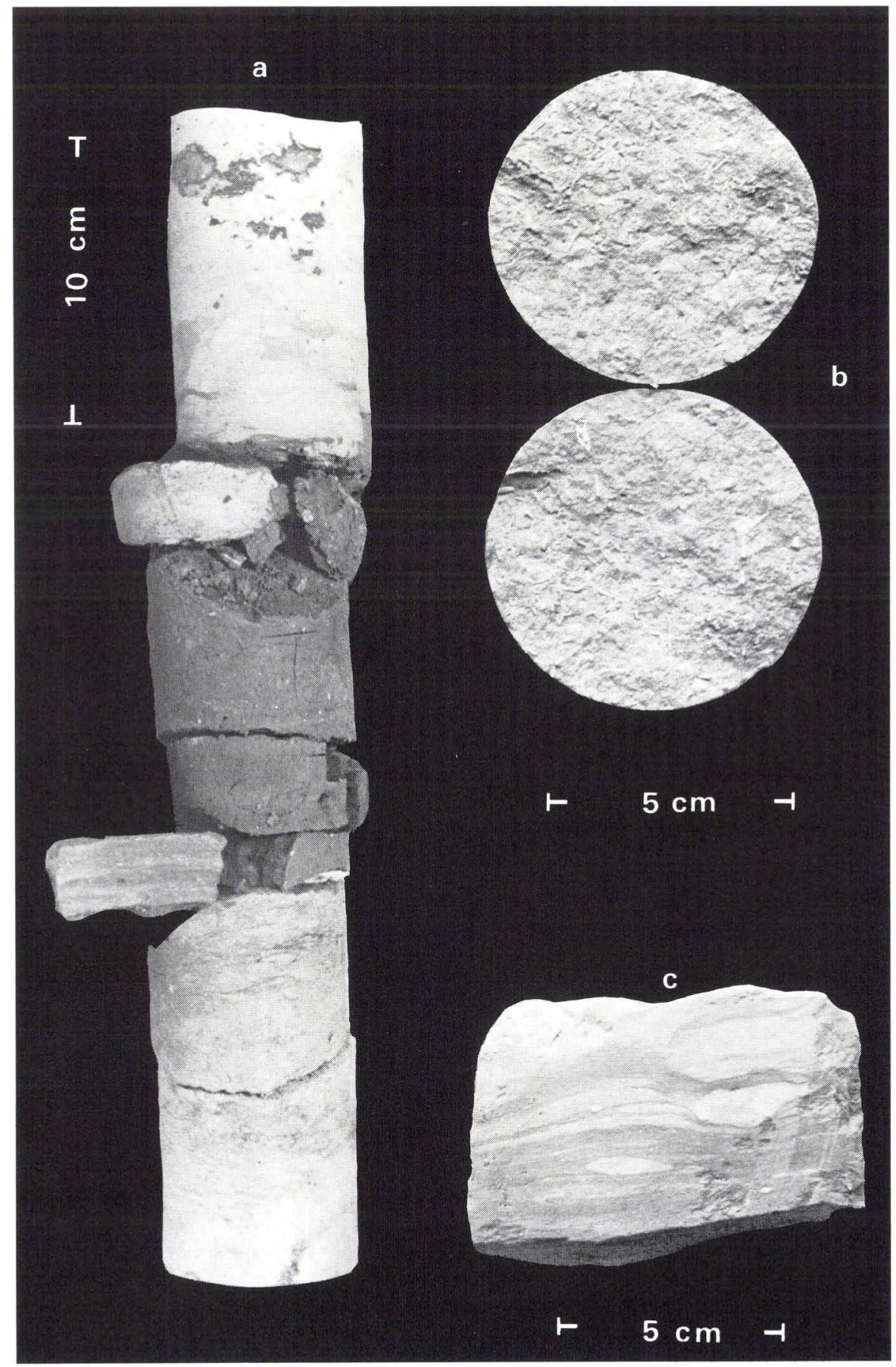


Glaukonit findes i de $\varnothing$ verste $40 \mathrm{~cm}$ af bryozokalkenheden samt i den nederste del af denne ved kote $\div 94, \div 96$ og $\div 103 \mathrm{~m}$.

Flint forekommer i hele bryozokalkenheden i TUBA 13. Den findes i alle grader af forkisling fra forkislet kalk over lys grå, kalkholdig flint til tæt, sort, kalkfri flint (se: Gry \& Søndergaard 1958). Ofte ser man flintknolde med mørk kerne omgivet af lys kappe (fig. 7 a). Den modsatte zonering forekommer dog også, således at mørk flint omgiver lys flint (fig. 7 b). Fotoeksemplerne er hentet fra forskellige bryozokalkboringer i området, men det er de samme flinttyper, som optræder overalt. Flinten findes dels som større eller mindre knolde, som de viste, dels som små, uregelmæssige forkislinger og som forkislet kalk. Fig. 8 a viser stærkt hærdnet og forkislet bryozokalk med uregelmæssige flintpartier. I den stærkt hærdnede og forkislede kalksten kan der findes partier af uhærdnet eller svagt hærdnet kalk (fig. 8 b). Sådanne partier indeholder ofte velbevarede mikrofaunaer.

De 22 citybaneboringer, som nåede nogle meter ned i bryozokalkenheden, dækker hele undersøgelsesområdet, men strækningen fra Gl. Strand til Grønningen er bedst belyst. Fig. 9 viser en skematisk sammenstilling af disse boringers bryozokalkafsnit, med angivelse af leret kalk, lagdelt kalk, hardgrounds, gravegange og glaukonit. Som det vil ses af figuren, er det vanskeligt at påvise nogen lovmæssighed i fordelingen af de lithologiske træk. Dette hænger måske sammen med, at bryozoerne har dannet biohermer eller bio-

Fig. 6: Mergellag og lerslirer i bryzokalkenheden.

6 a: Boring TUBA 64 , prøve 74 , kote $\div 52,7 \mathrm{~m}$;

6 b: Boring TUBA 123 , prøve 82 , kote $\div 61,6 \mathrm{~m}$;

$6 \mathrm{c}$ : Boring TUBA 37 , prøve 68 , kote $\div 52,4 \mathrm{~m}$.

Forf. foto.

Fig. 6: Marley beds and intercalations in the Bryozoan Limestone unit.

6 a: Finely laminated, dark marl in borehole TUBA 64, $52.7 \mathrm{~m}$ below sea-level.

6 b: Thin, clay-coated partings with dissolved bryozoan remains. Borehole TUBA 123,61.6 m

below sea-level.

6 c: Slump bed. Borehole TUBA 37, 52.4 m below sea-level. Photograph by the author.

Fig. 7: Flint i bryozokalkenheden. 7 a: Mørk, kalkfri, tæt flint (evt. replaceret gang af thalassinoid type) med lys, kalkholdig, porøs kappe. Boring TUBA 37, prøve 69, kote $\div 53$ m; 7 b: Mørk, tæt, kalkfri flint med kerne af tæt kalkholdig flint, der er koncentrisk opbygget. Boring TUBA 42 , prøve 83 , kote $\div 50,35 \mathrm{~m}$. Forf. foto.

Fig. 7: Flints from the Bryozoan Limestone unit. 7 a: Dark, dense, non-calcareous flint (possibly filling a thalassinoid burrow) with a mantle of light, calcareous, porous flint. Borehole TUBA 37 , about $53 \mathrm{~m}$ below sea-level. $7 \mathrm{~b}$ : Dark, dense, non-calcareous flint with a core of slightly calcareous, dense flint, which exhibits successive zones of silicification. Borehole TUBA 42, $50.35 \mathrm{~m}$ below sea-level. Photograph by the author. 


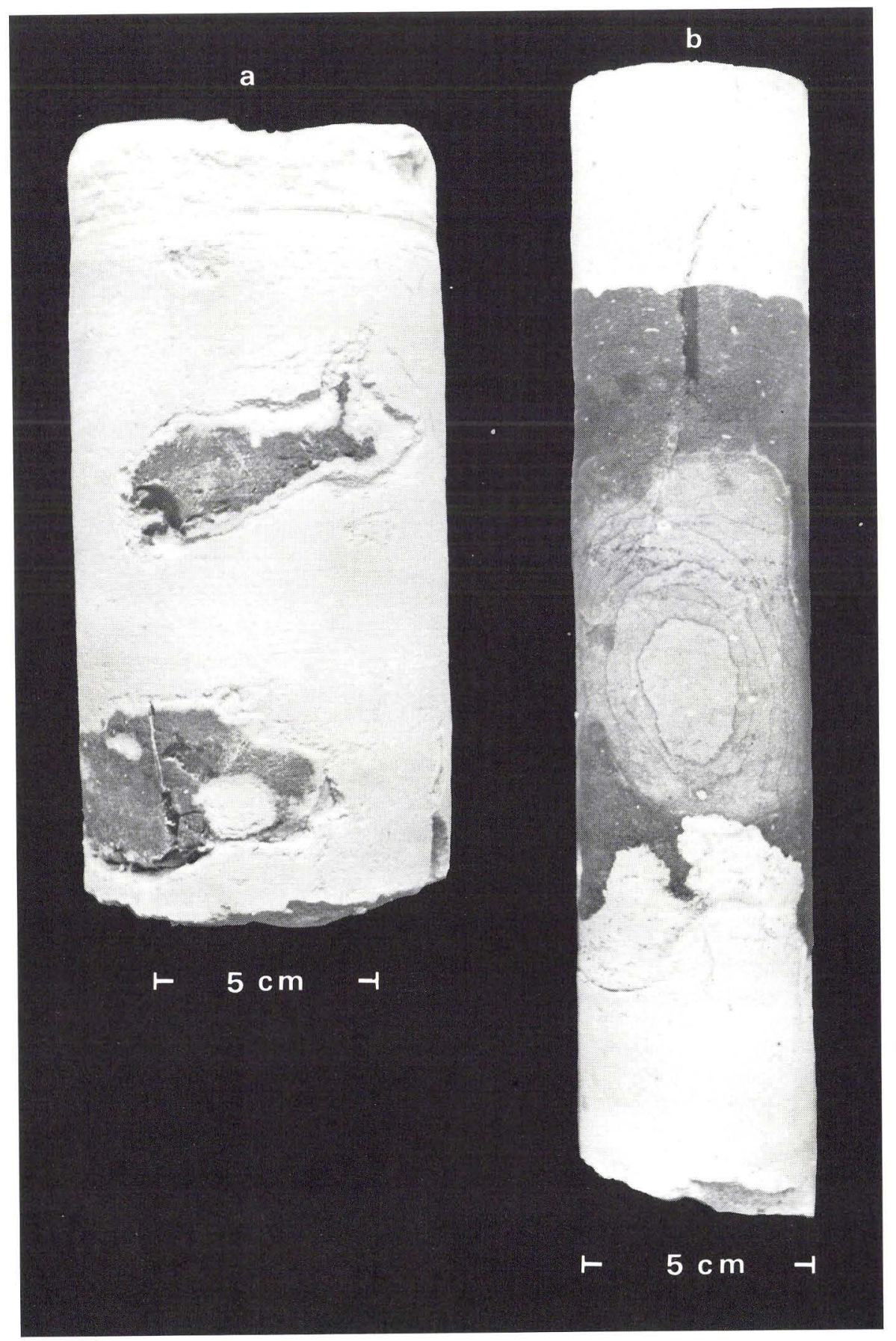




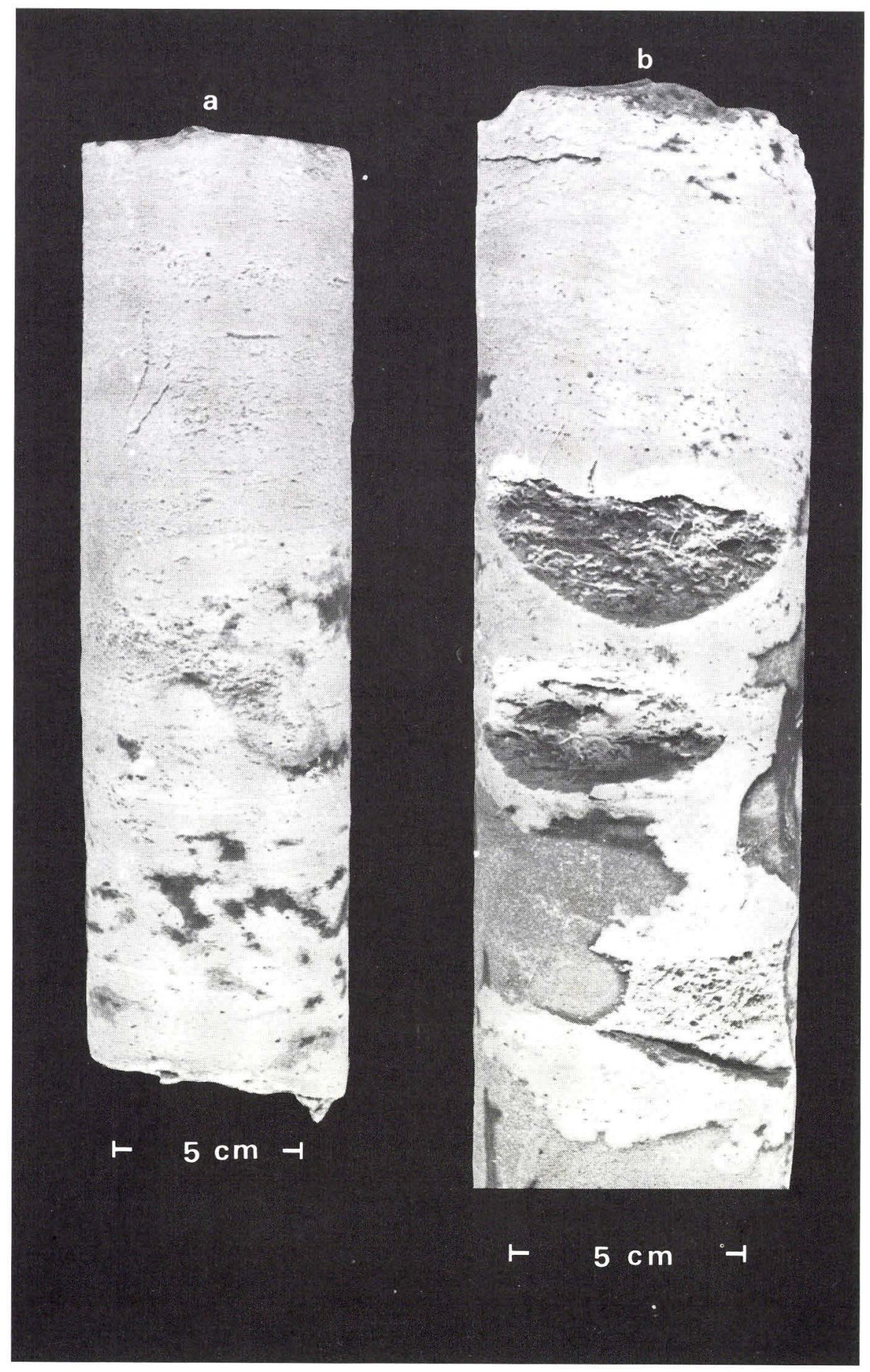


stromer, som er af ringe udstrækning i forhold til afstanden mellem boringerne.

En af de nye Saltholmboringer, boring 12, har givet et komplet snit gennem bryozokalkenheden, idet den underlejres af kridt og overlejres af København Kalk. Forholdene omkring den nedre grænse viste, som tidligere anført, at der her har været tre sedimentationsafbrydelser, af hvilke de to har fundet sted $\mathrm{i}$ den nedre del af danien. Bryozokalkenheden findes mellem kote $\div 4,15$ $\mathrm{mog} \div 66,15 \mathrm{~m}$ (korrigeret dybde), og den er således trods sedimentationsafbrydelserne ca. $9 \mathrm{~m}$ mægtigere end i TUBA 13. Dette skyldes muligvis, at en kraftigere bryozovækst på Saltholm har øget akkumulationshastigheden, idet kalkstenene er langt mere præget af bryozoer i Saltholm boring 12 end i TUBA 13. Det er først under kote $\div 51 \mathrm{~m}$ i Saltholmboring 12, at egentlige slamkalksten er tilstede, og de udgør næppe mere end et par meter af lagserien. Bryozokalken er i Saltholmboring 12 hvidlig og overvejende stærkt hærdnet $\mathrm{og}$ forkislet. De øverste $10 \mathrm{~cm}$, umiddelbart under København Kalken, er dog blød og pastalignende. Uhærdnet kalkslam forekommer lejlighedsvis i danienkalken, f.eks. indesluttet af stærkt hærdnede eller forkislede kalkpartier, lerlag eller flint. De øverste $1,15 \mathrm{~m}$ af bryozokalken er gennemsat af talrige gravegange, der er delvis forkislede. Lerede slirer findes i hele serien, men den samlede lermængde er ikke stor. Glaukonit findes omkring kote $\div 50$ $\mathrm{m}, \div 57 \mathrm{~m} \mathrm{og}$ i de nederste $80 \mathrm{~cm}$ af serien omkring kote $\div 66 \mathrm{~m}$. Gravegange findes i de øverste $125 \mathrm{~cm}$ af serien og optræder desuden spredt i seriens nedre del fra kote $\div 47 \mathrm{~m}$. Der er særligt mange gravegange i de nederste $3-4 \mathrm{~m}$ af bryozokalkenheden. Afsnittet, kote $\div 47-\div 52 \mathrm{~m}$, skiller sig ud fra de $\varnothing$ vrige afsnit ved indslag af glaukonit, slamkalk, mergellag, sammenskyl af makrofossilrester samt enkelte gravegange. Det tyder på, at de facielle betingelser har skiftet hyppigt i det pågældende tidsafsnit. Fremtidige undersøgelser må vise, om det er muligt at korrelere dette med andre begivenheder i bassinet, eller om det er rent lokale forhold, der afspejles.

Fig. 8: Bryozokalk med forkislinger og uhærdnede kalkpartier. 8 a: Stærkt hærdnet og forkislet bryozokalk med uregelmæssige flintpartier. Boring TUBA 121 , prøve 73 , kote $\div 64,5-\div 64,7 \mathrm{~m}$. 8 b: Stærkt hærdnet og forkislet bryozokalk med partier af uhærdnet kalk, som er spulet bort ved borearbejdet, således at bryozostænglerne er frilagt. Boring TUBA 121 , prøve 73 , kote $\div 63,3-\div$ $63,5 \mathrm{~m}$. Forf. foto.

Fig. 8: Bryozoan limestone with silicifications and non-lithified portions. 8 a: Strongly lithified and silicified bryozoan limestone with irregular flint. Borehole TUBA 121, 64.5-64.7 m below sea-level. 8 b: Strongly lithified and silicified bryozoan limestone with non-lithified bryozoan limemud, which has been removed by the drilling process, so that the bryozoan skeletal elements are exposed. Borehole TUBA 121, 63.3-63.5 m below sea-level. Photograph by the author. 


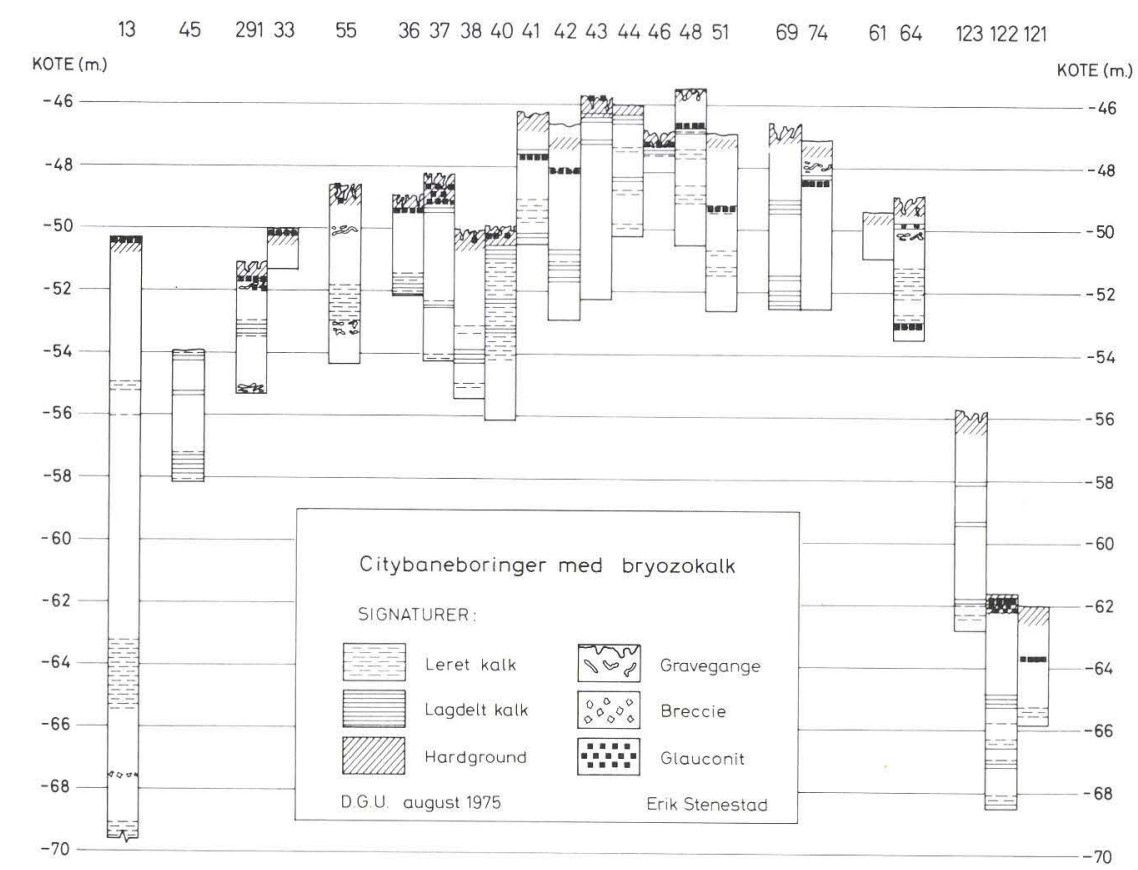

Fig. 9: Skematisk sammenstilling af bryozokalkprofiler fra Hovedbanegården (TUBA 13) til Rădhuspladsen (TUBA 45), Gl. Strand (TUBA 33), Kgs. Nytorv (TUBA 41-44), Grønningen (TUBA 61-64) og Svanemøllen (TUBA 123-121). Flintlag er udeladt, da de er uden direkte relation til aflejringsmiljøet.

Fig. 9: Sections from the Bryozoan Limestone unit, from the south (TUBA 13) to the north (TUBA 121) through Copenhagen City.

Sammenfattende kan man om den københavnske bryozokalkenhed sige, at den præges stærkt af slamkalk og slamkalkrige bryozokalksten. Der forekommer stedvis underordnede indslag af kalksand og af omlejret, lagdelt bryozokalk. I den nederste del af serien, der er præget af slamkalksten, forekommer hyppigt lerede lag. Lerede indslag synes især at være knyttet til de dele af lagserien, der er udformet som slamkalksten. Flint er generelt et underordnet element i bryozokalkenheden.

Gransen mellem bryozokalkenheden og København Kalken

Grænsen mellem disse formationelle enheder er omtalt af blandt andre Rosenkrantz $(1925,1931,1937)$, bl.a. fra kalkstensbruddene på den nordlige del af Saltholm, som er den eneste lokalitet i Københavns nærhed, hvor der er 


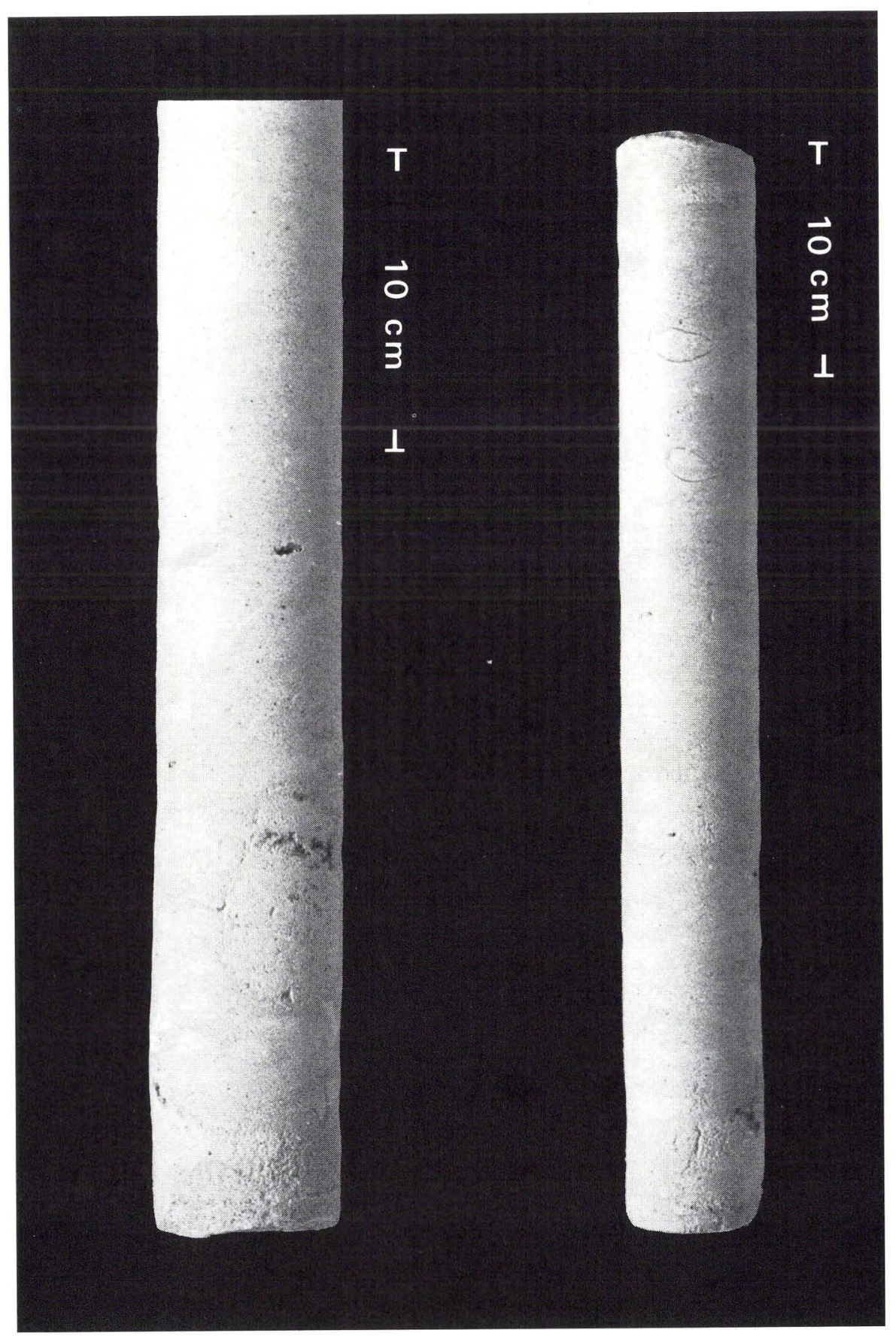


mulighed for at iagttage grænsen direkte. Gravene er dog normalt vandfyldte og utilgængelige. Rosenkrantz angiver som et generelt træk ved lagserien, at der findes et konglomerat i bunden af København Kalken.

Citybaneboringerne øger observationernes antal betydeligt, idet grænsen er fundet $\mathrm{i}$ alle de omtalte 23 bryozokalkboringer. Den er generelt udformet med en mere eller mindre veludviklet hardground. En sådan findes i boringerne TUBA nr. 13, 291, 33, 55, 36, 37, 38, 40, 41, 43, 44, 46, 48, 51, 69, 74, 61, 64, og i alle tre Svanemølleboringer, 123, 122 og 121 (rækkefølge som på fig. 9). I sin typiske udformning består hærdningshorisonten af stærkt hærdnet, let glaukonitholdig bryozokalk med gravegange, som er udfyldt af glaukonitholdigt, skalrigt, let leret kalkmateriale eller af kalksandskalk (fig. 10). Gravegangsfyldet er oftest blødere end den omgivende kalksten, men stærkt hærdnede eller forkislede gravegangsudfyldninger forekommer også. I to af boringerne, TUBA 42 og 45, er grænsen markeret af et flintlag.

I boring 12 på Saltholm er de øverste $125 \mathrm{~cm}$ af bryozokalken overvejende stærkt hærdnet og delvis forkislet. Den indeholder flintknolde og delvis forkislede gravegange. Den overlejres af kalksandskalk med flintpartier.

Det fremgår af det anførte, at grænsen mellem bryozokalkenheden og København Kalken i Københavnsområdet er karakteriseret ved en sedimentationsafbrydelse, som i de fleste tilfælde er markeret af en hardground. I enkelte tilfælde vil man finde et konglomerat eller et flintlag ved grænsen. Almindeligvis vil der være indslag af glaukonit i grænseområdet.

\section{København Kalk \\ (Definition p. 57).}

I de tidligere afsnit har citybaneboring TUBA 13 făet en særlig omtale, fordi den er væsentlig dybere end andre boringer i området. København Kalken ligger imidlertid så højt, at henved 500 boringer er nået ned i kalksten, som

Fig. 10: Grænsen mellem bryozokalkenheden og København Kalken i en boring ved Svanemøllen.

I den stærkt hærdnede bryozokalk findes gravegange, der er udfyldt af glaukonitholdigt, skalrigt kalkmateriale fra København Kalken, som hviler på den eroderede bryozokalkoverflade. Boring TUBA 123, prøve 76, kote $\div 55,7-\div 56,2 \mathrm{~m}$. Forf. foto.

Fig. 10: The boundary between the Bryozoan Limestone unit and the København Limestone. Strongly lithified bryozoan limestone with burrows, which are infilled with glauconitic calcarenitelcalcisiltite, rich in shell debris originating from the Kobenhavn Limestone, which overlies the eroded bryozoan limestone. Borehole TUBA 123, 55.7-56.2 m below sea-level. Photograph by the author. 
tilhører denne formation. Ca. 175 af disse boringer er citybaneboringer. For alle 500 boringer foreligger tegnede profiler og beskrivelser. På de følgende sider vises et udvalg af boringer. De er opstillet i omtrent rigtig geografisk rækkefølge, men ikke med rigtig indbyrdes afstand. Diagrammerne, fig. 11-20, viser således ikke strukturforholdene. Ønsker man et indtryk af disse, er det bedre at benytte strukturkortene (fig. 41-45) eller de på grundlag af disse kort fremstillede vertikalsnit (fig. 46-47). Hensigten med diagrammerne er alene, - i stærkt skematisk form - at fremlægge lithologiske og biostratigrafiske observationer. Det fremgår af diagrammerne, at København Kalken generelt er udformet med en nedre lerpræget lagserie, en mellemste bioturberet lagserie, og en øvre mere regelmæssigt lejret lagserie (se tillige fig. 5).

København Kalken består i dominerende grad af kalksandskalk (fig. 21), der er en finkornet sand- og finsandsaflejring, som består af kalkkorn. Ifølge Larsen (1961) kan indholdet af kalkpartikler tilhørende sandfraktionen stedvis være så lavt som ca. $30 \%$, medens kalkslam udgør resten. Nielsen (1976) angiver som gennemsnit af 7 analyser fra TUBA 13, at kun 20,7 $\pm 6,0 \%$ af partiklerne er større end 63 my. De pågældende kalksten kan således lithologisk betegnes sandet slamkalk eller kalkslamrig calcarenit. Nielsen (1976) karakteriserer i petrografisk henseende København Kalkens bjergarter som biomicrit. Dog er de øverste ca. $8 \mathrm{~m}$ i TUBA 13 udviklet som biosparit. I denne publikation bibeholdes af de tidligere nævnte ărsager den lithologiske betegnelse kalksandskalk. I kalken findes skaller og skalfragmenter af for-

Signaturer til figs. 11-20. (Legend to figs. 11-20).

Omlejringszone (reworked material)

A Subbotina triloculinoides zone

$\square$ Overgangslag (transition zone)

$\square \quad$ Globoconusa daubjergensis zone (lower zone)

D. Globigerina danica zone

-. G. danica zone med (with) G. daubjergensis gigantea

$凶$

Turborotalia sp. 4 subzone

Sort udfyldte symboler angiver prover med omlejrede foraminiferer fra kridt. (Black infilled symbols indicute samples with reworked forans from the White Chalk).

Øvrige signaturer som pa fig. 5. (Other symbols and signatures as in fig. 5). 


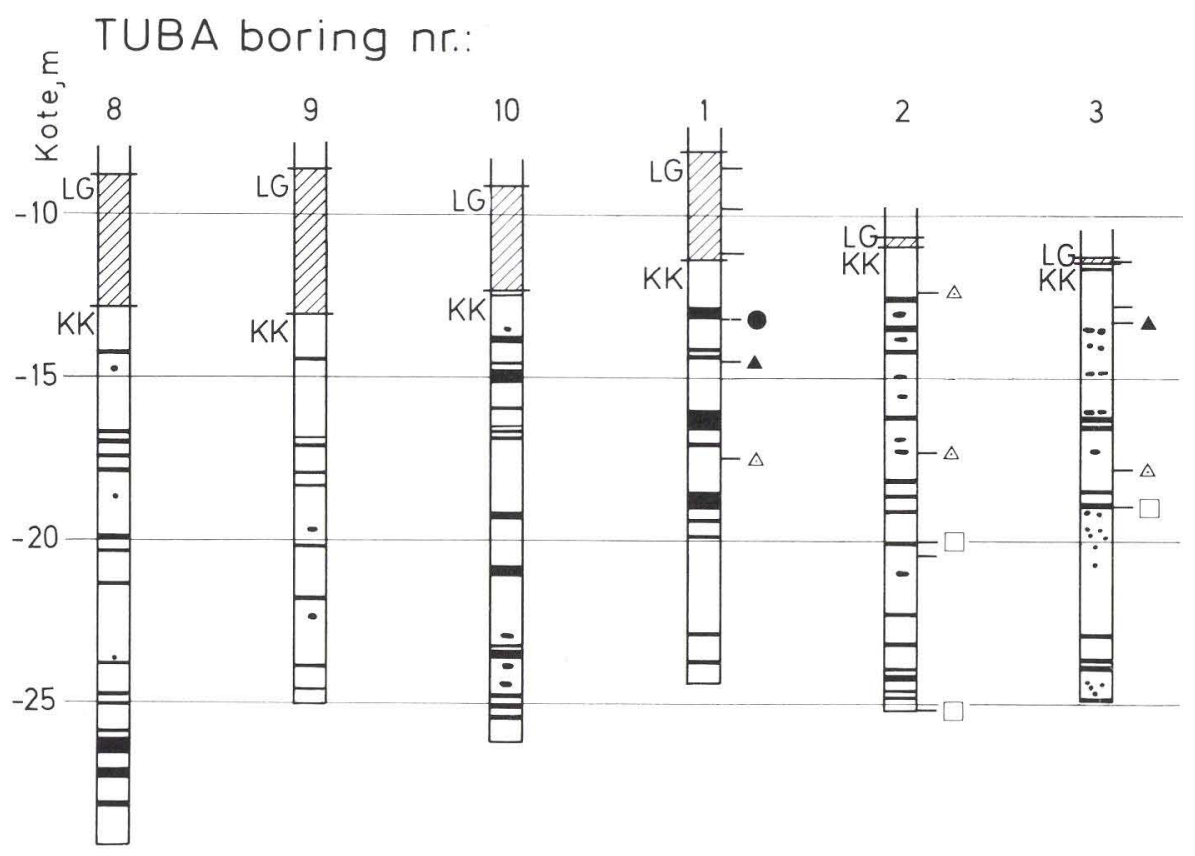

TUBA boring nr:

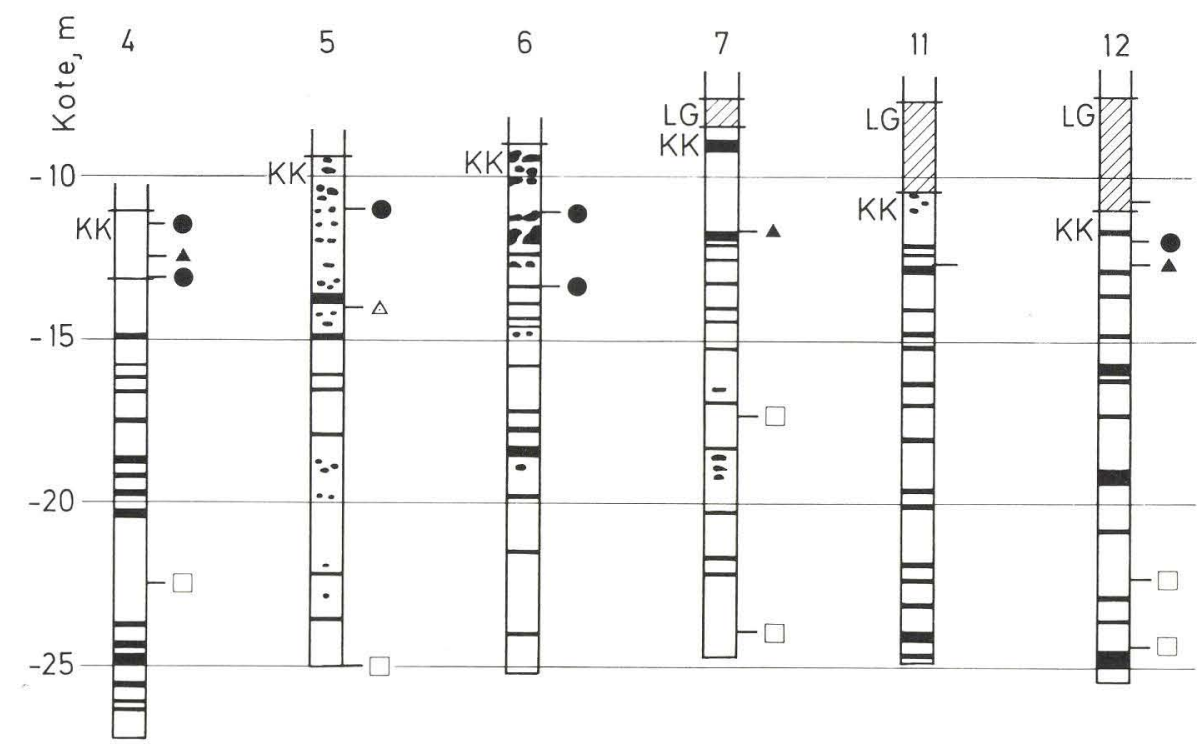

Fig. 11: Boringer på strækningen Ingerslevsgade-Hovedbanegården.

Fig. 11: Boreholes TUBA 8-12 near the Central Station. 

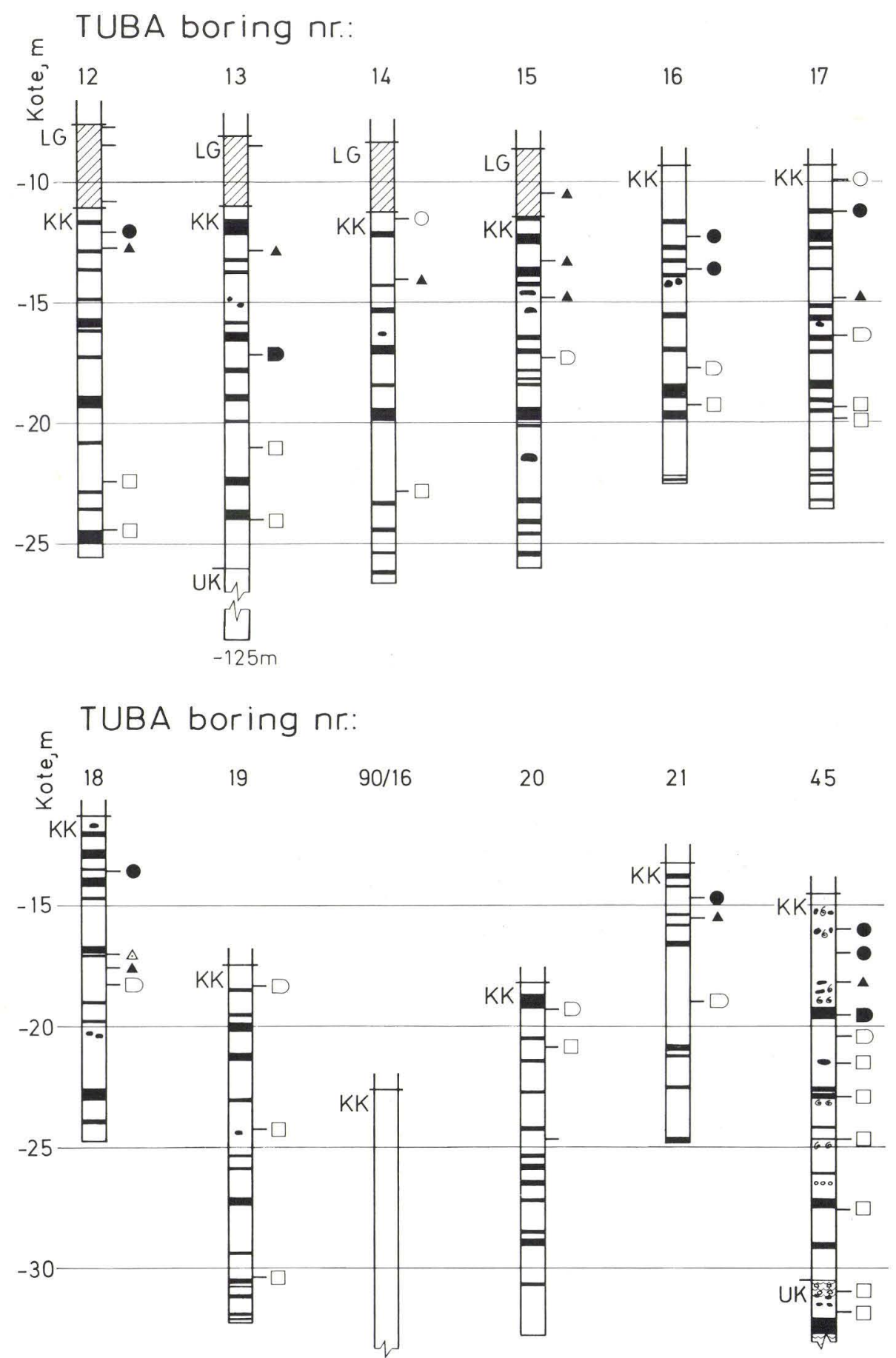

Fig. 12: Boringer på strækningen Hovedbanegården-Rådhuspladsen.

Fig. 12: Boreholes TUBA 12-45 between the Central Station and the Town Hall. 


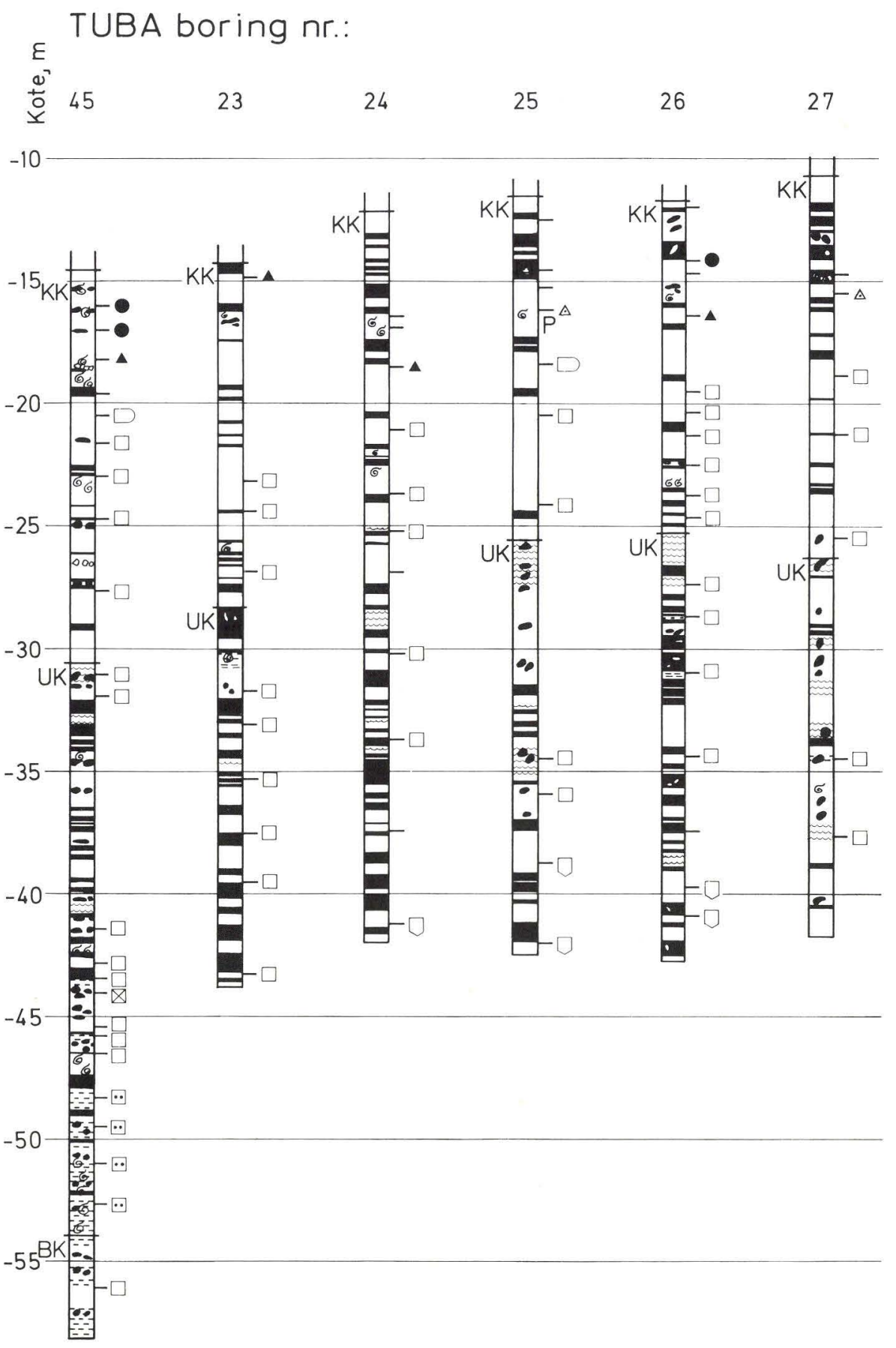

Fig. 13: Boringer på strækningen Rådhuspladsen-Frederiksholms Kanal.

Fig. 13: Boreholes TUBA 45-27 between the Town Hall and Frederiksholms Kanal. 
TUBA boring nr::

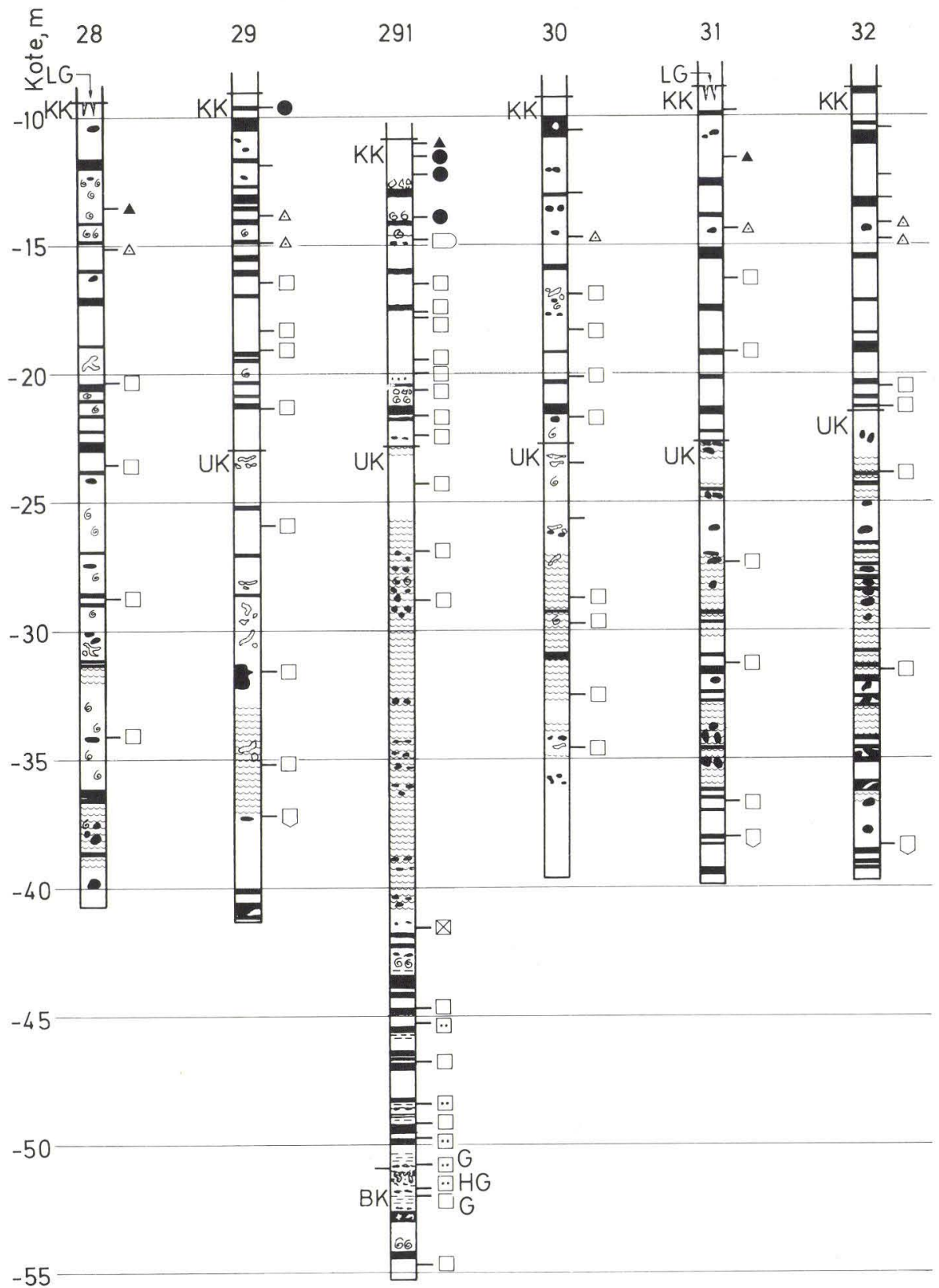

Fig. 14: Boringer pả strækningen Frederiksholms Kanal - Gl. Strand.

Fig. 14: Boreholes TUBA 28-32 along Frederiksholms Kanal and Gl. Strand. 
TUBA boring nr:

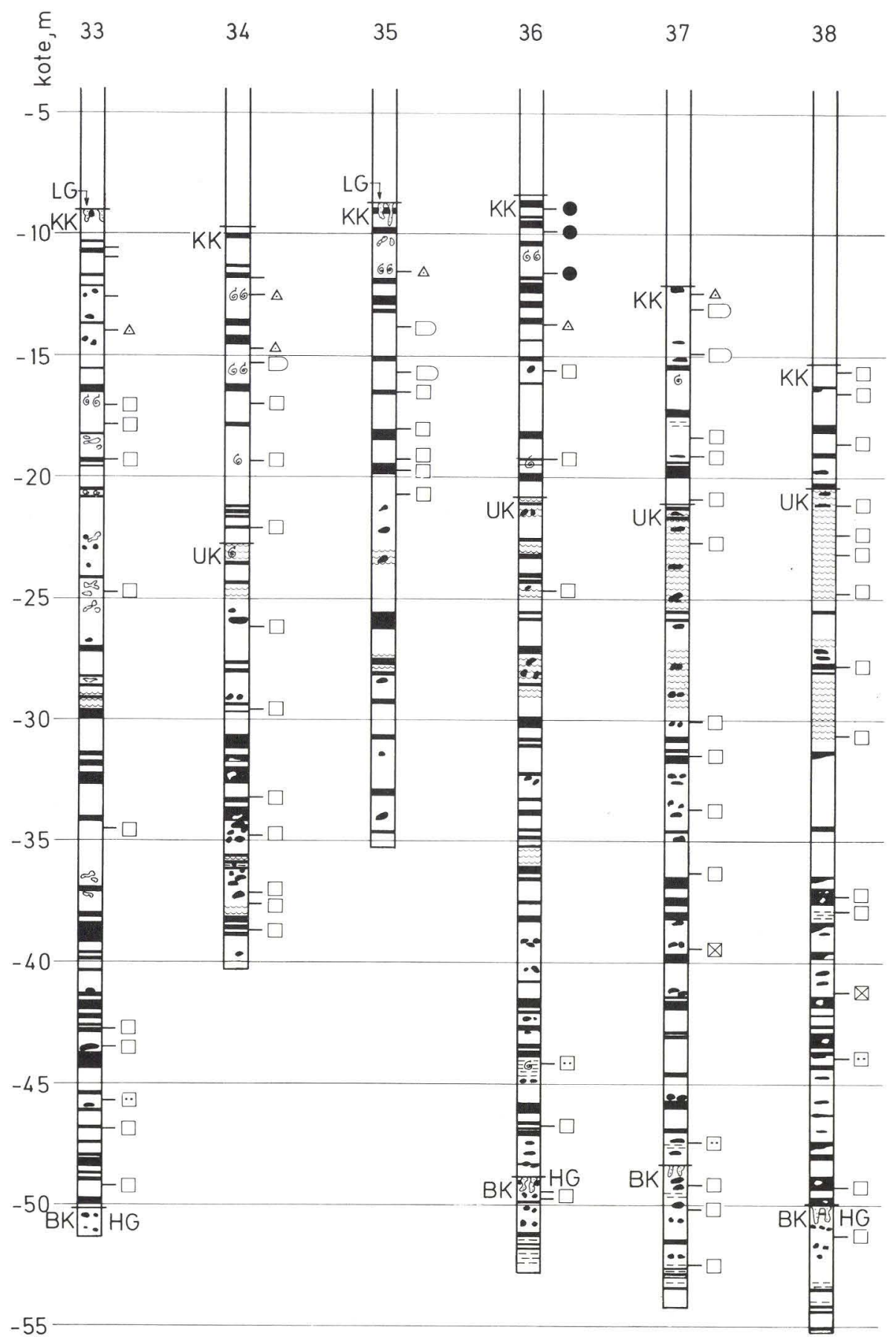

Fig. 15: Boringer pà strækningen Gl. Strand-Nikolaj Plads.

Fig. 15: Boreholes TUBA 33-38 from Gammel Strand to Nikolaj Plads. 
TUBA boring nr.:

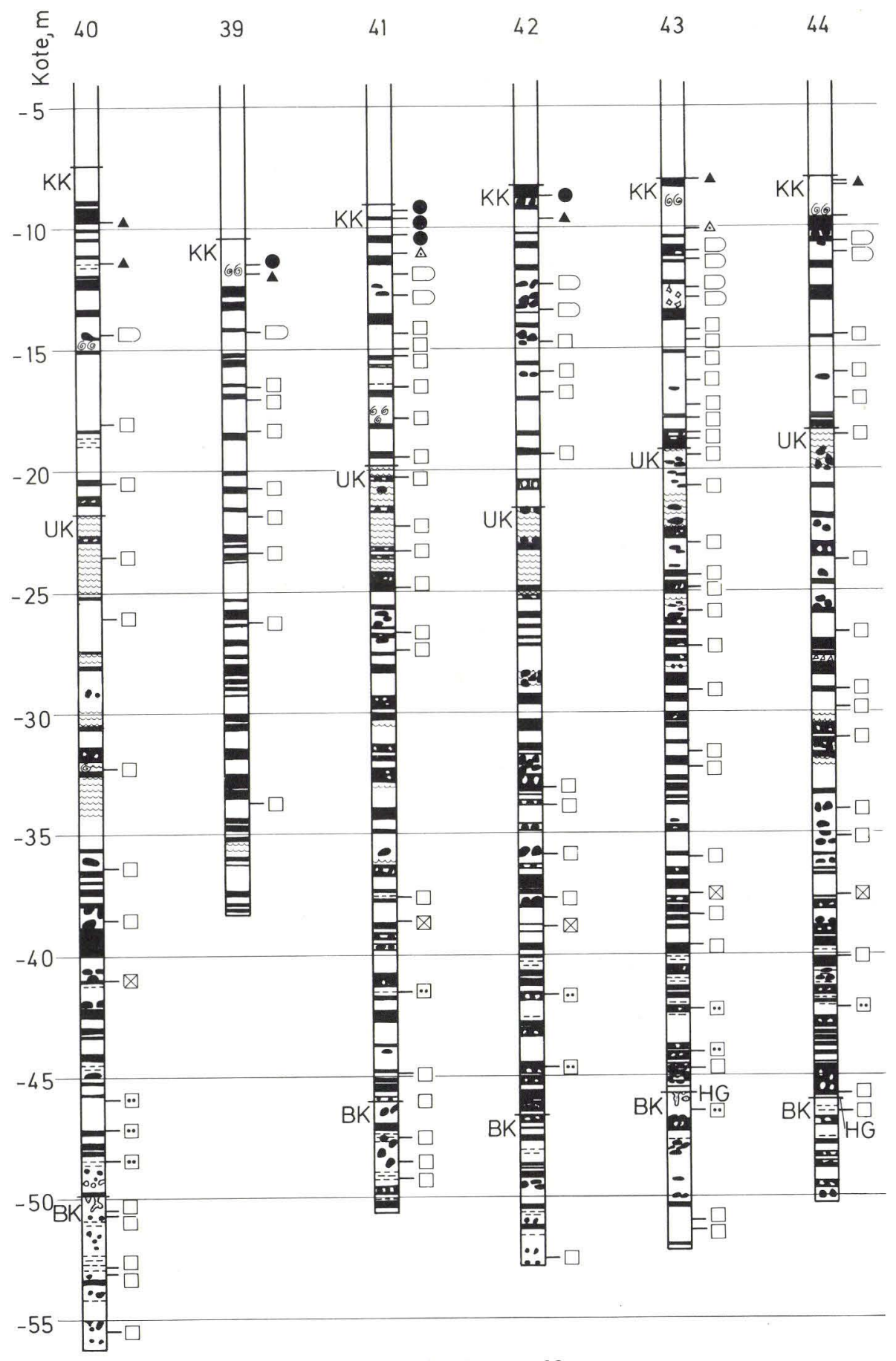

Fig. 16: Boringer på strækningen Bremerholm-Kongens Nytorv.

Fig. 16: Boreholes TUBA 40-44 between Bremerholm and Kongens Nytorv. 
TUBA boring nr.:

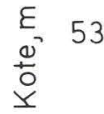
55
554
58
585
60

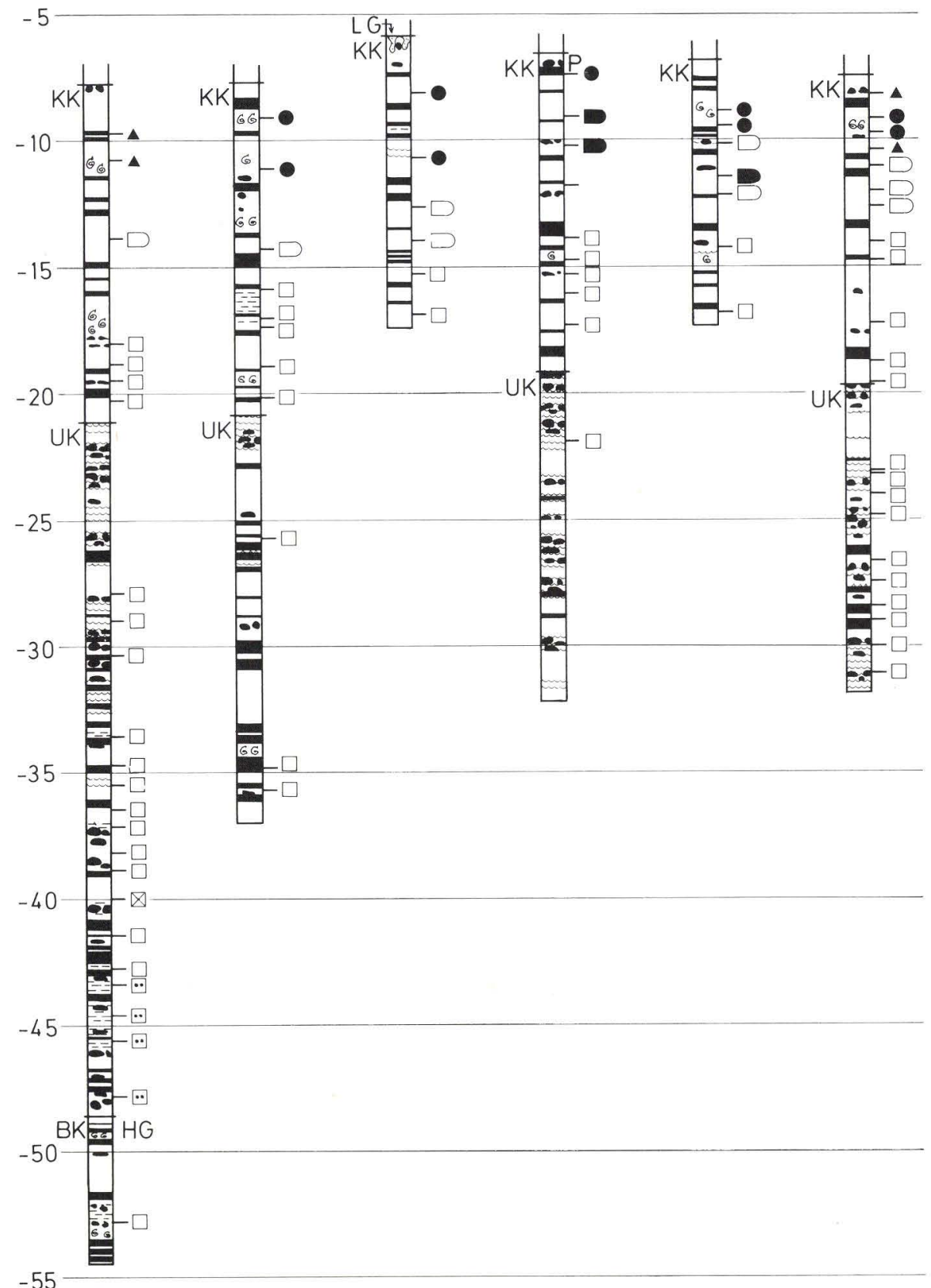

Fig. 17: Boringer på strækningen Slotsholmen-Bredgade. Disse boringer dækker et område lidt sydøst for boringerne $36-46$ (se fig. 1).

Fig. 17: Boreholes TUBA 53-60 southeast of boreholes TUBA 36-46 (see fig. 1). 
TUBA boring nr:

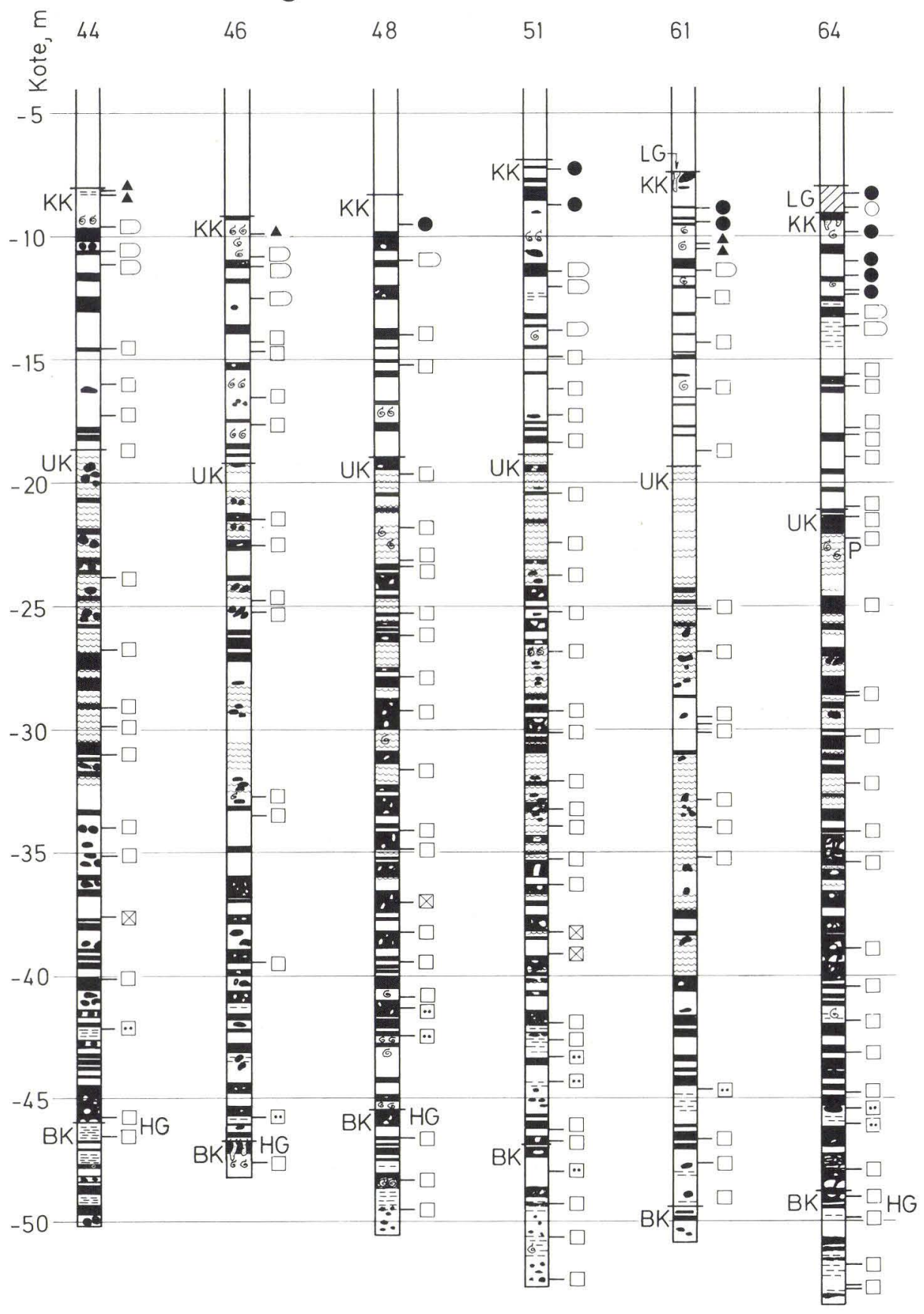

$-55$

Fig. 18: Boringer på strækningen Kongens Nytorv-Grønningen.

Fig. 18: Boreholes TUBA 44-64 between Kongens Nytorv and Gronningen. 
TUBA boring $n r:$ :

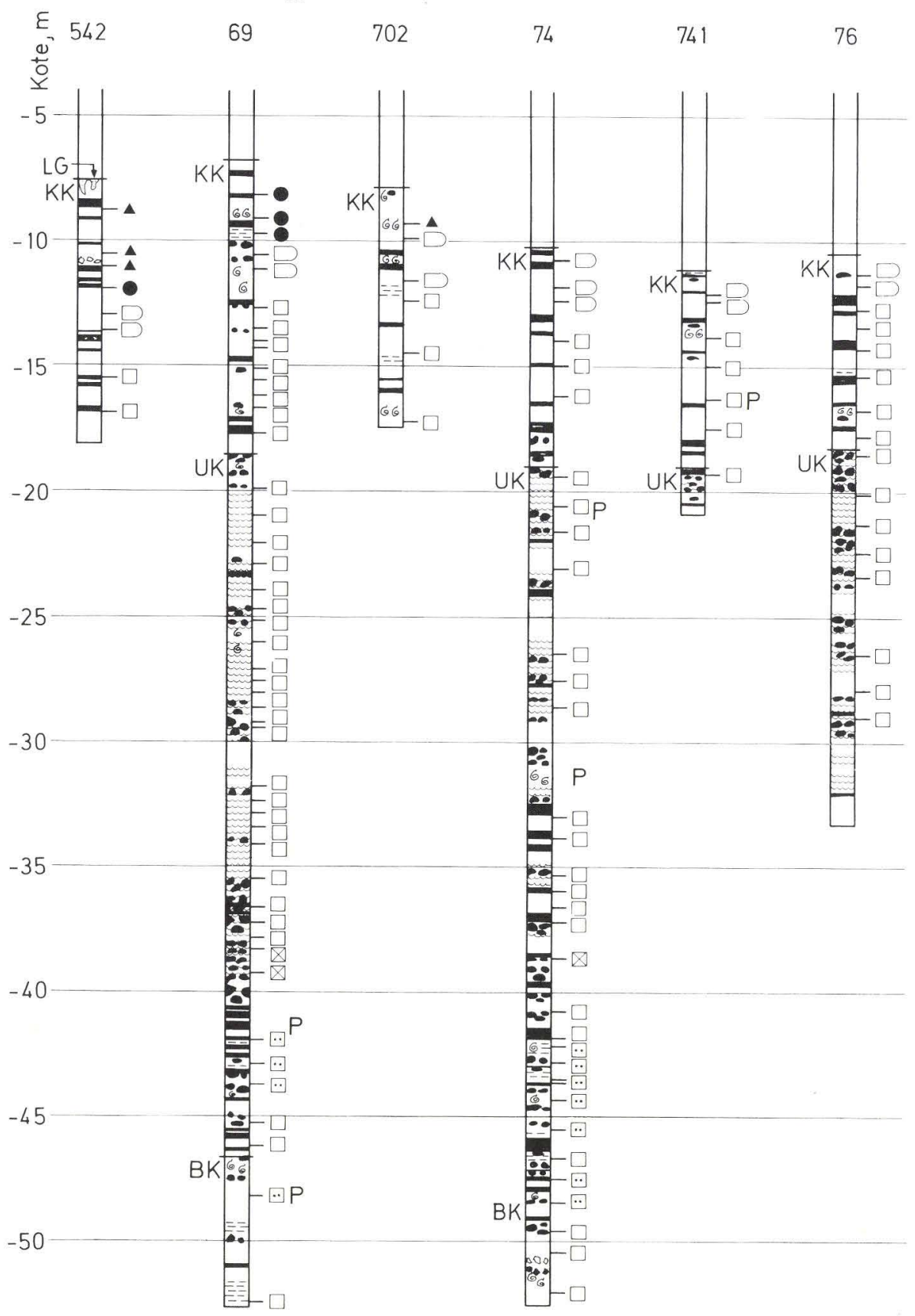

$-55$

Fig. 19: Boringer i kvarteret omkring Frederikskirken.

Fig. 19: Boreholes TUBA 542-76 in the vicinity of Frederikskirken. 
TUBA boring nr:

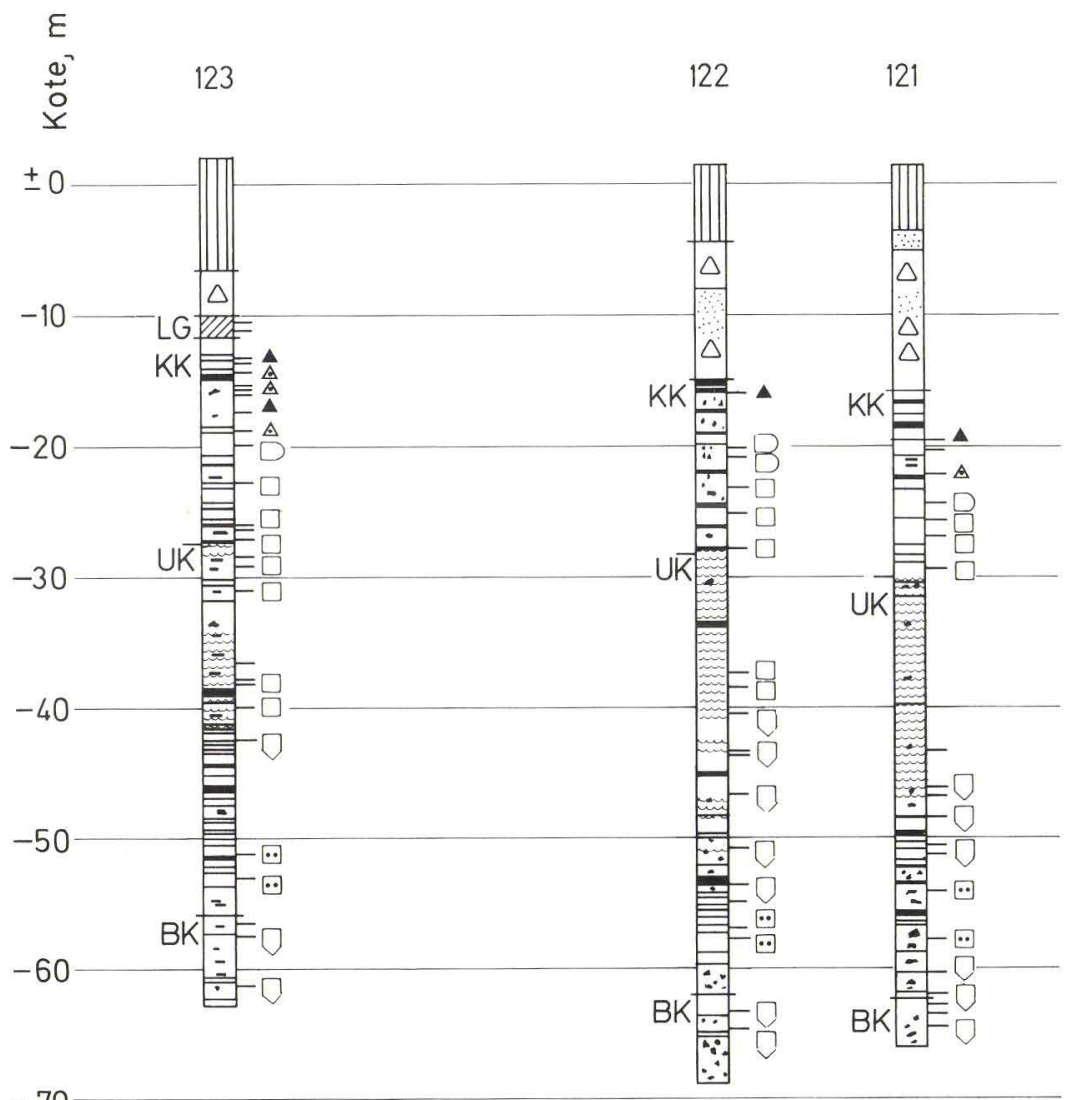

Fig. 20: Boringer ved Svanemøllen.

Fig. 20: Boreholes TUBA 121-123 at Svanemollen.

skellige marine organismer samt små mængder af glaukonit og svovlkis. I citybaneboringerne er der iagttaget nogle nye varianter af de kendte bjergartstyper. I tre boringer ved Gl. Strand (TUBA 32, 33 og 331) er der øverst i København Kalken fundet en flintbreccie, som består af skarpkantede flintbrokker i finkornet kalkmatriks (fig. 22). Som en sjælden variant af kalksandskalk finder man i TUBA 13 en tæt, hvid, stærkt hærdnet kalksten, som iøvrigt kun er observeret i boringer ved Højbro Plads. Den mest udbredte af de nye lithologiske typer er den bioturberede kalksandskalk, som forekommer i store dele af det østlige København. Den består af stærkt vekslende, uregelmæssigt formede partier af svagt varierende kornstørrelse og kalkslamindhold og sædvanligvis med uregelmæssigt vekslende hærdning (fig. 23). I 


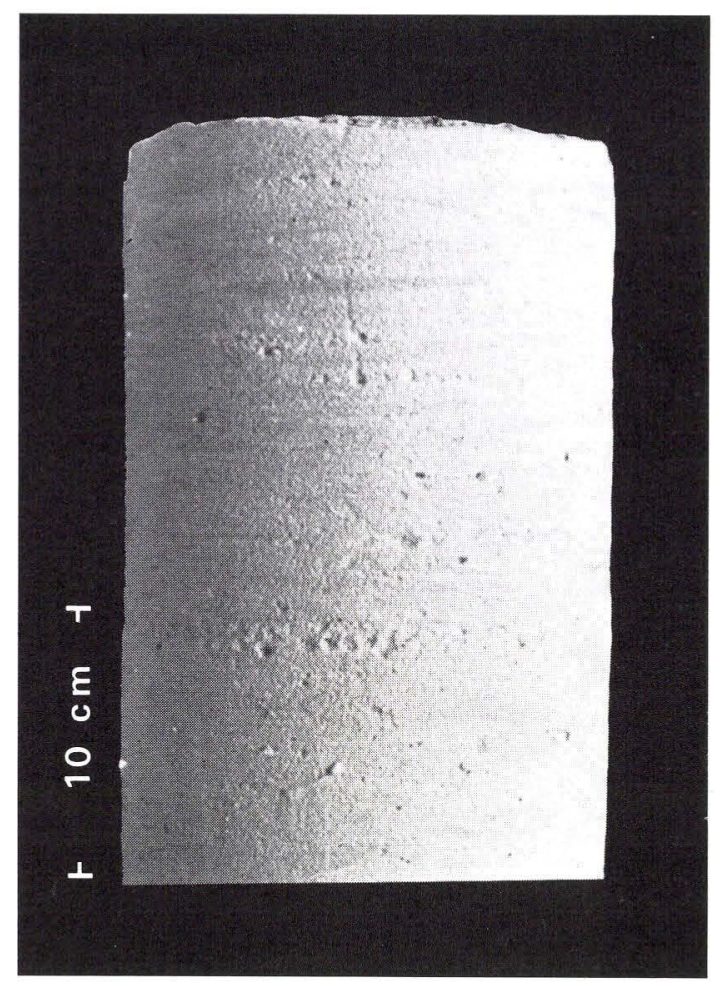

Fig. 21: Kalksandskalk, let hærdnet, med vandrette, lerede slirer. Boring TUBA 123, prøve nr. 49 , kote $\div 34,3-\div 34,5 \mathrm{~m}$. Forf. foto.

Fig. 21: Calcarenitic limestone, slightly lithified, with horizontal, marly streaks from the Kobenhavn Limestone. Borehole TUBA I23, 34.3-34.5 m below sea-level. Photograph by the author.

et kernestykke på 5-10 cm findes ofte materiale af alle hærdningsgrader, fra uhærdnet til stærkt hærdnet og forkislet kalk samt flint. Den bioturberede kalksandskalk findes næsten udelukkende i den mellemste del af København Kalken, som derfor kan betragtes som et informelt member, bioturberet København Kalk. Bioturbation er dog også iagttaget enkelte steder i de øvrige dele af København Kalken (fig. 11-20), og gravegange, samt små lag af breccieret kalk og af sammenskyllet ler-og kalkmateriale findes mange steder i lagserien. Der er også set eksempler på slumping. Foraminiferfaunaerne viser, at det $\mathrm{i}$ almindelighed må være forholdsvis nysedimenteret materiale, som er omlejret, idet de ikke indeholder former, som er tydeligt ældre end resten af faunaen. Dog er det et gennemgående træk, at den øverste del af København Kalken indeholder stærkt maastrichtienprægede planktoniske foraminiferfaunaer (fig. 11-20).

Kalksandskalken kan være uhærdnet, f.eks. inden i flintknolde, eller den 


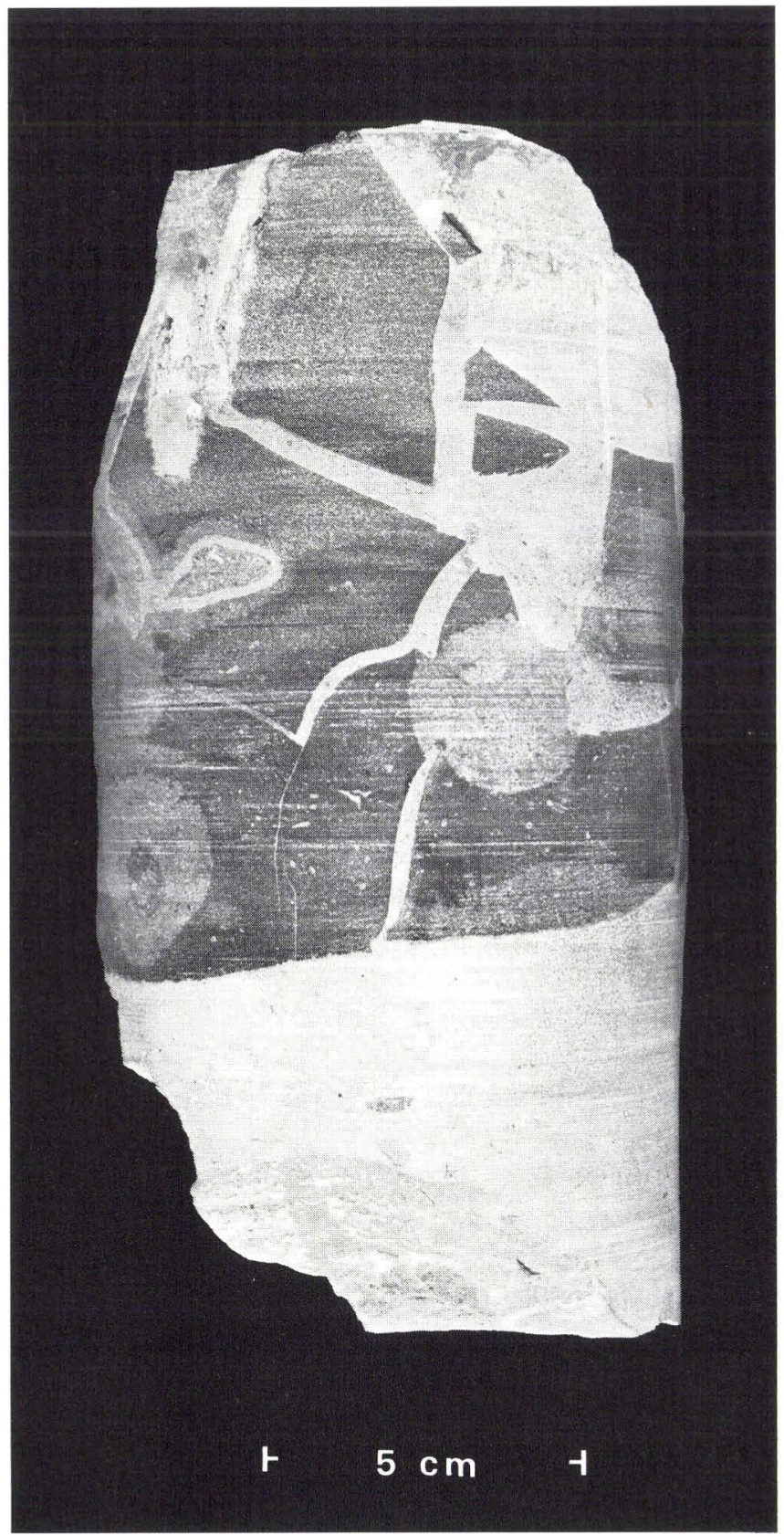

Fig. 22: Flintbreccie fra toppen af København Kalken ved Gl. Strand. Boring TUBA 33, prøve 14 , kote $\div 9,1 \mathrm{~m}$. O. Neergaard Rasmussen foto.

Fig. 22: Flintbreccia from the uppermost part of the Kobenhavn Limestone at Gammel Strand. Borehole TUBA 33, $9.1 \mathrm{~m}$ below sea-level. Photograph by O. Neergaard Rasmussen. 


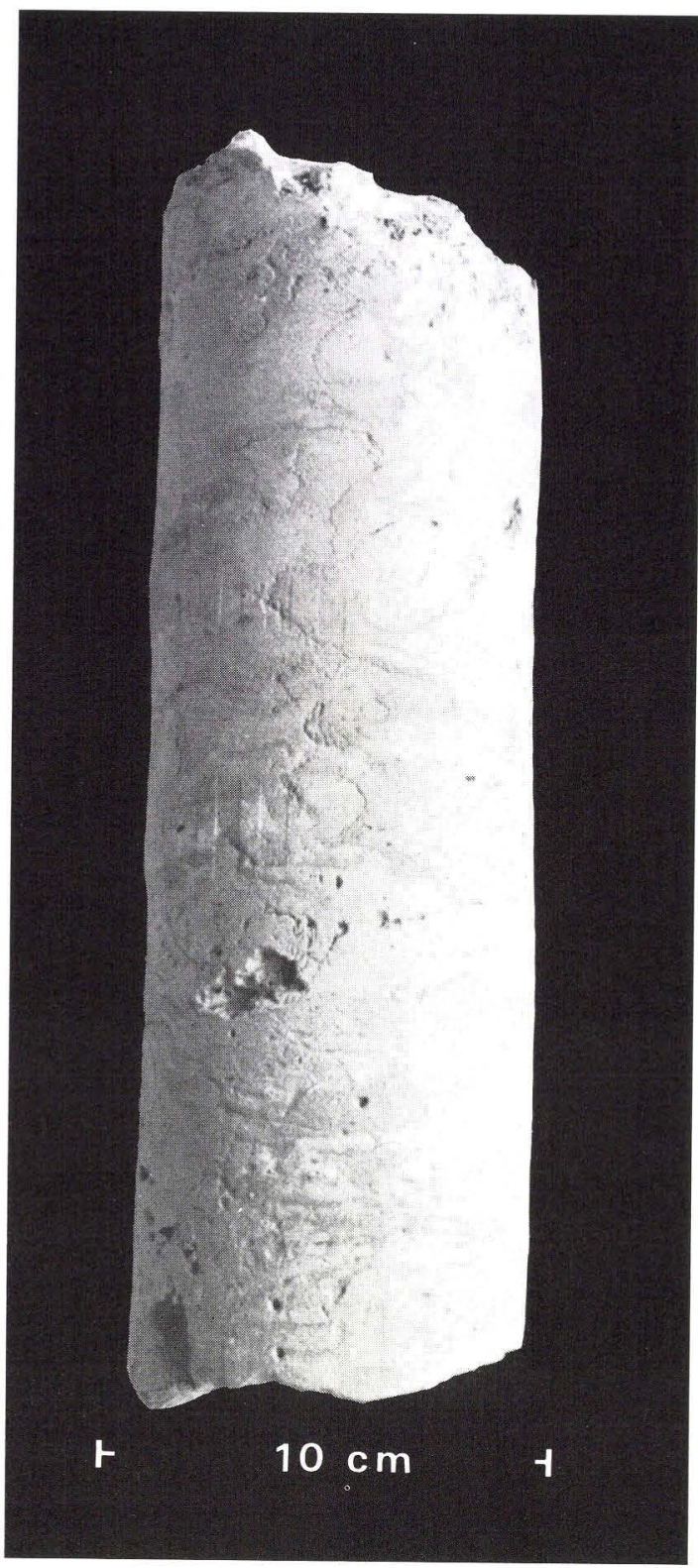

Fig. 23: Bioturberet København Kalk. Kalksandskalk med lerslirer og gravegange af thalassinoid type. Boring TUBA 123 prøve nr. 50, kote $\div 35,5-\div 35,7 \mathrm{~m}$. Forf. foto.

Fig. 23: Bioturbated København Limestone. Calcarenitic limestone with marly intercalations and thalassinoid burrows. Borehole TUBA 123,35.5-35.7 m helow sea-level. Photograph by the author. 


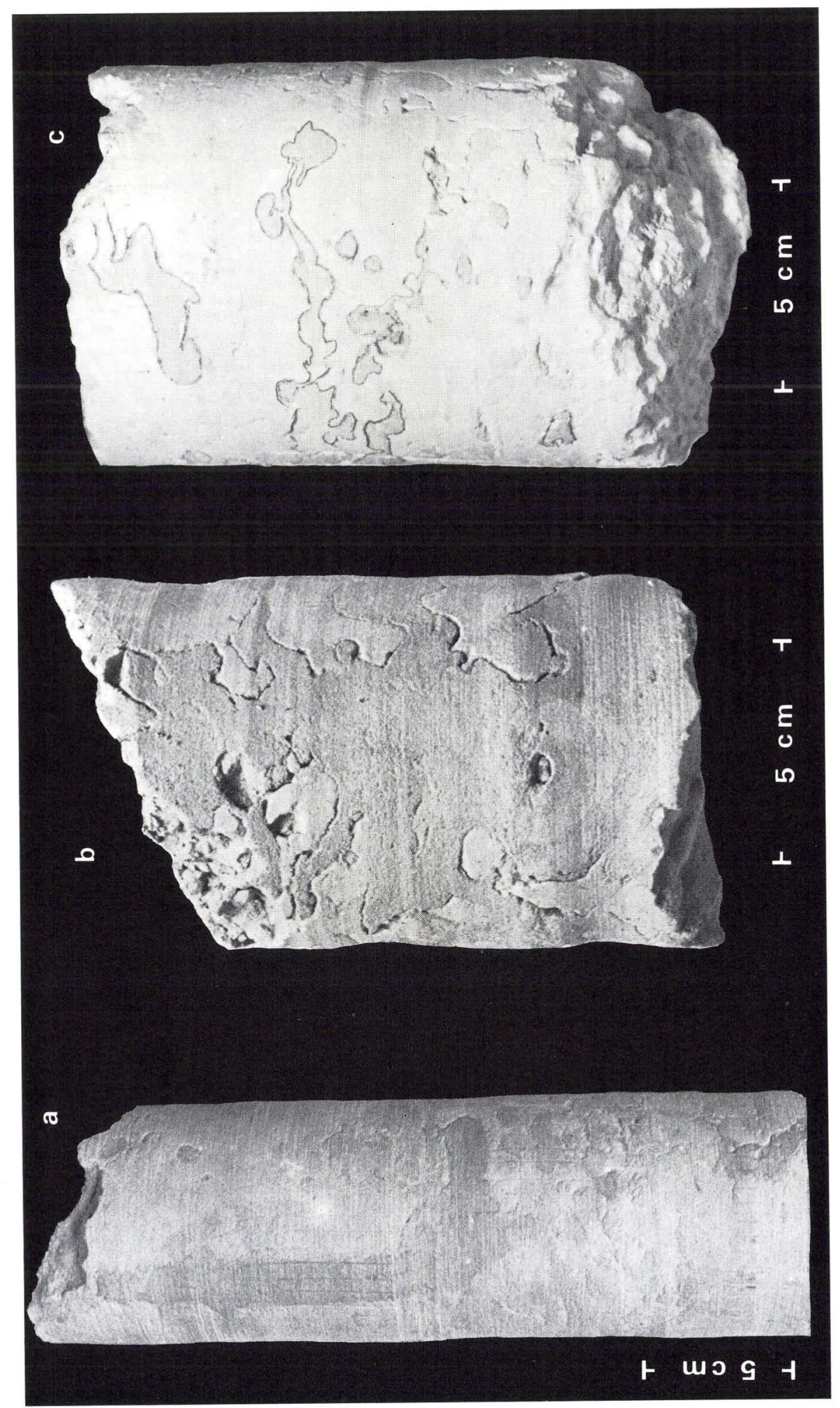


kan være hærdnet til kalksten af vekslende hårdhed. Den grå, stærkt hærdnede, klingende type omtales i ældre litteratur som Saltholmskalk, en teknisk betegnelse, der også har været anvendt for stærkt hærdnet bryozokalk. Hærdningen af København Kalken har, såvidt det kunne bedømmes ved prøvebeskrivelsen, i overvejende grad bestået i en kalcitcementering af den uhærdnede kalk, medens forkisling har spillet en mindre rolle. Den hærdnede kalk optræder især som hårde kalkbænke, der kan følges over lange strækninger (fig. 46, 48, 49, 52, 54, 55). Særlig interesse knytter sig til de regionalt udbredte hærdningshorisonter ved formationsgrænser (hardgrounds), som vidner om geologiske begivenheder i forbindelse med formationsskiftet. København Kalken har фverst en hardground eller et flintlag, som tilsammen danner den hårde flade, hvortil istidens gletschere og smeltevandsstrømme i visse områder eroderede.

Flint udgør en væsentlig del af København Kalken. Den danner sammenhængende, massive, decimetertykke lag, som i store profiler kan følges over lange strækninger (fig. 48, 54). Flint optræder desuden som uregelmæssige forkislinger i kalklagene og som kegleformede dannelser, »flinttragte (fig. 55), som muligvis er af organisk oprindelse, eventuelt repræsenterende ichnogenus Paramoudra (Bromley et al. 1975 fig. 6 F, pl. 1 A). Forkislingen kan være diffus eller med skarpe grænser. Forkisling og flintdannelse kan undertiden tydeliggøre sedimentstrukturer, f.eks. uregelmæssig lejring / bioturbation (fig. 25, 26b) eller gravegange (fig. 24a, 26a, c).

Flintindholdet varierer fra boring til boring og fra top til bund i de enkelte boringer. Den horisontale og vertikale fordeling er søgt belyst ved korrellation af de enkelte flintlag, men korrellationerne var for usikre på grund af flintlagenes indbyrdes lighed. Der er desuden optegnet kumulative kurver

Fig. 24: Bioturberede kalksten fra København Kalken. 24 a: Gravegange af Thalassinoides. Boring TUBA 122, kote $\div 44,2-\div 44,4$ m. 24 b: Gravegange, antagelig af Thalassinoides. Samme boring, kote $\div 31,7-\div 31,9 \mathrm{~m} .24 \mathrm{c}$ : Sammenkrøllede lag og gravegange af Thalassinoides. Boring TUBA 291, kote $\div 34,90-\div 35,05$. Forf. foto.

Fig. 24. Bioturbated limestones from the København Limestone. 24 a: Burrows produced by Thalassinoides. Borehole TUBA I22, 44.2-44.4 m below sea-level. 24 b: Burrows, possibly produced by Thalassinoides, from borehole TUBA 122, 31.7-31.9 m below sea-level. $24 \mathrm{c}$ : Crumpled beds and thalassinoid burrows. Borehole TUBA 291, 34.90-35.05 m below sea-level. Photograph by the author.

Fig. 25: Forkislet, uregelmæssigt lejret kalk og flintfyldte gravegange. Lerslirerne viser uensartet sammentrykning omkring hårde partier. Boring TUBA 122 , prøve 63 , kote $\div 50,9-\div 51,1 \mathrm{~m}$. Forf. foto.

Fig. 25: Silicified, irregularly bedded limestone and flint-filled burrows. Marly laminae demonstrate uneven compaction due to heterogeneous lithification. Borehole TUBA 122, 50.9-51.1 m below sea-level. Photograph by the author. 

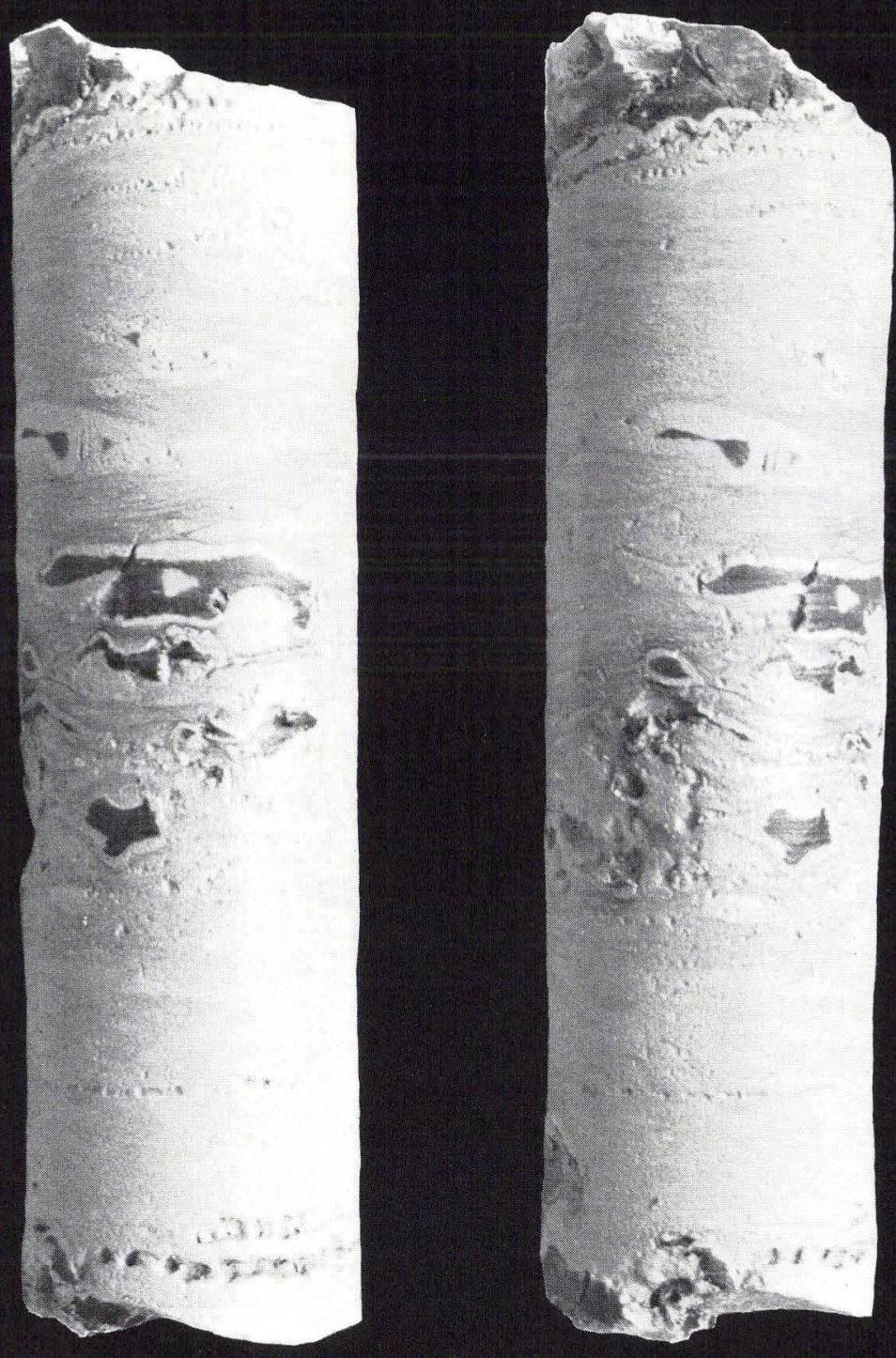


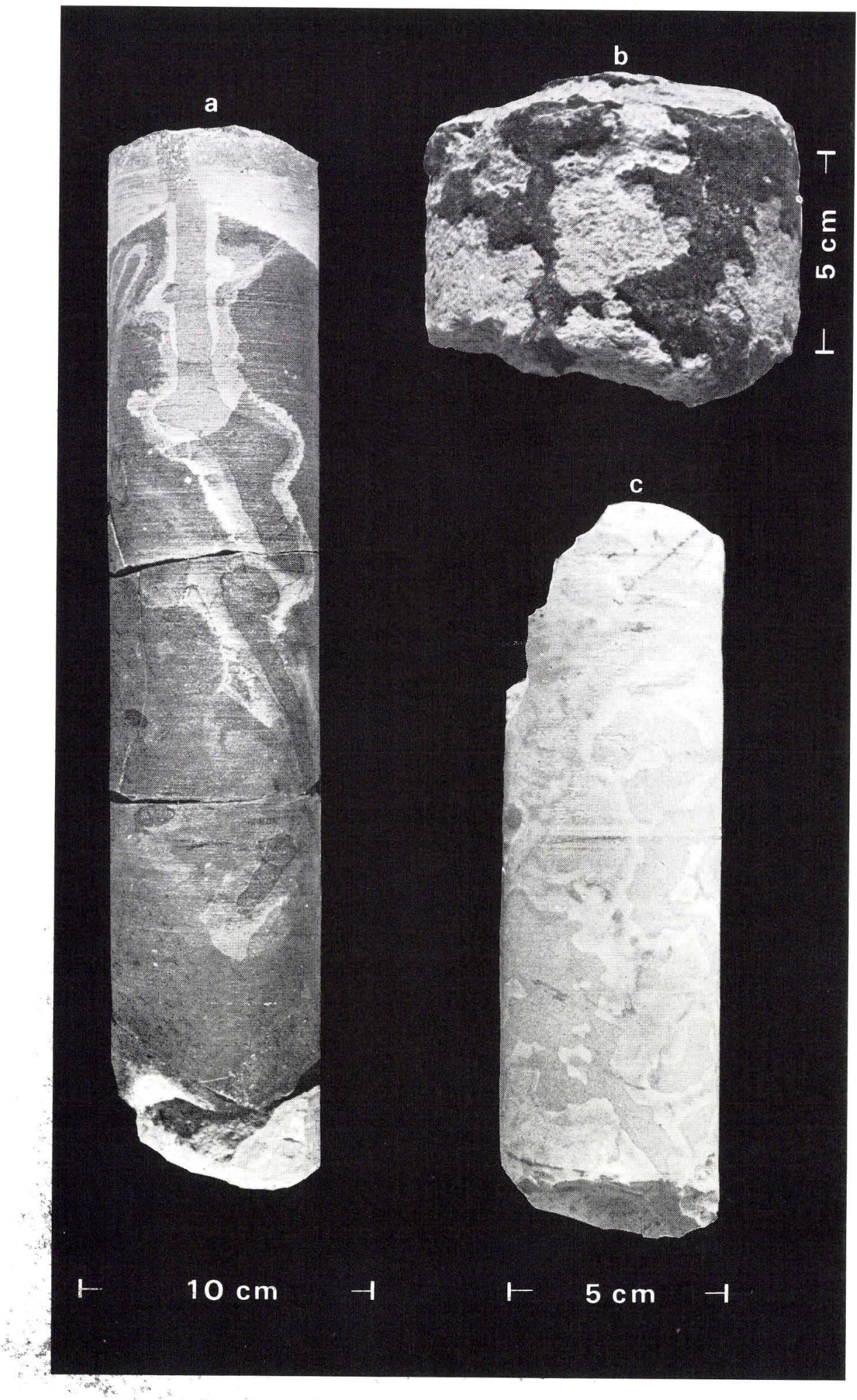


over flintfordelingen ned gennem de enkelte boringer, men kurverne kunne ikke korrelleres med sikkerhed. Betragter man et større område, kan der spores en tendens til, at den nedre del af København Kalken er mere flintrig end den $\emptyset v$ re del. Som et eksempel herpå anføres fig. 27, der viser flintindholdet i boringer på strækningen Højbro Plads - Kgs. Nytorv. Det er ikke undersøgt, om der består signifikante forskelle i flintmængden mellem forskellige dele af Københavnsområdet, men der er intet, som umiddelbart tyder herpå. På strækningen Ingerslevsgade - Rådhuspladsen indeholder de øverste 10 m af København Kalken 10-20\% flint med et gennemsnit på 14\%. På strækningen Rådhuspladsen-Højbro Plads varierer indholdet mellem $12 \%$ og $25 \%$ med et gennemsnit på $18 \%$. På samme strækning indeholder de øverste $20 \mathrm{~m}$ af kalken mellem $10 \%$ og $25 \%$ flint og på strækningen Højbro Plads-Kgs. Nytorv 10-23\%.

Boringerne på Saltholm yder intet væsentligt bidrag til belysningen af København Kalken, der kun blev truffet i en boring, bor. 12, på den nordvestlige del af øen i nærheden af de gamle kalkbrud. Den lille lagserie, fra 0-4,95 m under terræn, indeholdt grå, flintførende kalksandskalk, som var hærdnet til svagt hærdnet. De nederste 0,5 m af København Kalken er tyndbænket med fossilrige lagflader. Der findes en glideflade 10-15 cm over grænsen til bryozokalkenheden.

Ifølge Bang (In: Mertz et al. 1969, Bang \& Stenestad 1970a, 1970b, Bahn-

Fig. 26: Forkisling. 26 a: Toppen af København Kalken ved Hovedbanegården. Øverst en lille erosionsrest af Lellinge Grønsand, som tillige udfylder gravegange (Thalassinoides) i kalken. Bemærk de successive forkislingsgrænser og de to små horisontale forskydninger øverst i kernen over flintlaget. Boring TUBA 191, prøve 33, kote $\div 9 \mathrm{~m}$. O. Neergaard Rasmussen foto.

26 b: Hærdnet kalksandskalk med uregelmæssig, sort flint, antagelig replacerede gravegange. Boring TUBA 123, prøve 63 , kote $\div 47,9-\div 48,0 \mathrm{~m}$. Forf. foto. $26 \mathrm{c}$ : Forkislet, bioturberet kalksandskalk (Thalassinoides) fra toppen af den bioturberede København Kalk. Boring TUBA 741 , prøve 65 , kote $\div 19,05-\div 19,20 \mathrm{~m}$. Forf. foto.

Fig. 26: Silicification. 26 a: The uppermost part of the Kobenhavn Limestone at the Central Station. At the upper end of the core a thin cover of Lellinge Greensand is preserved. Thalassinoid burrows, infilled with material from the superimposed Lellinge Greensand, demonstrate successive silicifications. Note the two small horizontal displacements near the top at the core right over the flint. Borehole TUBA 191, $9 \mathrm{~m}$ below sea-level. $26 \mathrm{~b}$ : Indurated calcarenitic limestone with irregularly formed black flint (possibly replaced thalassinoid burrows). Borehole TUBA 123,47.9-48.0 m below sea-level. $26 \mathrm{c}$ : Silicified, bioturbated (Thalassinoides), calcarenitic limestone from the topmost part of the bioturbated Kobenhavn Limestone. Borehole TUBA 741, 19.05- 19.20 m below sea-level. Photographs by O. Neergaard Rasmussen (26a) and the author.

Fig. 27: Flintfordelingen i boringerne TUBA 36-44 på strækningen Højbro Plads-Kongens Nytorv.

Fig. 27: Flints in the boreholes TUBA 36-44. 


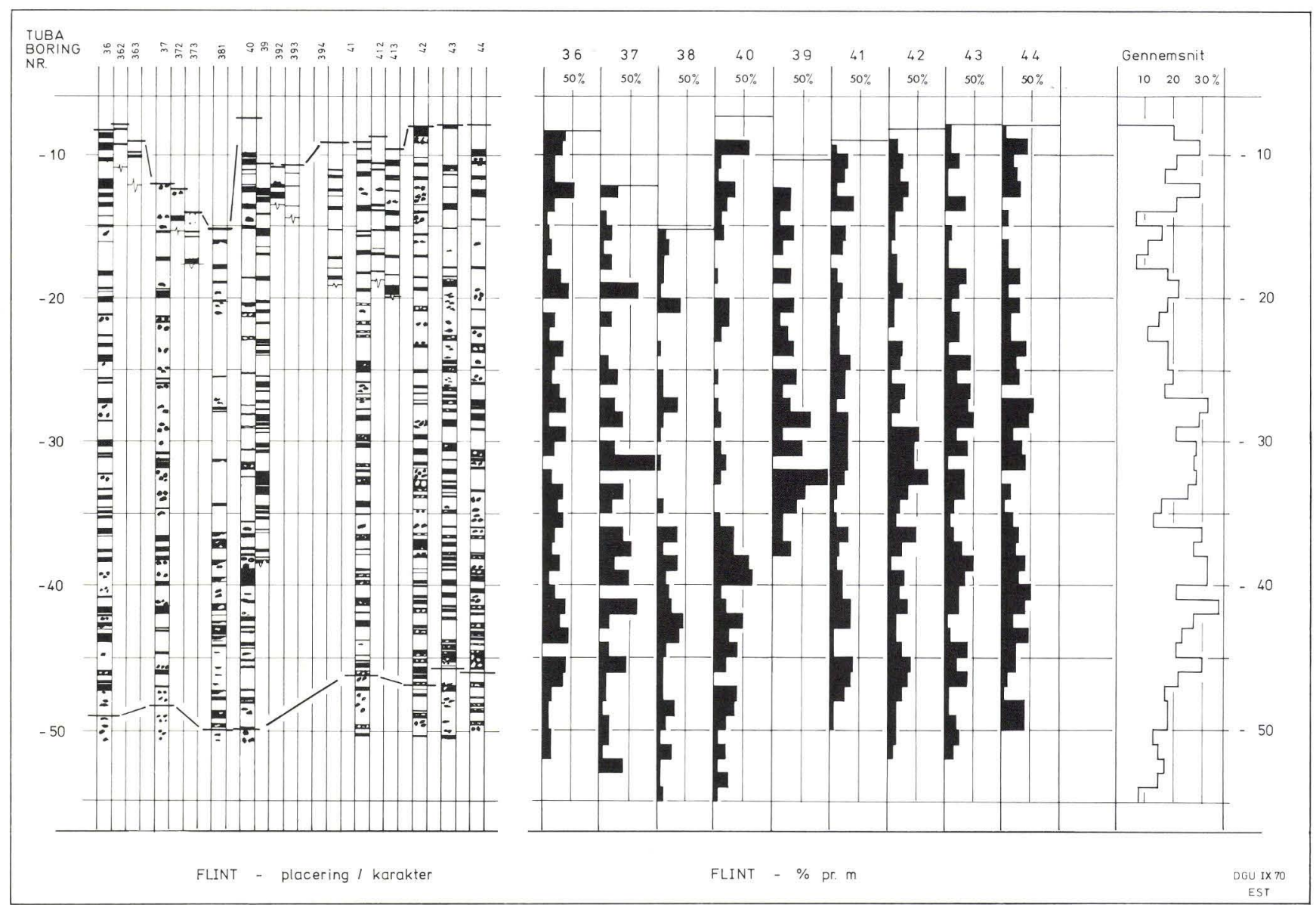




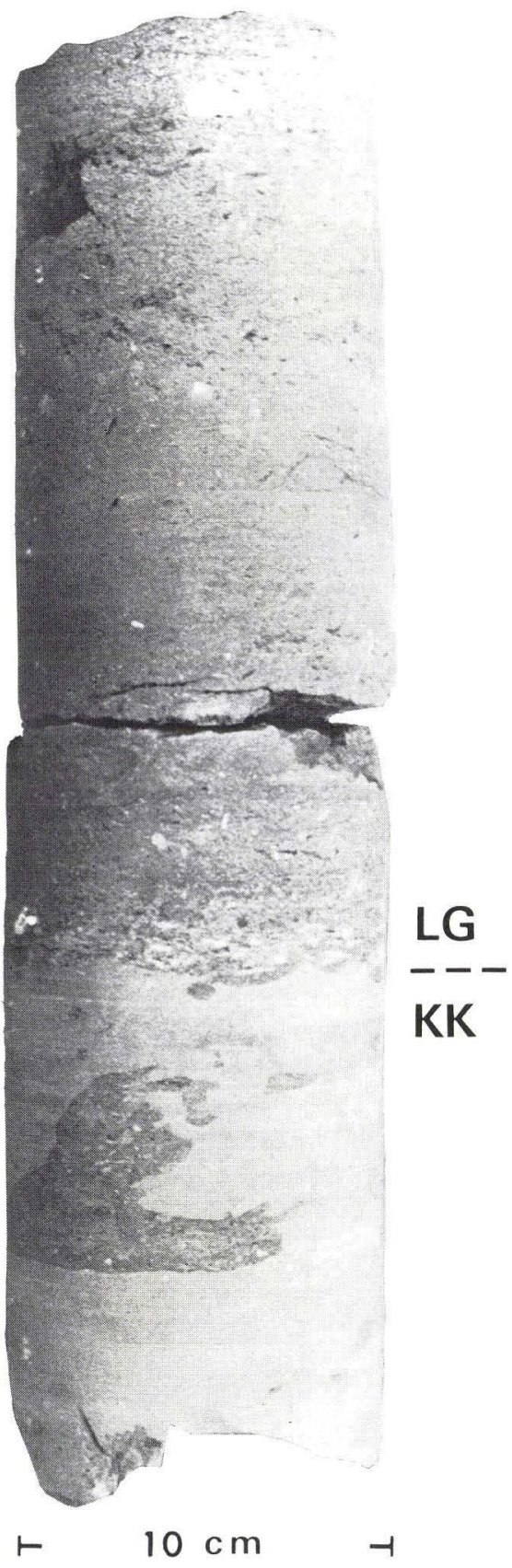

Fig. 28: Grænsen mellem København Kalk (KK) og Lellinge Grønsand (LG), der tillige udfylder en gravegang af thalassinoid type, i boring TUBA 402 nær Vestre Gasværk. Top af KK: kote $\div$ $7,97 \mathrm{~m}$. Forf. foto.

Fig. 28: The boundary between the Kobenhavn Limestone $(K K)$ and the Lellinge Greensand $(L G)$, also filling a thalassinoid burrow, in borehole TUBA 402. Top of KK: $7.97 \mathrm{~m}$ below sea-level. Photograph by the author. 
son et al. 1969, 1970, 1971, 1972) kan København Kalken henføres til Pyramidina crassa-Lagena sp. 18 zonen, som kendes fra yngre danien forskellige steder i Danmark. København Kalken kan deles i en øvre zone, domineret af Subbotina triloculinoides og S. klintholmensis, og en nedre zone, der domineres af Globoconusa daubjergensis (Bang 1969, fig. 4). I G. daubjergensis zonen findes en subzone med Turborotalia sp. 4, som med stor regelmæssighed optræder ca. 8-10 m over bryozokalkenhedens øvre grænse (fig. 11-20).

Kobenhavn Kalk

Ny formation

Navn: København Kalk

Typeområde: Øst-København

Typelokalitet: Citybaneboring 13 (TUBA 13), DGU-arkiv nr.: 201.3080, intervallet kote $\div 11,1 \mathrm{~m}-\div 50,25 \mathrm{~m}$. Profilbeskrivelsen findes i tabel 2 .

Diagnostiske karakterer: Slamkalksten med omkring 20-30\% kalksand og kalkfinsand og med et lille indhold af ler, der giver kalkstenene en lys grå farve. Karakteristisk er en svagt udviklet lagdeling og et stort indhold af flint, som danner sammenhængende lag. Der findes dog også uregelmæssigt lejret kalk og uregelmæssigt formede flintkonkretioner.

Granser og kontakter: København Kalken overlejrer bryozokalkenheden og overlejres af Lellinge Grønsand. Den nedre grænse er typisk markeret af en hardground. Fra Saltholm kendes et konglomerat fra den nedre grænse, men dette er ikke et generelt træk. Den øverste del af København Kalken er udformet som en hardground eller eventuelt som et flintlag. Umiddelbart over den $\varnothing v$ re grænseflade finder man mange steder Lellinge Grønsandets bundkonglomerat (Echinodermkonglomerat eller Øvre Craniakalk i ældre litteratur), fig. 28. Det kan dog mangle. Den $\emptyset$ vre og nedre grænseflade er vist på kortene, fig. 39 og 43.

Geografisk udbredelse: Dele af Nordøstsjælland, Amager og det sydlige Øresund, nord, vest og syd for Saltholm samt på den nordvestlige del af øen.

Lagmagtighed: Størrelsesorden ca. 40 m. Typelokaliteten: 39,2 m. Svanemøllen: mindst 44 m. (Observerede lagmægtigheder på ca. 47 m i Svanemølleområdet kan evt. være tektonisk betingede). 


\begin{tabular}{|c|}
\hline $\begin{array}{c}\text { Mellem Paleoccen } \\
\text { (Middle Paleocene) }\end{array}$ \\
Nedre Paleocœn \\
Danien \\
(Lower Paleocene) \\
(Danian) \\
Maastrichtien \\
(Maastrichtian)
\end{tabular}

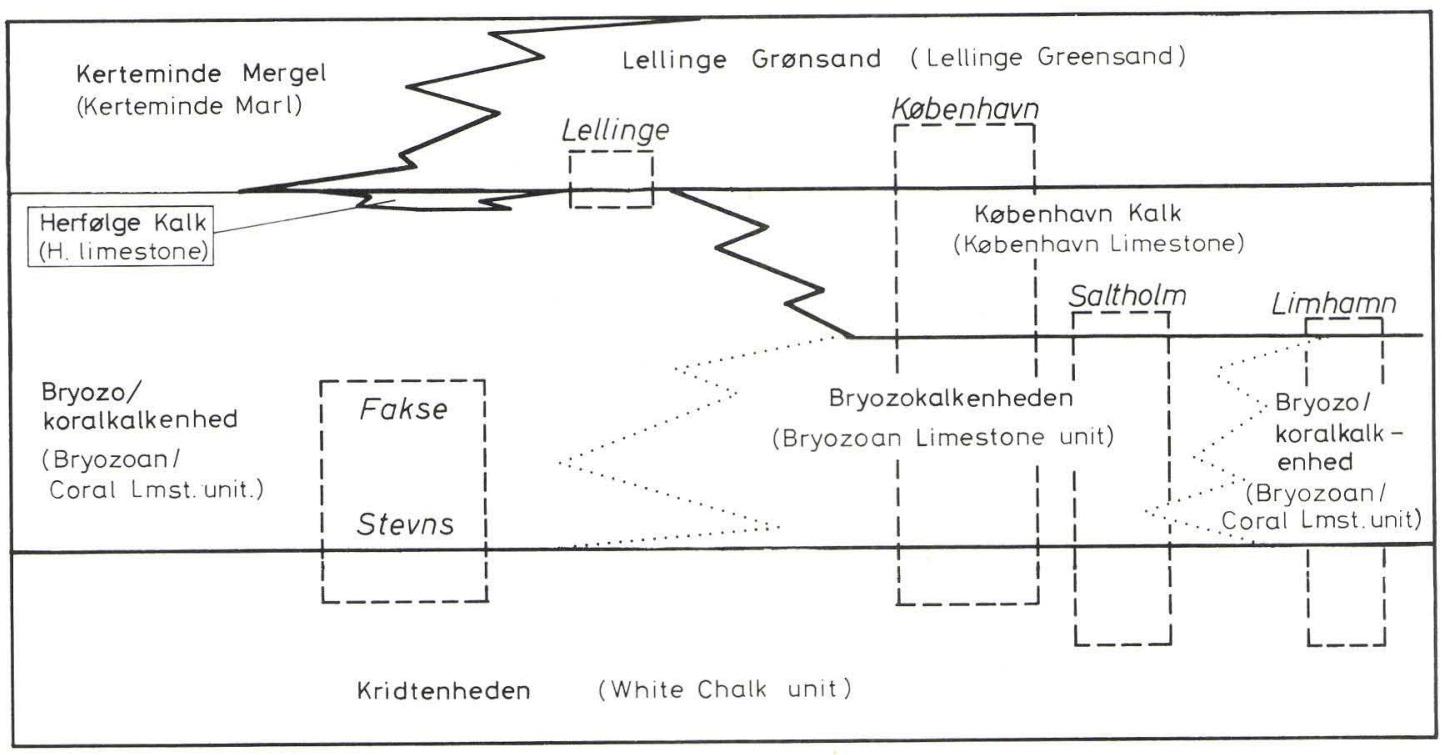

Fig. 29: De københavnske formationer og deres formodede korrelationer.

Fig. 29: The rock-stratigraphic units of the Copenhagen area and their presumed correlations. 
Alder: Danien. Globoconusa daubjergensis zonens øvre del, Subbotina triloculinoides subzonen (Troelsen 1957).

Korrellationer: København Kalken kan biostratigrafisk korrelleres med danien ved Herfølge, Klintholm og Hjerm samt dele af danien i Nordsøen (Bang, pers. medd.). Lithologisk kan København Kalken korrelleres med de skånske forekomster af kalksandskalk (fig. 29).

\section{Selandien}

Mellem paleocæn

Øverst i den prækvartære lagserie finder man i dele af Københavnsområdet glaukonitiske kalksten og mergeler, som på grundlag af bl.a. von Koenens (1885) studier af Vestre Gasværk faunaen er henført til mellem paleocæn. Rosenkrantz (1924a) indførte, på grund af usikre korrellationer med udlandet, etagebetegnelsen selandien for lagene over København Kalken og under det askeførende ældre tertiære ler, d.v.s. lag yngre end danien og ældre end nedre eocæn. Det skal dog bemærkes, at en del af de askelag, som forekommer i ældre tertiær i Nordsøen, muligvis er af paleocæn alder (Dinesen et al. 1976). Selandien'ets relationer til den internationale stratigrafi er stadig noget usikre (se Hansen 1968), hvorfor betegnelsen selandien bibeholdes.

De københavnske selandienaflejringer anses for sammenhørende med de tilsvarende dannelser ved Lellinge. Den formationelle enhed, som disse erosionsrester tilhører, er ikke formelt defineret. Dog betragtes Lellingeforekomsten som en art ty pelokalitet (Sorgenfrei 1957 p. 19), selv om et typeprofil ikke er udpeget.

De københavnske grønsandsaflejringer er så godt beskrevet, blandt andet af Rosenkrantz (1920 a og senere afhandlinger) og Gry (1935), at der blot savnedes en beskrivelse af lagseriens øvre og nedre grænseflade, inden en formel definering kunne finde sted. Citybaneboringerne har nu muliggjort, at disse grænsefladers beliggenhed kan beskrives ret nøje for de københavnske forekomsters vedkommende, og København vælges derfor som referencelokalitet.

\section{Lellinge Grønsand}

Emenderet formation.

Navn: Lellinge Grønsand.

Typeområde: Den østlige og centrale del af Sjælland. 
Typelokalitet: Lellinge, Skovhus Vænge.

Referenceområde: Området fra Københavns Sydhavn til Sct. Jørgens Sø.

Referenceprofil: Vestre Gasværk. Det af Rosenkrantz (1930 pp. 381-384) beskrevne profil, mellem kote $\div 5,95 \mathrm{~m}$ og $\div 10,17 \mathrm{~m}$. Med hensyn til forholdene på typelokaliteten henvises til Gry (1935) og Sorgenfrei (1957).

Diagnostiske karakterer: Glaukonitprægede kalksten og mergeler.

Granser og kontakter: Lellinge Grønsandet overlejrer København Kalken og overlejres selv af kvartærlag. Den nedre grænse findes i referenceområdet ved oversiden af en hardground eller et flintlag øverst i København Kalken. Den $\varnothing v r e$ grænse er en erosionsoverflade, frembragt af istidens gletschere og smeltevandsstrømme. Den $\varnothing v r e$ og nedre grænseflade er vist på kortene fig. 35 og 39 .

Geografisk udbredelse i København: Fra Sydhavnen til Øresundskysten.

Lagmagtighed: Den maksimale lagmægtighed kendes ikke, da kun erosionsrester er bevaret. Den kan muligvis overstige $6 \mathrm{~m}$ (Gry 1935), men i citybaneboringerne er den største iagttagne lagtykkelse ca. $4 \mathrm{~m}$.

Alder: Mellem paleocæn, nedre selandien, Globorotalia angulata biozonen (Hansen 1968).

Korrelationer: Det er uvist, hvordan Lellinge Grønsandet kan korrelleres med aflejringer uden for Midt- og Østsjælland. I de vestligere egne af landet er konglomerat og grønsand kun sparsomt udviklet, og formationen synes at mangle i store dele af Jylland-Fyn samt det vestligste Sjælland (Dinesen et al. 1976). Det er sandsynligt, at Lellinge Grønsandet vil kunne korrelleres med dele af Kerteminde Mergelen (fig. 29). Uden for Danmark er det nærliggende at sammenligne med de ældre tertiære lag ved Klagshamn og Ystad. Brotzen (1948 p.29) angiver, at den københavnske paleocæne lagserie (d.v.s. Lellinge Grønsandet) ligner den svenske og indeholder næsten samme makro- og mikrofauna. Hansen (1968) påpeger, at foraminiferfaunaen i det mørke ler ved Vestre Gasværk i det væsentlige er identisk med den fauna, Brotzen (1948) beskriver fra Klagshamn.

Lellinge Grønsandets bjergarter er petrografisk undersøgt af Gry (1935). De omfatter ved København: Bundkonglomerat, grønsandskalk, grønsand og grønsandsler, der kort kan karakteriseres således: Bundkonglomeratet og grønsandskalken består hovedsageligt af kantslidte skalrester og kalksandspartikler fra nederoderede ældre lag. Dette materiale er sammenkittet af 


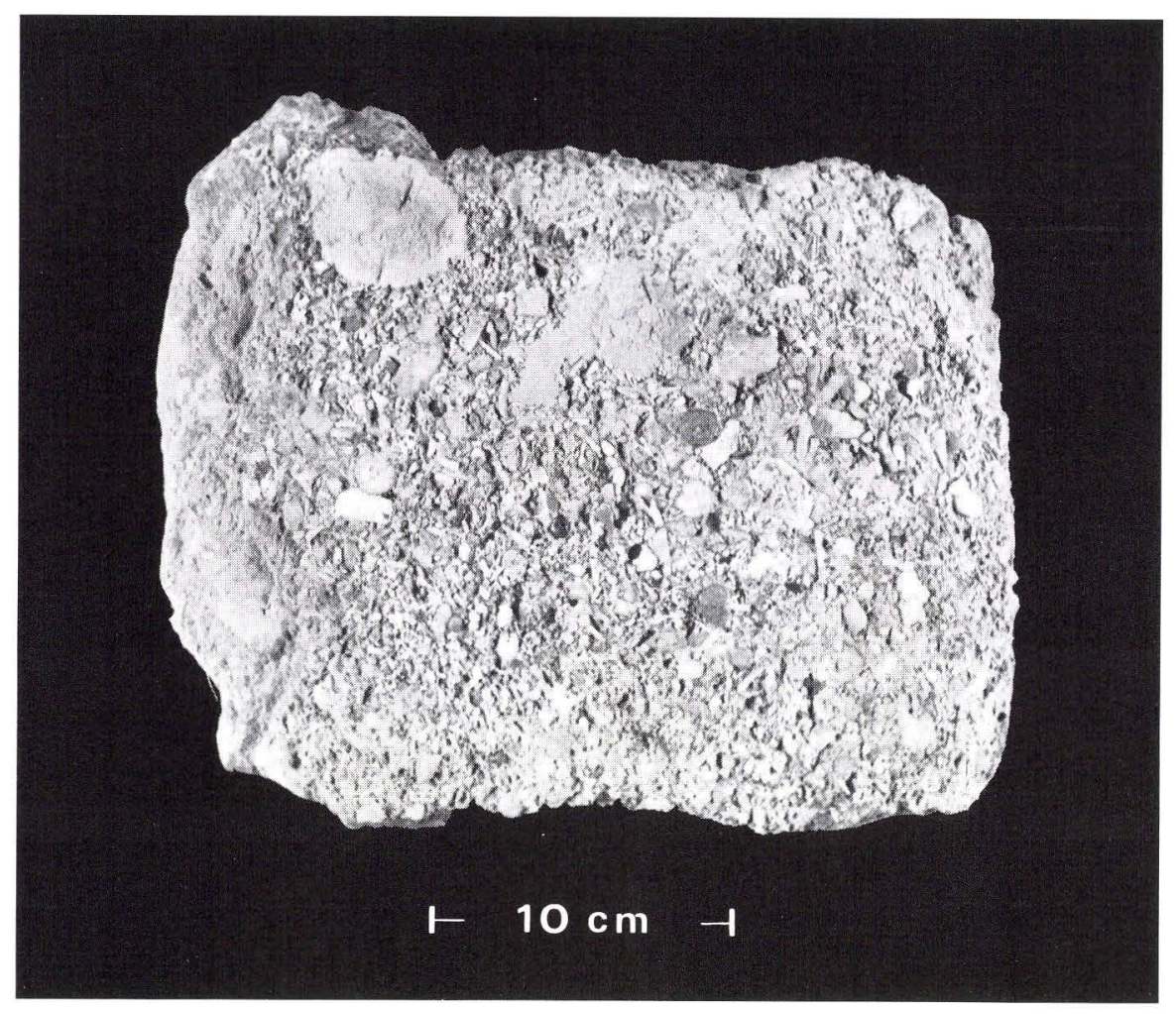

Fig. 30: Lellinge Grønsandets bundkonglomerat. Frilagt lagflade. Svanemølletunnelen, skakt A. O. Neergaard Rasmussen foto.

Fig. 30: The basal conglomerate of the Lellinge Greensand. Bedding plane seen from above. The Svanemolle tunnel, shaft A. Photograph by O. Neergaard Rasmussen.

grovkrystallinsk kalkspat til grågrønne, hårde, glaukonitiske kalksten med et kalkindhold på over $90 \% \mathrm{CaCO}_{3}$ (fig. 30).

Grønsandet er en glaukonitholdig sandaflejring, bestående af kalkkorn, kalkslam, kvartskorn, ler, svovlkis og skalrester. Flintlignende forkislinger forekommer. Kalkindholdet er højt i den nederste del af lagene, men aftager opefter til omkring $50 \%$. Til grønsandet henregnes glaukonitisk finsand og silt.

Gronsandsleret er i mekanisk henseende en silt- og finsandsholdig leraflejring. Indholdet af $\mathrm{CaCO}_{3}$ er imidlertid så stort, at bjergarten i kemisk henseende er en typisk mergel. Indholdet af glaukonit giver den sortgrå bjergart en grønlig farvetone. 


\section{Kvartær}

Den københavnske lagserie afsluttes med et forholdsvis tyndt dække af kvartære dannelser, som i det følgende omtales kort. Fremstillingen er hovedsagelig baseret på Milthers (1935), Mertz et al. (1969) og Bahnson (1973).

\section{Glaciale aflejringer}

Moraneaflejringer. Den dominerende moræneaflejring inden for området er moræneler, og man har kun undtagelsesvis mødt de andre, mindre lerholdige morænedannelser. Dette skyldes dog muligvis til dels boreprocessen, idet morænegrus, morænesand og lerfattigt moræneler let ødelægges ved spuling under borearbejdet. Det er derfor muligt, at der i visse tilfælde er anført gruseller stenlag i boreprofilerne, hvor man ved udgravning måske ville finde morænesand eller -grus.

Moræneleret i citybaneboringerne er i overvejende grad uforvitret og kalkholdigt med et lerindhold på 15-25\%, hvilket er relativt meget. Lokalt indgår meget fede lerarter i moræneaflejringerne. En del af dette lermateriale kan eventuelt hidrøre fra skånske jurabjergarter, som er indarbejdet i morænen. Som et eksempel herpå kan nævnes en prøve af rødliggråt, ret fedt ler fra en boring i Turesensgade. Leret, som havde en vis habituel lighed med Pankarplagene, indeholdt i grovsandfraktionen brudstykker af glaukonitisk, finglimmer- og siltholdig, koksgrå lersten, samt silt-, finglimmer- og kulflageholdige grå lersten af en type, der optræder flere steder i den skånske jura, bl.a. i Gantofta (» Ammonitbænken«), i Hälsingborglagene og i Skromberga lagserien. Desuden optræder brudstykker af en bjergart, som har stor lighed med chamositsandstenen fra Vallåkra.

Flere steder i Københavnsområdet ses partier af glaukonitsand i moræneaflejringerne. De stammer sandsynligvis fra Lellinge Grønsand, der findes faststående i området.

Mertz (In: Mertz et al. 1969) bemærker om moræneleret i Ingerslevsgade Rådhuspladsområdet, at det ved sin hårde næsten sintrede konsistens leder tanken hen på de isbelastede moræneaflejringer, man har truffet andre steder $\mathrm{i}$ landet, f.eks. under interglaciale aflejringer inden for Weichselisens område. Den kan tolkes som en bundmoræne.

Smeltevandsaflejringer. Citybaneundersøgelserne har vist, at den hidtidige opfattelse af de københavnske glaciallag, som bestående af to morænelers-

Fig. 31: Tidligere og nuværende (postglaciale) vandområder. Efter Bahnson (1973).

Fig. 31: Holocene watercovered areas. Dotted line: Centerline of the investigation area for the underground railway. Dashed line: $3 \mathrm{~m}$ level. According to Bahnson (1973). 


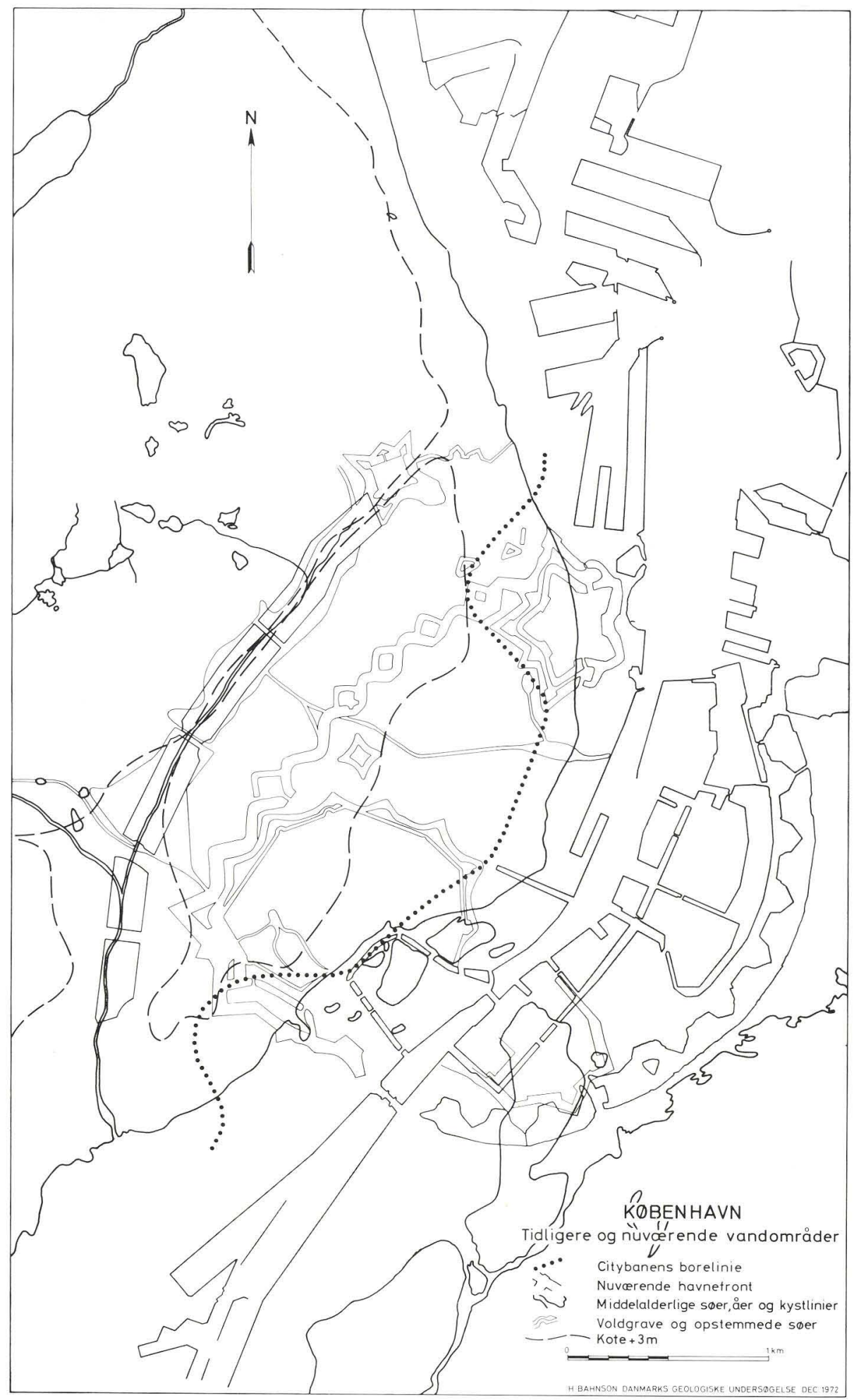




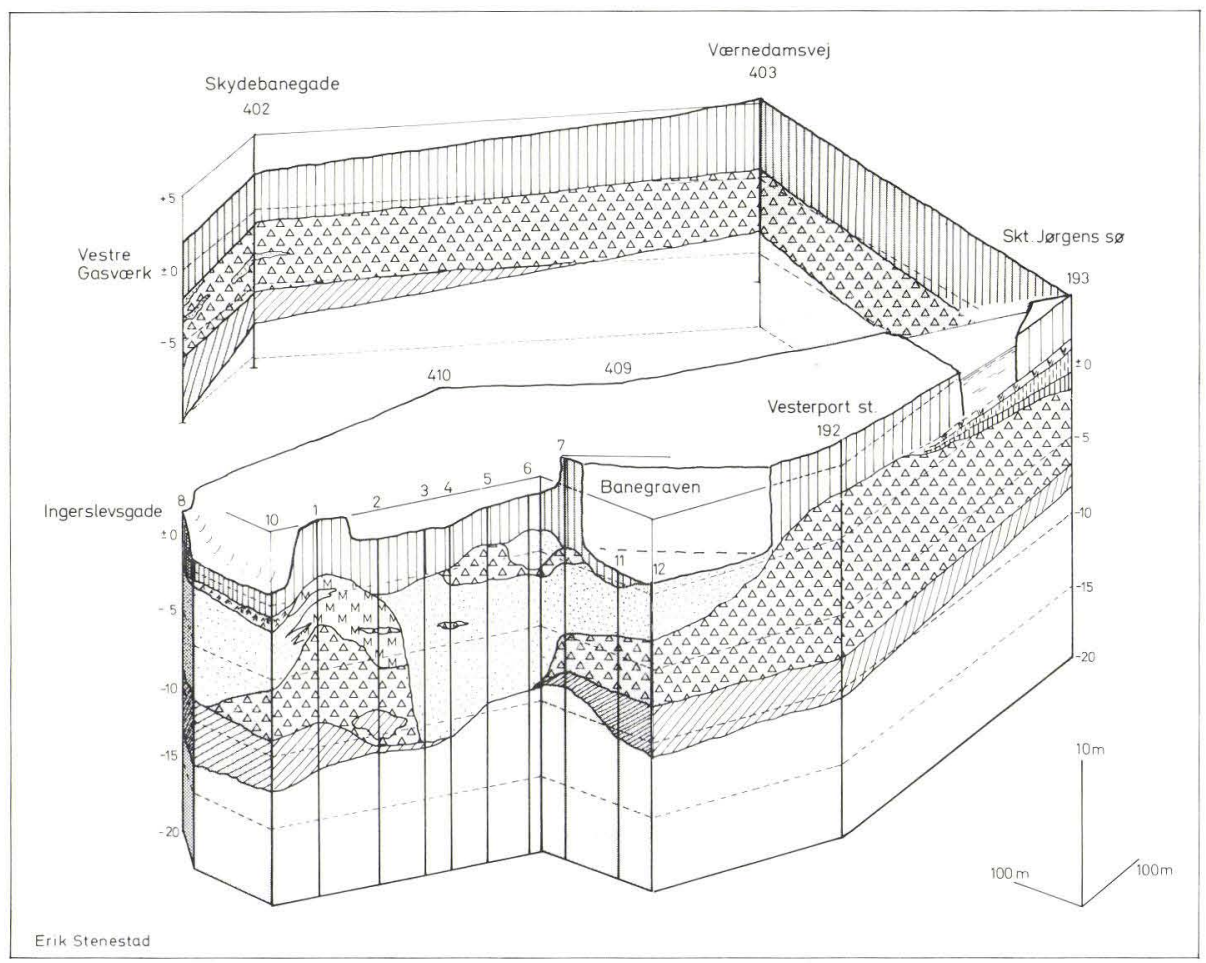

Fig. 32: Blokdiagram visende Lellinge Grønsandets referenceområde vest for Hovedbanegården. Referenceprofilet er benævnt »Vestre Gasværk «. En smeltevandsdal skærer sig gennem den nedre morænelersbænk og Lellinge Grønsandet (vist med skråskravering) til København Kalken (ved boringerne TUBA 3-6). Bemærk den øvre morænelersbænk i boringerne TUBA 4-7. Søernes dal og det tidligere kystområde ved Ingerslevsgade indeholder svagt udviklede postglaciale lagserier. Signaturer: se fig. 5 .

Fig. 32: Blockdiagram of the reference area of the Lellinge Greensand. The reference profile is named "Vestre Gasvark". A glacial valley cuts down through the lower till-bed and the Lellinge Greensand (oblique hatching) to the subjacent Kobenhavn Limestone (boreholes TUBA 3-6). Note the upper till-bed in boreholes TUBA 4-7. At the lake (St. Jørgens S $\emptyset$ ) and near the former sea-shore (Ingerslevsgade) postglacial sediments are to be found. Legend: see fig. 5 .

bænke med et mellemliggende sandlag, stort set er rigtig, idet der dog er områder, hvor den øvre eller den nedre morænelersbænk mangler. De glaciale smeltevandssedimenter er stærkt vekslende i kornstørrelse fra lag til lag, men er inden for de enkelte lag ofte velsorterede. Sand- og grusfraktionerne dominerer. Kun undtagelsesvis træffes smeltevandssilt og -ler.

Fig. 33: Fyldlagets tykkelse. Efter Bahnson (1973).

Fig. 33: The thickness of the earth fill. According to Bahnson (1973). 


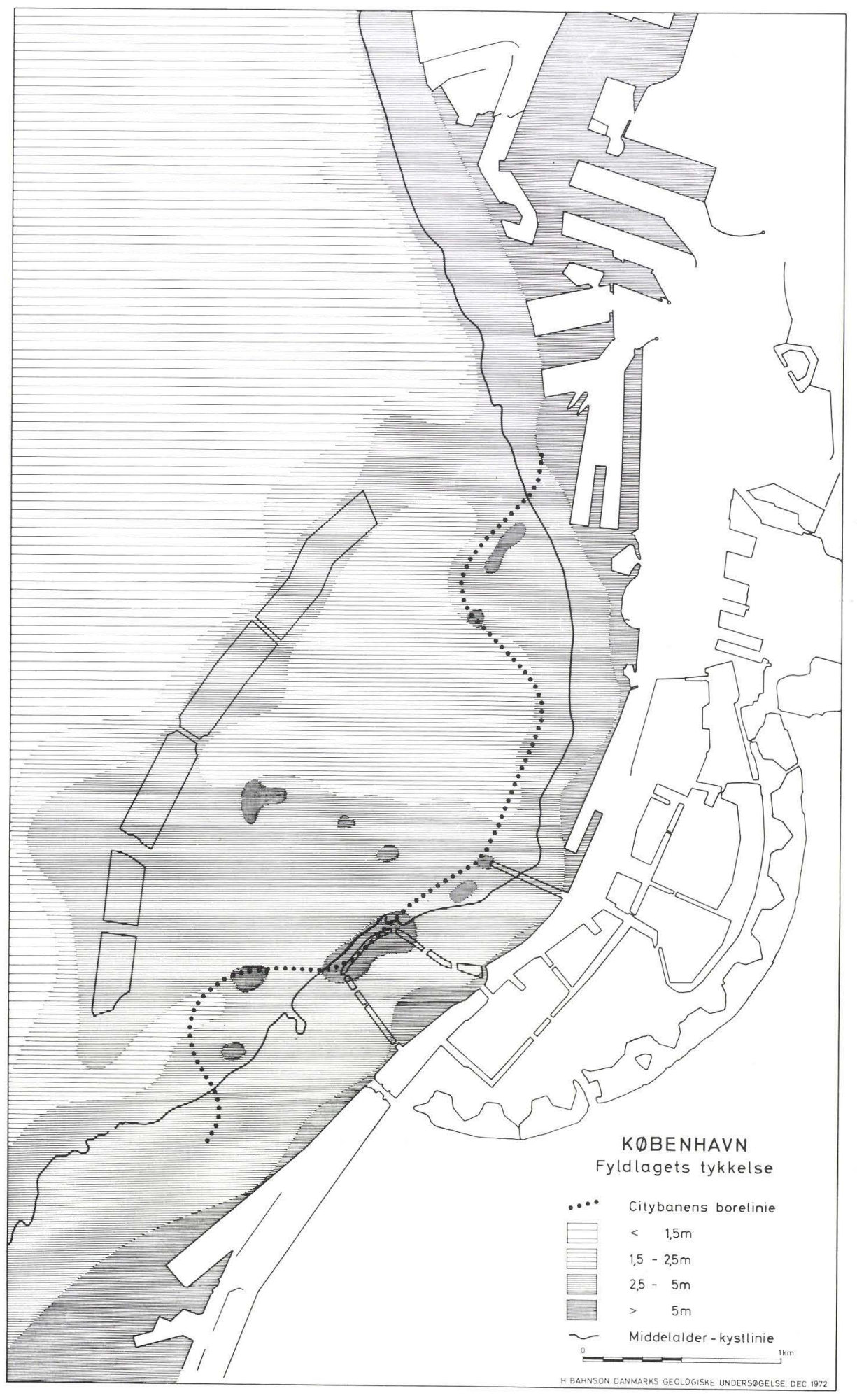




\section{Senglaciale aflejringer}

Senglaciale smeltevandsaflejringer optræder underordnet i det område, citybaneundersøgelsen dækker. Tynde lag af senglaciale nedskylssedimenter findes derimod flere steder i området. Det største sammenhængende område med nedskylsler, -silt og -sand er lavningen ved Skt. Jørgens s $\varnothing$ - Sortedamssøen (fig. 32).

\section{Postglaciale aflejringer}

Som vist på kortet, fig. 31, har der i det indre København været nogle mindre vandløb og søer, hvori postglaciale sedimenter er afsat. Blokdiagrammet, fig. 32, viser eksempler på sådanne lagfølger. I boringerne finder man ikke marine gytjeaflejringer af betydning. Sikre postglaciale, marine lag er i intet tilfælde truffet $\mathrm{i}$ boringer, hvis kvartærlag når op over kote \pm 0 .

\section{Fyld og omgravede jordlag}

De øverste 2-3 m af lagserien i de indre bydele består af bløde, muld- og fyldprægede jordlag med affald og bygningsrester fra 800 års byhistorie. Bahnson (1973) gør opmærksom på, at fyldlagets tykkelse stort set afspejler byens udvikling, idet 2,5 m kurven på fyldkortet (fig. 33) omtrent svarer til grænsen for det ældste København, medens 1,5 m kurven indeslutter byudvidelserne i 1600-tallet. Særligt tykke fyldlag findes i havnen og i de gamle voldgrave, hvor de heterogene, stenede og gytjeholdige fyldlag nogle steder er op mod $10 \mathrm{~m}$ tykke.

\section{Sammenfatning. Lagserien og dens tilblivelseshistorie}

Den lagserie, som er beskrevet i de foregående afsnit, er vist i skematisk form i fig. 34. Lagserien afspejler en serie af regressioner og transgressioner $i$ maastrichtien, danien og selandien, efterfulgt af en landperiode, der omfattede resten af tertiæret, og afsluttet af glaciation og delvis transgression af området i kvartærtiden. Begivenhedsforløbet har formodentlig været omtrent således:

Den store regression i slutningen af maastrichtien medførte også i Københavnsområdet en afbrydelse af sedimentationen. Den øverste del af kridtlagene blev udviklet som hardgrounds, men detaljerne i udformningen af maastrichtien-danien grænsen viser, at der har hersket noget varierende lokale forhold. I boring 12 på Saltholm er der således tre sedimentationsafbrydelser (hardgrounds) i nærheden af maastrichtien-danien grænsen. De to 


\begin{tabular}{|c|c|c|c|c|}
\hline \multicolumn{2}{|c|}{ Kronostratigrafi } & Lithostratigrafi & Bjergarter & Lagtykkelser \\
\hline \multirow{2}{*}{$\stackrel{\vec{E}}{\vec{E}}$} & \multirow{2}{*}{ Postglacialtid } & & Fyld & $1,5-10 \mathrm{~m}$ \\
\hline & & & Sand, silt, ler, gytje og tørv & fă meter \\
\hline 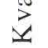 & Senglacialtid & & Nedskylssand og -ler & få meter \\
\hline & Glacialtid & & Moræneler og -sand/Smeltevandsler og -sand & $10-15 \mathrm{~m}$ \\
\hline \multirow{3}{*}{ 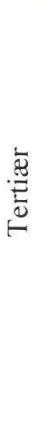 } & $\begin{array}{l}\text { Mellem } \\
\text { Paleocærı } \\
\text { (Selandien) }\end{array}$ & $\begin{array}{l}\text { Lellinge } \\
\text { Grønsand }\end{array}$ & $\begin{array}{l}\text { Grønsandsler } \\
\text { Grønsand } \\
\text { Grønsandskalk } \\
\text { Konglomerat }\end{array}$ & $0-6 \mathrm{~m}$ \\
\hline & \multirow{2}{*}{$\begin{array}{l}\text { Nedre } \\
\text { Paleocæn } \\
\text { (Danien) }\end{array}$} & $\begin{array}{l}\text { København } \\
\text { Kalk }\end{array}$ & $\begin{array}{l}\text { Kalksandskalk, regelmæssigt lejret, med flintlag } \\
\text { Kalksandskalk, bioturberet, med flint } \\
\text { Kalksandskalk, lerpræget, overvejende regelmæs- } \\
\text { sigt lejret, med flintlag }\end{array}$ & $40-45 \mathrm{~m}$ \\
\hline & & $\begin{array}{l}\text { Bryozokalk- } \\
\text { enheden }\end{array}$ & $\begin{array}{l}\text { Bryozokalk og slamkalk med flint } \\
\text { Slamkalk }\end{array}$ & $50-65 \mathrm{~m}$ \\
\hline 豪 & Maastrichtien & Kridtenheden & Slamkalk (kridt)-med flintknolde & $\begin{array}{l}\text { ikke } \\
\text { gennemboret }\end{array}$ \\
\hline
\end{tabular}

Fig. 34: Stratigrafi og bjergarter. For English version: see fig. 60.

er af tidlig danien alder, medens sedimentationsafbrydelsen ved selve grænsen kan være fra danien eller allerøverste maastrichtien. Forholdene i Saltholm boring 12 tyder på, at der i slutningen af maastrichtien og begyndelsen af danien har været bevægelser i Saltholm-Limhamn strukturen (p. 82-85). Efter maastrichtienregressionen fulgte en transgressionsperiode, hvorunder der aflejredes kalksten af danien alder. Den nederste del af danienlagserien er især præget af slamkalksten, som stedvis har en betydelig lighed med det underliggende kridt. Opefter præges kalken af skeletrester efter bryozokolonier, som på dette tidspunkt dannede bevoksninger på havbunden. I bryozokalklagserien indgår underordnede lag og partier af kalksand og mergel, aflejret mellem bryozobevoksningerne. Deres tilstedeværelse antyder strømme og slumping på havbunden, men det generelle billede tyder dog på rolige sedimentationsforhold. Dette støttes af den petrografiske unders $\emptyset$ gelse af kalksten fra boringen TUBA 13 (Nielsen 1976), der viser, at bryozokalkenhedens bjergarter i hvert fald i hovedsagen er akkumuleret i et lavenergi miljø, dvs. under forhold, hvor strøm og bølgeslag har spillet en mindre rolle.

På grænsen mellem bryozokalkenheden og København Kalken indtrådte en sedimentationsafbrydelse, som i næsten alle boringer markeres af en hardground i toppen af bryozokalken. Almindeligvis findes kalksandsfyldte gravegange mindst $1 / 2-1 \mathrm{~m}$ ned i bryozokalken. Efter sedimentationsafbrydel- 
sen kom en ny transgression, hvorunder København Kalken blev afsat. Den består overvejende af kalksandskalk og kan underinddeles i tre lithologiske enheder, med status af informelle members. Udformningen af det nederste member varierer noget inden for området, hvor forskellige sedimentationsog erosionsforløb formodentlig er realiseret samtidig. Lagseriens opbygning og variationer inden for korte afstande gør det sandsynligt, at sedimentationen har fundet sted $\mathrm{i}$ et forholdsvis lavvandet område. Nielsen (1976) har påvist mikroboregange i fire niveauer i TUBA 13, bl.a. i den nederste del af København Kalken. Disse mikroboregange stammer muligvis fra alger og viser i givet fald, at vanddybden var forholdsvis beskeden.

Højere oppe i København Kalken er udviklingen derimod meget ensartet i hele området. Dette fremgår dels af de lithologiske forhold, dels af foraminiferfaunaerne. De rolige sedimentationsforhold under aflejringen af bryozokalkenheden, har formodentlig også rådet i store dele af København Kalkens sedimentationsperiode. Det mellemste member, den bioturberede København Kalk, er dannet under særlige sedimentationsforhold, som ophørte brat på et tidspunkt hen mod slutningen af København Kalkens sedimentationsperiode, idet overkanten af den bioturberede kalk danner en jævn, sammenhængende flade, som har kunnet kortlægges og benyttes som referensniveau ved vurderingen af strukturforholdene. Det øverste member af København Kalken er kraftigt bænket, og hårde og bløde lag veksler med massive flintlag. Kalken er langt mindre præget af gravegange end de underliggende lag. Den $\emptyset$ verste del af København Kalken er i alle boringer meget ensartet udviklet og svagt men regelmæssigt lagdelt, hvad der sammenholdt med den ensartede udvikling af foraminiferfaunaerne tyder på, at der har været rolige og ensartede sedimentationsforhold i hele området. Dog tyder de petrografiske forhold i de øverste ca. $8 \mathrm{~m}$ af København Kalken i boring TUBA 13 (Nielsen 1976) på, at området, eller dele deraf, hen mod slutningen af sedimentationsperioden har været noget mere præget af strøm og bølgeslag.

Den øverste del af København Kalken indeholder som omtalt stærkt maastrichtien prægede planktoniske foraminiferfaunaer (fig. 11-20). Tilsvarende forhold er iagttaget i Skåne (Brotzen 1945). Dette viser, at maastrichtienaflejringer blev eroderet, samtidig med at den øverste del af København Kalken sedimenteredes. Hvorfra det omlejrede maastrichtienmateriale stammer, kan vanskeligt afgøres. Malmøsænken (Brotzen 1945) er en mulighed. Her kan tillige peges på Køgebugt, hvor der findes højtliggende kridt i et strukturelt betinget område, som Rosenkrantz (1937) betegnede Valby-Stevns Horsten, og som ved nyere geofysiske undersøgelser (Baartmann \& Christensen 1975, pl. 3) har vist sig at hælde i nordlig retning fra Stevns mod København. Det er kendt, at der findes højtliggende kridt i Vejleåområdet ved Køgebugt, og nyere boringer ved Vallensbæk har påvist kridt mellem 
kote \pm 0 og $\div 10 \mathrm{~m}$, overlejret af bryozokalk og iøvrigt under omstændigheder, som gør det usandsynligt, at det skulle dreje sig om glaciale flager.

Nær slutningen af danienperioden ophørte aflejringen af kalksandskalk i Københavnsområdet, og der var en - formentlig ret kortvarig - sedimentationsafbrydelse, inden selandientransgressionen satte ind. Selandienhavet eroderede dele af havbunden, og i lavereliggende områder sammenskylledes glaukonitiske skalrestlag (bundkonglomerat og grønsandskalk). Over disse kalklag følger Lellinge Grønsandets sand-, silt-, mergelserie. Hvor grønsandskalken og konglomeratet mangler, overlejres danienkalken direkte af det glaukonitiske sand. Nogle steder er den øverste del af danienkalken og den nederste del af selandienaflejringerne først hærdnet et stykke ind i selandienperioden, idet der er set flere eksempler på, at gravegange gennemtrænger såvel selandienets bundkonglomerat som danienkalkens øvre hardground. Det er sædvanligvis glaukonitsand og ikke grønsandskonglomeratets grove skalrester, man finder i disse gravegange. Der findes også eksempler på, at gravegange er bevaret i flintlag, således i en boring ved Bernstorffsgade, hvor et $30 \mathrm{~cm}$ tykt flintlag (fig. 26 a) er kraftigt gennemsat af gravegange, som er fyldt med glaukonitsand og forkislet i flere omgange, hvad der fremgår af successive forkislingsgrænser. Flintdannelsen har således også strakt sig ind i selandien.

Lellinge Grønsandet afspejler en fortsat transgression af området, under hvilken der aflejredes stadig mere finkornede lag med aftagende kalkindhold og tiltagende lerindhold, som beskrevet af blandt andre Gry (1935). Der kendes ingen yngre tertiære aflejringer i Københavnsområdet, som må antages at have været hævet over havet i størstedelen af de sidste ca. 60 millioner år. Rosenkrantz fremsætter den tanke (1925, p. 16), at Valby-Stevns Horsten ved selandientidens begyndelse har været et landområde, som adskilte Gilleleje-København-Klagshamn området (med fjordkarakter) fra det vestlige område, Lellinge-Midtsjælland området (med mere åbne marine forhold).

Under istiden eroderede gletschere og smeltevandsstrømme den prækvartære overflade (fig. 35). Store dele af selandienaflejringerne blev borteroderet, og den øverste del af danienkalken blev mange steder udsat for erosion. Fig. 36 viser hovedtrækkene af prækvartæroverfladens morfologiske udformning på Københavnsegnen. De prækvartære lag ligger højt mellem Roskilde og Køge, og herfra strækker prækvartæret sig som et jævnt faldende bakkestrøg mod Øresund. Karakteristisk for området er de større og mindre dale, som skærer sig dybt ned i danienkalken: Søndersødalen, Vejleådalen og Rådhuspladsdalen, m.fl. De har sandsynligvis deres forudsætninger i sprækkezoner eller forkastningszoner i kalklagene. Den prækvartære overflades udformning er nærmere beskrevet i Stenestad (1973 b).

I København er der muligvis kun bevaret aflejringer fra den sidste nedis- 


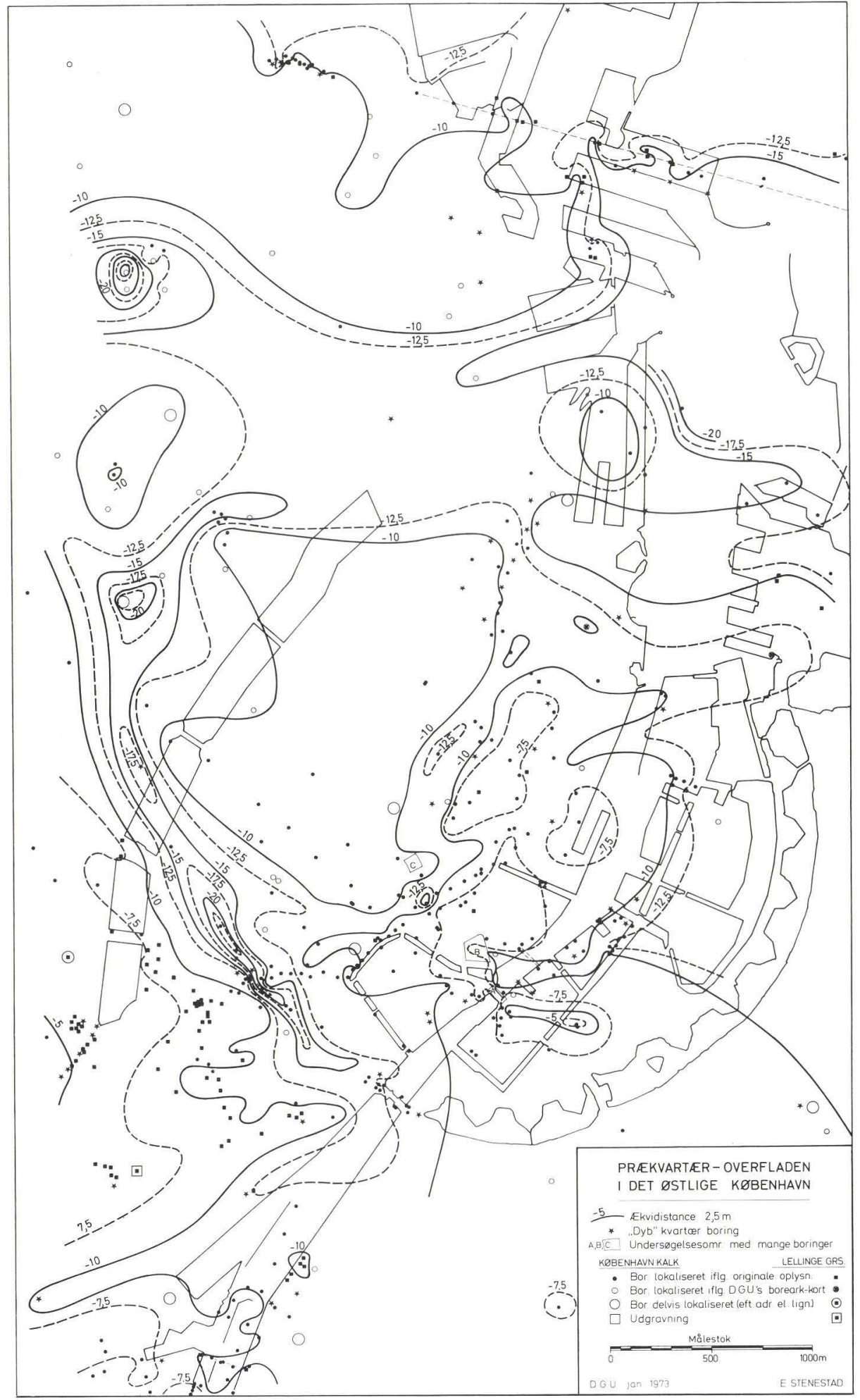




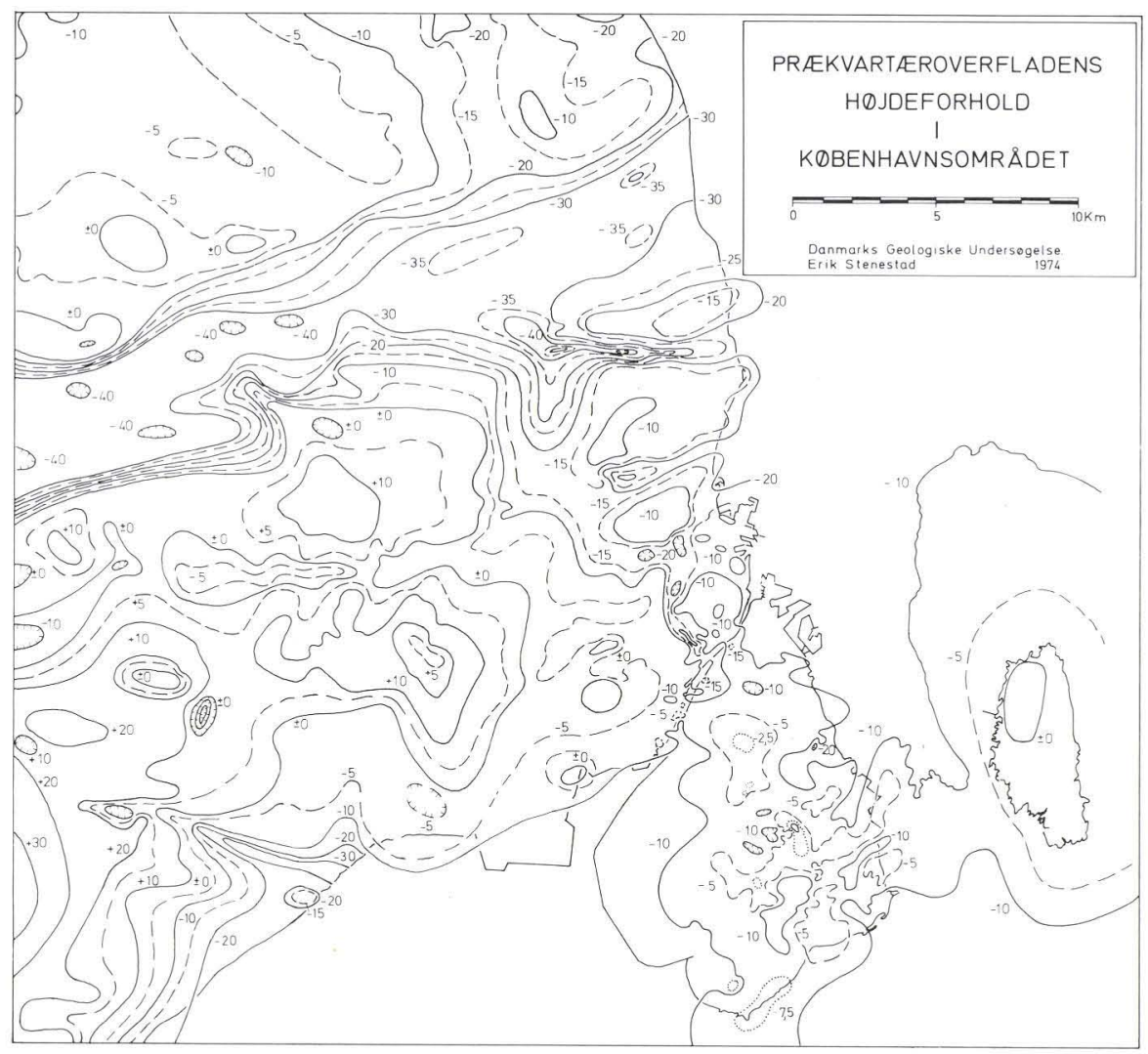

Fig. 36: Prækvartæroverfladen på Københavnsegnen. Koter i meter. Hovedsagelig sammenstillet på grundlag af Milthers (1935) samt upublicerede rapporter m.v. af L.J. Andersen (DGU), Inger Bang (DGU), O. Schøller Larsen (DSB) og E. Stenestad (DGU).

Fig. 36: The Pre-Pleistocene surface in Greater Copenhagen and adjacent areas. Altitudes in metres below sea-level. Compiled mainly from Milthers (1935) and unpublished reports and other informations from L.J. Andersen (DGU), Inger Bang (DGU), O. Scholler Larsen (DSB) and E. Stenestad (DGU).

ning, Weichselglaciationen. Lagserien, der er varierende opbygget, har en gennemsnitlig mægtighed på 10-15 m, men over dalene i kalkoverfladen findes kvartære lagtykkelser på $20-40 \mathrm{~m}$.

Mellem Søerne og havnen finder man praktisk taget ingen senglaciale

Fig. 35: Prækvartæroverfladen. Signaturer som på fig. 1. Stjerner viser relativt dybe boringer, som ikke har nået prækvartæret. Sorte firkanter markerer forekomster af Lellinge Grønsand. Fig. 35: The Pre-Pleistocene surface. Signatures as in fig. 1. Stars show rather deep boreholes, which did not reach Pre-Pleistocene deposits. Black squares indicate locations with Lellinge Greensand. 
aflejringer. Området har formentlig været et lavt bakkedrag, hvorfra en del af de senglaciale nedskylsaflejringer i Søernes dal og lavningen langs havnen er kommet. Fig. 31 viser denne situation.

I de sidste 10.000 år, postglacialtiden, er der dannet ler-, silt- og sandlag med plante- og skalrester samt gytje- og tørvelag. Store dele af Cityområdet har været dækket af Littorinahavet, hvis kystlinie har været ca. 3-3,5 m over det nuværende havniveau (Mertz, In: Mertz et al. 1969). På grænsen mellem fyld og original jord står visse gytjeaflejringer, som under opfyldningsarbejder er opblandet med fyldmaterialerne. 


\section{Strukturforhold}

Af hensyn til planlægningen af citybanebyggeriet var det vigtigt så tidligt som muligt at få kendskab til eventuelle større sprækkezoner i kalkundergrunden. Tilstedeværelsen af sprækker er vanskelig at bedømme selv med gode og tætliggende boringer, fordi boreprøvernes tilstand ikke entydigt viser mængden og størrelsen af sprækker nede i formationen. Ved hjælp af prøvepumpninger kan man få et indtryk af, om kalkstenene er »normalt « sprækkede, eller om der er meget store, vandførende sprækkesystemer tilstede. Der er en vis mulighed for, at større sprækkesystemer er knyttet til forkastningszoner, og hvis forkastningerne ikke er rent horisontale, kan de påvises ved stratigrafiske metoder. Ved bedømmelsen af strukturforholdene blev der benyttet to sæt referensflader, et lithologisk og et biologisk sæt, som først blev sammenholdt ved den endelige vurdering. På denne måde kontrollerede resultaterne hinanden. Som eksemplet, fig. 37, viser, var der god overensstemmelse mellem de biologiske og de lithologiske referensflader.

\section{Referensflader}

Forud for citybaneundersøgelsen eksisterede der ikke en stratigrafi for København Kalken, som var tilstrækkelig detaljeret til at muliggøre en vurdering af strukturforholdene i den næsten vandret liggende lagserie. Efterhånden som undersøgelsen skred frem, viste det sig muligt at arbejde med følgende lithologiske referensflader, ovenfra og nedefter: Selandien-danien grænsen, overkanten af bioturberet København Kalk og grænsen mellem København Kalk og bryozokalkenheden. Disse referensflader er beskrevet ovenfor. To biostratigrafiske referensflader var til rådighed, nemlig grænsen mellem $\emptyset$ vre og nedre foraminiferzone og Turborotalia sp. 4 subzonen. Disse flader er baseret på Inger Bangs zonering af København Kalken i citybaneboringerne (p. 54-57). 


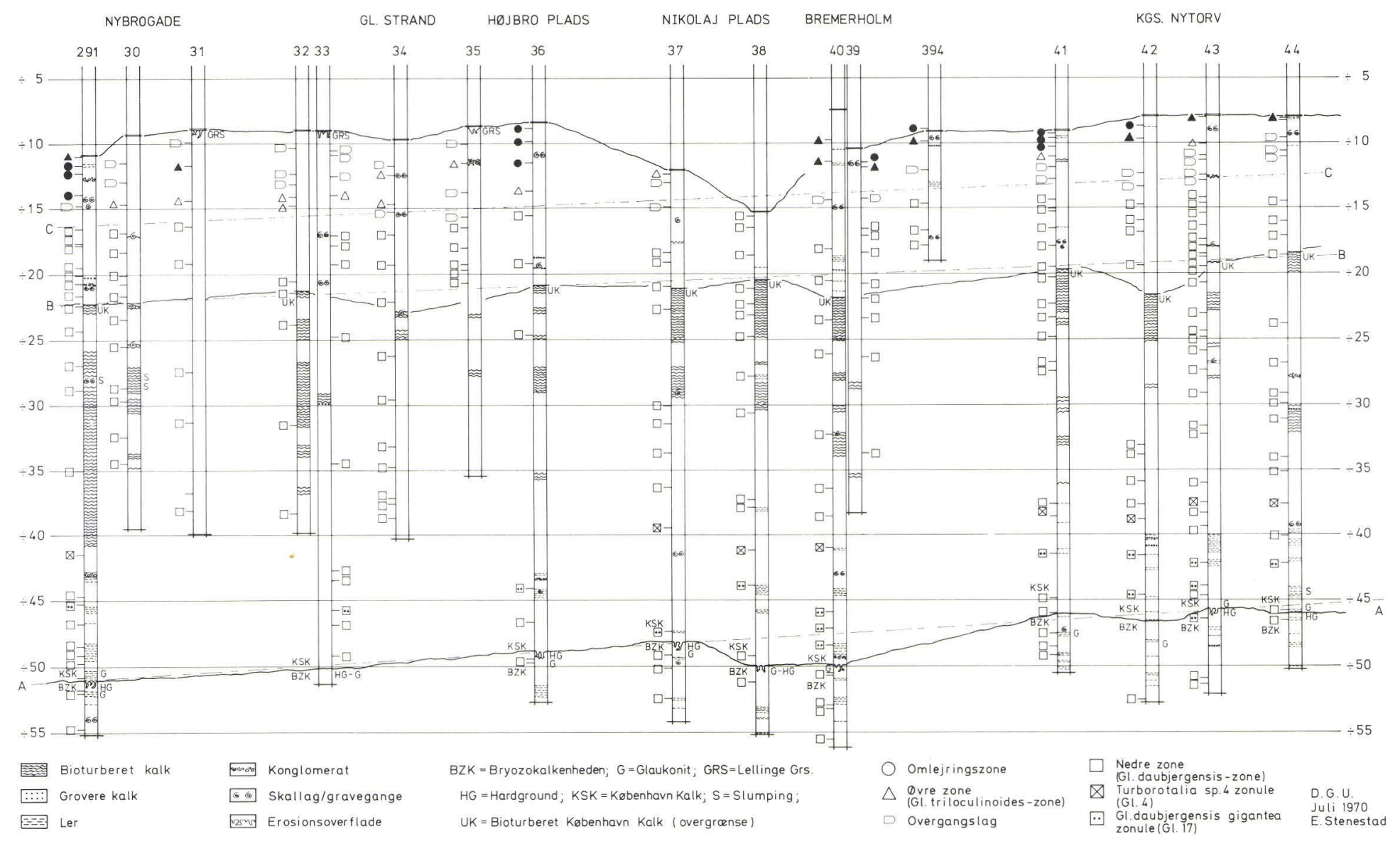




\section{Strukturkort}

Den arbejdsmodel, som blev benyttet ved fortolkningen af observationerne (d.v.s. af det sæt koter, som forelå for den enkelte referensflade), var baseret på den antagelse, at Københavns yngste prækvartære lag var praktisk taget vandrette, men at der kunne findes såvel svage foldninger som små vertikale forkastninger. Blandt andre har Rosenkrantz (1937) og Rosenkrantz og Rasmussen (1960) omtalt sådanne svage foldninger, ondulationer, der er af laramisk alder (dvs. fra ældre tertiær). Brotzen (1945, p. 42 n.) anfører også et eksempel på laramiske tektoniske bevægelser i området, idet dele af Malmø-sænken er blevet så skråtstillet, at øvre maastrichtien overlejres direkte af lag fra $\varnothing v r e$ danien. Øvre maastrichtien foraminiferer er ifølge Brotzen (1945) aldrig fundet på sekundært leje i nedre og mellem danien, men derimod ret ofte i $\varnothing v$ re danien. Det samme er tilfældet i Øst-København, hvor Bang har vist, at omlejrede maastrichtien foraminiferer kun findes øverst i København Kalken (fig. 11-20).

Med hensyn til forkastninger i området vidste man, at Øst-København var nedforkastet $\mathrm{i}$ forhold til vestegnen (Rosenkrantz 1925, 1937), og der var stærke indicier på tilstedeværelsen af forkastninger i Øresund (Sorgenfrei 1959). Desuden vidste man, at Limhamn-Saltholm var strukturelt højtliggende (Brotzen 1940), og at der formodentlig fandtes en forkastning mellem Saltholm og Kastrup (Larsen 1966). Fig. 38 er en skematisk sammenstilling af nogle af de elementer, der indgår i det strukturelle billede af de øvre prækvartære lag i regionen.

Ved udtegningen af strukturkortene, fig. 39-43, blev det fors $\varnothing g t$ at tegne det fladest mulige relief, for, om muligt, at fastholde billedet af praktisk taget vandret liggende lag. Hældning og strygning for alle tre-boring kombinationer blev beregnet og kurveforløbet lagt i overensstemmelse hermed. I de områder, som var meget tæt belagt med oplysninger, fik kurverne, på grund af det flade relief, et meget kompliceret forløb, medens andre områder, med færre oplysninger, fik et mere glat kurvebillede. På de enkelte kort er vist beliggenheden af de boringer, der var til rådighed for kurvetegningen.

Det viste sig, at observationerne bekræftede forventningen om, at lagene er ganske svagt foldede. Nogle steder var der problemer, som fandt den enkleste løsning igennem antagelsen af tilstedeværelsen af en forkastning. Disse for-

Fig. 37: Lithostratigrafiske og biostratigrafiske referensflader på strækningen Nybrogade-Kongens Nytorv. Efter Bang og Stenestad (In: Bahnson, Bang og Stenestad 1970).

Fig. 37: Lithostratigraphic and biostratigraphic reference levels in boreholes TUBA 291-44. Notice the remarkable agreement between the levels $A, B$ and C. According to Bang and Stenestad (In: Bahnson, Bang and Stenestad 1970). 


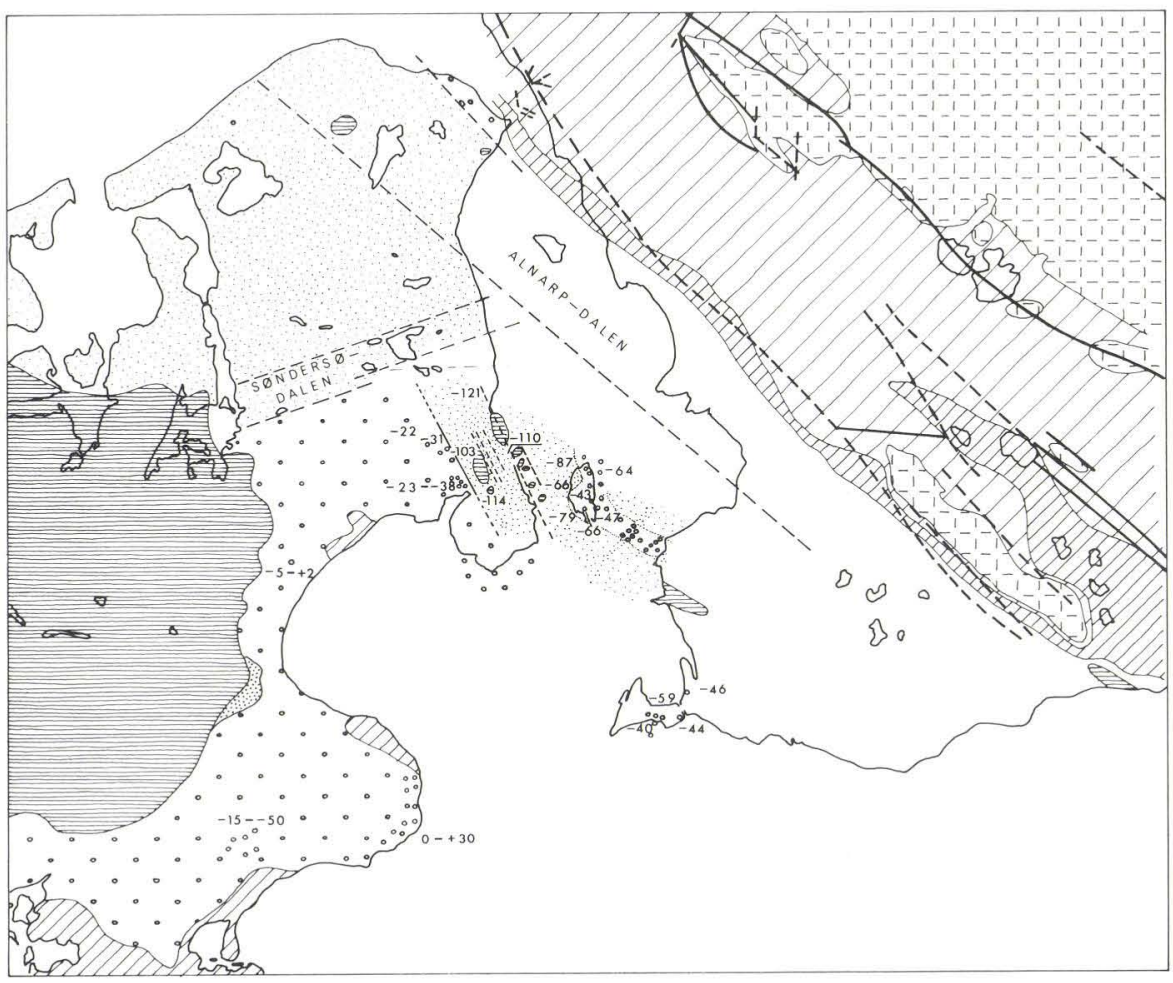

STRUKTURFORHOLD I ØRESUNDSREGIONEN

SIGNATURFORKLARING

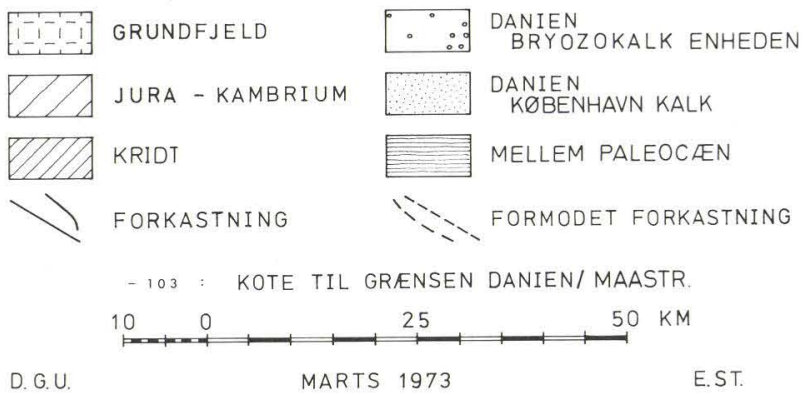

Fig. 38: Strukturforhold i Øresundsregionen. Efter Stenestad (1973 a). Sammenstillet på grundlag af Larsen (In: Larsen et al. 1968), Nathorst (1887), Rosenkrantz (1937), Sorgenfrei (1959), Sorgenfrei \& Berthelsen (1954), Ødum (1971) og egne undersøgelser.

Fig. 38: Some structural elements in the region around the Sound. According to the present author's opinion the Cretaceous and Danian limestones are slightly folded along axes roughly parallel to the Fenno-Scandian Borderzone, i.e. nordwest-southeast. The folded limestones have later been subjected to small-scale faulting. After Stenestad (1973 a). Compiled from Larsen (In: Larsen et al. 1968), Nathorst (1887), Rosenkrantz (1937), Sorgenfrei (1959), Sorgenfrei \& Berthelsen (1954), Ødum (1971) and the authors personal investigations.

Fig. 39: Strukturkort: Grænsefladen danien-selandien. Efter Stenestad (1973 a).

Fig. 39: Structural map: The reference level Danian-Selandian. According to Stenestad (1973 a). 


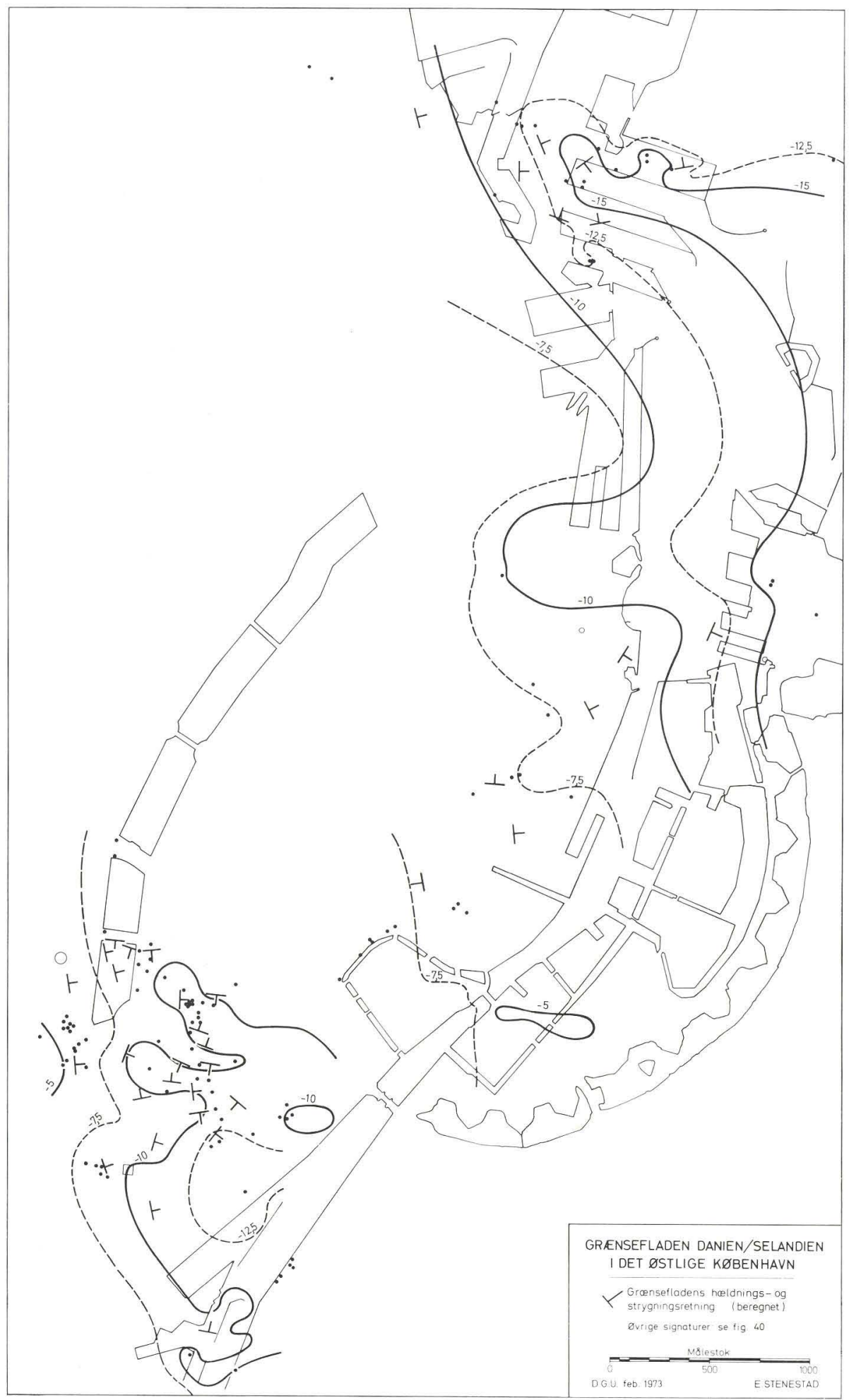




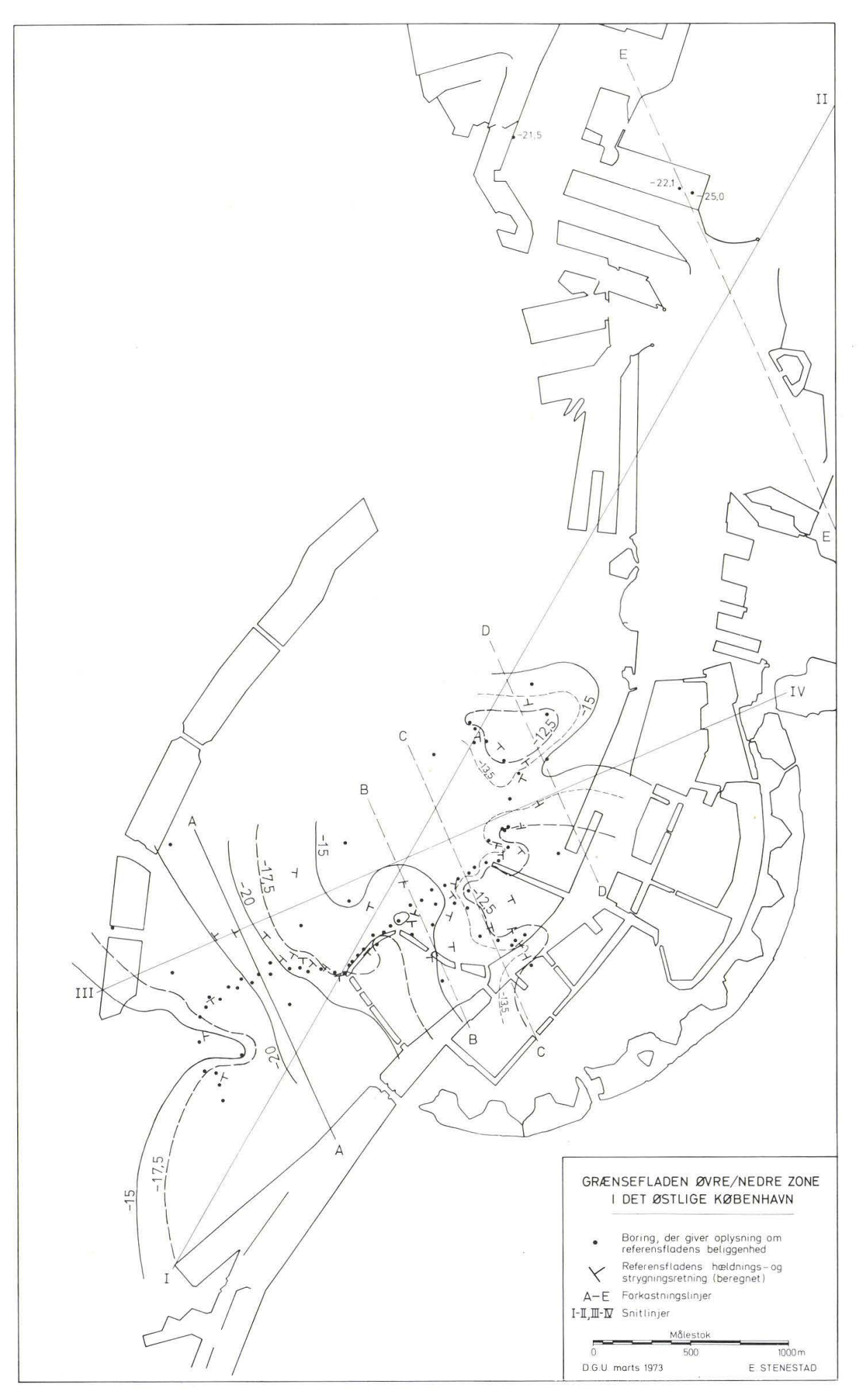


kastninger er vist som rette linier, trukket parallelt med Carlsbergforkastningen. De er benævnt A-E.

\section{Diskussion og konklusion}

Ved hjælp af strukturkortene kan man fremstille vertikale snit, som de fig. 44 og 45 viste. Vertikalsnittene kan tjene som illustration af forfatterens opfattelse af de strukturelle forhold i Øst-Københavns øvre prækvartære dannelser: Kridtenheden, bryozokalkenheden samt de nederste få meter af København Kalken er ganske svagt foldet. De maksimale laghældninger er ca. 1:200. I praksis er lagene altså meget nær vandrette. Den svage foldning viser sig som en lille ophvælvning af kalklagene under den indre by og som flade lavninger i områderne ved Sydhavnen og Svanemøllen. Det forhold, at de yngste kalklag ligesom de ældre er svagt bølgende, kan opfattes som resultat af jævn pålejring, som følger underlagets form, idet der ser ud til at ske en vis udjævning af relieffet opefter i lagserien. Deformationen må således have fundet sted inden aflejringen af de yngste kalklag. De svagt foldede kalklag er gennemsat af nogle små forkastninger med vertikale springhøjder på indtil 5-6 m. Det ser ud til, at højdeforskellene aftager opefter i lagserien, hvad der må betyde, at forkastningerne har været áktive flere gange i løbet af det tidsrum, i hvilket København Kalken blev dannet. Forkastningerne i Nicolaj Plads kvarteret (B og C) og ved Grønningen (D) har muligvis ikke ramt de $\emptyset$ verste 6-8 $\mathrm{m}$ af kalken. Derimod er det sandsynligt, at forkastningerne ved H.C. Andersens Bd. (A) og i Svanemølle området (E) også går igennem de øverste kalklag og således er yngre end danien.

Fig. 40: Strukturkort: Grænsefladen mellem Subbotina triloculinoides-zonen (»øvre zone «) og Globoconusa daubjergensis-zonen (»nedre zone«) som defineret af Bang (In: Bahnson, Bang og Stenestad 1970). Efter Stenestad (1973 a).

Fig. 40: Structural map: The border level between the Subbotina triloculinoides zone and the subjacent Globoconusa daubjergensis zone sensu Bang (In: Bahnson, Bang and Stenestad 1970). In the Globoconusa daubjergensis acme zone of Bang the zone species comes to at least 60 $\%$ of the planktonic forams. Through a transition zone, which is less than $2 \mathrm{~m}$ in thickness, Globoconusa daubjergensis disappears completely in the Copenhagen boreholes. As stressed by Hansen (1968 p. 282) the boundary between the G. daubjergensis zone and the G. angulata zone (i.e. the Danian-Selandian boundary) must be placed at the appearence of G. angulata and not at the extinction of the G. daubjergensis group. Map according to Stenestad (1973 a).

Fig. 41: Strukturkort: Top af den bioturberede København Kalk. Efter Stenestad (1973 a). Fig. 41: Structural map: Top of the bioturbated Kobenhavn Limestone. According to Stenestad (1973 a). 


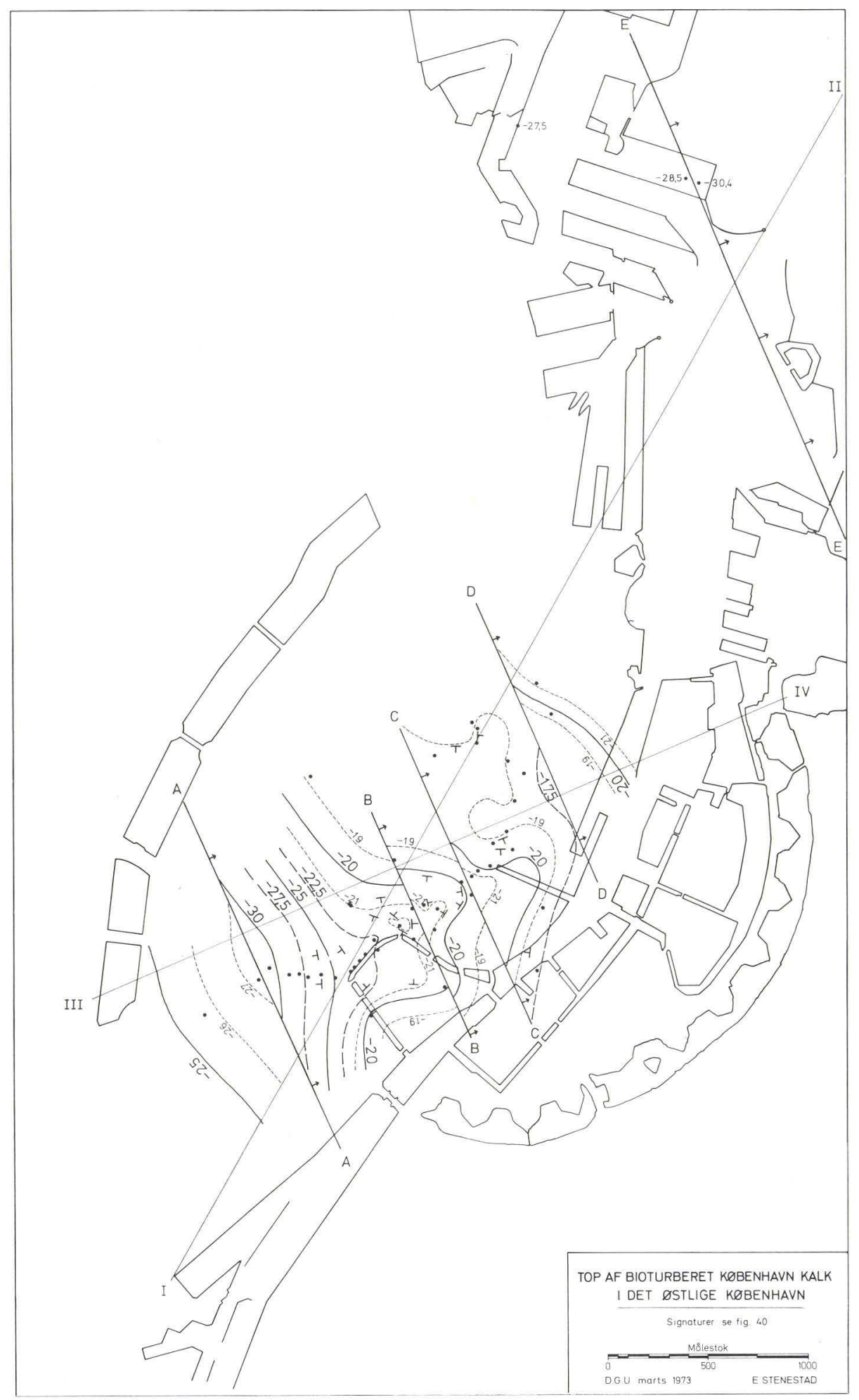




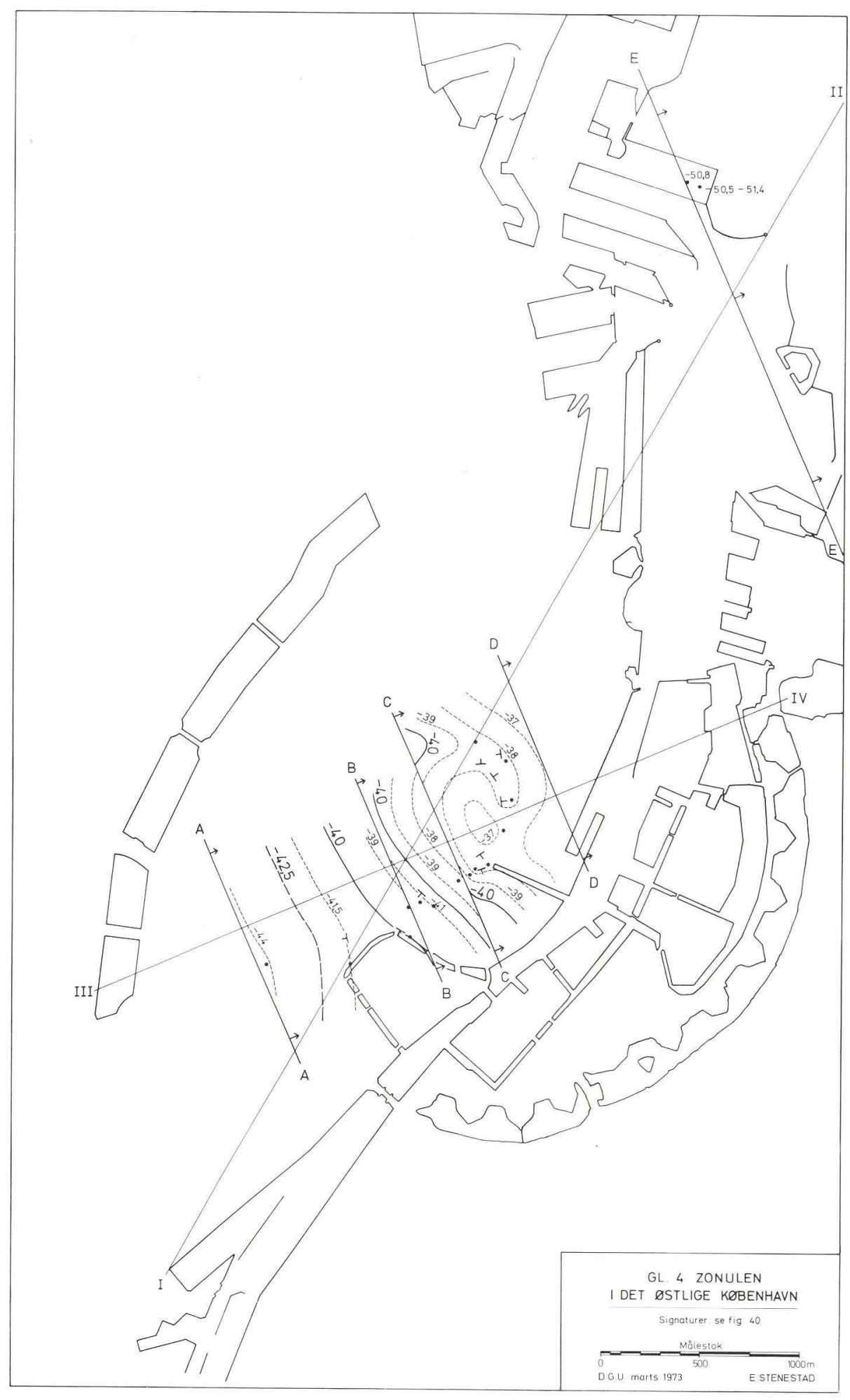


København ligger på en struktur, der bedst kan beskrives som en svag fold, og forfatteren vil gerne her fremsætte den tanke, at der muligvis kan være en sammenhæng mellem denne struktur og Saltholm-Limhamn strukturen. Man kan forestille sig, at de nævnte strukturer er nogle svage folder med akser, der stryger omtrent sydøst-nordvest, og som dykker fra Limhamn mod København, med kulminationer under Limhamn-Saltholm og under København. De mange boringer på og ved Saltholm, at hvilke de seneste blev udført i vinteren 1974-75, har vist, at Saltholms struktur, lige som den københavnske struktur, bedst kan beskrives som en flad banke eller fold, hvis akse stryger omtrent vestnordvest-østsydøst og dykker svagt i vest-nordvestlig retning. Kridtoverfladen hælder generelt så lidt som 1:200, men østligst på øen er relieffet ifølge Saltholmboring 11-14 muligvis lidt stærkere, med hældninger af størrelsesordenen 1:70. Lagene ligger således meget fladt, hvad der i forbindelse med selv små uregelmæssigheder i de geologiske fladers beliggenhed og lidt varierende erosionsdybder vil kunne medføre en meget uregelmæssig fordeling af danienbjergarterne i overfladen. Dette er netop, hvad man finder på Saltholm. Det er kun på øens vestligste del, at alle boringer har nået København Kalken. På de øvrige dele af øen finder man kalksten, tilhørende bryozokalkenheden, eventuelt overlejret af en lille erosionsrest af København Kalk. En konsekvens af Saltholms struktur (fold eller banke) er, at man kun kan forvente at finde København Kalk nordvest, vest og syd for $\emptyset$ en, medens man nordøst, øst og sydøst for øen må vente at finde bryozokalkenhedens bjergarter, en bjergartsfordeling, som er bekræftet ved de senere års boringer i Øresund omkring Saltholm.

Af det anførte fremgår, at den københavnske kridt-tertiær lagserie flere gange har været genstand for laramiske deformationer. De på Saltholm i maastrichtien optrædende glideflader med harniske (bor.11), breccieringen af maastrichtienlagenes $\varnothing v$ re hardground (bor. 11, 13, 14), de to sedimentationsafbrydelser (bor. 12) og de markante slump beds nederst i bryozokalkenheden (bor. 12, 14), samt konglomeratet (i kalkbruddene) og glidefladerne (bor. 12) nederst i København Kalken er lokale fænomener, som formentlig

Fig. 42: Strukturkort: Turborotalia sp. 4 subzonen (»Gl. 4«) som defineret af Bang(In: Bahnson, Bang og Stenestad 1970). Efter Stenestad (1973 a).

Fig. 42: Structural map. The Turborotalia sp. 4 subzone, sensu Bang (In: Bahnson, Bang and Stenestad, 1970). Map according to Stenestad (1973 a).

Fig. 43: Strukturkort: Grænsefladen mellem bryozokalkenheden (BZK) og København Kalken (KSK). Efter Stenestad (1973 a).

Fig. 43: Structural map: The border level between the Bryozoan Limestone unit (BZK) and the superjacent Kobenhavn Limestone (KSK). According to Stenestad (1973 a). 


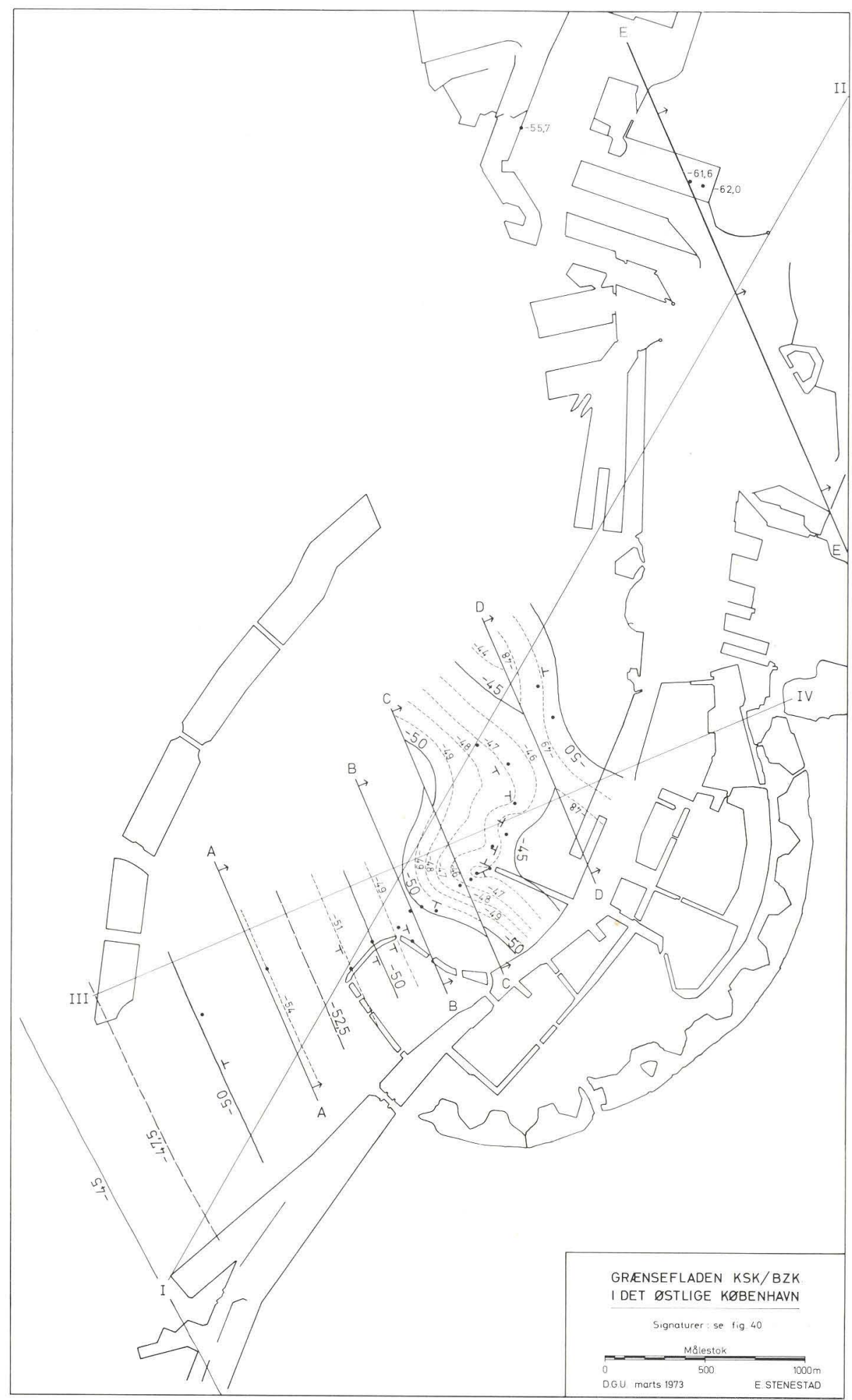




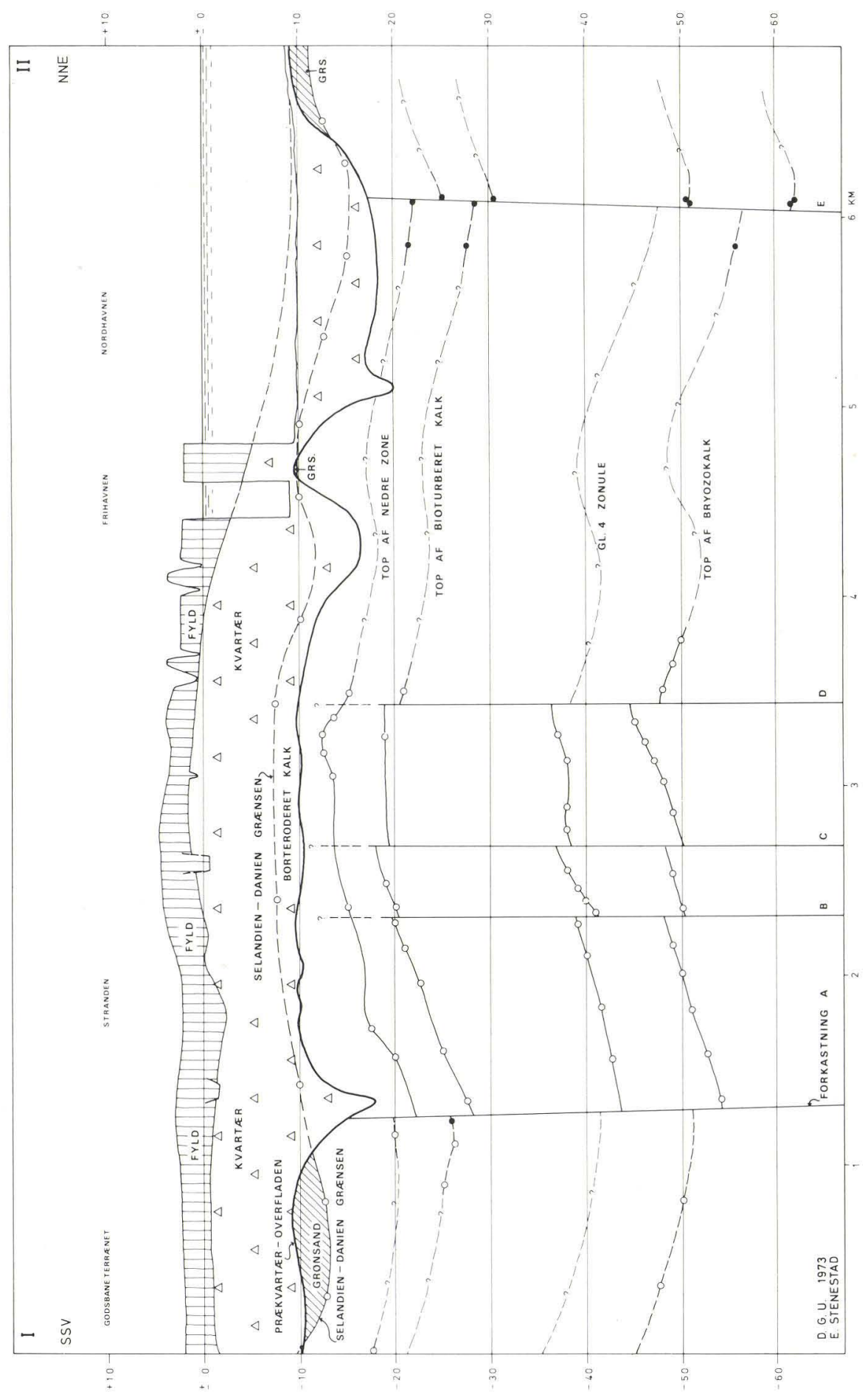


skyldes bevægelser i Saltholm-Limhamn strukturen i øvre maastrichtien, på grænsen maastrichtien-danien og i den yngre del af danien, svarende til den nederste del af København Kalken. Af større regional udbredelse er den svage foldning, der kan spores i hele Øresundsregionen, og som i Københavnsområdet kan dateres til et tidspunkt i den øvre del af danien, svarende til den nederste del af København Kalken. Forkastningerne (A-E) i København viser opefter aftagende springhøjder og har antagelig været aktive flere gange i danien. Den udbredte optræden af omlejret maastrichtien-materiale $i$ den $\emptyset$ verste del af København Kalken tyder på tektonisk aktivitet i Øresundsregionen i den sidste del af danien. Flintbreccien (fig. 22) øverst i København Kalken i Nicolaj kvarteret i København tyder ligeledes på tektonisk aktivitet ved slutningen af danien. Forkastningerne A og E i København (Rådhuspladsen og Svanemøllen) gennemskærer øjensynligt hele danienlagserien og er således yngre end danien.

Fig. 44: Længdesnit I-II fra Gasværkshavnen til Nordhavnen. Beliggenheden er vist på fig. 43. Snittet er konstrueret på grundlag af strukturkortene, fig. 39-43. A ben cirkel: Punkt fra kurveplan; udfyldt cirkel: Punkt fra projektion. Grs. = grønsand. L. Grs. = Lellinge Grønsand. Bemærk: Højdemålestokken er 50 gange længdemålestokken. Efter Stenestad (1973 a).

Fig. 44: Vertical section I-II through Copenhagen City as indicated in fig. 43. Section constructed on the basis of structural maps figs. 39-43. Open circles: Points according to the structural maps. Filled circles: Projected points from nearby boreholes. Grs. = greensand. L. Grs. = Lellinge Greensand. Note that the heights are 50 times exaggerated. According to Stenestad (1973a). 


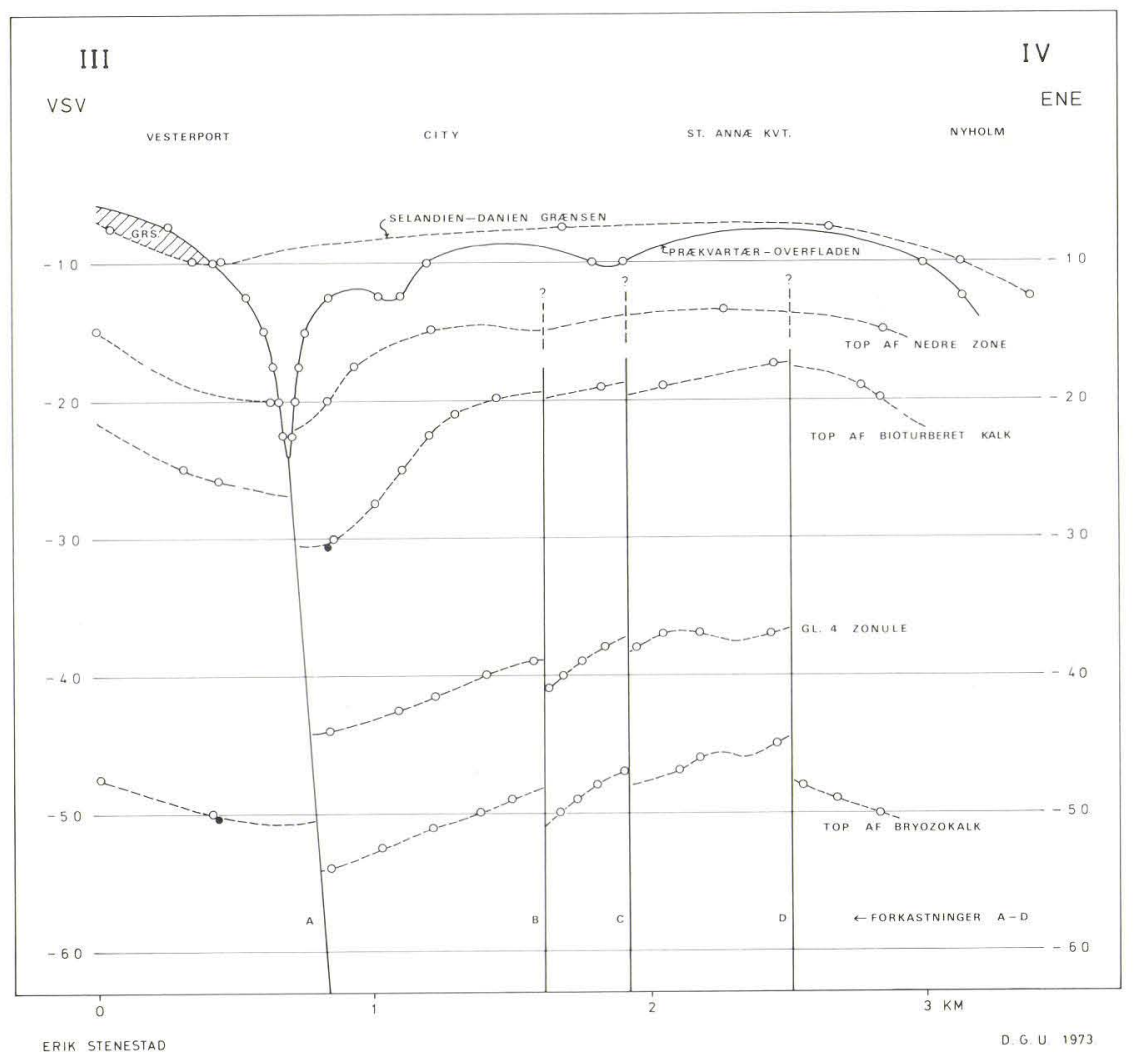

Fig. 45: Længdesnit III-IV fra Vesterport til Nyholm. Beliggenheden er vist på fig. 43. Snittet er konstrueret som fig. 44, men er lagt vinkelret på den formodede foldeakse. Grs. = grønsand. L. Grs. = Lellinge Grønsand. Efter Stenestad (1973 a).

Fig. 45: Vertical section III-IV through Copenhagen City as indicated in fig. 43. Section constructed in the same way as fig. 44 , but laid at right angles to the assumed direction of the fold axis. Grs. = greensand. L. Grs. = Lellinge Greensand. According to Stenestad $(1973$ a). 


\section{Områdebeskrivelser}

\section{Sydhavnen (Sydhavnstunnelen)}

De geologiske forhold i Sydhavnen er omtalt af blandt andre Rosenkrantz (1920a, 1923, 1924a, 1925, 1934). Profilerne er ikke mere tilgængelige, men ledningstunnelen under havnen var i en periode i efteråret 1970 tømt for vand, og forfatteren havde lejlighed til at opmåle den.

Tunnelen er udført i 1921 (fig. 46). Dens bund ligger i kote $\div 19,1 \mathrm{~m}$ ved Enghave Brygge og i kote $\div 18,6 \mathrm{~m}$ ved Islands Brygge. Den er ved lodrette skakte forbundet med gadeniveau. Situationsplanen, fig. 47, viser beliggen-

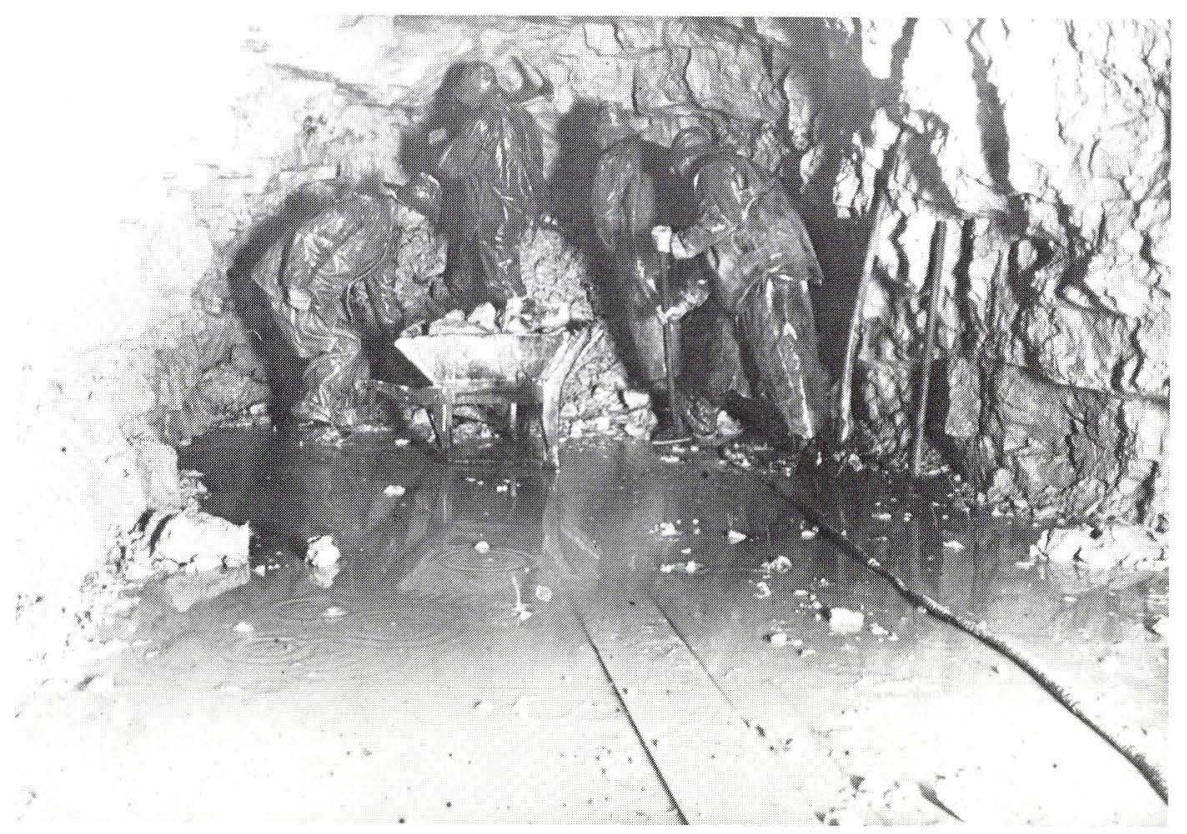

Fig. 46. Sydhavnstunnelen. Servicetunnel under Københavns Havn fra Enghave Brygge til Islands Brygge (se fig. 47). Arbejdere i færd med at hugge sig frem gennem København Kalken. Efteråret 1921. Bemærk kalkens tydelige bænkning. Venligst udlånt af Alfred Rosenkrantz. Fig. 46: The Sydhavnstunnel. Service tunnel in Kobenhavn Limestone under the south harbour of Copenhagen (location shown at fig. 47). Notice the jointing of the limestone. Courtesy of Alfred Rosenkrantz. 


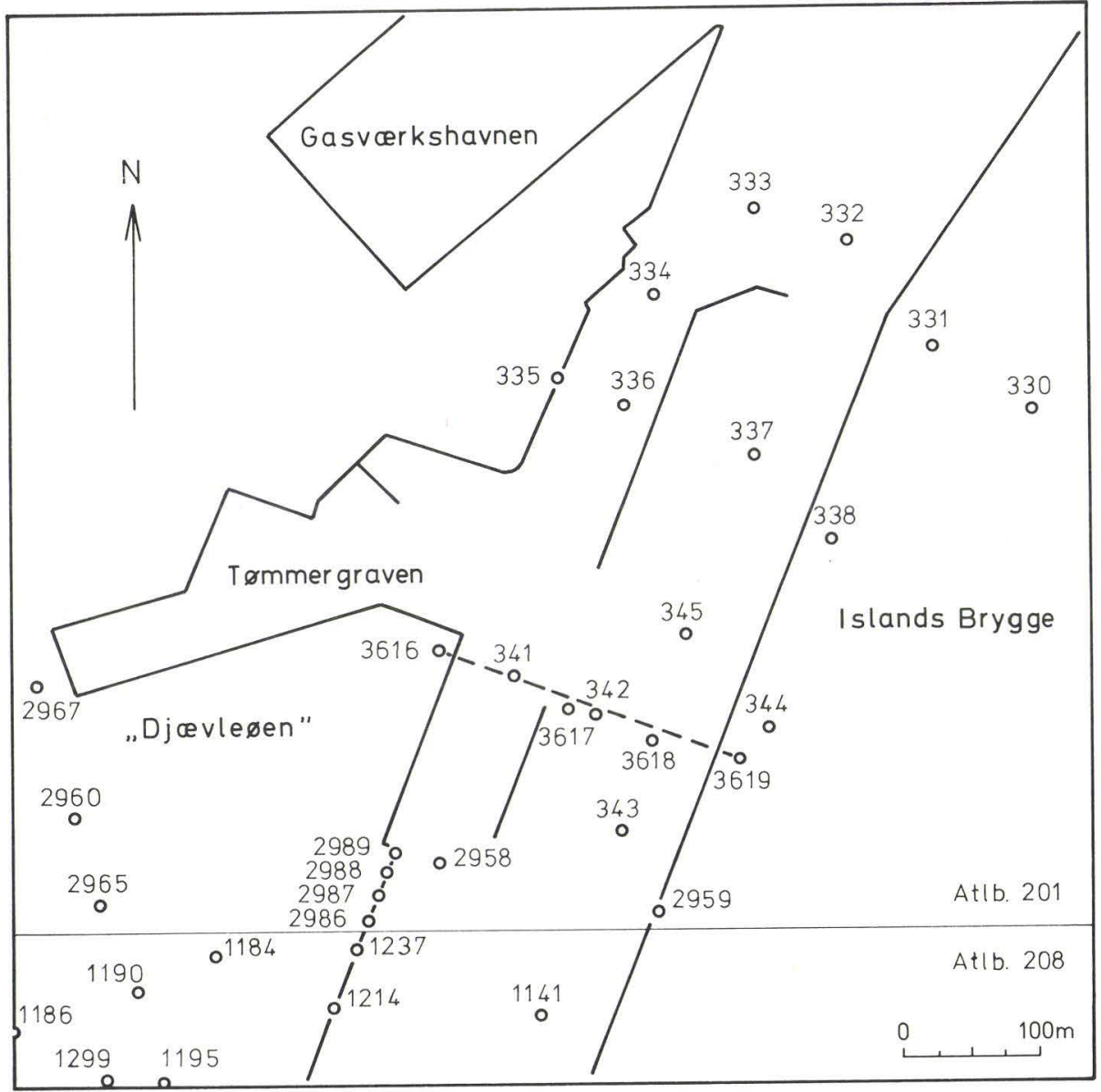

Fig. 47: Situationsplan visende beliggenheden af Sydhavnstunnelen (stiplet) og omliggende prækvartærboringer. Efter Stenestad (1971 a).

Fig. 47: Map showing location of the Sydhavnstunnel (dashed line) and nearby boreholes penetrating to the Pre-Pleistocene deposits. According to Stenestad (1971 a).

heden af tunnelen og de boringer, der er udført i dens nærhed. Opmålingen blev udført på den måde, at tunnelvæggen blev afrenset og opmålt 12 steder, der er betegnet M 1 - M 12 på fig. 48. Vægfladerne mellem de opmålte profiler blev inspiceret, og de enkelte kalk- og flintbænke fulgt fra profil til profil. Ved optegningen af længdeprofilet, fig. 48, tegnedes tunnelgulvet som en ret linie mellem koterne $\mathrm{i}$ endepunkterne. På en tidligere nivelleret delstrækning afviger tunnelgulvet en smule fra denne linie, men da der ikke foreligger noget komplet nivellement, er den halvskematiske afbildningsform foretrukket. Beskrivelserne af de opmålte profiler findes i Stenestad (1971a) og er ikke 
taget med i den foreliggende publikation. På længdesnittet er indtegnet boreprofiler fra kalkboringer ved tunnelen. Beskrivelserne findes i DG.U's borearkiv. Boringerne er desuden opført i kotelisten, tabel 1.

Lagstilling. Tunnelens vægge var dækket af et flere millimeter tykt lag af rødbrune mineraludskillelser, som måtte fjernes ved hugning, før kalken kunne studeres. I det væsentlige blev kun de opmålte profiler afrenset. Renhugningen tillader ikke de finere detaljer at træde klart frem, og en videregående præparation blev ikke gennemfort. Det var derfor ikke muligt at afgøre, om en primær lagdeling eventuelt var tilstede. Kalken ses derimod at være tydeligt bænket, og gennemgående bænke af kalk og flint findes på hele tunnelstrækningen. Bænkene er svagt bølgende og hælder ganske svagt mod Enghave Brygge, hvad der er i overensstemmelse med tidligere iagttagelser i området (Rosenkrantz 1924a, m.f1.). Den nøjagtige hældning og strygning har endnu ikke kunnet fastslås trods de mange store udgravninger (bl.a. Sydhavnen I og II) og det store antal boringer i området. De meget små hældninger og fladernes bølgende forløb vanskeliggør direkte målinger i profiler. En beregning af den generelle lagstilling ved hjælp af boringer ville være gunstigere, men man savner en anvendelig referensflade i denne del af formationen.

Flint. Flinten er af den sædvanlige grå, tætte, kalkholdige type. Den optræder dels som spredte knolde, dels som sammenhængende lag, der ikke er helt regelmæssige. Specielt synes de i den østlige del af tunnelen at variere meget $\mathrm{i}$ tykkelse. Der er i selve tunnelen iagttaget 4 markante flintlag. De er i de lodrette skakte indmålt til gadeniveau.

Kalkens karakter og hardningstilstand. Tunnelen ligger i den øvre del af København Kalken i kalksandskalk, som stedvis er tydeligt bioturberet. Den lithologiske referensflade mellem den bioturberede København Kalk og den overliggende, regelmæssigt lejrede del af København Kalken har dog ikke kunnet påvises i tunnelen. Kalken er overvejende svagt hærdnet eller uhærdnet, men med hærdnede og stærkt hærdnede partier eller kalkbænke. Enkelte steder er kalken let leret, men egentlige lerlag er ikke bemærket.

Sprakker og vandtilstrømning. Flere steder i tunnelen, især ved Islands Brygge, ses en del kraftige sprækker, som retlinet skærer loft og vægge. Tunnelens tilstand gav indtryk af, at kalken generelt er stærkt sprækket på dette sted. Flere steder på strækningen er tunnelloftet faldet ned, og nogle steder er der foretaget understøtning af loftet (fig. 49) eller udforing med beton. Vandtilstrømningen sker hovedsagelig fra sprækker i forbindelse med bænkningen samt fra nogle få, store, tilfældigt orienterede sprækker i loft og vægge. Tilstrømningen er forholdsvis beskeden, ca. $70-80 \mathrm{~m}^{3} / \mathrm{t}$, tunnelens dimensioner taget i betragtning. Ifølge Geoteknisk Institut (1971b) er tunnelen $237 \mathrm{~m}$ lang, 2,0 m høj og 2,0-2,7 m bred. Volumen er ca. $1200 \mathrm{~m}^{3}$. Dansk Kedelforenings luftforureningslaboratorium har foretaget analyser af luftens 


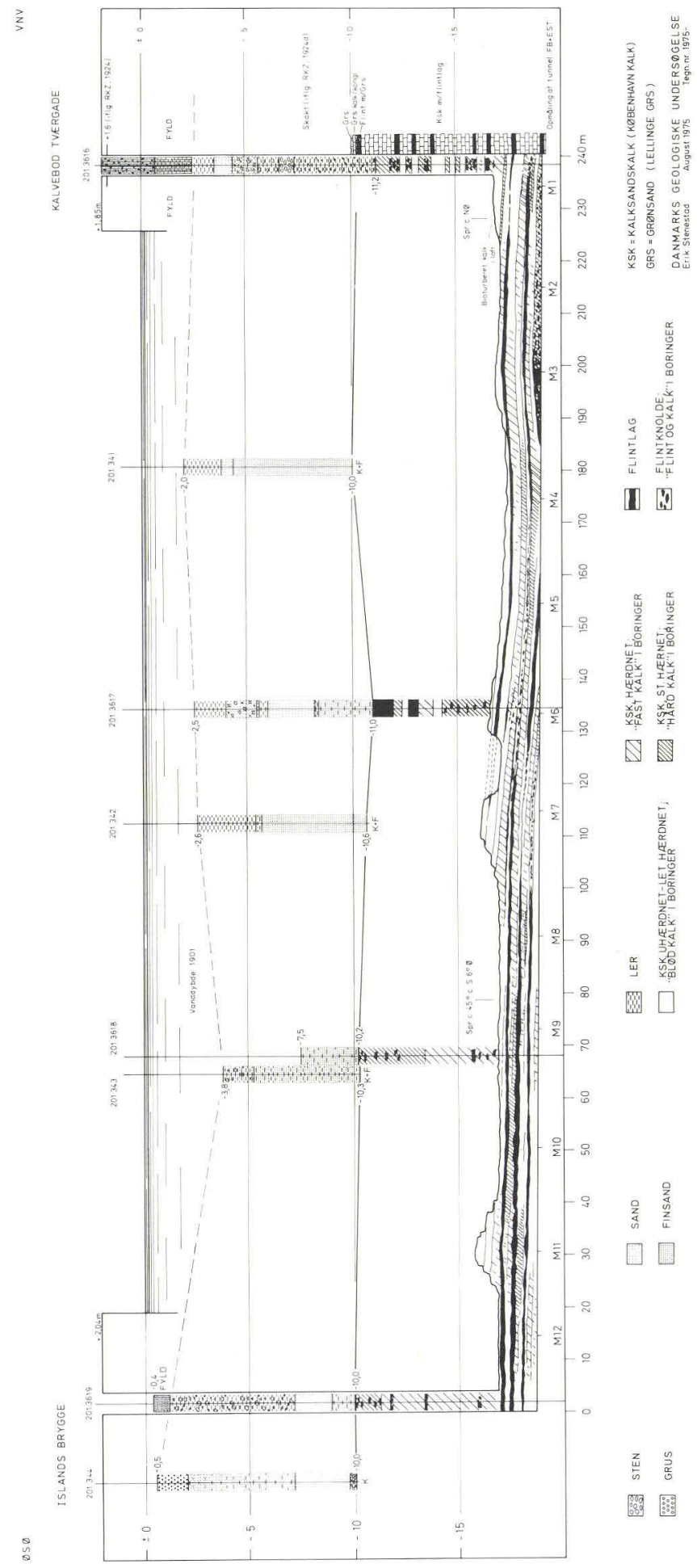


sammensætning i tunnelen (den er normalt vandfyldt), og har på det dårligst udluftede sted fundet forholdsvis høje svovlbrintekoncentrationer (15 ppm) og et lille iltindhold (13 vol. \%). DGU's laboratorium har udført vandanalyser af det indstrømmende vand, 1., 4. og 8. døgn efter tømningen af tunnelen. Analysen ændrede sig ikke væsentligt i løbet af denne periode. Saltkoncentrationerne var 1,4 à $1,7 \%$.

\section{Området mellem Sydhavnen og Søerne}

Dette område er beskrevet i en lang række afhandlinger af blandt andre Johnstrup (1876), von Koenen (1885), Rørdam (1897, 1899), Grønvall (1899), Rosenkrantz (1920a, 1920b, 1924a, 1925, 1930), Harder (1922), Gry (1935) og Milthers (1935).

Området, der er referenceområde for Lellinge Grønsand, er godt kendt fra boringer og udgravninger. Boringerne TUBA 1-15 (fig. 11-12) dækker en stor del af området og knytter forbindelsen mellem Lellinge Grønsandets referencelokalitet og Den indre by. Blokdiagrammet, fig. 32, giver et overblik over fordelingen af jord- og bjergarter. Forholdene omkring det tidligere Vestre Gasværk er illustreret fig. 50, hvor Rosenkrantz's profil fra 1930 er sammenstillet med nærliggende citybaneboringer.

København Kalk. I området mellem Sydhavnen og Søerne ligger boringen TUBA 13 (DGU nr. 201.3080), der er valgt som typelokalitet for København Kalk. I dette område, hvor boringerne ellers ikke nåede så langt ned i kalken, var grænsen mellem København Kalk og Lellinge Grønsand (fig. 39) den eneste lithologiske referensflade, som var til rådighed for en vurdering af lagstillingen. Inger Bangs foraminiferzonering af den øvre del af København Kalken kom derfor til god nytte. Det kan på grundlag af undersøgelsen ikke helt udelukkes, at der i området kan findes forkastninger med indtil et par meters springhøjde, men sandsynligheden herfor er ikke stor. En vis mistanke kan eventuelt rettes mod området ved TUBA bor. 5 .

København Kalkens overflade. Kalkoverfladens beliggenhed fremgår af kortet, fig. 51. I dette område, hvor kalken er dækket af Lellinge Grønsand, er

Fig. 48: Sydhavnstunnelen. Længdesnit, sammenstillet på grundlag af en opmåling af tunnelens SSV-væg og boringer ved tunnellinien. Profil ved skakten i Kalvebod Tværgade ifølge Rosenkrantz (1924 a). Boringer ifølge Danmarks Geologiske Undersøgelses borearkiv. Opmåling af tunnelen: Finn Bertelsen og Erik Stenestad. Efter Stenestad (1971 a).

Fig. 48: The Sydhavnstunnel. Vertical section compiled on the basis of data from the Geological Survey (DGU) and surveys by Rosenkrantz (1924 a), Finn Bertelsen and Erik Stenestad (september 1970). According to Stenestad (1971 a). 


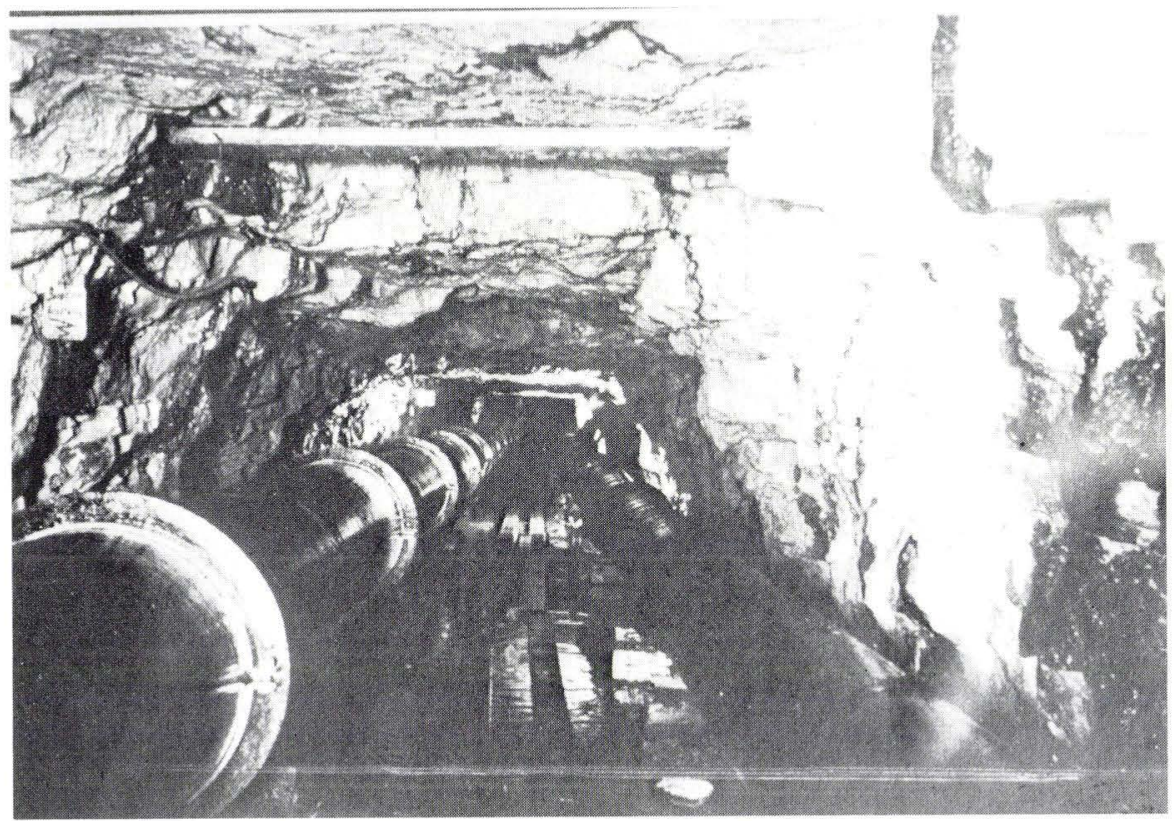

Fig. 49: Sydhavnstunnelen. Januar 1922. Hårde kalkbænke danner loft, som dog på grund af indstyrtninger er noget ujævnt. Venligst udlănt af Alfred Rosenkrantz.

Fig. 49: The Sydhavnstunnel in January, 1922. The ceiling is formed by benches of indurated limestone. Downfall of parts of the roof make the ceiling uneven. Courtesy of Alfred Rosenkrantz.

den gamle, ikke-isskurede kalkoverflade bevaret, og ved at sammenholde kortet over kalkoverfladen med kortet over prækvartæroverfladen (fig. 35), kan man se, at Lellinge Grønsandet udjævner det i forvejen svage relief yderligere. I boringerne TUBA 8-10 og 1-4 ligger kalkens erosionsoverflade let skrånende og svagt bølgende mellem kote $\div 11 \mathrm{og} \div 13 \mathrm{~m}$, og her er det selandienhavets erosion alene, der har givet kalkoverfladen dens relief. I boring TUBA 5-7 stiger kalkoverfladen til kote ca. $\div 8,5 \mathrm{~m}$, for derpå at ligge jævnt bølgende omkring kote $\div 11-\div 12 \mathrm{~m}$ i boringerne TUBA 11-15. Boringerne $\mathrm{i}$ området vest for Hovedbanegården giver ikke anledning til særlige bemærkninger, hvad København Kalken angår. Det var i forvejen kendt, at kalkoverfladen stiger i vestlig retning og ligger højt i området ved Gl.Kongevej, i boring TUBA 403 således i kote $\div 3,8 \mathrm{~m}$.

Enkelte steder er der set mørkebrune siltstriber og sprækkeudfyldninger i den $\emptyset$ verste del af kalken, i boring TUBA 11 således i de øverste ca. $2,5 \mathrm{~m}$ under kalkoverfladen. En prøve af dette sprækkefyldningsmateriale indeholdt danien-foraminiferer og tertiært pollen samt en lille del sikre kvartære 


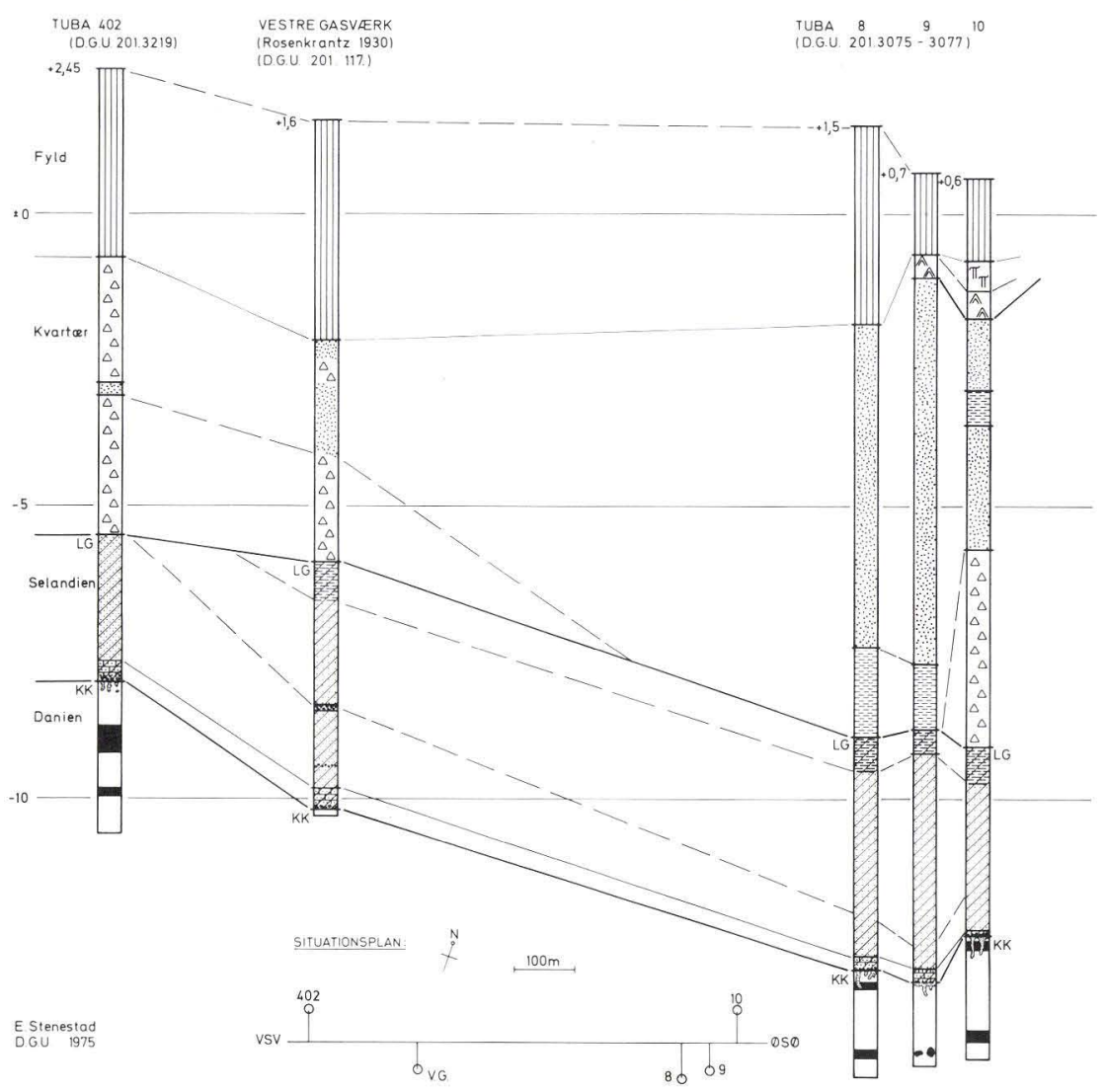

Fig. 50: Længdesnit gennem område ved Vestre Gasværk. Signaturer, se fig. 5.

Fig. 50: Vertical section at the reference profile of the Lellinge Greensand (Vestre Gasvark). Legend, see fig. 5.

pollen. Intet tyder på, at den overliggende kalk skulle være omlejret, og man må derfor antage, at de pågældende sprækker står i forbindelse med kvartærlagene, muligvis gennem en lille doline (»skorsten«), d.v.s. en tragteller rørformet fordybning i kalkoverfladen, frembragt af nedsivende, aggressivt vand.

Lellinge Grønsand. Boringen TUBA 403 ved Gl. Kongevej ligger uden for det område, hvor man venter at finde faststående selandien. At der imidlertid har været Lellinge Grønsand tilstede fremgår af de grønsandsfyldte sprækker $\mathrm{i}$ toppen af kalken. I boringerne TUBA 402 og 408-410 nær referencelokaliteten Vestre Gasværk finder man de fleste af de kendte Lellinge Grønsand bjergarter: glaukonitholdig konglomerat, kalk, sand og ler (grønsandskalk, grønsand og grønsandsler). I de nævnte boringer hviler bundkonglomeratet 


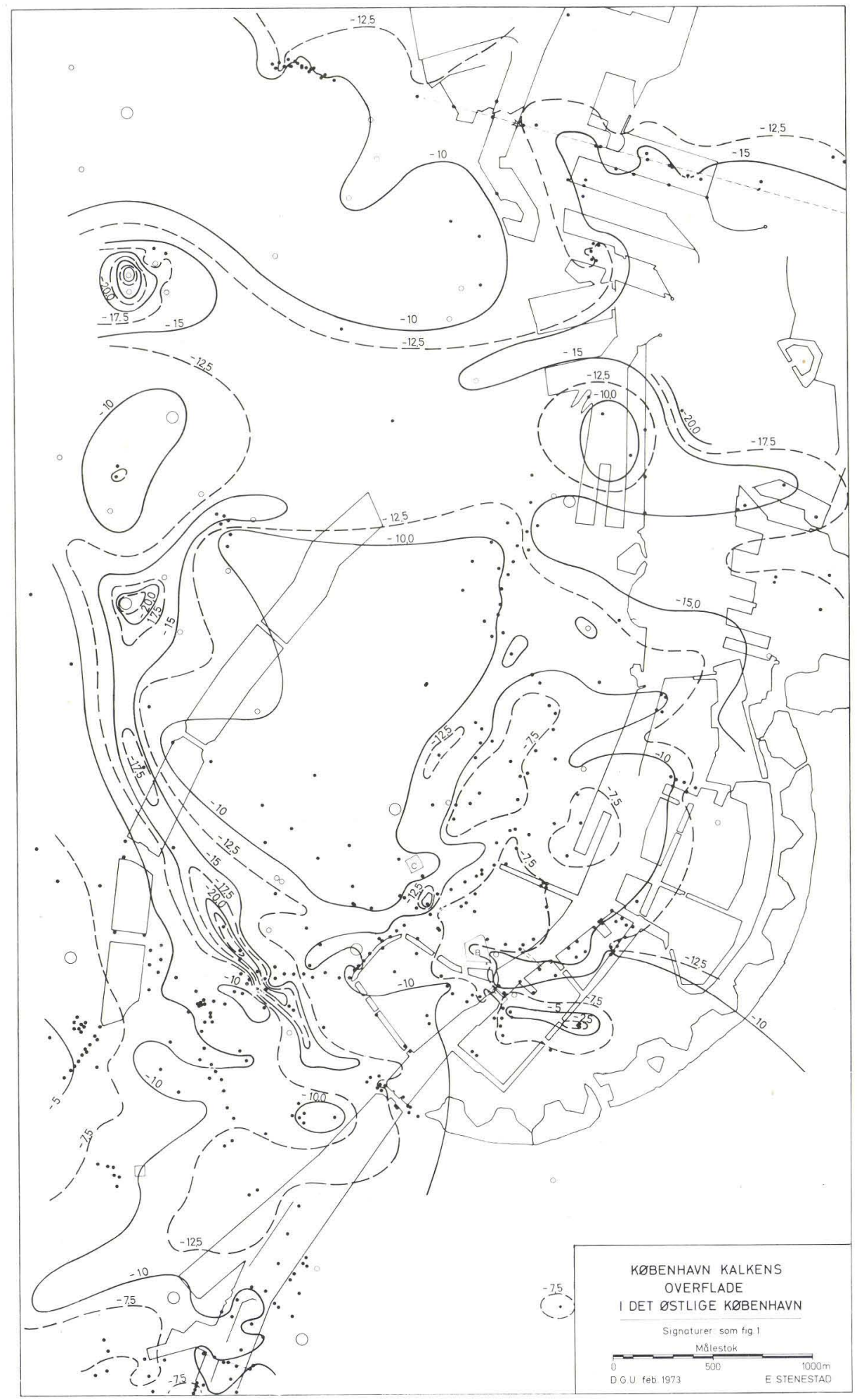


på København Kalkens stærkt hærdnede og eroderede overflade, som også her er gennemsat af sprækker fyldt af Lellinge Grønsand (fig. 50).

Lellinge Grønsandets lagtykkelse varierer en del, især som følge af glacial erosion. En bred, flad lavning strækker sig fra Glyptoteket ind langs Tietgensgade til Reventlowsgade, hvor den ses i tværsnit i boringerne TUBA 2-6. I boringerne TUBA 2-4 er der praktisk taget ingen Lellinge Grønsandaflejringer bevaret, og i boring TUBA 5 og 6 mangler de helt.

De fleste boringer med Lellinge Grønsand har grønsandskalk og evt. bundkonglomerat overlejret af grønsand, men i enkelte boringer, f.eks. TUBA 7 og 14, findes grønsand direkte over København Kalken. Grønsandskalkens fravær kan teoretisk skyldes tektonik, som har skubbet den nederste del af Lellinge Grønsandet ud, men det forekommer mere sandsynligt, at selandienhavet var forholdsvis lavvandet, og at sedimentationsforholdene vekslede en del inden for korte afstande. Nogle steder blev der eroderet i danienkalken, andre steder dannede danienkalklagene bund, som hverken blev eroderet eller sedimentdækket, og atter andre steder blev der - afhængigt af energiforholdene - aflejret groft eller fint kalkmateriale (fra danien) eller glaukonitisk sand.

Kvartarlagene. Det er generelt for området, at moræneleret er ret kalkholdigt og stedvis rigt på flint og kalksten. Det indeholder spredte lag af morænesand og -grus. Smeltevandssandet, der indeholder spredte grus-, silt- og lerlag, er overvejende af glacial alder. Postglaciale aflejringer forekommer kun i ringe mængde, skønt området har ligget under stenalderhavets øvre grænse (i kote ca. 3,5 m).

I det meste af området findes en ca. $5 \mathrm{~m}$ tyk morænebænk, som hviler på den prækvartære undergrund (fig. 32). Ved Tietgens Bro (TUBA 1 og 2), er morænen hårdt konsolideret og stærkt grus- og stenholdig. Den er overlejret af morænesand og fyld. Syd herfor overlejres morænen af grus-, sand- og siltlag, som er sammenhørende med den finkornede, nederst let siltholdige sandserie, der ved Ingerslevsgade (TUBA 8 og 9) overlejrer prækvartærlagene. Denne sandserie kunne efter sin beliggenhed være postglacial, men der findes intet i prøverne, som støtter dette, hvorfor den her er opfattet som en smeltevandsdannelse. Øverst i profilerne findes en af de sjældne forekomster af kalkholdigt, postglacialt, marint ler.

Fra Tietgens Bro til Banegraven ved Frihedsstøtten passeres den ovennævnte sidedal til Rådhuspladsdalen. Den rummer næsten udelukkende

Fig. 51: København Kalkens overflade. Denne flade danner i nogle områder underlag for Lellinge Grønsandet, i andre for de kvartære dannelser.

Fig. 51: Present surface of the Kobenhavn Limestone, which in some areas is covered by the Lellinge Greensand, in other areas by Quaternary deposits. 
smeltevandssedimenter. Lagenes glaciale alder fremgår af det delvise morænedække (TUBA 4-7).

Boringerne ved Banegraven (fig. 32) danner overgang til boringerne i Vesterbrogade, idet den nedre morænebænk tiltager i mægtighed, medens den overliggende finsands- og siltrige sandaflejring tynder ud. Mellem Frihedsstøtten og Akseltorv finder man en opbygning af den glaciale serie, som traditionelt anses for typisk for København, nemlig to morænelersbænke med en mellemliggende serie af smeltevandsdannelser.

\section{Den indre by}

I dette afsnit omtales strækningen Akseltorv - Rådhuspladsen (fig. 12) Vandkunsten (fig. 13) - Nybrogade (fig. 14) - Gl.Strand - Højbro Plads Nicolaj Plads (fig. 15) - Bremerholm - Kgs. Nytorv (fig. 16). Desuden omtales tunnelerne under havnen mellem Havnegade og Christianshavn (fig. 52-55).

Bryozokalkenheden. Bryozokalkenheden er overalt i området stærkt præget af slamkalk, og bryozokalken er fattig på bryozofragmenter. Den øverste del er hærdnet og eroderet (hardground) og grænsen til København Kalken har uden vanskelighed kunnet fastlægges i boringerne (fig. 9). Bryozokalkenhedens overgrænse falder jævnt fra Kgs. Nytorv (kote $\div 46 \mathrm{~m}$ ) til Rådhuspladsen (kote $\div 54 \mathrm{~m}$ ). På strækningen Kgs. Nytorv-Nybrogade, hvor der er tætliggende observationer af fladens beliggenhed, afviger den mindre end 1 $\mathrm{m}$ fra den rette linie mellem yderpunkterne. Der er et tilsvarende fald i den overliggende lagseries referensflader. Boringerne ved Nicolaj Plads - Bremerholm danner dog en undtagelse, idet der her er en 2-3 m dyb lavning i bryozokalkens overflade. Der findes en tilsvarende lavning i København Kalkens og den bioturberede København Kalks overflade. Som tidligere anført, skyldes dette formodentlig tilstedeværelsen af nogle små forkastninger med få meters springhøjde (B og C på fig. 43 m.fl.).

København Kalken. København Kalken er фverst regelmæssigt lejret, finkornet og svagt lerholdig, derunder uregelmæssigt lejret som følge af bioturbation og nederst atter regelmæssigt lejret og ret leret. Som det var tilfældet i boring TUBA 13 ved Hovedbanegården finder man enkelte steder en tæt, hvid, marmorlignende kalk, og der indgår desuden lag eller partier af grovere kalksand (kalkarenit), som vidner om forbigående ændringer i sedimentationsforholdene. I denne forbindelse kan det nævnes, at de øverste 10 $m$ af København Kalken i en boring på Amager Fælled (TUBA 131) var mindre finkornet og mere præget af skalrester end kalken i City. Ved faunaundersøgelsen nåede Bang (In: Bahnson et al. 1972) til den opfattelse, at det geologiske miljø næppe er helt identisk med det, som har rådet i City. 
Lellinge Grønsand. Efter at Københavnsområdet i slutningen af danienperioden var hævet og sedimentationen ophørt, blev den øvre del af København Kalken hærdnet og eroderet. Da selandienhavet transgredierede området, blev også Den indre by overskyllet. Selandienhavets aflejringer har dækket hele Den indre by, hvad der fremgår af de spredt forekommende rester af Lellinge Grønsandets bundkonglomerat og af de talrige grønsandsfyldte sprækker i toppen af København Kalken. Lellinge Grønsandets aflejringer findes især i de områder, hvor kalkoverfladen ligger højt, hvorimod de synes at mangle i kvarteret mellem Stranden og Rådhuspladsen, hvor kalken ligger dybere. Det er nærliggende at forestille sig, at erosionen her har været mere dybtgående, hvad strukturforholdene iøvrigt også tyder på.

Prakvartceroverfladen. Den indre by ligger på en højderyg af København Kalk. Fra Akseltorv mod Rådhuspladsen stiger kalkoverfladen til omkring kote $\div 9 \mathrm{~m}$, og stigningen fortsætter i retning af Slotsholmen. Højderyggens højeste del findes omkring Knippelsbro. Ved Christiansborg Slotsplads og Holmens Kirke træffer man kalkoverfladen omkring kote $\div 5-\div 7 \mathrm{~m}$, og i kvarteret mellem Knippelsbro og Vor Frelsers Kirke har ældre boringer truffet kalk få meter under havniveau. Fra dette højdeområde er der et generelt fald i retning af Kgs. Nytorv.

Ser man på prækvartæroverfladekortet, fig. 35, er det især de forholdsvis kraftigt markerede dale og lavninger i kalvoverfladen, som tiltrækker sig opmærksomheden. I den sydvestlige del af kalkhøjderyggen finder man en smal og dyb dal i kalkoverfladen, Rådhuspladsdalen, der er nordvest-sydøst orienteret, og stort set følger H.C. Andersens Bd.. Den er en del af et dalsystem, som fortsætter via Ørstedsparken og Dr. Louises Bro til De Gamles By og Rigshospitalet og derfra drejer mod øst til Frihavnen. Dalsystemets dybeste dele findes ved Rådhuset (kote ca. $\div 22 \mathrm{~m}$ ) og ved De Gamles By (kote ca. $\div 25 \mathrm{~m}$ ) og ikke ved en af dalens mundinger. Der er ikke påvist grønsandsaflejringer i dalen, som udfyldes af grove smeltevandsdannelser. På grund af lagseriens opbygning og det ujævne bundrelief opfattes den som en subglacial dal. Den er antagelig på en del af strækningen opstået i forbindelse med en forkastningszone i kalken, forkastning A (fig. 40). Rådhuspladsdalens sedimentserie overlejres af den nedre, grus- og stenrige morænelersbænk, som er den ældste morænelersbænk i cityområdet, og dalen er således dannet før den tidligere omtalte, relativt unge smeltevandsdal fra Glyptoteket til Stampesgade, hvis sandserie er sammenhørende med de smeltevandsdannelser, som adskiller de to morænebænke i området.

Som et led i det beskrevne dalsystem findes der en smal sidedal til Rådhuspladsdalen, som, noget slyngende, løber parallelt med havnen fra Rådhuspladsen til Grønningen. Dalen har et dybdepunkt ved Nicolaj Plads. De ovenfor omtalte forkastninger, B og C findes netop i dette område, og dalens udform- 
ning kan muligvis være delvis betinget af prækvartærlagenes strukturforhold. Der synes således at være en særlig høj frekvens af stærkt sprækket og knust kalk i Gl. Strand - Nicolaj Plads-området, hvor der også er fundet skurestriber på kalkoverfladen, og hvorfra flintbreccien, fig. 22, stammer.

Med hensyn til Rådhuspladsdalens og dens sidedales forløb viser det sig, at ældre oplysninger støtter den her fremsatte opfattelse. Dalsystemets aflejringer er stærkt prægede af sand, medens området iøvrigt er et morænelersområde. Ved en kartering, som når ned under den almindelige fyldtykkelse på 1-3 m, kan man således vente at få et kort, der viser et morænelersområde med sandfyldte dalsystemer og med særligt fyldprægede områder, f.eks. voldgrave, havneområder, etc.. Et sådant kort eksisterer. Det er vist som plan VI i Ambt, Johnstrup og Steenbuch (1888), og det supplerer på udmærket måde de her fremlagte oplysninger.

Kvartarlagene. De to morænelersbænke, som findes mellem Frihedsstøtten og Akseltorv, kan følges helt til Lavendelstræde. Derimod mangler den $\emptyset$ vre morænelersbænk i det gamle havneområde fra Frederiksholms Kanal til Højbro Plads. I sammenfatning kan man om de glaciale lag sige, at de er stærkt vekslende og flere steder stærkt prægede af kalk og flint fra de prækvartære kalkaflejringer.

I Rådhuspladsdalen under H.C. Andersens Bd. findes en indtil $14 \mathrm{~m}$ mægtig serie af groft og stenrigt smeltevandsgrus, der overlejres af sten- og grusrigt moræneler eller af morænegrus. Midt i dalen findes rester af en gytjepræget mose- eller havaflejring af ringe mægtighed, men området ved Rådhuspladsen er især karakteriseret af betydelige fyldlag af op til 9 meters mægtighed. De hidrører fra større og mindre fæstningsværker, som siden middelalderen har præget området mellem Vestervoldgade og Tivoli.

Over mod Vestervoldgade bliver de grove dalsedimenter erstattet af relativt groft smeltevandssand, der overlejres af moræneler med striber af smeltevandsgrus, -sand og -ler. Denne sidste formation kan måske tolkes som ablationssedimenter med flow till (Marcussen 1973). Videre på strækningen mellem Rådhuspladsen og Frederiksholms Kanal findes en ca. 6 m mægtig morænelersbænk med næsten horisontal underside omkring kote $\div 9 \mathrm{~m}$. Moræneaflejringerne er på denne strækning gennemgående meget sandede og stenede, og der indgår lag af lagdelt sand og tynde lag af ret fedt ler. Under morænelersbænken ligger et sand- og gruslag, som aftager i mægtighed bort fra Rådhuspladsen. Det er formentlig stratigrafisk sammenhørende med Rådhuspladsdalens smeltevandsserie. Over morænen finder man i enkelte boringer løst lejret smeltevandssand. Postglaciale, marine lag er truffet ved Gåsegade og ved Frederiksholm Kanal, hvor de glaciale lag overlejres af en mere end $3 \mathrm{~m}$ tyk, sandet og stenet strandvoldsdannelse. I samtlige boreprofiler findes øverst et 3-4 m tykt fyldlag af varierende sammensætning. En del 
bløde, lerede, tørve- og gytjeprægede sandaflejringer er sandsynligvis postglaciale lag, som er opblandet med fyldmateriale.

Langs Nybrogade og Gl. Strand overlejres prækvartærlagene af ca. $5 \mathrm{~m}$ fast moræneler, som nogle steder præges af smeltevandsler eller af kalksten og kalkslam fra danienet. Der findes kun sparsomme rester af sandlaget under morænebænken. Fyldlagene er her over $8 \mathrm{~m}$ tykke og overalt meget stenede i den nederste del. Ved Højbro Plads er morænelersbænken kun 2-3 m tyk, og den overlejres af et ca. $3 \mathrm{~m}$ tykt lag af sand og grus, som muligvis er senglacialt smeltevandssand, afsat i den overfor omtalte sidedal til Rådhuspladsdalen. Boringerne på strækningen Højbro Plads - Kgs. Nytorv ligger på sydøstskråningen af denne dal og viser en meget varierende opbygning af kvartærlagene. Syd for dalen finder man højere liggende kalk og mere regelmæssigt opbyggede kvartærserier, ved Nicolajgade således to morænelersbænke med en mellemliggende smeltevandsserie og ved Vingårdsstræde ca. 1,5 m moræneler, der hviler på velsorteret, stenet sand. Mellem Magasin og det Kgl. Teater passerer man en opfyldt voldgrav med op mod $8 \mathrm{~m}$ fyld, der hviler på et tyndt morænelerslag over kalken.

På Kgs. Nytorv findes vekslende kvartære lagserier. Der findes eksempler på to morænelersbænke med en mellemliggende smeltevandsserie, og der er profiler, hvor kalken overlejres af smeltevandsdannelser, som atter overlejres af moræneaflejringer. Et karakteristisk led i lagserien er et ca. 4 m tykt, gruset og stenet lag med partier af moræneler. Det træffes over kote $\div 6 \mathrm{~m}, \mathrm{og}$ er muligvis en bænk af meget lerfattigt moræneler, hvis lerindhold er delvis bortskyllet ved boreprocessen. Som overalt i Den indre by er fyldlaget særdeles tykt, især i de gamle kystområder og over de tidligere fæstningsgrave. Ved Mindeankeret i Nyhavn når fyldlaget i det opfyldte havnebassin muligvis helt ned til kalkoverfladen.

\section{Havnegadetunnelerne}

Den sidste lokalitet i omtalen af Den indre by er tunnelerne under Inderhavnen mellem Christianshavn og Havnegade. Disse tunneler er tidligere omtalt af blandt andre Milthers (1935) og Christensen (1959), men en geologisk opmåling er så vidt vides ikke tidligere foretaget.

Baggrunden for tunnelbyggeriet. Københavns vandforsyning var gennem det meste af byens historie baseret på brønde, spredt over hele byen. Senere hentede man vand fra omegnens søer. Et led i forsøgene på at skaffe rent og sundt vand fra undergrunden var den ca. $185 \mathrm{~m}$ dybe boring på Frederiksholm, kaldet Nyholmboringen og bekostet af Videnskabernes selskab (1831-48). Nyholmboringen er omtalt af blandt andre Rosenkrantz (1925, pp. 


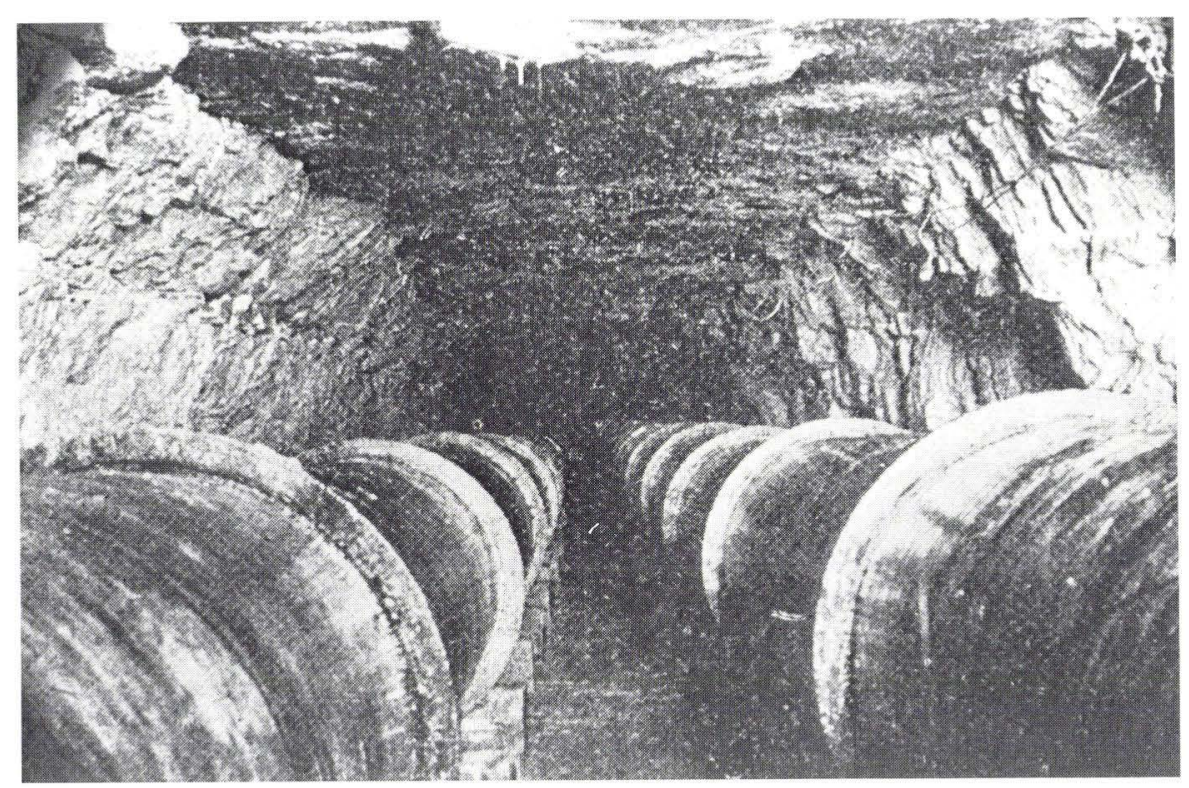

Fig. 52: Havnegadetunnelerne. Den »nye « tunnel ca. 1900. Loftet er undersiden af en kalkbænk. Venligst udlånt af Alfred Rosenkrantz.

Fig. 52: The Havnegade tunnels. The "new « tunnel of c. 1900. The ceiling is formed by a bench of indurated limestone. Courtesy of Alfred Rosenkrantz.

5-6). Boringens historie og baggrunden for hele projektet er udførligt beskrevet af Lomholt (1960, pp. 343-359).

I midten af forrige århundrede begyndte man at forsyne byen med vand, der $\mathrm{i}$ åbne render ledtes ind fra boringer i omegnen, og i 1854 vedtog borgerrepræsentationen at give hovedstaden et vandværk, et gasværk og et kloaksystem. Den engelske ingeniør James Simpson foreslog at samle vand- og gasledningerne til Christianshavn i et stort beskyttende jernrør under havnen. Vandinspektør, senere stadsingeniør L.A. Colding fik gennemført, at man i stedet lagde ledningerne i en tunnel i kalken under havnen, og i januar 1858 gennembrød Colding personligt den sidste kalkmur mellem de to tunneldele, så at han i selskab med blandt andre professor Forchhammer kunne spadsere under havnen fra København til Christianshavn.

Tunnelanlagget. Den ældste af tunnelerne er udført i årene 1856-58, den yngste i år 1900 (fig. 52). Mellem disse tunneler findes fire forbindelses- eller sidetunneler. Hovedtunnelerne er ved lodrette skakte forbundet med gadeniveau i hhv. Havnegade ved Peder Skramsgade og ved Gammel Dok på Christianshavn. Placeringen fremgår af situationsplanen, fig. 53, der tillige viser beliggenheden af de i tunnelens nærhed udførte boringer. 


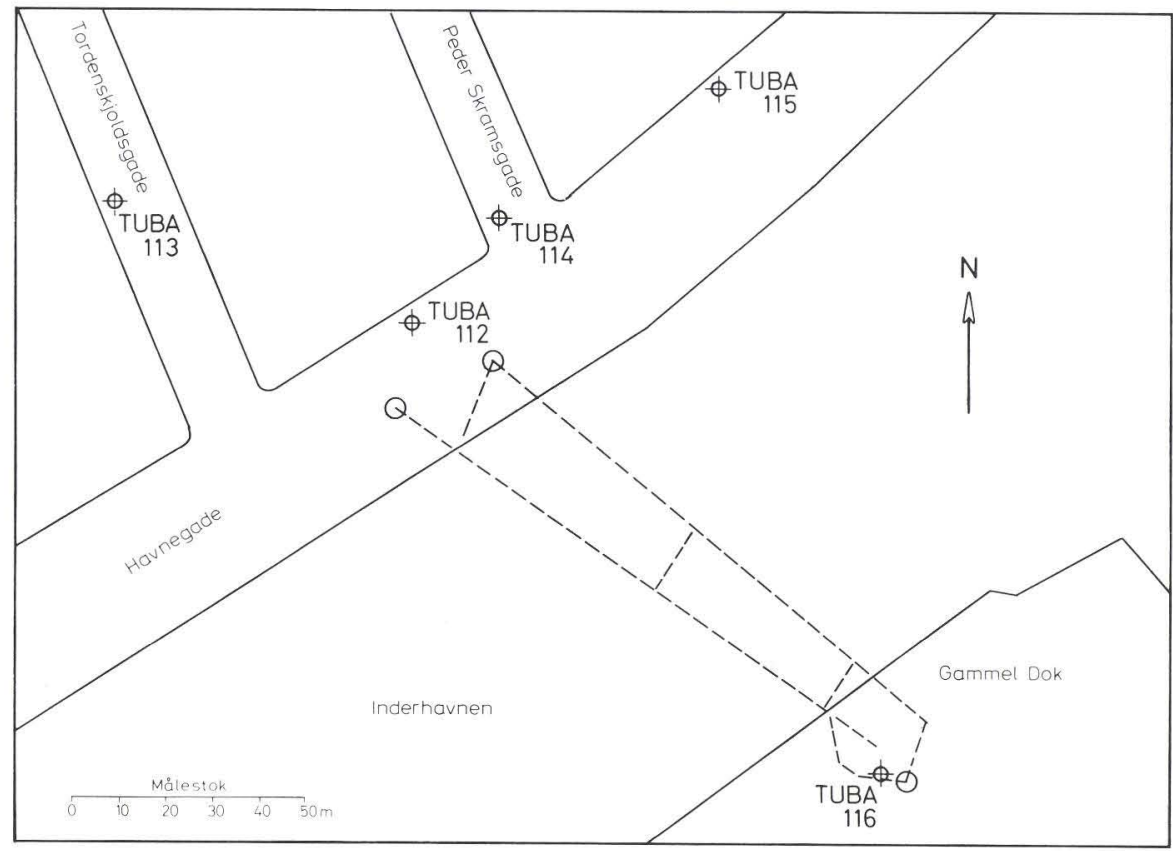

Fig. 53: Havnegadetunnelerne. Situationsplan visende beliggenheden af Havnegadetunnelerne (stiplet) og omliggende prækvartærboringer. Efter Stenestad (1971 a).

Fig. 53: The Havnegade tunnels. Map showing location of the Havnegade tunnels (dashed lines) and nearby boreholes penetrating to the Pre-Pleistocene deposits. According to Stenestad (1971 a).

Opmåling. Tunnelanlægget blev besøgt og delvis opmålt af forfatteren i vinteren 1970-71. Opmålingen blev foretaget på samme måde som ved Sydhavnstunnelen. De opmålte profilers beliggenhed fremgår af fig. 54 øverst . Længdesnittet af den ældste tunnel (GT) er vist nederst fig. 54, medens et længdesnit af forbindelsestunnel $\varnothing \mathrm{T}$ er vist fig. 55. Ved besigtigelsen var opmærksomheden rettet mod lagstillingen, flintlagenes udseende og forløb, kalkens karakter og hærdningstilstand, sprækkernes art, størrelse og vandf $\varnothing$ ring samt mineraludskillelser.

Lagstilling. Tunnelvæggene var dækket af et rødbrunt, 2-5 mm tykt overtræk af mineraludskillelser, der fuldstændigt tilslørede kalkoverfladen, og som nødvendiggjorde, at væggen blev afrenset (ved hugning), hvis man ville se detaljer. Man måtte nøjes med at afrense forholdsvis små arealer, og det var ikke muligt at konstatere en eventuel primær lagdeling. Kalken er overalt tydeligt bænket og gennemsat af 2-3 kraftige flintlag, der kan følges såvel i hovedtunnelerne som i forbindelsestunnelerne. En stærkt hærdnet kalkbænk 


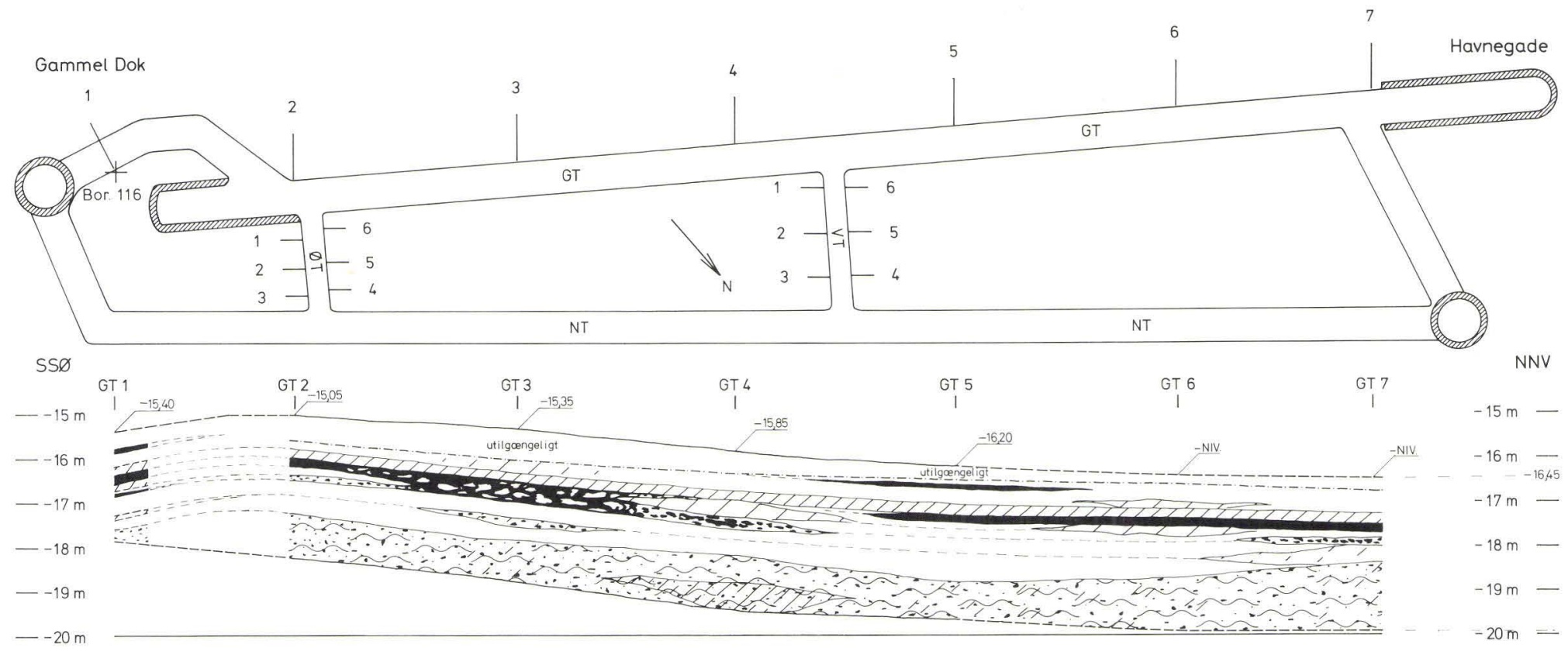

Kalksandskalk,
uherdnet-let herdnet

$\square$ Flintlag $\quad \because \because$ Flintknolde

Kalksandskalk,

Målestok 

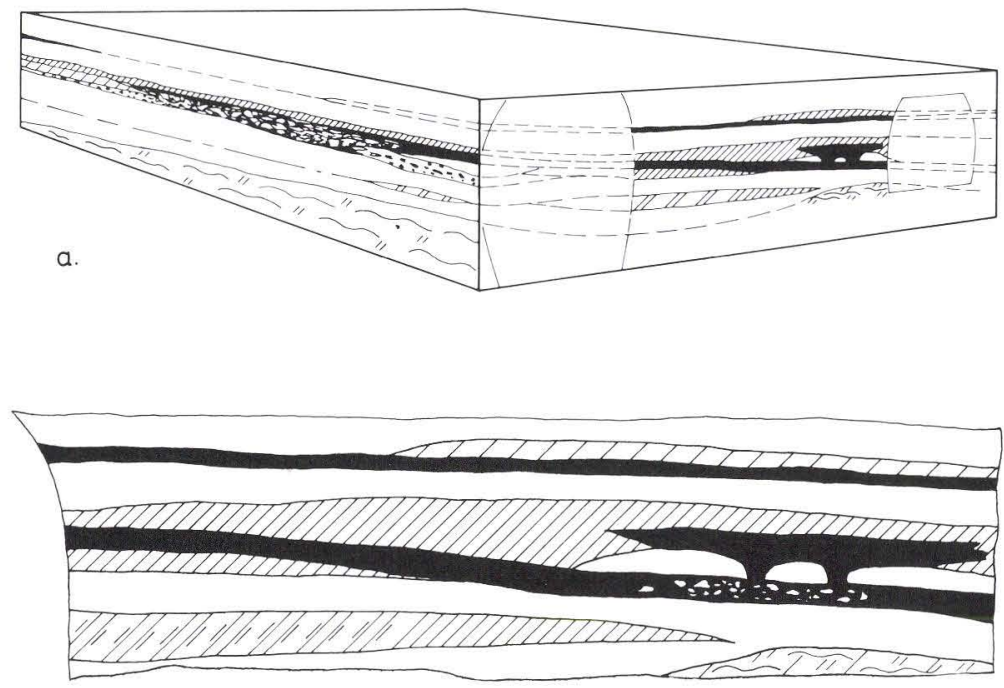

b.

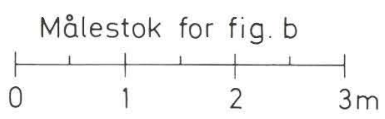

Fig. 55: Havnegadetunnelerne. Blokdiagram (a) visende længdesnit (fig. 54) og snit af østlige forbindelsestunnel (ØT), der tillige er vist nedenfor (b). Bagest i blokdiagrammet ses den »nye « tunnel (NT), vist på fotografiet, fig. 52. Opmålt af forfatteren. Signaturer som på fig. 54. Efter Stenestad (1971 a).

Fig. 55: The Havnegade tunnels. Diagram showing vertical sections of tunnels GT and $\varnothing T$, which are given in detail figs. 54 and 55. Fig. 52 shows the tunnel NT, also shown in the diagram. Signatures as in fig. 54. Surveyed by the author. According to Stenestad (1971 a).

danner loft. Kalk- og flintbænkene er svagt bølgende og ganske svagt hældende i retning mod Havnegade, dvs. i nordvestlig retning. Det ser ud til, at den bioturberede København Kalks overflade og grænsen mellem den øvre og den nedre foraminiferzone hælder svagt i samme retning. Dette, og det forhold, at der ikke er iagttaget hverken små eller store forkastninger eller egentlige knusningszoner, tyder på, at lagserien er nogenlunde uforstyrret.

Flint. Flinten er i overvejende grad af den lysegrå, kalkholdige, tætte type. Den forekommer dels som spredte, små konkretioner, dels som sammen-

Fig. 54: Havnegadetunnelerne. Plan og længdesnit af sydvestvæg i den ældste tunnel (GT), ifølge forfatterens opmåling. Efter Stenestad (1971 a).

Fig. 54: The Havnegade tunnels. Plan and vertical-section surveyed by the author. According to Stenestad (1971 a). 
hængende lag, hvis overside er regelmæssig, jævnt bølgende, medens undersiden kan være mere uregelmæssig. Nogle steder var der kegleformede strukturer i flintlagene, »flinttragte«, fig. 55 , som nåede ca. $1 / 2 \mathrm{~m}$ ned $\mathrm{i}$ den underliggende kalk. Det er muligt, at disse flintdannelser er stærkt omdannede forsteninger eller sporfossiler, eventuelt Paramoudra (Bromley et al. 1975), men ved besigtigelsen bemærkedes intet tegn på organisk oprindelse. Der skal her peges på den mulighed, at de helt usædvanligt tykke flintlag, man lejlighedsvis træffer i boringerne, eventuelt repræsenterer spredte, lokale fortykkelser af flintlag, f.eks. dannelser som de her beskrevne. Rørdam (1897, p. 25) omtaler lignende forhold fra Frederiksholms teglværks grav.

Kalkens karakter og hardningstilstand. Kalken er, såvel i tunnelerne som i boringerne i disses nærhed, af den almindelige, meget finkornede kalksandskalktype. Den synes i den $\emptyset$ verste del af tunnelvæggene at være særdeles regelmæssigt udformet uden lerslirer og overvejende let hærdnet med velafgrænsede bænke af hærdnet og stærkt hærdnet kalk samt flint. Nederst i tunnelvæggene er der på visse strækninger konstateret en noget mere uregelmæssig fordeling af hærdning og flint (fig. 54 og 55). Disse lag tilhører antagelig den bioturberede København Kalk. Af boringerne i nærheden af tunnelerne når kun TUBA 116 igennem de lag, hvori tunnelerne ligger. Den er placeret mindre end $1 / 2 \mathrm{~m}$ fra tunnelvæggen ved profil GT 1 , og den viser, at den bioturberede kalk fortsætter ned under tunnelen, hvad der støtter den anførte opfattelse af, at den bioturberede København Kalks overgrænse findes nederst i tunnelerne.

Sprckker og vandtilstrømning. Sprækkerne i kalken følger bænkningen, optræder i parallelt orienterede sværme eller er tilfældigt orienterede. Bænkningssprækker og tilfældigt orienterede sprækker findes overalt, men parallelt orienterede sprækkesystemer er kun set enkelte steder, mest typisk i den nye hovedtunnel (NT) i nærheden af den østre forbindelsestunnel (ØT), hvor loftet er præget af sværme af nordvest-sydøst orienterede lange sprækker. Der ser ikke ud til at være sket nogen forskydning langs disse sprækker. Bænkningssprækkerne er ganske smalle, medens de øvrige sprækker kan være flere millimeter brede. Bænkningssprækkerne kan i nogle tilfælde være over hundrede meter lange, medens længden af de øvrige sprækker ikke har kunnet vurderes i tunnelerne.

Vandet fosser overalt ud af sprækker i loft og vægge. Det var ikke ved besigtigelsen muligt at afgøre, om en af de nævnte sprækketyper var kraftigere vandførende end de andre. Tunnelvæggene var som omtalt dækket af rødbrune mineraludskillelser, antagelig jernforbindelser. Ved vandets indstrømning i de tørlagte tunneler dannedes store, hvide, bløde belægninger under de vandførende sprækker. Særligt indtryksgivende sås dette i den nye hovedtunnel (NT), hvor vandets indtrængen på undersiden af de to gennem- 
gående flintlag var markeret af lange striber af hvide belægninger på rødbrun baggrund. Kun på overfladen var belægningerne hvide, nedenunder var de blåsorte. De viste sig at indeholde 35-40\% svovl, og langt den overvejende del af dette var elementært svovl (kloroformopløseligt). Det store svovlindhold stammer antagelig fra reduktion af sulfater i det indtrængende havvand. Tilsvarende observationer er gjort i Svanemølletunnelen (fig. 58).

\section{Området mellem Kgs. Nytorv og Østerport Station}

Fra Kgs. Nytorv til Grønningen (fig. 18) har kalklagene et på det nærmeste horisontalt forløb. Dette er også tilfældet i området mellem Bredgade, Frederiksgade og Adelgade (fig. 19). Mellem Grønningen og Østerport Station er forholdene dårligere kendt som følge af færre observationspunkter.

Bryozokalkenheden. Bryozokalkenheden er, som i Den indre by, rig på slamkalk og bryozokalken er stedvis særdeles fattig på bryozoer. Omlejrede lag, der er præget af sammenskyllede skalfragmenter, lerlag og kalksand, (kalkarenit), er almindelige. Bryozokalkenhedens overgrænse findes i noget varierende dybder, de fleste steder mellem kote $\div 45 \mathrm{~m} \mathrm{og} \div 50 \mathrm{~m}$. Det forholdsvis beskedne antal observationer giver noget usikre forestillinger om grænsefladens form i dette område.

København Kalk. København Kalken består af de samme bjergarter, som er fundet i de tilgrænsende områder i det østlige København. Øverst er kalken regelmæssigt lejret. Længere nede er den bioturberet og hærdningen varierer stærkt inden for korte afstande. Nederst er lejringen atter regelmæssig og hærdningen mere ensartet, men her er til gengæld lerindholdet ret stort.

Grænsen mellem den $\emptyset$ vre og den nedre foraminiferzone ligger mellem kote $\div 12$ og $\div 13 \mathrm{~m}$, med tendens til lidt lavere beliggenhed længst mod nordøst. Den bioturberede København Kalks overgrænse ligger igennem hele Bredgade i kote $\div 19 \mathrm{~m}$. Fra den nordlige ende af Bredgade (TUBA 61) falder den imidlertid ca. 1,8 m i retning af Grønningen (TUB A 64). På samme strækning falder kalkoverfladen ca. 1,7 m. Danien-selandien grænsen har haft et lidt større fald end 1,7 m, idet den øverste del af København Kalken er borteroderet i TUBA 61. Tilstedeværelsen af gange, udfyldt af Lellinge Grønsand tyder dog på, at kun ganske lidt er fjernet, hvad der også støttes af, at den øvre, regelmæssigt lejrede København Kalk er lige tyk i de to boringer (ca. $12 \mathrm{~m}$ ) og lader sig korrellere ret nøje. Da de to profiler (TUBA 61 og 64) er så ens, og da der kan konstateres en højdeforskel imellem dem, må det overvejes, om der er en forkastning mellem boringerne, eller om lagene blot hælder lidt stærkere her, end det ellers er tilfældet i dette område. Ved den samlede vurdering af 
strukturforholdene er fremsat den opfattelse, at de svagt hældende lag er ramt af en forkastning (D) med ganske ringe springhøjde. Forkastningen er skråtliggende og rammer den bioturberede København Kalk i TUBA 64, idet bryozokalkenhedens overflade $\mathrm{i}$ denne boring findes i den forventede dybde, måske endda lidt højere.

Lellinge Grønsand. I boringer ved Frederikskirken findes 4-6 cm tykke erosionsrester af grønsandskalk og bundkonglomerat. I boring TUBA 64 på Grønningen ved Hammerensgade fandt man denne lille lagserie:

$$
\begin{aligned}
& \div 8,00-\div 8,20 \mathrm{~m} \text { Mergelsten, hærdnet, med } \\
& \text { grønsandsfyldte gange. } \\
& \text { - } \div 8,90 \mathrm{~m} \text { Mergelsten, hærdnet, med lerlag } \\
& \text { ved } \div 8,3 \mathrm{~m} \mathrm{og} \div 8,9 \mathrm{~m} \text {. } \\
& -\div 8,97 \text { m Grønsandskalk, stærkt hærdnet. } \\
& -\div 9,01 \mathrm{~m} \text { Bundkonglomerat. }
\end{aligned}
$$

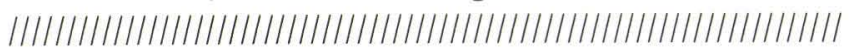

$$
\begin{aligned}
& -\div 9,30 \mathrm{~m} \text { Flint med grønsandspartier } \\
& \text { og pyrit. } \\
& \text { - } \div \text { 9,75 m Kalksandskalk, stærkt hærdnet, } \\
& \text { med grønsandsfyldte gange. }
\end{aligned}
$$

Lellinge Grønsandets nederste del er normalt meget kalkrig, men i TUBA 64 er kalkindholdet usædvanlig stort. Mergelstenen øverst i profilet er i virkeligheden en let leret, finkornet udgave af konglomeratet og grønsandskalken. Foraminiferindholdet bekræfter, at det er dannet som det sidste led i en lagserie, der er stærkt præget af sammenskyllet materiale. Det hidrører især fra den allerøverste, borteroderede del af København Kalken, men indeholder tillige materiale fra øvre kridt og små mængder selandienmateriale. De grønsandsfyldte gange viser, at der over mergelserien har været en kalkfattigere, glaukonitisk sandserie, som er fjernet ved senere erosion. Grønsandsfyldte gange er tillige fundet øverst i København Kalken ved Frederiksgade og Grønningen, hvad der bekræfter formodningen om, at hele området oprindeligt har været dækket af Lellinge Grønsandets aflejringer.

Prakvartaroverfladen. Kalkoverfladen ligger mellem Kgs. Nytorv og Grønningen i kote $\div 7-\div 9 \mathrm{~m}$. Der findes kun to områder, hvor den når op over kote $\div 7,5 \mathrm{~m}$, nemlig kvarteret mellem Borgergade, Dr. Tværgade, Bredgade og Grønningen og et mindre område ved havnen omkring Kvæsthusbroen og Larsens Plads. Der er ikke set tegn på tilstedeværelsen af større erosionsdale, men der kan anes en flad lavning i kalkoverfladen mellem de to nævnte højdeområder. På strækningen Grønningen-Østerport Station falder prækvartæroverfladen til kote ca. $\div 10 \mathrm{~m}$. 
Kvartarlagene. I den nordlige ende af Bredgade og ved Østerport Station finder man 2 morænelersbænke med en mellemliggende smeltevandsserie. Den nedre morænelersbænk mangler uden for disse områder. Den øvre morænelersbænk er da til gengæld ofte noget tykkere og smeltevandsserien hviler direkte på prækvartæroverfladen. Den øvre morænelersbænk mangler stedvis i området ved Frederikskirken. Moræneleret er meget sandet og står stedvis på grænsen til morænesand. Smeltevandsserien er i dette område mange steder opbygget således, at man finder det finkornede materiale $\varnothing v e r s t$ og det grusede og mest stenede længst nede.

I kvarteret mellem Frederikskirken og Adelgade viser den kvartære lagserie en stadig vekslen mellem lerede, sandede og stenede lag. Den $\varnothing v r e$ morænelersbænk kan følges mod vest, hvor den aftager i mægtighed.

I området mellem Bredgade og Østerport Station, hvor kalkoverfladen ligger relativt lavt, er den kvartære lagtykkelse større end i de øvrige områder. Der er her en kraftig indblanding af silt og finsand, som muligvis hidrører fra oparbejdede selandienaflejringer.

Senglaciale aflejringer er ikke med sikkerhed påvist. Postglaciale dannelser $\mathrm{i}$ form af tynde, limniske gytjelag er fundet omkring kote \pm 0 i nærheden af Esplanaden, og nogle humøse sandlag omkring kote \pm o ved Dr. Tværgade kan være marine. Det er dog sandsynligt, at de tilhører fyldlaget. På baneterrænet ved Østerport Station er der nederst i fyldlaget fundet nogle gytjeholdige lag, som antagelig er postglaciale.

Fyldlaget er gennemgående 2-3 m tykt. Ved Østerport Station og mellem Kgs. Nytorv og Esplanaden når fyldlagene ned omkring kote \pm 0 . Ved Grønningen findes en lav bakke, som kun er dækket af tynde fyldlag. Dette skyldes muligvis, at Grønningen indtil omkring århundredskiftet var en del af befæstningsområdet ved Kastellet og derved har undgået den kraftige opfyldning, der har fundet sted i de tilgrænsende byområder.

\section{Svanemøllen}

Til slut i denne områdebeskrivelse vil de tre boringer i Stubbeløbsgade (fig. 20) blive omtalt og vurderet i relation til ældre undersøgelser. Rosenkrantz (1920b) omtaler geologiske og palæontologiske iagttagelser i forbindelse med udgravningen af Orientbassinet (10-meter bassinet) ved Sundkrogen. Harder (1922) omtaler grønsandsaflejringerne i havnebassinet og giver udtryk for den opfattelse, at de tilhører en løs flage af forholdsvis små dimensioner (med en horisontal udstrækning af næppe over nogle få hundrede meter og en maksimaltykkelse på ca. $5 \mathrm{~m}$ ).

Svanemølletunnelen. Kloaktunnelen, der fra Strandvænget løber under 


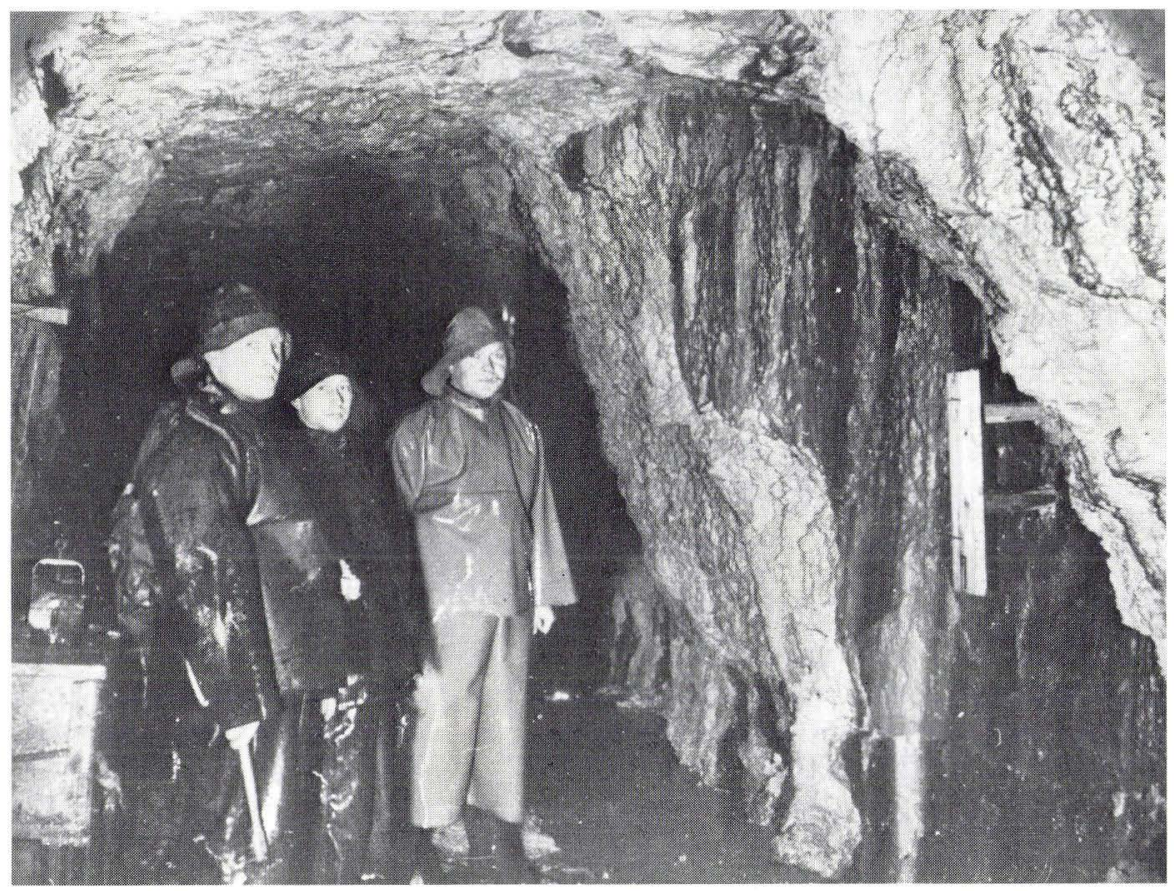

Fig. 56: Svanemølletunnelen. Glideflader og okkerklædte sprækkeflader danner et nordvest-sydøst orienteret system. Personerne er (fra venstre) Th. Sorgenfrei, Bruno Thomsen og Alfred Rosenkrantz. Foto: Chr. Halkier 1943. Venligst udlånt af Alfred Rosenkrantz.

Fig. 56: The Svanemolle tunnel. Sliding-planes and rust-coated joint-planes in a northwestsoutheast system. The persons are (from the left) Th. Sorgenfrei, Bruno Thomsen and Alfred Rosenkrantz. Photograph by Chr. Halkier, 1943. Courtesy of Alfred Rosenkrantz.

Stubbeløbsgade og ud i Øresund, er omtalt af Kerrn-Jespersen (1945) og Forchhammer (1949b). Der foreligger desuden en ekskursionsberetning fra tunnelen (Rosenkrantz 1941). Forud for udførelsen af tunnelen havde man anslået den indsivende vandmængde i den færdige tunnel til ca. $600 \mathrm{~m}^{3} / \mathrm{t}$, men fik, alene fra østtunnelen, $800 \mathrm{~m}^{3} / \mathrm{t}$, og fra vesttunnelen havde man på et tidspunkt en vandmængde på $1220 \mathrm{~m}^{3} / \mathrm{t}$. Nær ved land kom man ind i en stærkt sprækket zone i kalken, og der kom et vandindbrud på $600 \mathrm{~m}^{3} / \mathrm{t}$ fra bunden af tunnelen. Prøveboringer viste, at kalken var stærkt vandførende over en strækning af 150-450 m. Man injicerede med cement, men havde alligevel problemer med indstyrtning af tunnelloftet og ledsagende vandindbrud. Fig. 57, der er optaget af Rosenkrantz i 1943, er fra »den knuste strækning nær land «. Kerrn-Jespersen oplyser (1945 p. A 176), at man på denne strækning måtte støbe en betonhvælvning, og at fotografiet (som 


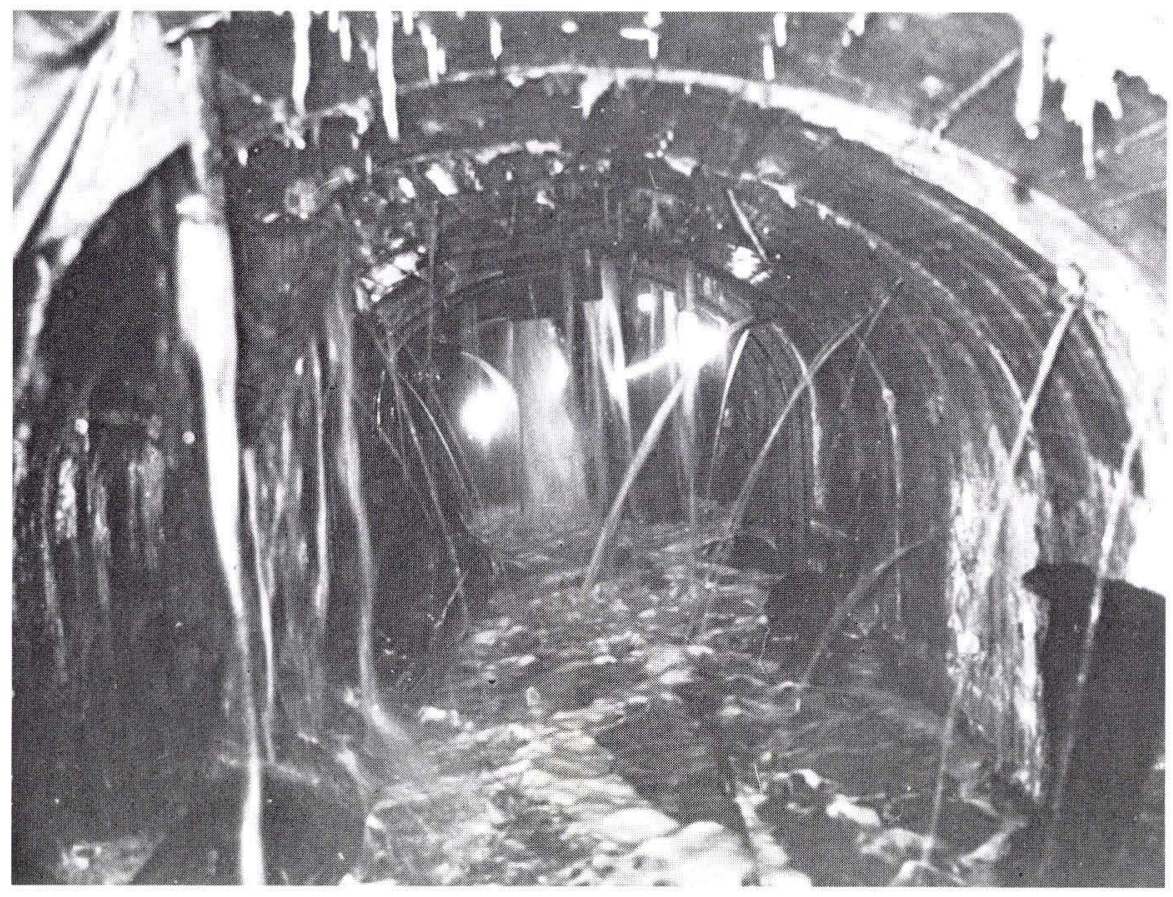

Fig. 57: Svanemølletunnelen. Knust strækning nær land. 1943. Venligst udlånt af Alfred Rosenkrantz.

Fig. 57: The Svanemolle tunnel. Heavy fractured zone in the limestone. Photograph from 1943. Courtesy of Alfred Rosenkrantz.

gengives som fig. 12), viser denne hvælving inden vandindbruddene var tætnet. Metoden fungerede, men den var langsom og kostbar og krævede store cementmængder. Til sidst ændrede man projektet således, at kloaken nu ligger i kalk på strækningen Strandvænget (skakt I) - Stubbeløbsgade (skakt A) og fra den østlige ende af Stubbeløbsgade (skakt B) ud i Øresund, medens den i Stubbeløbsgade mellem skakt A og B er udført som en højtliggende ledning i overjordslagene (fig. 59).

Nye undersøgelser. Erfaringerne fra udførelsen af Svanemølletunnelen var af interesse i forbindelse med citybaneundersøgelsen. Man vidste, at der var stærkt vandførende sprækker i kalken på dette sted og havde derfor en mulighed for at efterprøve de benyttede undersøgelsesmetoders effektivitet m.h.t. påvisningen af sprækkezoner. Der blev udført tre undersøgelsesboringer, TUBA 121, 122 og 123 (DGU nr. 201.3159, 3160 og 3161. Se lokalitetskortet, fig. 1). Boringerne TUBA 121 og 122, der ligger nær $\gg$ den knuste 


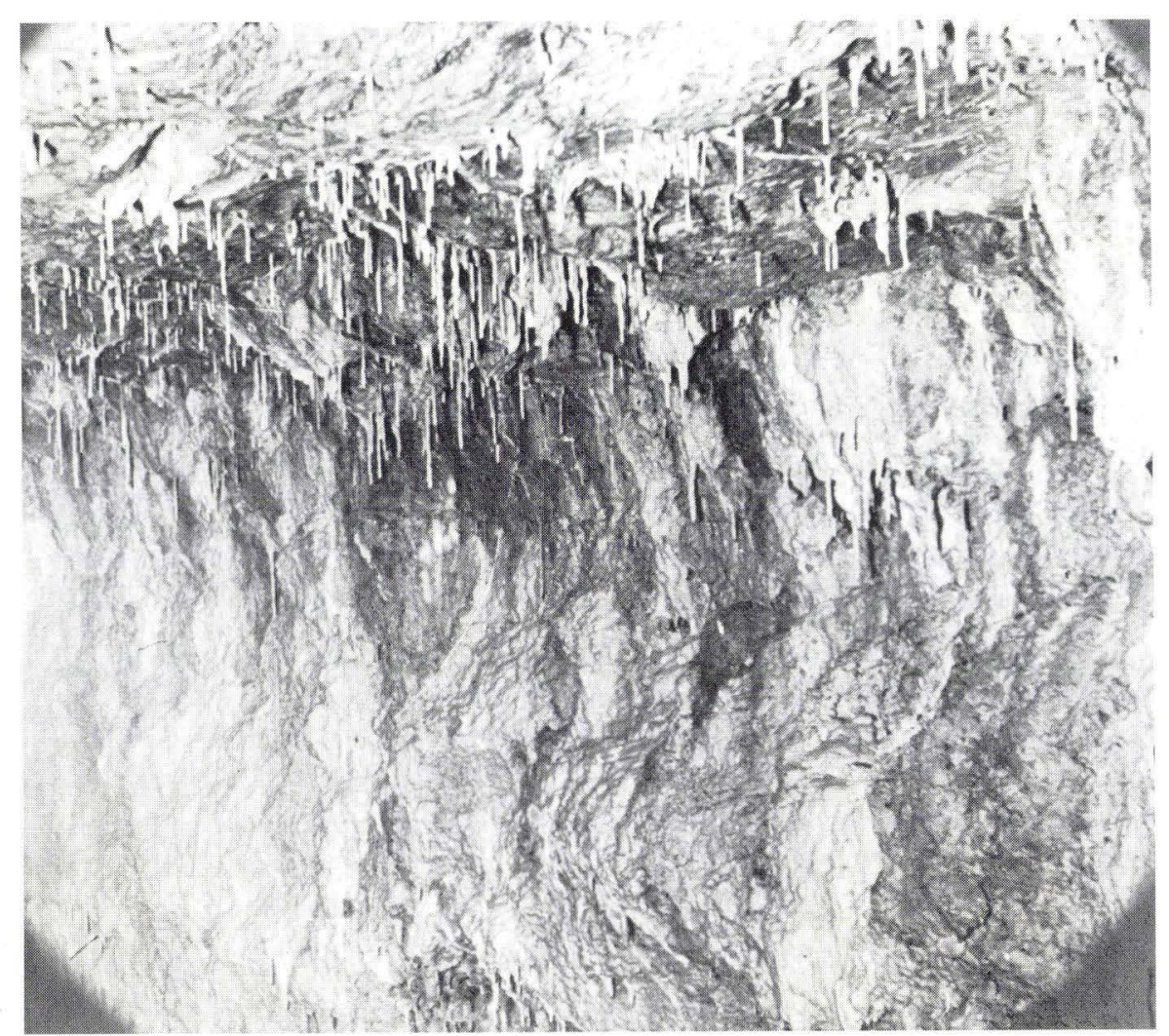

Fig. 58: Svanemølletunnelen. Svovlbakterier danner »drypsten«. Kloaktunnelen ved sejlrenden. Foto: Chr. Halkier, antagelig 1943. Venligst udlånt af Alfred Rosenkrantz.

Fig. 58: The Svanemolle tunnel. Soft, white stalactites" produced by activity of sulphur bacteria. Photograph by Chr. Halkier (presumably 1943). Courtesy of Alfred Rosenkrantz.

zone«, påkaldte sig straks opmærksomheden ved et usædvanlig stort kernetab. Det er dog vigtigt at slå fast, at der ikke er nogen entydig forklaring på fremkomsten af kernetab. Meget sprækkede eller knuste lag vil sandsynligvis give store kernetab, men det samme gælder lag med uregelmæssigt vekslende hærdning, f.eks. let hærdnet kalk med flintknolde eller den bioturberede København Kalk, der er sammensat af uregelmæssigt formede partier af

Fig. 59. Svanemølletunnelen. Plan og længdesnit sammenstillet på basis af Geoteknisk Instituts Specialrapport nr. 1 (1970 a). $\varnothing=$ Subbotina triloculinoides zone. $\emptyset$ vrige signaturer som for fig. 5 .

Fig. 59: The Svanemolle tunnel. Plan and vertical section, complied on the basis of Geoteknisk Institut, Special report 1 (1970 a). $\varnothing=$ Subbotina triloculinoideszone. Other signatures as fig. 5 . 


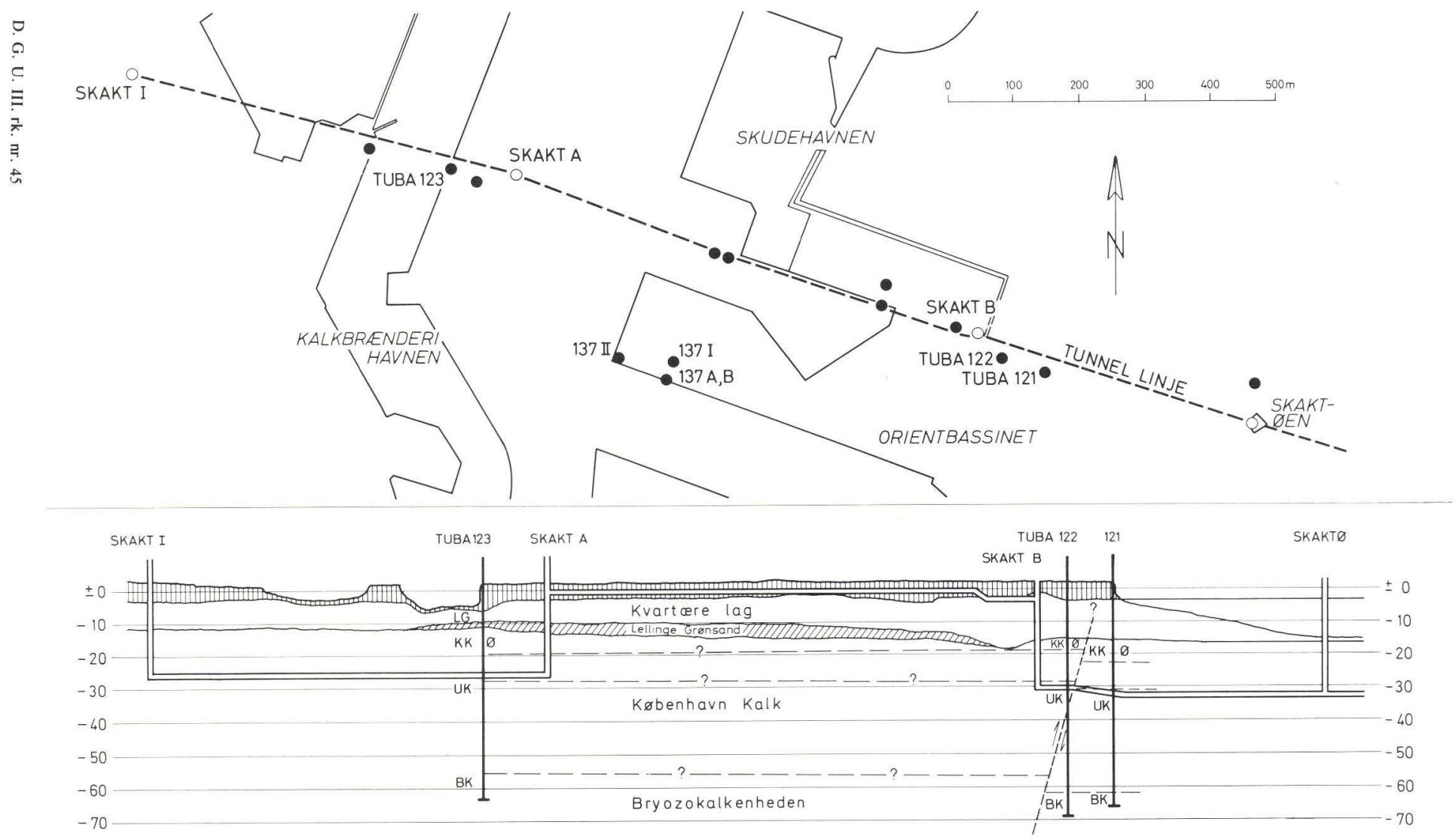

二 Erik Stenestad 1975 
stærkt vekslende hærdningsgrad. I TUBA 123 var kernetabet størst i København Kalkens nedre, ret flintrige afsnit. I TUBA 122 var det derimod stort lige fra den $\emptyset$ verste del af København Kalken og iøvrigt nogenlunde jævnt fordelt over hele profilet. Prøvepumpninger viste (Geoteknisk Institut 1970a), at der må være mange åbne sprækker helt ned til kote ca. $\div 40 \mathrm{~m}$ eller dybere. I TUBA 121 var kernetabet stort i hele afsnittet med bioturberet København Kalk, og det var også ret stort i den nedre, flintrige zone i København Kalken. I den $\varnothing$ vre zone var tabet relativt beskedent sammenlignet med TUBA 122 , men alligevel betydeligt sammenlignet med TUBA 123. Prøvepumpningerne i TUBA 121 viste, at kernetabet i afsnittet med bioturberet kalk formodentlig især må skyldes kalkens karakter og ikke tilstedeværelsen af sprækker.

Lagserien. I boringerne (fig. 20) traf man de samme bjergarter, tilhørende Lellinge Grønsand, København Kalk og bryozokalkenheden med underordnede varianter og med lerede lag, flint- og hærdningslag som i de tidligere omtalte boringer. Ved sammenligning med profilerne fra de $\emptyset v$ rige boringer vil man se, at bryozokalkenheden ligger dybere, og at København Kalken er mægtigere i Svanemøllen end i City. Bioturberet København Kalk udgør, specielt i TUBA 121 og 122, en større del af lagserien i Svanemøllen, men iøvrigt er der mange lighedstræk. Der er således en øvre flintpræget og en nedre flintrigere zone, og den nederste del af København Kalken er mere lerpræget end resten af serien. Den indeholder mergellag og uregelmæssige lerslirer, hvis form i nogle tilfælde skyldes slumpning, i andre tilfælde uensartet sammentrykning omkring hårdere partier i kalken (fig. 25). For TUBA 121 og 122 gælder, at de mangler spor af selandienaflejringer, hvad der må betyde, at de $\varnothing v e r s t e$ meter af kalken er borteroderet.

Lagstilling. Der kan endnu ikke tegnes kort over de referensflader, som er benyttet i City. Det kan konstateres, at lagene generelt ligger dybere i TUBA 121 og 122 end i 123, men lagmægtigheden er større i TUBA 121 og 122, og der er tegn på, at højdeforskellen til TUBA 123 aftager op igennem lagserien. Dette kunne tale for, at lagene blot hælder i østlig retning, og at sprækkezonen i kalken under Stubbeløbsgade kunne være et resultat af istryk og ikke en forkastningszone. Der er dog næppe tvivl om, at der findes en forkastningszone i nærheden af TUBA 122 (fig. 59). Herpå tyder bl.a. den store hydrauliske forskel mellem de nærliggende boringer, og som det fremgår af fig. 56, der viser et nordvest-sydøst orienteret system af okkerklædte sprækkeflader med harniske (glideflader), kan man i tunnelen direkte iagttage, at der er sket vertikale forskydninger af kalklagene. Som vist fig. 59, tyder observationerne på, at forkastningen er revers. Det foreliggende grundlag er dog for spinkelt til, at der kan siges noget sikkert herom.

Sorgenfrei (1959) anfører, at der i Øresund findes to brudlinier, som er parallelle med Rosenkrantz' Carlsbergforkastning. Den ene går fra Prøveste- 
nen til Svanemøllebugten, den anden langs østsiden af Kongedybet med retning mod Kronløbet. Imellem disse forkastninger findes et område, som er nedforkastet 5-10 m i forhold til blokkene vest og øst herfor. Det kan ikke udelukkes, at Svanemølleboringerne, TUBA 121-123, eventuelt kan ligge i det nedforkastede område. Larsen (1966) fremsætter formodningen om eksistensen af en brudlinie langs Amagers østkyst ud for Kastrup. En sådan brudlinie ville passe godt ind i det strukturelle mønster, Sorgenfrei skitserer for området ud for Københavns havn. Det ville også give en enkel forklaring på Lellinge Grønsandets udbredelsesmønster ved Øresundskysten, idet disse dannelser i så fald hovedsagelig er bevaret i nedforkastede områder langs Sjællands og Amagers østkyst. 


\section{Afsluttende bemærkninger}

Citybaneundersøgelsen og de $\emptyset$ vrige her omtalte unders $\emptyset$ gelser har bidraget til en mere detaljeret og præcis viden om de prækvartære bjergarters lithologi, stratigrafi og strukturforhold. En del tidligere fremsatte formodninger er blevet bekræftet, f.eks. at der har været selandienaflejringer i hele Københavns Cityområde, at selandienaflejringerne er faststående i Svanemølleområdet, og at kridtoverfladen i området øst for Carlsbergforkastningen ligger ca. 100-110 m under havoverfladen. Som et resultat af undersøgelserne foreligger en lithostratigrafisk inddeling af den københavnske, prækvartære lagserie samt en biostratigrafisk inddeling af København Kalken, baseret på foraminiferer. Endelig har undersøgelserne bidraget til den geologiske opfattelse af prækvartærlagenes strukturforhold i København og den sydlige del af Øresund.

Denne publikation indeholder resultater af mange institutioners og enkeltpersoners arbejde, og det ville have været vanskeligt at færdiggøre den uden den velvilje og imødekommenhed, alle implicerede parter har vist.

En varm tak rettes til Statsbanerne, Københavns Havnevæsen og Projektorganisation Saltholm, som har stillet oplysninger og prøver fra et stort antal boringer til rådighed.

Tak til Danmarks Geologiske Undersøgelses direktør, dr. phil. Ole Berthelsen for tilladelse til at benytte borearkivets data samt for assistance fra DGU's tegnestue og fotolaboratorium.

Megen tak skylder jeg også afdelingsgeolog Inger Bang, som har bidraget med mange oplysninger om danien biostratigrafi, og Richard G. Bromley, Ph. D., som har bestemt sporfossilerne og gennemset summary.

En række kolleger ved de geologiske institutter i København og Aarhus samt ved DGU har ved saglige diskussioner og konstruktiv kritik bidraget til opgavens løsning. En særlig tak skylder jeg professor dr. h.c. Alfred Rosenkrantz, professor dr. phil. Tove Birkelund, professor dr.phil. Gunnar Larsen, statsgeolog dr.phil. Helge Gry og cand.scient. Erik Broe Nielsen. 


\section{Summary}

\section{Geology of the Copenhagen area predominantly based on in- vestigations for an urban underground railway}

\section{Introduction}

Since the beginning of the 1940s, various plans have been produced for an underground railway in Copenhagen. In June 1967 an act of parliament concerning the construction of an underground line through the city gave rise to rather extensive drilling activity. The results of the investigations were published in a series of reports which dealt particularly with the technical problems. Many geological observations were omitted from these reports since they had no bearing on the technical arguments. The aim of the present publication therefore is to present the geological observations from the city-line borings and to put them in relation to other observations, both new and old, from the Copenhagen area.

Previous investigations of the geology of Copenhagen led to the assumption that the subsurface Pre-Pleistocene rocks were divided into large fault bounded blocks, several kilometres in diameter. These blocks represented larger or smaller parts of the Cretaceous-Tertiary sequence. Two borings had shown the top of the Cretaceous White Chalk to be situated 110-121 metres below sea-level. The overlying Danian limestone sequence was thought to have an average thickness of about 100 metres. The lower part of the Danian was mainly constituted of bryozoan limestones, whereas the upper part was composed of calcarenites.

The Danian deposits were known to be superimposed by glauconitic limestones, sands and marls from the Palaeocene (»Selandian«). The Selandian deposits were at least 6 metres thick (Gry 1935, p. 19, 21), but they had been removed by glacial erosion over large parts of the area and were chiefly found in two areas near the South harbour and the North harbour respectively.

The glacial erosion by Weichselian and other glaciers left the Pre-Pleistocene surface with glacial striae indicating three directions of ice movements: NE-SW, NW-SE and N-S. The glaciers left an upper and a lower moraine of clayey till, separated by glaciofluvial sands and gravels. The lower moraine is known to contain reworked interglacial material. 


\section{Material}

During the years 1967-1973, 205 boreholes were made for the underground railway. Most of these were geotechnical borings with high quality sampling. All drill-work in the Pre-Pleistocene was accomplished by diamond drilling, producing continuous cores. 126 borings terminated in the calcarenitic upper part of the Danian limestone sequence, and 23 borings in the upper part of the underlying bryozoan limestone sequence. One of the borings, TUBA no. 13 (Geological Survey, file no. 201, 3080) was conducted through the total Danian sequence and 25 metres into the the subjacent Maastrichtian White Chalk.

As will be seen from the location map (fig. 1), the city-line boreholes are situated in a narrow belt running southwest-northeast through the town. While this distribution is unfavourable from a structural point of view, this drawback is to some extent counteracted by the extreme accuracy of the sampling, which nevertheless allowed a structural model for the Copenhagen region to be made. This was achieved also by incorporation of data from about 3000 other boreholes in this area, made for water-supply and various technical purposes during the past century.

Useful information concerning bedding and fracturing of the uppermost part of the Danian limestone was obtained from three service-tunnels in the South, Central and North harbours. In these tunnels, slightly undulating beds of soft and indurated limestone alternate with beds of massive flint with an average thickness of 10-20 centimetres. These beds of flint form coherent lenses with a diameter that may exceed 200 metres.

\section{Methods}

The samples from the older borings were described by geologists of the Geological Survey (D.G.U.) and others and have not been re-described. The samples from the city-line borings were described by a team of geologists from D.G.U., E.L. Mertz and H. Bahnson (Quaternary), and the author assisted by H.H. Jensen (Pre-Pleistocene). I. Bang made the biostratigraphical investigations of the Danian samples. The biostratigraphical zonation of the White Chalk in TUBA 13 was undertaken by the author. Two of the service-tunnels mentioned were surveyed by the author.

All samples from the city-line borings were treated in the same way. First they were surveyed and described lithologically and small samples were selected for biostratigraphical and geotechnical analyses. The biostratigraphical investigations were conducted independently of all other investigations in order to avoid any interaction. The two sets of conclusions were not compared until the final phase of the work. Thus the concordant results are believed to be significant. 


\section{Lithology and stratigraphy}

Maastrichtian. The White Chalk unit is not yet defined as a formal lithostratigraphical unit. The upper boundary is well known from the informal type locality at Stevns Klint (Sorgenfrei 1957), but a lower boundary has not been established. From the deeptests throughout Denmark it is known that the soft White Chalk grades downwards into marly, indurated limestones, but no significant lithological break is found within the main part of the Upper Cretaceous in The Danish Embayment. This illustrates very well the monotony that characterizes the Danish White Chalk.

The chalk in the sole section, borehole TUBA 13 (fig. 5), is in general slightly indurated, but small inclusions of soft micrite and silicified limestone may occur. Flint nodules are not very abundant. The flint is grey, non-porous and slightly calcareous. The slight induration and the small amount of flint, which contrast with Danian lithology, are believed to be typical for the White Chalk of the Danish on-shore.

The upper part of the TUBA 13 chalk is soft and pure white, but grades downwards into chalks with visible trace-fossils (»Bänderkreide « of Voigt and Häntzschel 1956). The undamaged burrows demonstrate that the bioturbated chalk in general has not been disturbed otherwise, although some erosion must have taken place. At 119.3 metres below sea-level (some 16 metres below the top of the chalk) a 5 centimeter thick bed of marly chalk is found, which contains angular, partly broken lumps of slightly lithified chalk and small irregular lenses of soft lime-mud (fig. 2). This bed is believed to be a slump-bed. The angular, partly broken lumps of slightly lithified chalk indicate transport over short distances. According to Håkansson et. al. (1974) and others, slumping and sediment flow cease prior to the conclusion of the early diagenetic phase.

The Maastrichtian-Danian boundary. The lithology of the Maastrichtian-Danian boundary is not uniform within the region around the Sound (fig. 3). At Stevns Klint the uppermost part of the chalk is greyish and faunistically different from the subjacent white chalk. It is rich in fossils and its depositional environment was one of bryozoan bioherms. In the basins between the bioherms, the lowermost Danian fish clay and cerithium limestone occur. The tops of the Cretaceous bioherms and the cerithium limestone were eroded and transformed into a hardground (of early Danian age), on which the Danian bryozoan limestones were built up. A hardground (DA 4) in the lowermost part of the Danian at Limhamn (fig. 3) was correlated with the Stevns hardground by Brotzen (1959 p. 19), but not by Ødum (1971), who did not find such hardgrounds in nearby borings at Skanör.

In TUBA 13 from Copenhagen the top of the Maastrichtian chalk is a fine-grained, strongly indurated limestone, with calcite cemented high-angle 
fractures and with glauconite grains. There are many irregularly formed Thalassinoides burrows, which are filled up with rather coarse, glauconitic calcareous material. The junction is therefore apparently developed as a hardground. These burrows have a Danian foraminiferal fauna (Bang, in: Mertz et. al. 1969). Beneath the hardground the chalk is but slightly indurated. Strongly indurated chalk and cavities infilled with glauconitic material may occur near to the hardground. On top of the hardground rests a sequence of limestones with a Danian foraminiferal fauna. In this boring the greyish chalk, the fish clay and the Cerithium limestone were not found. This means that TUBA 13 is situated in a location where these sediments have been removed by erosion or were not deposited.

On the island of Saltholm (fig. 3), four core-tests performed in 1975 showed the top of the chalk to be brecciated (fig. 4). In two boreholes the lowermost part of the Danian sequence demonstrated slumping. A hardground was present only in borehole 12 (fig. 4), where two or possibly three early Danian sedimentational breaks may be traced.

The fine detail of the Maastrichtian-Danian boundary in this area varies somewhat. It seems likely that extensive regression - transgression movements were a common event, but under different local conditions the general development led to a variegated facial pattern. Some of the local effects may be due to tectonic movements. At Saltholm, for instance, the above-mentioned observations might be explained through the assumption of small-scale movements in a structural high on the eastern part of the island.

Danian (Lower Palaeocene). Danian deposits are present in all parts of the Copenhagen area. In the mapped area their thickness ranges from approximately 90 to 110 metres. In the borehole TUBA 13 (figs. 3 and 5), which gives a complete section through the Danian, the total thickness is 92.4 metres.

Rosenkrantz (1937) divided the Danian sequence into three units, separated by erosional unconformities. This classification was sustained by Sorgenfrei (1957). The lower unit incorporates the fish clay and the Cerithium limestone at Stevns. The middle unit includes the coral limestone at Fakse and the bryozoan limestones in eastern Sealand and northern Jutland. The upper unit comprises the calcarenites and calcilutites in the same areas.

In the area described here, the Danian deposits may be referred to the upper and middle unit. The lower unit may be present on Saltholm (borehole no. 14). In this publication an upper calcarenitic unit, here defined as the København Limestone, and a lower bryozoan limestone unit are distinguished (fig. 29).

The Bryozoan Limestone unit. The complete sequence is known from the above-mentioned borehole TUBA no. 13 and the Saltholm borehole no. 12 (fig. 3). Parts of the sequence are known from other boreholes in the Copen- 
hagen area. 22 of the city-line boreholes gave information from the uppermost part of this unit.

The Copenhagen Bryozoan Limestone unit is characterized by calcilutites and bryozoan limestones which are very rich in lime mud. Subordinate intercalations of calcarenites and of stratified bryozoan limestones may occur. The lower part of the unit is characterized by calcilutites with clayey intercalations.

As a general rule, clayey intercalations in this unit seem to be connected with the ooze-limestones. Flints are subordinate in the Bryozoan Limestone unit.

The boundary between the Bryozoan Limestone unit and the Kobenhavn Limestone. In nearly all the above-mentioned borings in Copenhagen and on Saltholm, the boundary is marked by a hardground, but in two of the borings it is obscured by beds of flint. It should be mentioned that I. Bang has checked the boundary in the borings by means of the foraminiferal faunas. It therefore seems to be a general feature that the boundary is characterized by a break in sedimentation, usually accompanied by a hardground. Rather rarely, conglomerates or beds of flint may occur. In the border zone, glauconite grains are normally present. It is believed that the lithology of the boundary is clearly marked throughout the area.

The Kobenhavn Limestone. New formation. The uppermost part of the København Limestone is known from quarries, excavations and borings. A total of about 500 boreholes, including some 175 city-line diamond-drill holes, have demonstrated that this unit comprises a calcarenitic-calcilutitic sequence. According to Nielsen (1967), grains exceeding 63 microns amount to 20.7 \pm 6.0 percent of the limestones in TUBA 13 .

The lower part of the sequence is relatively rich in clay and regularly bedded. The middle part is irregularly bedded through bioturbation by unusually irregular Thalassinoides. The upper part is regularly bedded, faintly stratified and poor in clay. These three units are considered to be informal members.

The limestones may be unhardened, e.g. in voids in flintnodules, or they may be indurated by calcite cementation or silicification. Strongly hardened and less hardened limestone benches alternate with thick, massive beds of flint, which generally comprise 10-20 percent of the sequence.

The irregular bedding of limestones of the middle part of the unit may be due chiefly to bioturbation (figs. 23, 24, 26).

In contrast to the main part of the Danian sequence, the uppermost part of the København Limestone contains reworked Maastrichtian foraminifera. This has been reported from Limhamn (Brotzen 1945) and from Copenhagen (Bang, in: Mertz et al. 1969 and later publications), and it indicates that 
Cretaceous deposits were eroded during the sedimentation of the uppermost part of the København Limestone. The source area may be Scania or areas to the south and west of Copenhagen.

On the basis of the present data the upper limestone unit is defined formally:

Kobenhavn Limestone. New formation.

Name: From the Danish name for Copenhagen.

Type area: Eastern part of Copenhagen.

Type locality: Borehole TUBA 13, Geological Survey File no. 201, 3080, the interval 11.1-50.25 metres below sea-level.

Diagnostic features: Micritic limestones with about 20-30 percent lime-sand and lime-silt particles, and with a small amount of clay, which gives the limestone a light grey color. The limestone is weakly stratified and the amount of flint, forming extensive coherent lenses, is rather high (10-20 percent). Irregularly bedded limestone and flint may occur, especially in the middle part of the unit.

Boundaries and contacts: The København Limestone overlies the Bryozoan Limestone unit and is overlain by the Lellinge Greensand (see below). The boundaries are marked by erosion surfaces, usually with the development of hardgrounds. The upper and lower boundary levels are mapped in figs. 39 and 43 .

Geographical distribution: Parts of Northeast Sealand, the island of Amager and the southern parts of the Sound north, west and south of Saltholm, including the northwestern part of this island.

Thickness: About 40 metres. At the type locality 39.2 metres, at Svanemøllen at least 44 metres.

Age: Danian. The upper part of the Globoconusa daubjergensis zone, the Subbotina triloculinoides subzone (Troelsen 1957).

Correlations: The København Limestone may be correlated with parts of the Danian in Scania, in North Jutland and in the North Sea.

Selandian (Middle Palaeocene). Glauconitic limestones, sands and marls overlying the Danian limestones in the Copenhagen area are referred to the Lellinge Greensand, a rock-stratigraphic unit of the Middle Palaeocene. The Lellinge Greensand has not been formally defined, even though detailed investigations by Rosenkrantz, Gry and others have made this possible. The city-line investigations added some information concerning its geographical extension and the boundaries and contacts in Copenhagen. Hence a reference area and a reference section in Copenhagen are defined:

Lellinge Greensand. Emended.

Name: From the village Lellinge west of Køge. 
Type area: The eastern and central part of Sealand.

Type locality: Lellinge. Skovhus Vænge.

Reference area: The area between the South harbour and St. Jørgens sø in Copenhagen.

Reference section: Vestre Gasværk, the profile lithologically described by Rosenkrantz (1930 p. 381-384), the interval 5.95 to 10.17 metres below sea-level. For further descriptions and references see Gry (1935) and Sorgenfrei (1957).

Diagnostic features: Glauconitic limestones, sands and marls.

Boundaries and contacts: The Lellinge Greensand overlies the København Limestone and is overlain by Quaternary deposits. The boundaries are erosional unconformities. The upper and lower boundary-levels are mapped in figs. 35 and 39 .

Geographic distribution in the Copenhagen area: From the South harbour to the Sound.

Thickness: The maximum thickness exceeds 6 metres (Gry 1935), but cannot be estimated since all known occurrences are eroded. The greatest thickness recognized is approximately 4 metres.

Age: Middle Palaeocene, Lower Selandian, the Globorotalia angulata zone (Hansen 1968).

Correlations: The Lellinge Greensand may be correlated with parts of the Kerteminde Marl on Funen and the western part of Sealand. In Scania it may be correlated with the Tertiary deposits at Klagshamn and Ystad.

The Pre-Pleistocene surface. The Lellinge Greensand is the youngest Tertiary deposit in the Copenhagen area, and thus it is suggested that in early Tertiary times the area was uplifted and eroded. During the Pleistocene glaciations the area was influenced by glaciers and meltwater streams, which set their mark on the Pre-Pleistocene surface (figs. 35 and 36) and removed large parts of the Lellinge Greensand and parts of the København Limestone, especially to the west of the investigation area.

From west to east the Pre-Pleistocene surface of the Copenhagen region forms a gently dipping upland, traversed by some buried subglacial valleys which may coincide with fault zones or fracture zones in the limestone. Two such valleys are located under Hans Christian Andersen Boulevard and the Central Station-Tivoli area respectively (fig. 32).

Quaternary. In Copenhagen only deposits from the Weichselian glaciation are found. All traces of older Quaternary deposits were probably removed by this glaciation. As already mentioned, the Weichselian deposits usually comprise a lower and an upper moraine of clayey till and between these a sequence of glaciofluvial deposits. The thickness of the glacial deposits 


\begin{tabular}{|c|c|c|c|c|}
\hline & onostratigraphy & Lithostratigraphy & Lithology & $\begin{array}{l}\text { Thicknesses } \\
\text { (metres) }\end{array}$ \\
\hline \multirow{3}{*}{ 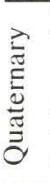 } & \multirow[t]{2}{*}{ Holocene } & & Earth fill & $1.5-10$ \\
\hline & & & Sands, silts, clays, gyttja and peat & few metres \\
\hline & \multicolumn{2}{|l|}{$\begin{array}{l}\text { Pleistocene } \\
\text { (Weichselian) }\end{array}$} & $\begin{array}{l}\text { Solifluction sands and clays } \\
\text { Clayey and sandy till/Glaciofluvial clay and sand }\end{array}$ & $\begin{array}{l}\text { few metres } \\
10-15\end{array}$ \\
\hline \multirow{3}{*}{ 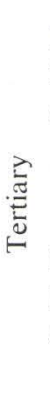 } & $\begin{array}{l}\text { Middle } \\
\text { Palaeocene } \\
\text { (Selandian) }\end{array}$ & $\begin{array}{l}\text { Lellinge } \\
\text { Greensand }\end{array}$ & $\begin{array}{l}\text { Glauconitic clay (marl) } \\
\text { Glauconitic sand } \\
\text { Glauconitic limestone } \\
\text { Conglomerate }\end{array}$ & $0-6$ \\
\hline & \multirow{2}{*}{$\begin{array}{l}\text { Lower } \\
\text { Palaeocene } \\
\text { (Danian) }\end{array}$} & $\begin{array}{l}\text { København } \\
\text { Limestone }\end{array}$ & $\begin{array}{l}\text { Calcarenites, regularly bedded, with flint beds } \\
\text { Calcarenites, bioturbated, with flint } \\
\text { Calcarenites, clayey, mainly regularly bedded, } \\
\text { with flint beds }\end{array}$ & $40-45$ \\
\hline & & $\begin{array}{l}\text { Bryozoan } \\
\text { Limestone unit }\end{array}$ & $\begin{array}{l}\text { Bryozoan limestones and calcilutites with flint } \\
\text { Calcilutites }\end{array}$ & $50-65$ \\
\hline$\dot{U}$ & Maastrichtian & White Chalk unit & Calcilutites (chalk) with nodular flint & approx. 500 \\
\hline
\end{tabular}

Fig. 60: Stratigraphy and lithology. 
ranges between 5 and 40 metres. In most places the thickness is about 10 to 15 metres. In parts of the town the upper moraine is missing. The lower moraine may contain reworked interglacial deposits. In the till it is quite common to find lumps of stiff Jurassic clay from Scania and of Lellinge Greensand and Danian limestones from the subjacent Pre-Pleistocene formations.

Late Weichselian fluvioglacial deposits seem to play no important role in this area, but solifluction deposits are to be found in many parts of the town, especially in the valley in which the lakes are situated.

Postglacial deposits must be widely distributed in the lowlying areas around the lakes and at the harbour (figs. 31 and 32), but they are not often found in the boreholes. This might be due to the fact that most of these areas are filled up with earth and mixed with the filling so that it is all converted to earth. The earth fill has a thickness of 2-3 metres in the old town and up to 10 metres in the old moats (fig. 33).

\section{Structural conditions}

One of the aims of the geological investigations for the city-line project was to detect possible inhomogeneities, especially faults and fracture zones. For this purpose some bio- and lithostratigraphical reference levels were mapped (figs. 39-43). The design of these maps was based on a model which again was based on the map fig. 38. According to this model the Maastrichtian and Danian limestones were gently folded and divided into blocks by faulting. The tectonic movements were thought to have had a modest vertical effect, leaving the limestone sequence practically horizontal. On the basis of the structural maps (figs. 39-43) random vertical sections as e.g. figs. 44 and 45 can be made. These sections may serve as an illustration of the modified structural model. According to this, the Chalk, the limestones of the Bryozoan Limestone unit, and the lowermost part of the København Limestone have been slightly folded along axes roughly parallel to the NW-SE direction of the Fennoscandian Border Zone. This folding has produced a maximum dip of approximately 1:200, i.e. the bedding is practically horizontal. The folding is demonstrated by a gentle anticline under the central part of the city and by shallow depressions/synclines under the North and South harbours. The limestones in the upper part of the København Limestone also undulate slightly, but this may be a result of the sedimentation itself, since the relief is smoothed upwards. The limestones are probably cut by some minor faults (A-E in figs. 40-45) with vertical displacements amounting to 5-6 metres. The vertical displacement seems to decrease upwards in the sequence, suggesting successive movements in the faultzones during the sedimentation of the København Limestone. The faults, B, C, D may not affect the upper 6-8 
metres of the København Limestone, but it is likely that faults A and E cut all of the Danian, thus indicating post-Danian movements. The very slight folding is late Danian in age. The faults are the upper branches of deep fault systems belonging to the Fennoscandian Border Zone, which forms the transition between the structurally elevated Scandinavian basement and the Danish Embayment.

\section{Areal geology}

The geological descriptions are followed by a description of five selected areas of the town. These descriptions are presumed to be of local interest only, and consequently they are not summarized. However, the text figures are explained in English. 


\section{Litteraturliste}

Ambt, C., Johnstrup, F. \& Steenbuch, C., 1888 a: Nogle Undersøgelser af Grundluften, Grundvandet og Jordbunden i Kjøbenhavn og Frederiksberg på Foranstaltning af Selskabet for Sundhedsplejen i Danmark. - Jacob Lunds Boghandel. København. 42 p.

- \& Schønheyder, C., 1888 b: Kalkens beliggenhed samt Vandreisningen ved Kjøbenhavn; samt Oversigt over de af Vandværket i 1886-87 udførte Undersøgelsesboringer i Københavns Omegn. - Københavns Magistrat. November 1888. 37 p.

Baartman, J.C. \& Christensen, O.B., 1975: Contributions to the interpretation of the Fennoscandian Border Zone. - Danm. geol. Unders. II. række, 102. 47 p.

Bahnson, H., 1973: Afsluttende oversigtsrapport vedrørende kvartærlagene og de yngre dannelser. - Danm. geol. Unders., Februar 1973.

- , Bang, I. \& Stenestad, E., 1969: Geologisk rapport nr. 2, vedrørende de geologiske forhold på strækningen Rådhuspladsen-Højbro Plads. (Ed.: E. Stenestad.) - Danm. geol. Unders., Juni 1969.

- , 1970: Geologisk rapport nr. 6, vedrørende de geologiske forhold på strækningen Højbro Plads-Kgs. Nytorv. (Ed.: E. Stenestad.) - August 1970.

- , 1971: Geologisk rapport nr. 8, vedrørende de geologiske forhold på strækningen Kgs.

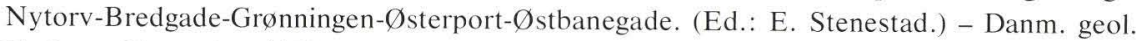
Unders., November 1971.

Bahnson, H., Bang, I., Jensen, H.H. \& Stenestad, E., 1972: Geologisk rapport nr. 9, vedrørende supplerende boringer for citybanen. (Ed.: E. Stenestad). - Danm. geol. Unders., Oktober 1972.

- \& Stenestad, E., 1970: Geologisk rapport nr. 5, vedrørende de geologiske forhold ved prøvefeltet i Reventlowsgade. (Ed.: E. Stenestad). - Danm. geol. Unders., Juni 1970.

Bang, I., 1969: Planktonic Foraminifera and Biostratigraphy of the Type Danian. (Ed.: P. Brönnimann \& H.H. Renz.) - Proc. 1st Internat. Conf. Plankt. Microfoss. Vol. 1, pp. 58-65, pl. 1-4, fig. 1-4. Leiden.

- , 1971: Planktonic Foraminifera of the Lowermost Danian. (Ed.: A. Farinacci.) - Proc. 2nd Internat. Conf. Plankt. Microfoss. Roma. 1970, pp. 17-19, pl. 1-6. Roma.

- \& Stenestad, E., 1970 a: Aktuelle undersøgelser af prækvartærlagene i København. (Foredragsreferat) - Nordisk geol. Vintermøde, Lyngby 1970.

- , 1970 b: Geologisk rapport nr. 3, vedrørende de geologiske forhold ved boringerne 121, $122 \mathrm{og}$ 123 i Svanemølleområdet. (Ed.: E. Stenestad.) - Danm. geol. Unders., Januar 1970.

Berggren, W.A., 1960: Biostratigraphy, planktonic Foraminifera and the Cretaceous-Tertiary boundary in Denmark and southern Sweden. - Int. Geol. Congr. XXI Sess., Sect. 5, pp. 181-192. Copenhagen.

- , 1962 a: Some Planktonic Foraminifera from the Maestrichtian and Type Danian Stages of Southern Scandinavia. - Stockh. Contr. Geol. IX, 1. pp. 1-106. pl. 1-14.

- , 1962 b: Stratigraphic and Taxonomic-Phylogenetic Studies of Upper Cretaceous and Paleogene Planktonic Foraminifera. - Stockh. Contr. Geol. IX, 2. p. 107-129. 
- , 1964: The Maestrichtian, Danian and Montian Stages and the Cretaceous-Tertiary boundary. - Stockh. Contr. Geol. XI, 5. pp. 103-176, 5 pl.

Berthelsen, O., 1962: Cheilostome Bryozoa in the Danian Deposits of East Denmark. - Danm. geol. Unders. II. række, 83.290 p., 28 pl.

Bonnesen, E.P., Bøggild, O.B. \& Ravn, J.P.L., 1913: Carlsbergfondets Dybdeboring i Grøndals Eng ved København 1894-1907 og dens videnskabelige Resultater. - Communs géol. Mus. Miner. Geol. Univ. Copenh. No. 3. 105 p. 8 pl.

Bromley, R.G., 1967: Some observations on burrows of thalassinidean Crustacea in chalk hardgrounds. - Q. Jl. geol. Soc. Lond., vol. 123, pp. 157-182.

- , Schulz, M.-G. \& Peake, N.B., 1975: Paramoudras: giant flints, long burrows and the early diagenesis of chalks. - Dan. Vid. Selsk. biol. Skr. 20,10. 31 p.

Brotzen, F., 1940: Flintrännans och Trindelrännans geologi. (Zusammenfassung in deutsch.) Sver. geol. Unders., Ser. C, No. 435. 33 p., 1 pl.

- 1945: De geologiska resultaten från borrningarna vid Höllviken. Del I. Kritan. - Sver. geol. Unders., Ser. C, No. 465, 64 p.

- , 1948: The Swedish Paleocene and its Foraminiferal Fauna. - Sver. geol. Unders., Ser. C, No. 493. $140 \mathrm{p} ., 19 \mathrm{pl}$.

- 1959: On Tylocidaris Species (Echinoidea) and the Stratigraphy of the Danian of Sweden. Sver. geol. Unders., Ser. C, No. 571. (Stor litteraturliste), 81 p., 3 pl.

Cheetham, A.H., 1971: Functional Morphology and Biofacies Distribution of Cheilostome Bryozoa in the Danian Stage (Paleocene) of Southern Scandinavia. - Smithson. Contr. Paleobiol., No. 6. 52 p., 17 pl.

Christensen, L. Fregerslev, S., Simonsen, A. \& Thiede, J., 1973: Sedimentology and depositional environment of Lower Danian fish clay from Stevns Klint, Denmark. - Bull. geol. Soc. Denmark, 22, pp. 193-212.

Christensen, W., 1959: Københavns vandforsyning i tiden efter 1859. - In: Festskrift i anledning af hundredåret for anlægget af stadens første vandværk i 1859. Københavns Vandforsynings Historie, pp. 123-249. Københavns Kommune

Desor, 1846: Sur le terrain danien, nouvel étage de la craie. - Bull. Soc. géol. Fr. Sér. 2, 4, pp. $179-182$.

Dinesen, A., Michelsen, O. \& Lieberkind, K., 1976: Kortlægning af paleocæne og eocæne aflejringer i Jylland og på Fyn. - In: Geologisk deponering i Danmark af højaktivt affald fra kernekraftværker. Rapport fra et arbejdsudvalg. Atomenergikommissionen, marts 1976. Bilag nr. 2, pp. 79-99. 6 pl.

Forchhammer, J.G., 1843 a: Om artesiske Brønde, og om Brøndboringen på Nyholm. - Dansk Ugeskrift. 2. række, vol. 2, 48-49, pp. 377-388. København.

_ , 1843 b: Geognostiske Iagttagelser over den sjellandske Kridtformation. - K. dansk Vidensk. Selsk. Forh. 1843. København. pp. 1-4.

- , 1849: Det nyere Kridt i Danmark. - Forh. skand. Naturf. 5te Möte, 1847, pp. 528-550. København.

_ , 1861: Om Leiringsforholdene og Sammensætningen af det nyere Kridt i Danmark. - Forh. skand. Naturf. 8de Möte, 1860, pp. 781-790. København.

Forchhammer, O., 1942: Specialundersøgelser vedrørende Kloaktunnelen i Øresund.-Stadsingeniørens direktorat. Beretning og regnskab 1941-42. København.

_ , 1949 a: København fra bispetid til borgertid. Byplanmæssig udvikling til 1840. - Stadsingeni$\emptyset$ rens direktorat 1947. 2. udg. 1949. København. 304 p.

_ , 1949 b: Boreundersøgelser i København og Øresund. (Foredragsref.) - Ingeniøren, no. 42, 1949. København.

Geoteknisk Institut, 1965: Øresund. Forarbejder for en fast forbindelse København-Malmö. - 
Udvalget vedrørende Øresundsforbindelserne. København.

- , 1969 a: Citybanen. Bundundersøgelser. Rådhuspladsen-Højbro Plads. - Geoteknisk Institut. Geoteknisk rapport no. 2. København.

- , 1969 b: Saltholm. Lufthavn. Geotekniske rapporter. Undersøgelser før 1969. - Geoteknisk Institut. København.

-, 1970 a: Svanemølletunnelen. - Geoteknisk Institut. Specialrapport no. 1. København.

- , 1970 b: Citybanen. Bundundersøgelser. Ingerslevsgade-Rådhuspladsen. - Geoteknisk Institut. Geoteknisk rapport no. 1. København.

- , 1970 c: Citybanen. Bundundersøgelser. Prøvefeltet Reventlowsgade. - Geoteknisk Institut. Specialrapport no. 2. København.

- , 1971 a: Citybanen. Bundundersøgelser. Højbro Plads-Kongens Nytorv. - Geoteknisk Institut. Geoteknisk rapport no. 3. København.

- , 1971 b: Citybanen. Ældre tunneler under Københavns Havn. - Geoteknisk Institut. Specialrapport no. 3. København.

- , 1972 a: Citybanen. Bundundersøgelser. Kongens Nytorv-Østbanegade. - Geoteknisk Institut. Geoteknisk rapport no. 4. København.

- , 1972 b: Citybanen. Prøvegrundvandssænkning Rådhuspladsen. - Geoteknisk Institut. Specialrapport no. 4. København.

- , 1973 a: Citybanen. Bundundersøgelser. Supplerende boringer. - Geoteknisk Institut. Geoteknisk rapport no. 5. København.

-, 1973 b: Citybanen. Kalkens hydrauliske egenskaber. - Geoteknisk Institut. Specialrapport no. 5. København.

Gry, H., 1935: Petrology of the Paleocene Sedimentary Rocks of Denmark. - Danm. geol. Unders. II. række, 61.171 p. 2 pl.

- \& Søndergaard, B., 1958: Flintforekomster i Danmark med særlig hensyntagen til flinttypernes petrografi. (Summary in English). - The Danish National Institute of Building Research and the Academy of Technical Sciences. Committee on Alkali Reactions in Concrete. Progress Report Series D, 2. 63 p.

Grönwall, K.A., 1897: Block of paleocän från Köpenhamn. - Meddr dansk geol. Foren. 1, 4. pp. $53-72$.

- 1899: Danmarks yngsta Krit- og äldsta tertiäraflagringar. - Forh. skand. Naturf. 15, möte. Stockholm 1898. pp. 223-228.

- , 1904: Forsteningsførende Blokke fra Langeland, Sydfyn og Ærø, samt Bemærkninger om de ældre Tertiærdannelser i det baltiske Område. - Danm. geol. Unders. II. række, 15. 62 p.

- , 1905: Nogle Bemærkninger om Lagfølgen ved Vestre Gasværk i København. - Meddr dansk geol. Foren. 11. pp. 119-121.

Hansen, H.J., 1968: On the biostratigraphical age of the Lower Selandian of Denmark. - Meddr dansk geol. Foren., 18, 3-4, pp. 277-284.

Hansen, J.M.: Upper Maastrichtian, Danian and Lower Selandian Dinoflagellates from a core-drilling in Copenhagen. - A preliminary report. - (In preparation).

Harder, P., 1922: Om Grænsen mellem Saltholmskalk og Lellinge Grønsand og nogle Bemærkninger om Inddelingen af Danmarks ældre Tertiær. (Résumé en français.) - Danm. geol. Unders. II. række, 38,108 p.

Heller, E., 1973: Kvartærtiden. - In: B. Rying \& A. Kennebo (Ed.): Danmark. Gyldendals Egnsbeskrivelse, 12: København og Københavns amt, pp. 89-97.

Högberg, E., 1971: Staining method for examination of siliceous, Cretaceous limestone II. Geol. Fören. Stockh. Förh. 93, pp. 707-713.

Håkansson, E., Bromley, R. \& Perch-Nielsen, K., 1974: Maastrichtian chalk of north-west Europe - a pelagic shelf sediment. - Spec. Publs. int. Ass. Sediment. 1974, 1. pp. 211-233. 
Johnstrup, F., 1872: Grønsandslagene i Danmark. - Tidsskr. for Landøkonomi. (Ed.: J.C. la Cour.) 4. række, VI, pp. 406-414. København.

_ , 1876: Om Grønsandet i Sjælland. - Vidensk. Meddr dansk naturh. Foren. 1876, pp. 1-32. København.

Kennedy, W.J. \& Juignet, P., 1974: Carbonate banks and slump beds in the Upper Cretaceous (Upper Turonian-Santonian) of Haute Normandie, France. - Sedimentology. 1974, 21, pp. $1-42$.

Kerrn-Jespersen, P., 1945: Kloakudløbsledningen under Øresund. - Ingeniøren, 1945, pp. A 173-A 179. København.

v. Koenen, A., 1885: Ueber eine Paläocäne Fauna von Kopenhagen. - Abh. K. Ges. Wiss. Göttingen, 32, 128 p.

Larsen, G., 1961: Kvantitativ petrografisk undersøgelse af nogle sjællandske Danienkalksten. (Summary in English.) - Danm. geol. Unders. IV. række, 4, 7. 25 p.

_, 1965: Geologiske forhold. - In: Geoteknisk Institut (1965): Øresund. pp. 16-20.

_ , 1966: Geologiske resultater af bundundersøgelserne i Øresund. - Meddr dansk geol. Foren. 16. pp. 260-265.

- , 1967: Geologi. In: Saltholm. Bundundersøgelser 1967. Geoteknisk rapport. - Geoteknisk Institut 1967 , pp. 8-12.

- , 1969: Geologisk rapport. In: Geoteknisk Institut (1969b): Saltholm. Bilag 1.

- , Christensen, O.B., Bang I. \& Buch, A., 1968: Øresund. Helsingør - Hälsingborg Linien. Geologisk rapport. (Summary in English). - Danm. geol. Unders. Rapport 1. 90 p.

Lomholt, A., 1960: Artesisk Brøndboring på Nyholm. - In: Det Kongelige Danske Videnskabernes Selskab 1742-1942. Samlinger til selskabets historie III, pp. 343-359.

Mangerud, J., Andersen, S. T., Berglund, E. \& Donner, J.J., 1974: Quaternary stratigraphy of Norden, a proposal for terminology and classification. - Boreas, 3, pp. 109-126.

Marcussen, I., 1973: Studies on flow till in Denmark. - Boreas, 2, pp. 213-231.

- , 1975: Distinguishing between lodgement till and flow till in Weichselian deposits. - Boreas, 4, pp. 113-123.

Mertz, E.L., Bang, I. \& Stenestad, E., 1969: Geologisk rapport no. 1, vedrørende de geologiske forhold på strækningen Ingerslevsgade-Rådhuspladsen. (Ed.: E. Stenestad.) - Danm. geol. Unders., September 1969.

Milthers, V., 1935: Nordøstsjællands Geologi. (2. udg.) - Danm. geol. Unders. V. række, 3. 192 p.

Mølgaard, P., 1974: Citybanens historie m.v. - DSB. Tekniske meddelelser fra baneafdelingen. 4. årg. no. 1, pp. 1-4. København.

Nathorst, A.G., 1887: Till frågan om de skånska dislokationernas ålder. - Geol. Fören. Stockh. Förh. 9, 2 pp. 74-130.

Nielsen, E.B., 1976: Petrographic study of Danian limestone from eastern Denmark (Core Copenhagen TUBA 13.) - Danm. geol. Unders. II. række, 106. 26 p.

Nielsen, K. Brünnich, 1910: Om det i Københavns Havn ved Knippelsbro fundne Yngste Danien. - Meddr. dansk geol. Foren. 3, 16. pp. 463-474.

_ , 1926: Kalken på Saltholm. (Summary in English.) - Danm. geol. Unders. IV. række, 1, 20. 23 p.

Ramsing, H.U., 1940: Københavns historie og topografi i middelalderen. - Munksgaards forlag. København, 1, 309 p.

Rasmussen, H.W., 1971: Echinoid and crustacean burrows and their diagenetic significance in the maastrichtian-danian of Stevns Klint, Denmark. - Lethaia, 4, pp. 191-216.

Rosenkjær, H.N., 1896: Fra Frihavnens Bund. - Naturen og Mennesket. 15, pp. 259-284. Aarhus. 
Rosenkrantz, A., 1920 a: Craniakalk fra Kjøbenhavns Sydhavn. (Résumé en français.) - Danm. geol. Unders. II. række, 36, $79 \mathrm{p}$.

- , 1920 b: En ny københavnsk Lokalitet for forsteningsførende Paleocæn. - Meddr dansk geol. Foren. 5, 20. 10 p..

- , 1923: En Trionyx fra Craniakalkblokke i København. - Meddr dansk geol. Foren. 6, 19. pp. $1-14$.

— , 1924 a: De københavnske Grønsandslag og deres Placering i den danske Lagrække. Med et Skema over det danske Paleocæen. - Meddr dansk geol. Foren. 6, 23. pp. 1-39.

- , 1924 b: Nye Iagttagelser over Cerithiumkalken i Stevns Klint med Bemærkninger om Grænsen mellem Kridt og Tertiær. (Foredragsreferat). - Meddr dansk geol. Foren. 6, pp. $28-31$.

- , 1925: Undergrundens tektoniske Forhold i København og nærmeste Omegn. - Meddr dansk geol. Foren. 6, 26. 18 p.

- , 1930: Den paleocæne Lagserie ved Vestre Gasværk. - Meddr dansk geol. Foren. 7, 5. pp. 371-390.

- , 1931: Jordskorpebevægelser i Yngre Danien-Tid inden for Øresundsområdet. (Foredragsreferat). - Meddr dansk geol. Foren. 8. pp. 138-139.

- , 1934: Notits vedrørende en Brudlinie i det sydøstlige Københavns Undergrund. - Meddr dansk geol. Foren. 8, 4. pp. 407-410

- , 1935: Ekskursion til Saltholm. - Meddr dansk geol. Foren. 8, pp. 457-458.

- , 1937: Bemærkninger om det østsjællandske Daniens Stratigrafi og Tektonik. - Meddr dansk geol. Foren. 9. pp. 199-212.

- , 1941: Ekskursion til Tunnelanlægget Svanemøllen-Middelgrund. - Meddr dansk geol. Foren. 10. p. 64.

- , 1955: Københavns Klippegrund og Trafikproblemer. - Salmonsens Leksikon Tidsskrift. p. $653 \mathrm{ff}$.

- , 1966: Die Senon/Dan-Grenze in Dänemark. - Ber. dt. geol. Wiss. A, Geol. Paläont. II, pp. $721-727$.

- \& Rasmussen, H.W., 1960: South-Eastern Sjælland and Mön, Denmark. - XXI Int. Geol. Congr. Guidebook A 42 \& C 37, pt. 1. Copenhagen.

Rørdam, K., 1897: Kridtformationen i Sjælland i Terrænet mellem København og Køge, og på Saltholm. (Résumé en français.) - Danm. geol. Unders. II. række, 6. 152 p.

- , 1899: Kortbladene København og Roskilde. (Résumé en français.) - Danm. geol. Unders. I. række, 6. 107 p.

Sorgenfrei, Th., 1957: Lexique stratigraphique international, 1, 2 d, Danemark. 44 p.

- , 1959: Dybgrundens geologi. - In: Trap Danmark, vol. I, 2. Storkøbenhavn I, pp. 354-359.

- \& Berthelsen, O., 1954: Geologi og Vandboring. (Abstract in English). - Danm. geol. Unders. III. række, 31. $106 \mathrm{p}$.

Steinich, G., 1967: Sedimentstrukturen der Rügener Schreibkreide. - Geologie, 16, 5. pp. 570-583.

Stenestad, E., 1969: Rapport no. 1 vedrørende Core no. 1 fra $ø v$ re kridt i Dansk Nordsø D-1. Danm. geol. Unders., Januar 1969. - Upubliceret.

- , 1970: Geologisk rapport nr. 4: Fotografier af bjergarter fra citybaneboringerne. - Danm. geol. Unders. 1970. Intern rapport.

- , 1971 a: Geologisk rapport nr. 7, vedrørende tunnelerne under Københavns inderhavn og sydhavn. - Danm. geol. Unders. Juli 1971.

- , 1971 b: Øvre kridt i Rønde nr. 1. (Summary in English). - In: L. Banke Rasmussen(ed.): Dybdeboringen Rønde nr. 1 på Djursland. - Danm. geol. Unders. III. række, 39. pp. 53-60. 
- , 1972: Træk af det danske bassins udvikling i Øvre Kridt. - Dansk geol. Foren. Årsskrift 1971. pp. 63-69.

- , 1973 a: Sammenfattende rapport vedrørende de geologiske forundersøgelser for citybanen i København. - Danm. geol. Unders. Marts 1973.

- , 1973 b: Den prækvartære undergrund. - In: B. Rying \& A. Kennebo (Ed.): Danmark. Gyldendals Egnsbeskrivelse. 12: København og Københavns amt. pp. 83-89.

-, 1973 c: Øvre kridt i Nøvling nr. 1. (Summary in English). - In: L.B. Rasmussen (Ed.): Dybdeboringen Nøvling nr. 1 i Midtjylland. - Danm. geol Unders. III. række, 40, pp. 86-99.

- , 1974: Geologiske resultater af citybaneundersøgelsen. - DSB. Tekniske meddelelser fra baneafdelingen. 4. årg., nr. 1, pp. 9-18.

- , 1975: Geologisk rapport over de i 1974 udførte boringer på og ved Saltholm. - Danm. geol. Unders. Intern rapport.

Troelsen, J.C., 1957: Some planktonic foraminifera of the type Danian and their stratigraphic importance. - Bull. U.S. natn. Mus. 215, pp. 125-132.

Voigt, E., 1929: Die Lithogenese der Flach- und Tiefwassersedimente des jüngeren Oberkreidemeeres. - Jb. halle. Verb. 8. 165 p.

- \& Häntzschel, W. 1956: Die grauen Bänder in der Schreibkreide Nordwestdeutschlands und ihre Deutung als Lebensspuren. - Mitt. geol. St. Inst. Ham., 25. pp. 104-122.

Wolfe, M.J., 1968: Lithification of a carbonate mud: Senonian chalk in Northern Ireland. Sedim. Geol. 2. pp. 263-290.

Ødum, H., 1971: Danium og Maastrichtium på Skanörhalvön. - Sver. geol. Unders. Ser. C, no. 659. $13 \mathrm{p}$.

Ørsted, H.C., 1832: Om det Kgl. Videnskabernes Selskabs Foranstaltninger til at skaffe Kjøbenhavn artesiske Brønde. - Dansk Ugeskrift (Ed.: J.F. Schouw). Bd. 1. pp. 199-204. København.

- , 1842: Om Varmheden paa Bunden af det artesiske Borehul på Nyholm, i en Dybde af 518 Fod. - Oversigt over K. Dansk. Vidensk. Selsk. Forh. 1842. no. 5. pp. 69-70

Tabel 1. Koteliste. (Fortegnelse over boringer i Øst-København).

Kotelisten indeholder et udvalg af boringer, omfattende næsten alle prækvartærboringer samt nogle boringer, som efter deres beliggenhed og dybde kunne ventes at have truffet prækvartære

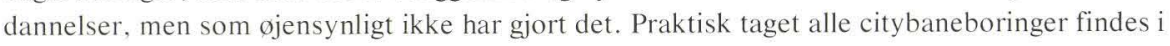
listen.

Boringerne ligger alle på Geodætisk Instituts atlasblad A 3030 (D.G.U. atbl. nr. 201) og de er opført i listen efter deres D.G.U. arkivnummer.

Terrankoterne er nivelleret (A), oplyst $\mathrm{i}$ indberettede data (B) eller aflæst på målebordsblad (C). A-C angiver således en aftagende grad af sikkerhed i de angivne koter. Der er kun medtaget en decimal i dybdeangivelserne.

Top af kvartaer angiver fyldlagets undergrænse.

Selandien betegner glaukonitiske aflejringer (Lellinge Grønsand) fra mellem paleocæn.

Kalk kan i dette område enten tilhøre Lellinge Grønsand (selandien) eller København Kalk (danien). Top af København Kalk vil i alle tilfælde findes højst ca. 1 m under kalkoverfladen.

$K K$ og $B K$ betegner aflejringer tilhørende henholdsvis København Kalken og bryozokalkenheden (se fig. 34).

Slutkote er navnlig anført, for at man kan bedømme, hvor sikker tilstedeværelsen af den nederst angivne formationelle enhed er. Mange boringer er standset i toppen af kalken.

I bemarkninger anføres omtrentlige lokalitetsbetegnelser, eller, for citybaneboringer, deres TUBA-nummer. Havnevæsenets boringer er mærket $K H V$.

Bemærk, at boringerne på lokalitetskortet (fig. 1) er forsynet med deres D.G.U.-nummer. 


\begin{tabular}{|c|c|c|c|c|c|c|c|c|c|c|c|}
\hline \multirow{3}{*}{\multicolumn{2}{|c|}{$\begin{array}{l}\text { D.G.U. } \\
\text { Borearkiv } \\
\text { nr. pa } \\
\text { atibl.nr. } \\
201\end{array}$}} & \multirow{2}{*}{\multicolumn{2}{|c|}{$\begin{array}{c}\text { Terrenkote } \\
m\end{array}$}} & \multicolumn{6}{|c|}{ Koter i m til top af: } & \multirow{3}{*}{ Siutkote } & \multirow[t]{3}{*}{ Bemærkninger } \\
\hline & & & & \multirow[t]{2}{*}{ Kvartær } & \multirow[t]{2}{*}{ Selandien } & \multirow[t]{2}{*}{ 'Ka lk' } & \multicolumn{2}{|c|}{ Danien } & \multirow{2}{*}{$\begin{array}{c}\text { Maastrichtien } \\
\text { kridt }\end{array}$} & & \\
\hline & & $\begin{array}{l}\text { Niv. } \\
\text { opl: } \\
\text { Afi: }\end{array}$ & $\begin{array}{l}\text { A } \\
\text { B } \\
\text { C }\end{array}$ & & & & KK & $B K$ & & & \\
\hline & 13 & 77,5 & A & 10,5 & & $-9,1$ & & & & $-12,8$ & Lammefæl 1ed \\
\hline & 17 & 7,6 & B & $1,6 ?$ & $-10,0$ & & $-10,3$ & & & $-19,3$ & Sydhavnstunnelen \\
\hline & $19 a$ & 3,1 & B & 3,1 & & & $-4,4$ & & & $-5,3$ & Ostre Gasvark \\
\hline & 23 & 5,9 & A & 5,8 & & $-10,5$ & & & & $-13,4$ & Norrefalled \\
\hline & 26 & 13,2 & B & 13,2 & & $-15,7$ & & & & $-20,7$ & Lyngbyvej \\
\hline & 30 & $0.2,0$ & c & $-0,7$ & & $-14,5$ & & & & $-18,0$ & Nordisk Fjerfabrik \\
\hline & 34 & c. 2,5 & c & 0,6 & & $-8,5$ & & & & $-33,0$ & Strandboulevarden \\
\hline & $71 \mathrm{~b}$ & c. 2,0 & c & $-2,4 ?$ & & & $-14,0$ & & & $-19,1$ & Lynetten \\
\hline & 716 & $c .2,0$ & c & $-2,5 ?$ & & & $-16,8$ & & & $-30,8$ & Lynetten \\
\hline & 89 & 4,1 & B & 4,1 & $-5,8$ & & $-6,3$ & & & $-8,2 ?$ & Vodroffgards Molle \\
\hline & 90 & 1,6 & B & $-1,3$ & & & $-73,8$ & & $-109,8$ & $-187,2$ & Nyholmboringen \\
\hline & 93 & 5,6 & 8 & $-0,6$ & & $-9,7$ & & & & $-25,4$ & Rosenborg Brondanst. \\
\hline & 95 & 15,7 & B & 15,7 & & $-11,0$ & & & & $-13,2$ & Jagtvejen \\
\hline & 96 & 4,4 & B & $4,4 ?$ & & $-10,7$ & & & & $-15,7$ & Helsingorsgade \\
\hline & 97 & 2,8 & B & $2,8 ?$ & & $-10,0$ & & & & $-11,9$ & Snaregade \\
\hline & 101 & 7,7 & A & 7,7 & & $-7,7$ & & & & $-10,9$ & Lersoen \\
\hline & 1150 & 0,0 & B & $-5,6$ & & $-13,9 ?$ & & & & $-14,0$ & orlogsverftet \\
\hline & 1150 & 0,0 & B & $-6,3$ & & $-11,5 ?$ & & & & $-12,1$ & Orlogsværftet \\
\hline & $115 \mathrm{e}$ & 0,0 & B & $-6,2$ & & $-10,4 ?$ & & & & $-11,8$ & orlogsvarftet \\
\hline & $115 \mathrm{~g}$ & 0,0 & B & $-6,3$ & & $-9,3 ?$ & & & & $-9,7$ & orlogsverftet \\
\hline & $115 h$ & 0,0 & B & $-5,9$ & & $-13,8 ?$ & & & & $-14,1$ & orlogsværftet \\
\hline & $115 i$ & 0,0 & B & $-5,5$ & & $-10,7 ?$ & & & & $-12,2$ & Orlogsværftet \\
\hline & 117 & 1,6 & B & & $-6,0$ & & $-10,2$ & & & $-10,2$ & Vestre Gasverk \\
\hline & 123 & 1,9 & B & $-4,1$ & & $-18,4$ & & & & $-20,7$ & Nordisk Fjerfabrik \\
\hline & $137 \mathrm{~A}$ & & & & & & & & & $-13,3$ & Sundkrogen bor. A \\
\hline & $137 \mathrm{~B}$ & & & & $-10,8$ & & & & & $-14,5$ & Sundkrogen bor. B \\
\hline & 1371 & & & & $-10, ?$ & & & & & $-16,1$ & -" - (Rosenkrantz) \\
\hline & 1371 & & & & c. $-10,5$ & & & & & $-16,1$ & -" - (Harder) \\
\hline & 13711 & & & & $-11,5$ & & $-14,8$ & & & $-14,9$ & -" - (Rosenkrantz) \\
\hline & $137 \mathrm{II}$ & & & & c. $-12,0$ & & $-14,8$ & & & $-14,8$ & -" - (Harder) \\
\hline & 152 & 1,3 & $c$ & $-0,3$ & & & $-9,3$ & & & $-38,8$ & Uplandsgade \\
\hline & 187 & c. 1,5 & $\mathrm{c}$ & $-0,4$ & & $-9,8$ & & & & $-19,8$ & Prags Boulevard \\
\hline & 188 & c. 1,5 & c & $1,5 ?$ & & $-7,6$ & & & & $-22,0$ & Holmb lads gade \\
\hline & $189 a$ & c. 7,5 & c & 7,2 & & $-8,2$ & & & & $-71,9$ & Hans Knudsens Plads \\
\hline & $195 a$ & $c .2,0$ & c & $-4,3$ & & $-10,6$ & & & & $-75,7$ & Is lands Brygge \\
\hline & $195 b$ & $c .2,0$ & $c$ & 1,0 & & & $-11,7$ & & & $-23,0$ & [stands Brygge \\
\hline & 196 & c. 8,0 & $c$ & $8,0 ?$ & & $-10,8 ?$ & & & & $-86,2$ & Larsbjørnstræde \\
\hline & 197 & 13,0 & A & 12,8 & & $-9,3$ & & & & $-11,8$ & Fælledparken \\
\hline & 199 & 7,7 & A & 7,2 & & $-7,9$ & & & & $-13,1$ & Vognmandsmarken \\
\hline & 217 & 6,0 & B & 3,9 & $-7,7 ?$ & $-9,4$ & & & & $-9,7$ & Frihedsstotten \\
\hline & 236 & 1,5 & B & 0,5 & & $-11,7$ & & & & $-17,1$ & Telemarksgade \\
\hline & 237 & c. 1,5 & c & 0,4 & & $-13,4$ & & & & $-32,5$ & Ose 1sgade \\
\hline & $239 b$ & c. 13,5 & c & 13,5 & & $-30,4$ & & & & $-68,7$ & Lyngbyvej \\
\hline & $239 c$ & c. 13,5 & $c$ & 13,5 & & & $-26,1$ & & & $-91,5$ & Lyngbyvej \\
\hline & $240 c$ & c. 13,0 & $c$ & 13,0 & & $-16,5$ & & & & $-41,3$ & Lyngbyvej \\
\hline & 243 & $c .11,8$ & B & 11,8 & & & $-8,3$ & & & $-103,3$ & Drejogade \\
\hline & $255 b$ & c. 3,0 & c & 0,8 & & & $-7,5$ & & & $-27,0$ & Viborggade \\
\hline & $273 c$ & c. 5,5 & $c$ & & & $-10,9$ & & & & $-10,9$ & Rádhuspladsen \\
\hline s & S $282-B$ & 0,0 & B & $-8,5$ & & $-12,6$ & & & & $-12,6$ & Svanemollebugten \\
\hline s & $5282-I$ & 0,0 & B & $-2,8$ & $-70,5$ & & & & & $-11,4$ & Svanemol lebugten \\
\hline s & S 282-IVa & 0,0 & B & $-13,0$ & & & & & & $-18,9$ & Svanemollebugten \\
\hline s & $5282-V$ & 0,0 & B & $-11,7$ & & & & & & $-21,1$ & $"$ \\
\hline s & $282-V I$ & 0,0 & B & $-9,4$ & & & & & & $-13,0$ & $"$ \\
\hline s & $5282-V I I$ & 0,0 & B & $-12,3$ & & $-19,2$ & & & & $-19,9$ & $"$ \\
\hline G & $=282-1$ & 0,0 & B & $-12,8$ & & $-17,7$ & & & & $-17,9$ & $"$ \\
\hline
\end{tabular}

D. G. U. III. rk. nr. 45 


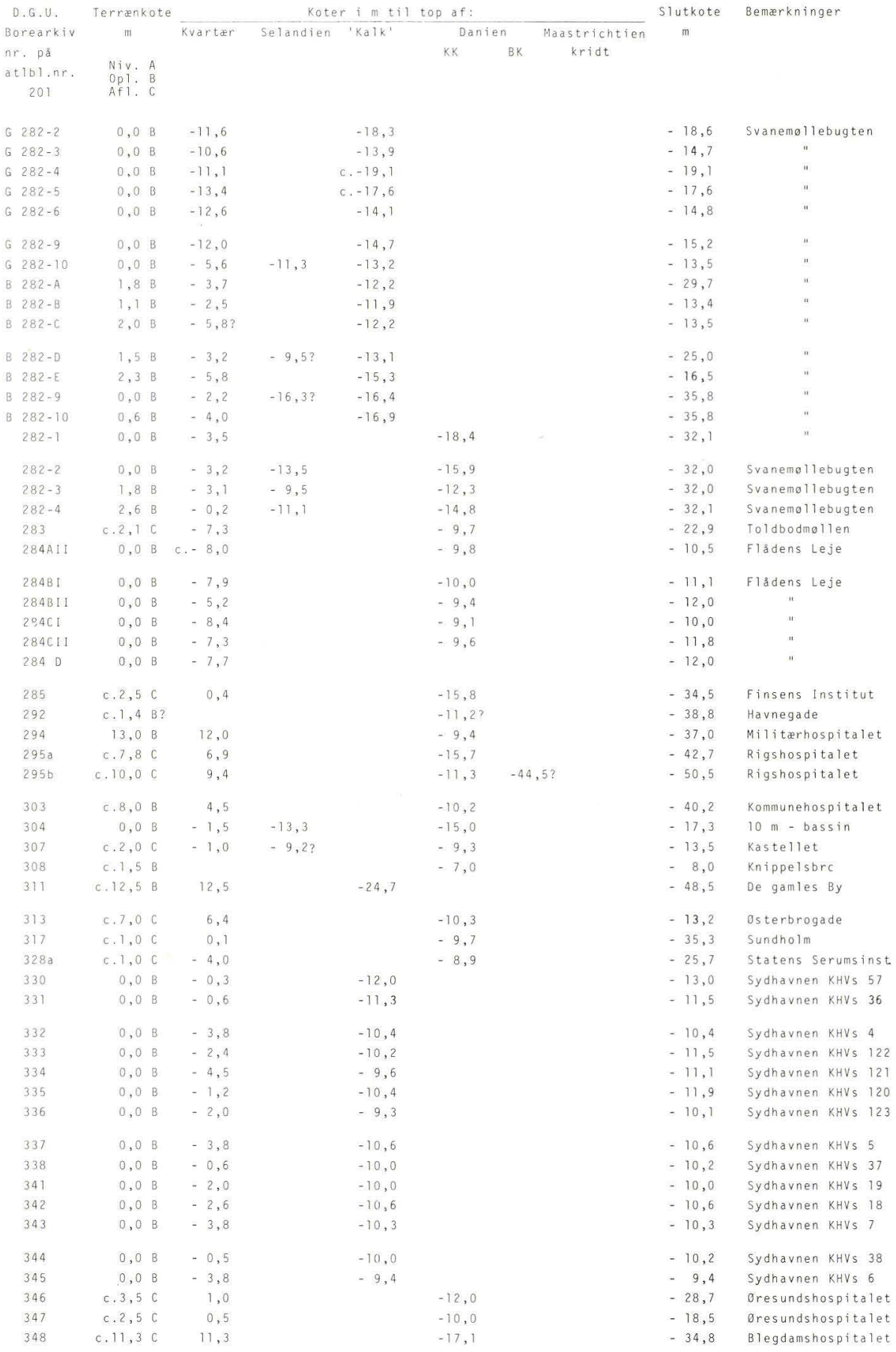




\begin{tabular}{|c|c|c|c|c|c|c|c|c|c|c|}
\hline D.G.U. & Terrænk & kote & & Kote & $r$ i m til & 1 top af: & & & Slutkote & Bemærkninger \\
\hline Borearkiv & in & & Kvartær & Selandien & 'Kalk' & & nien & Maastrichtien & $\mathrm{m}$ & \\
\hline $\begin{array}{l}n r \cdot p \AA \\
\text { at } 101 . n r . \\
201\end{array}$ & $\begin{array}{l}\text { Niv. } \\
\text { Op } 1 . \\
\text { Af } 1 .\end{array}$ & $\begin{array}{l}A \\
B \\
C\end{array}$ & & & & $K K$ & $B K$ & $k r i d t$ & & \\
\hline $353 a$ & 2,3 & B & $-1,2$ & & & $-13,2$ & & & $-15,3$ & Langebro KHV 261 \\
\hline $353 b$ & 2,6 & B & $-1,3$ & & & $-12,2 ?$ & & & $-12,6$ & Langebro KHV 262 \\
\hline $353 . c$ & 2,5 & B & $-1,3$ & & & $-13,5$ & & & $-14,0$ & Langebro KHV 263 \\
\hline $353 d$ & 2,9 & B & $-3,1$ & & & c. $-11,6$ & & & $-11, ?$ & Langebro KHV 264 \\
\hline $353 \mathrm{e}$ & 2,2 & B & $-2,4$ & & & $-11,5$ & & & $-11,6$ & Langebro \\
\hline $353 \mathrm{f}$ & 2,3 & B & $-3,1$ & & & & & & $-11,1$ & Langebro \\
\hline $409 a$ & 2,8 & A & $2,8 ?$ & & & $-7,9$ & & & $-9,3$ & Ostervoldgade \\
\hline 4090 & 3,3 & A & $3,3 ?$ & & & $-8,6 ?$ & & & $-9,4$ & Ostervoldgade \\
\hline $417 a$ & $c .5,0$ & c & 1,7 & $-8,3$ & & $-11,3$ & & & $-12,1$ & Frihedsstotten \\
\hline $417 b$ & 3,3 & B & 2,7 & $-7,9$ & & & & & $-7,9$ & Frihedsstotten \\
\hline $418 a$ & c. 9,0 & c & 5,8 & & & $-10,5$ & & & $-30,1$ & Norregade \\
\hline $418 b$ & $c .9,0$ & c & 6,3 & & & $-10,3$ & & & $-31,0$ & Norregade \\
\hline 422 & $0,0 ?$ & & $-7,0$ & $-11,5$ & & $-15,2$ & & & $-15,2$ & B \& w tordok \\
\hline $482 a$ & 0,0 & B & $-5,4$ & & & & & & $-8,2$ & Asiatisk Plads \\
\hline $482 b$ & 0,0 & B & $-6,7$ & & & & & & $-9,0$ & Asiatisk Plads \\
\hline $488 a$ & c. 2,3 & c & $-0,7$ & & $-14,2$ & & & & $-14,8$ & V. Boulevard \\
\hline $491 \mathrm{c}$ & 1,7 & c & $-1,6$ & & & c. $-7,0$ & & & $-8,6$ & Larsens Plads \\
\hline $495 c$ & 2,5 & c & $-3,9$ & & & & & & $-10,4$ & Sundmolen \\
\hline $496 a$ & 2,2 & $c$ & $-2,9$ & $-16,0$ & & & & & $-16,8$ & Refshaleoen \\
\hline $496 b$ & 2,2 & $c$ & $-2,4$ & $-14,9$ & & & & & $-16,7$ & Refshaleoen \\
\hline $531 \mathrm{a}$ & c. 6,0 & c & 3,9 & $-7,5 ?$ & & $-10,5$ & & & $-10,9$ & Hamerichsgade \\
\hline $531 b$ & 6,6 & A & 3,7 & $-8,0$ & & $-10,9$ & & & $-11,4$ & $"$ \\
\hline $531 d$ & 6,2 & A & 4,2 & $-7,5$ & & $-10,4$ & & & $-10,8$ & $"$ \\
\hline $531 \mathrm{a}$ & $(0,2)$ & & 0,2 & $-7,6$ & & & & & $-10,3$ & $"$ \\
\hline $531 r$ & $(0,2)$ & & 0,2 & $-7,8$ & & & & & $-10,2$ & $"$ \\
\hline 5315 & $(0,2)$ & & 0,2 & $-7,7$ & & & & & $-8,2$ & Hammerichsgade \\
\hline 5314 & $(0,2)$ & A & 0,2 & $-7,7$ & & & & & $-8,3$ & Hammerichsgade \\
\hline 679 & 2,3 & A & 0,4 & $-9,8$ & & & & & $-11,1$ & Is lands Brygge \\
\hline 680 & 2,4 & A & $-0,8$ & $-8,2$ & & & & & $-11,6$ & Is lands Brygge \\
\hline 681 & 2,3 & A & $-0,3$ & $-8,6$ & & & & & $-11,5$ & Is lands Brygge \\
\hline 682 & 2,6 & A & $-0,7$ & $-10,7$ & & & & & $-11,7$ & Islands Brygge \\
\hline 683 & 2,7 & A & $-1,6$ & $-10,8$ & & & & & $-10,9$ & Is lands Brygge \\
\hline 738 & 2,8 & A & $-0,6$ & & & & & & $-7,1$ & Sommerstedgade \\
\hline 746 & 1,8 & A & $-1,2$ & & & & & & - $\quad 9,0$ & Langeliniepavil. \\
\hline 765 & 2,3 & A & $-8,0$ & & $-12,3 ?$ & & & & $-12,6$ & Lüdersvej \\
\hline 766 & 2,5 & A & $-7,5$ & & & & & & $-12,8$ & Lüdersvej \\
\hline 767 & 2,0 & A & $-6,7$ & $-11,1$ & & $-12,6$ & & & $-12,7$ & Lüdersvej \\
\hline 768 & 2,1 & A & $-6,4$ & $-10,4$ & $-12,2$ & & & & $-12,3$ & Lüdersvej \\
\hline 785 & 2,5 & A & $-9,7$ & & & $-72,1$ & & & $-12,5$ & Lüdersvej \\
\hline 838 & 3,9 & A & 2,0 & & & & & & $-10,6$ & Radhuspladsen \\
\hline 840 & 0,0 & B & $-3,6$ & & $-11,1$ & & & & $-11,4$ & Gronlandske Handel \\
\hline 841 & 0,0 & B & $-3,9$ & & & & & & $-10,8$ & Gronlandske Hande 1 \\
\hline 842 & 0,0 & B & $-3,6$ & & & $-11,2$ & & & $-11,3$ & Gronlandske Handel \\
\hline 845 & 3,5 & A & $-1,0$ & & & & & & $-8,1$ & \\
\hline 860 & 2,4 & A & $-2,6$ & & $-9,6$ & & & & $-9,6$ & Hambroesgade \\
\hline 874 & c. 2,0 & c & 0,0 & & & $-9,5$ & $-58,0 ?$ & & $-87,5$ & Fisketorvet \\
\hline 877 & c. 13,0 & c & 12,5 & & & $-16,2$ & $-65,0 ?$ & & $-100,0$ & Lyngbyvej \\
\hline 896 & 2,0 & A & $-4,3$ & & & $-8,1$ & & & $-8,5$ & Strandgade \\
\hline 897 & 2.1 & A & $-0,6$ & & & $-8,6$ & & & $-8,9$ & Strandgade \\
\hline 920 & 1,6 & A & $-2,2$ & & & $-18,5 ?$ & & & $-20,0$ & Refshaleoen \\
\hline 921 & 1,9 & A & $-1,7$ & $-14,2$ & & $-16,0$ & & & $-17,2$ & Refshalegen \\
\hline 961 & 2,5 & A & $-1,1$ & & & & & & $-7,5$ & Ostbanegade \\
\hline 982 & 2,8 & A & $-1,6$ & & & & & & $-6,4$ & Middel fartgade \\
\hline 1027 & 2,5 & A & 1,5 & & $-5,5$ & & & & $-6,0$ & Sct. Annæ Plads \\
\hline 1039 & 1,7 & A & $-0,9$ & & $-6,8$ & & & & $-6,9$ & Torvegade \\
\hline
\end{tabular}




\begin{tabular}{|c|c|c|c|c|c|c|c|c|c|c|}
\hline \multirow{3}{*}{$\begin{array}{l}\text { D.G.U. } \\
\text { Borearkiv } \\
n r . p a \\
\text { at } 1 \mathrm{bl} \cdot n r . \\
201\end{array}$} & \multirow{2}{*}{\multicolumn{2}{|c|}{$\begin{array}{c}\text { Terrankote } \\
m\end{array}$}} & \multicolumn{6}{|c|}{ Koter i m til top af: } & \multirow{2}{*}{$\begin{array}{l}\text { Slutkote } \\
m\end{array}$} & \multirow[t]{3}{*}{ Bemarkninger } \\
\hline & & & Kvartær & Selandien & 'Kalk' & Dan & & Mastrichtien & & \\
\hline & $\begin{array}{l}\text { Niv. } \\
\text { Opl. } \\
\text { Afl. }\end{array}$ & $\begin{array}{l}A \\
B \\
C\end{array}$ & & & & KK & $B K$ & kridt & & \\
\hline 1040 & 1,8 & A & $-5,0$ & & $-6,2$ & & & & $-6,3$ & Torvegade \\
\hline 1042 & 1,8 & A & 0,9 & & $-6,7$ & & & & - $\quad 6,9$ & $"$ \\
\hline 1043 & 1,9 & A & $-2,8$ & & $-7,6 ?$ & & & & $-7,6$ & $"$ \\
\hline 1044 & 2,2 & A & $-4,7$ & & $-7,2$ & & & & $-7,3$ & $"$ \\
\hline 1045 & 1,4 & A & $-0,8$ & & $-7,3$ & & & & $-7,4$ & " \\
\hline 1048 & 2,2 & A & & & $-7,4$ & & & & $-7,9$ & Christians Brygge \\
\hline 1049 & 1,9 & A & $-3,8$ & & & & & & $-7,6$ & Christians Brygge \\
\hline 1050 & 2,2 & A & $-3,8$ & & $-8,7$ & & & & $-9,1$ & Christians Brygge \\
\hline 1060 & 1,2 & A & $-2,2$ & & & & & & $-9,9$ & Gron 1. Handels Pl. \\
\hline 1061 & 1,5 & A & $-1,7$ & & & & & & $-11,5$ & Gron 1. Handels P1. \\
\hline 1062 & 1,9 & A & $-3,5$ & & $-12,5$ & & & & $-12,7$ & Gronl. Handels PI. \\
\hline 1108 & 3,3 & A & $-1,0$ & & $-10,6$ & & & & $-11,3$ & Ostergade \\
\hline 1109 & 3,7 & A & 0,6 & & $-7,7 ?$ & & & & $=8,3$ & Ostergade \\
\hline 1119 & $(c, 2,9$ & c) & $-3,3$ & & & & & & $-8,7$ & Aarhusgade \\
\hline 1125 & 3,3 & A & $-1,2$ & & & & & & $-7,7$ & Solvgade \\
\hline 1172 & 1,6 & A & $-4,9$ & & & $-15,1$ & & & $-17,2$ & Refshaleoen \\
\hline 1186 & 3,4 & A & $-1,9$ & & & & & & $-9,8$ & Islands Brygge \\
\hline 1220 & 2,2 & A & $-2,5$ & & $-12,0 ?$ & & & & $-12,0$ & Refshaleven \\
\hline 1296 & 2,5 & A & c. 0,0 & $-5,9$ & & $-8,7 ?$ & & & $-8,7$ & 5ke lbækgade \\
\hline 1297 & 2,5 & A & $-0,5$ & $-5,5$ & & $-8,5 ?$ & & & $-8,4$ & Ske lbækgade \\
\hline 1298 & 2,5 & A & $-2,0$ & $-5,5$ & & & & & $-7,8$ & Skelbækgade \\
\hline 1299 & 2,5 & A & 0,0 & $-5,4$ & & & & & $-8,1$ & Ske 1 bækgade \\
\hline 1340 & 0,0 & B & $-6,8 ?$ & & & & & & $-8,2$ & Gron 1. Hande 15 P1. \\
\hline 1341 & 0,0 & B & $-7,7$ & & & $-9,3$ & & & $-9,8$ & Gronl. Handels PI. \\
\hline 1342 & 0,0 & B & $-5,5$ & & & $-10,0 ?$ & & & $-10,2$ & Gronl. Handels PI. \\
\hline 1343 & 1,6 & A & $-5,0$ & & & $-10,3$ & & & $-10,4$ & Gronl. Handels PI. \\
\hline 1360 & 2,1 & A & $-2,3$ & & & & & & $-7,7$ & Fiskerihavnsgade \\
\hline 1364 & c. 1,3 & c & 0,6 & & & & & & $-9,2$ & Laplandsgade \\
\hline 1389 & 7,7 & A & 6,2 & & $-9,2$ & & & & $-9,8$ & Blegdamsvej \\
\hline 1397 & 2,1 & A & $-5,6$ & & & & & & $-9,5$ & Christians Brygge \\
\hline 1399 & 2,2 & A & $-5,1$ & & & & & & $-10,0$ & Christians Brygge \\
\hline 1417 & 3,2 & A & 1,0 & & & & & & $-4,8$ & Dannebrogsgade \\
\hline 1418 & 3,0 & A & 1,0 & $-4,8$ & & $-5,0 ?$ & & & $-4,9$ & Bymuseet \\
\hline 1419 & 2,8 & A & 0,7 & $-5,3$ & & $-5,4 ?$ & & & $-\quad 5,5$ & Bymuseet \\
\hline 1420 & 3,1 & A & 1,4 & $-5,7$ & & $-6,8 ?$ & & & $-6,8$ & Bagerstræde \\
\hline 1421 & 4,5 & A & $-1,2$ & c. $-6,1 ?$ & $-6,7 ?$ & & & & c. $-6,9$ & Det ny Teater \\
\hline 1422 & 4,6 & A & 3,1 & & & & & & $-6,4$ & Vodroffsvej \\
\hline 1423 & 3,2 & A & $0,5 ?$ & $-5,6$ & & & & & $-6,5$ & Bagerstræde \\
\hline 1424 & 2,9 & A & 1,1 & & & & & & $-\quad 5,4$ & Vesterbrogade \\
\hline 1425 & 3,4 & A & c. 0,9 & c. $-6,2$ & & & & & $-6,6$ & Bagerstræde \\
\hline 1426 & 3,4 & A & $1,2 ?$ & & & & & & $-4,7$ & Bymuseet \\
\hline 1427 & 4,6 & A & c. 1,0 & & & & & & $-6,5$ & G1. Kongevej \\
\hline $1727 a$ & & & $0,1 ?$ & & $-6,2$ & & & & c. $-6,3$ & G1. Kangevej \\
\hline $1727 b$ & & & $0,1 ?$ & $-5,9$ & $-6,2$ & & & & $-6,5$ & G1. Kongevej \\
\hline $1728 \mathrm{a}$ & & & $-1,4 ?$ & c. $-6,2$ & $-6,5 ?$ & & & & $-6,5$ & G1. Kongevej \\
\hline $1728 b$ & & & $0,1 ?$ & c. $-5,8$ & $-6,4 ?$ & & & & $-6,4$ & G1. Kongevej \\
\hline $1729 a$ & & & $0,4 ?$ & c. $-5,9$ & $-6,3 ?$ & & & & $-6,4$ & GT. Kongevej \\
\hline 17296 & & & $0,5 ?$ & c. $-5,9$ & $-6,3 ?$ & & & & c. - 6,4 & Gi1. Kongevej \\
\hline 1730 & & & $0,4 ?$ & c. . 5,9 & $-6,2 ?$ & & & & c. $-6,2$ & G1. Kongevej \\
\hline 1731 & 3,4 & A & 1,5 & c. $-5,7$ & $-6,1 ?$ & & & c & c. - 6,1 & G1. Kongevej \\
\hline 1775 & 2,6 & A & $-1,2$ & & & & & & $-9,3$ & Polititorvet \\
\hline 1776 & 2,3 & A & $-1,9$ & $-8,1$ & & & & & $-8,2$ & Polititorvet \\
\hline 1777 & 0,3 & A & 0,1 & $-7,6$ & & & & & $-8,5$ & Polititorvet \\
\hline 1801 & 5,2 & A & 4,1 & & $6,9 ?$ & & & & $-6,9$ & Forum \\
\hline 1826 & 2,2 & A & $-0,9$ & $-9,4$ & & & & & $-11,3$ & Bernstorffgade \\
\hline
\end{tabular}




\begin{tabular}{|c|c|c|c|c|c|c|c|c|c|c|}
\hline \multirow{3}{*}{$\begin{array}{l}\text { D.G.U. } \\
\text { Borearkiv } \\
\text { nr. pd } \\
\text { at } 1 \text { b } 1 \text {. nr. } \\
201\end{array}$} & \multirow{2}{*}{\multicolumn{2}{|c|}{$\begin{array}{c}\text { Terrankote } \\
\text { m }\end{array}$}} & \multicolumn{6}{|c|}{ Koter i m til top af: } & \multirow{3}{*}{$\underset{m}{\text { Siutkote }}$} & \multirow{3}{*}{ Bemærkninger } \\
\hline & & & Kvartær & Selandien & 'Ka 7 k' & \multicolumn{2}{|c|}{ Danien } & Mastrichtien & & \\
\hline & $\begin{array}{l}\text { Niv. } \\
\text { op } 1 . \\
\text { Afl. }\end{array}$ & $\begin{array}{l}A \\
B \\
C\end{array}$ & & & & KK & $B K$ & $k r i d t$ & & \\
\hline 1899 & 2,2 & A & $-3,8$ & & & $-8,1$ & & & $-8,3$ & Vasbygade \\
\hline 1902 & 2,6 & A & $-1,1$ & & & $-8,0$ & & & $-8,1$ & Vasbygade \\
\hline 1903 & 2,0 & A & $-2,0$ & & & & & & $-7,0$ & Vasbygade \\
\hline 1904 & 2,2 & A & $-2,6$ & & & $-6,6$ & & & $-6,8$ & Vasbygade \\
\hline 1925 & 4,7 & A & 2,7 & & & & & & $-6,5$ & Adelgade \\
\hline 1926 & 2,2 & A & $-1,1$ & & & & & & $-7,9$ & Christiansholm \\
\hline 1949 & 2,3 & A & $-1,7$ & & & & & & $-10,5$ & [slands $\mathrm{Br}$. KHV 326 \\
\hline 1969 & 4,2 & A & $-0,7$ & & & $-6,8$ & & & $-6,9$ & Borgergade \\
\hline 1970 & $4,2 ?$ & ?A & $-0,7 ?$ & & & $-6,5$ & & & $-19,9$ & Borgergade \\
\hline 1990 & 1,5 & A & $-3,0$ & $-10,0$ & & $-71,1$ & & & $-11,5$ & Kalkbrænderihavnsg. \\
\hline 1993 & 7.5 & A & 3,6 & & & & & & $-7,0$ & Ndr. Friharnsgade \\
\hline 2074 & 4,4 & A & c. 0,3 & & & $-9,3$ & & & $-10,7$ & Pilestræde \\
\hline 2075 & 4,4 & A & c. 0,2 & & & c. $-6,0$ & & & $-\quad 3,1$ & Pilestræde \\
\hline 2077 & & & c. 3,0 & & & c. $-6,4$ & & & $-7,8$ & Pilestræde \\
\hline 2078 & 4,4 & A & 2,4 & & & $-6,0 ?$ & & & $-6,1$ & Pilestræde \\
\hline 2079 & 3,0 & A & 0,4 & & & $-6,0$ & & & -6.0 & Pilestræde \\
\hline 2085 & 1,8 & A & 1,0 & & & $-6,0$ & & & $-6,0$ & Pilestræde \\
\hline 2086 & 1,8 & A & 1,0 & & & & & & $-6,7$ & Pilestræde \\
\hline 2088 & 1,8 & A & 0,7 & & & & & & $-6,1$ & Pilestræde \\
\hline 2122 & 8,1 & A & 5,8 & & & $-13,9$ & & & $-15,9$ & Blegdamsvej \\
\hline 2123 & 7,8 & A & $7,8 ?$ & & & $-9,5$ & & & $-11,4$ & Blegdamsvej \\
\hline 2130 & 9,1 & A & 8,8 & & & $-16,4$ & & & $-16,6$ & B legdamsvej \\
\hline 2167 & 2,2 & A & c. 2,0 & & & c. $-16,0$ & & & $-16,3$ & B. legdamsvej \\
\hline 2168 & 7,8 & A & 6,3 & & & c. $-14,3$ & & & $-14,6$ & Blegdamsvej \\
\hline 2235 & 1,9 & A & $-0,4$ & & & $-10,3 ?$ & & & $-10,3$ & Strandgade \\
\hline 2236 & 1,9 & A & $-2,5$ & & & $-10,1$ & & & $-10,7$ & Strandgade \\
\hline 2263 & 2,4 & A & 0,0 & & & $-6,8 ?$ & & & $-7,0$ & Niels Juelsgade \\
\hline 2264 & 1,9 & A & $-0,8$ & & & - $7,0 ?$ & & & $-7,0$ & Niels Juelsgade \\
\hline 2265 & 2,2 & A & $-0,6$ & & & & & & $-7,0$ & Niels Juelsgade \\
\hline 2266 & 2,4 & A & $-2,4$ & & & & & & $-7,3$ & Niels Juelsgade \\
\hline 2267 & 2,0 & A. & $-0,2$ & & & $-6,9$ & & & $-16,2$ & Niels Juelsgade \\
\hline 2268 & 2,1 & A & 0,1 & & & $-6,8$ & & & $-7,0$ & "1 \\
\hline 2269 & 2,3 & A & 0,2 & & & $-7,0 ?$ & & & $-7,2$ & $"$ \\
\hline 2270 & 2,4 & A & c. $-0,3$ & & & $-7,1 ?$ & & & $-7,3$ & $"$ \\
\hline 2271 & 2,1 & A & 0,0 & & & $-6,1$ & & & $-6,2$ & " \\
\hline 2272 & 2,0 & A & 0,0 & & & c. $-6,7$ & & & $-14,4$ & Niels Juelsgade \\
\hline 2273 & 2,3 & A & $-0,3$ & & & $-6,9$ & & & $-15,0$ & Niels Juelsgade \\
\hline 2275 & 4,0 & A & 1,6 & c. $-7,9$ & & & & & $-9,7$ & Nyropsgade \\
\hline 2276 & 3,8 & A & $-0,3$ & $-7,5$ & & $-9,0$ & & & $-9,4$ & Nyropsgade \\
\hline 2277 & 4,0 & A & 0,9 & $-7,6 ?$ & & & & & $-8,0$ & Nyropsgade \\
\hline 2278 & 6,3 & A & 1,5 & $-8,9$ & & & & & $-8,9$ & Nyropsgade \\
\hline 2279 & 3,9 & A & 0,5 & $-7,7$ & & $-8,8$ & & & $-9,5$ & Nyropsgade \\
\hline 2389 & 1,4 & A & 0,3 & & & $-7,5$ & & & $-7,8$ & Pilestræde \\
\hline 2457 & 0,0 & B & $-5,0$ & & & $-9,8$ & & & $-9,9$ & Wilders P1. KHV 340 \\
\hline 2458 & 0,0 & B & $-3,2$ & & & & & & $-7,7$ & Wilders P1. KHV 341 \\
\hline 2459 & 0,0 & B & $-6,0$ & & & $-9,3$ & & & $-9,4$ & Wilders P1. KHV 342 \\
\hline 2460 & 0,0 & $B$ & $-5,0$ & & & $-7,7 ?$ & & & $-7,8$ & Wilders P1. KHV 343 \\
\hline 2489 & c. 13,0 & B & & & & c. $-10,2$ & & & c. $-50,0$ & Militærhospitalet. \\
\hline 2528 & c. 1,3 & $c$ & c. 1,0 & & & $-5,7 ?$ & & & $-5,7$ & Siljansgade \\
\hline 2529 & c. 1,3 & C & c. 1,0 & & & $-5,7$ & & & $-7,4$ & Siljansgade \\
\hline 2530 & c. 7,3 & c & c. 1,0 & & & $-5,7$ & & & $-5,9$ & Siljansgade \\
\hline 2531 & c. 1,3 & c & c. 1,0 & & & $-5,9 ?$ & & & $-\quad 5,9$ & Siljansgade \\
\hline 2568 & 1,9 & A & $-1,4$ & & & & & & $-11,7$ & Kalvebod Brygge \\
\hline 2569 & 1,8 & A & 0,2 & $-12,5 ?$ & & & & & $-12,6$ & Kalvebod Brygge \\
\hline 2617 & 4,0 & A & 0,8 & $-7,2$ & & & & & $-9,8$ & Herholdtgade \\
\hline
\end{tabular}




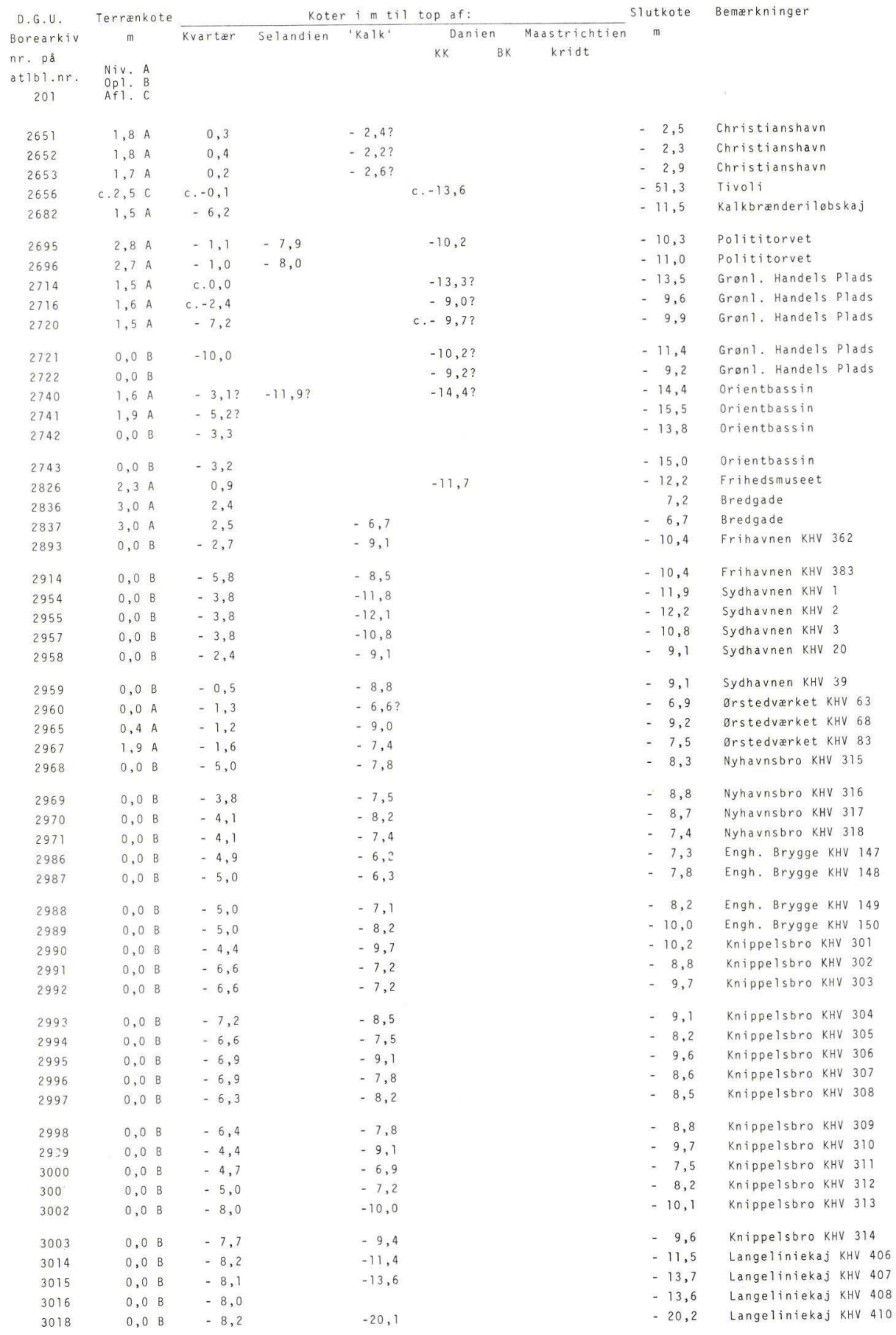




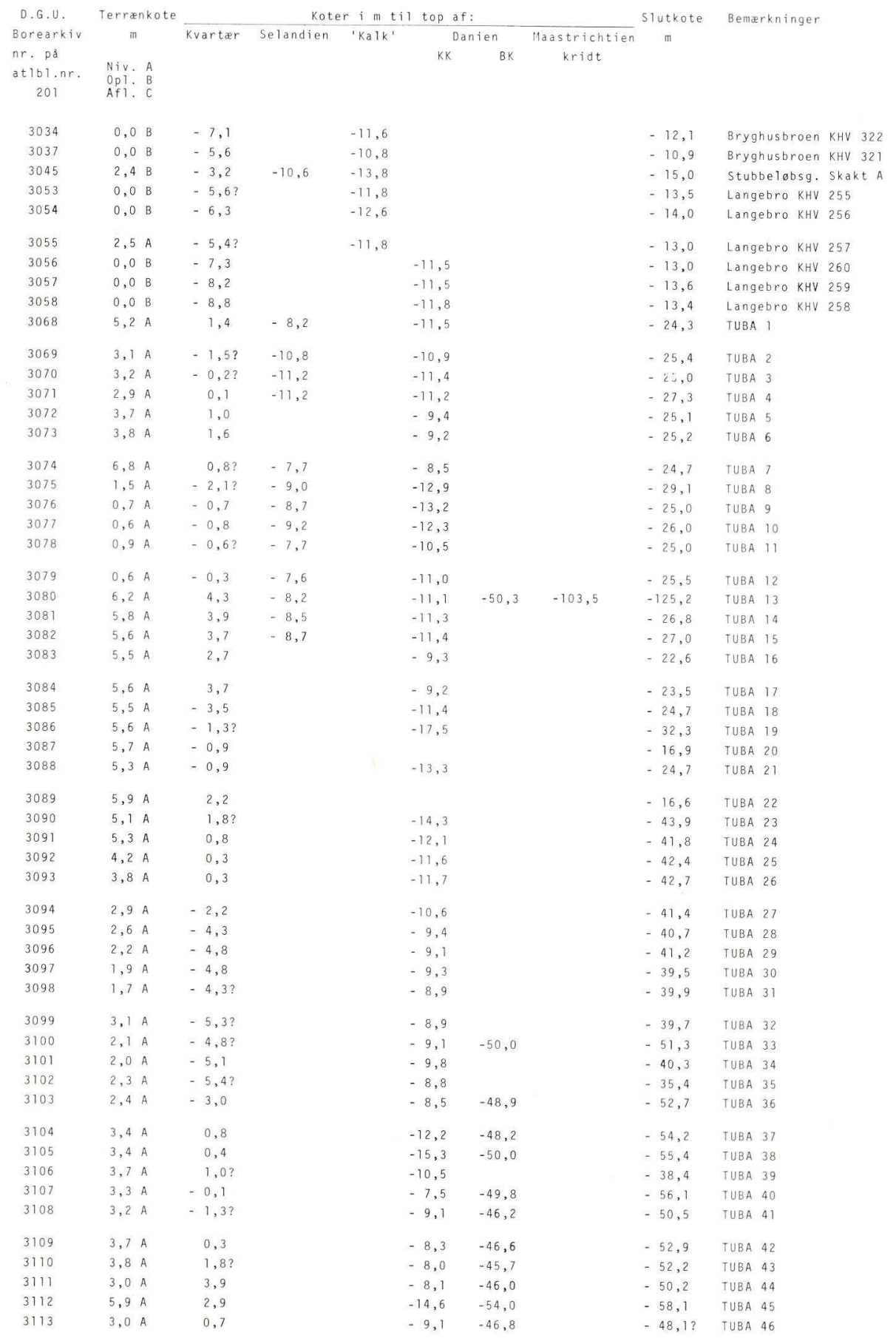




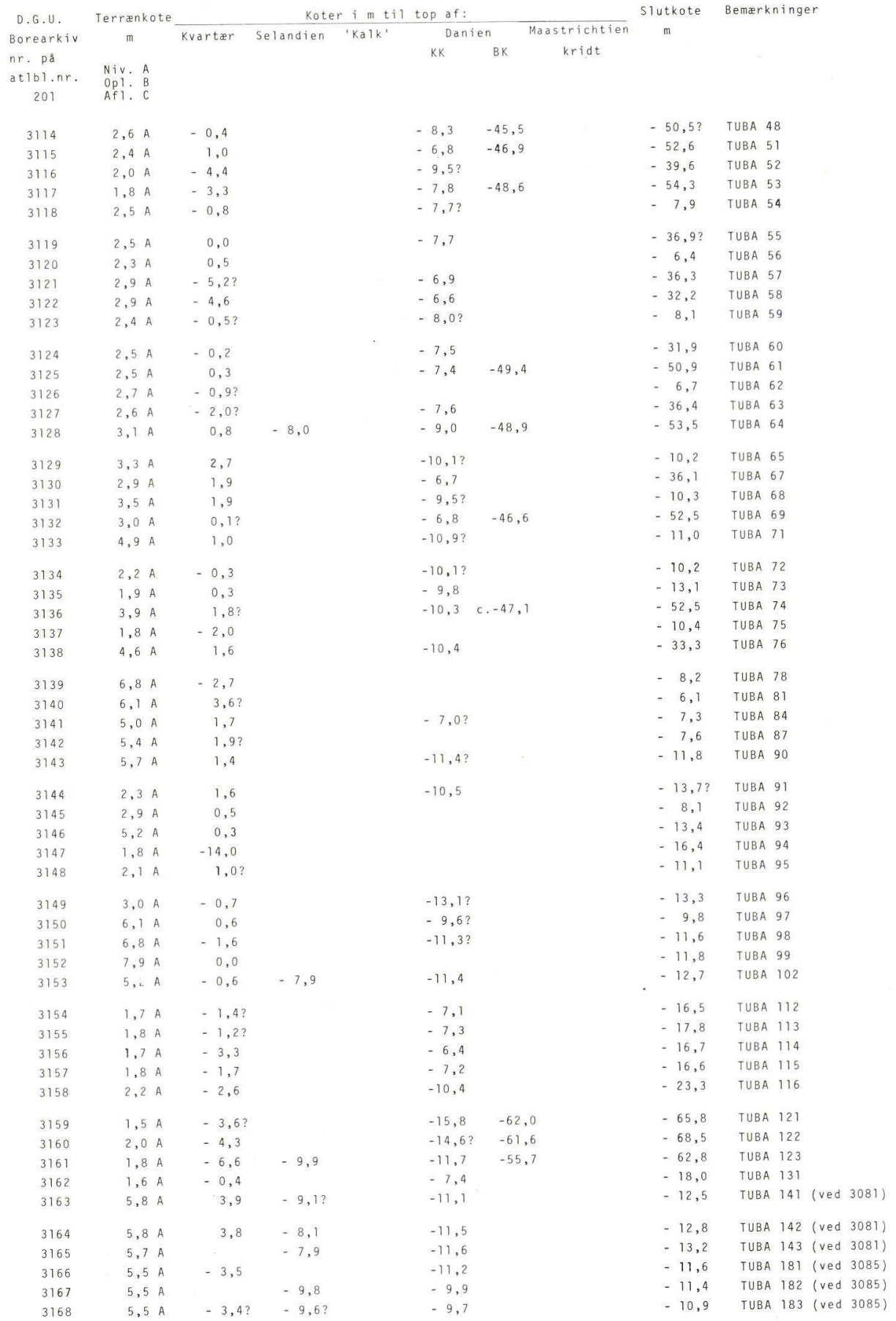




\begin{tabular}{|c|c|c|c|c|c|c|c|c|c|c|c|c|c|}
\hline \multirow{3}{*}{$\begin{array}{l}\text { D.G.U, } \\
\text { Borearkiv } \\
\text { nr. pa } \\
\text { atibl.nr. } \\
\quad 201\end{array}$} & \multirow{2}{*}{\multicolumn{2}{|c|}{$\begin{array}{c}\text { Terrænkote } \\
m\end{array}$}} & \multicolumn{6}{|c|}{ Koter i m til top af: } & \multirow{3}{*}{ Slutkote } & \multirow{2}{*}{\multicolumn{4}{|c|}{ Bemærkninger }} \\
\hline & & & \multirow[t]{2}{*}{ kvartær } & \multirow[t]{2}{*}{ Selandien } & \multirow[t]{2}{*}{ 'Kalk' } & \multicolumn{2}{|c|}{ Danien } & \multirow{2}{*}{$\begin{array}{c}\text { Maastrichtien } \\
\text { kridt }\end{array}$} & & & & & \\
\hline & $\begin{array}{l}\text { Niv. } \\
\text { Opl. } \\
\text { Afl. }\end{array}$ & $\begin{array}{l}A \\
B \\
C\end{array}$ & & & & KK & $B K$ & & & & & & \\
\hline 3169 & 6,1 & A & $-1,0$ & $-8,9$ & & $-8,9$ & & & $-18,9$ & TUBA & 197 & & \\
\hline 3170 & 6,7 & A & 2,9 & $-7,9$ & & $-10,5$ & & & $-27,1$ & TUBA & 192 & & \\
\hline 3171 & 4,8 & A & 1,7 & $-7,0$ & & c. $-8,4$ & & & $-18,9$ & TUBA & 193 & & \\
\hline 3172 & 6,6 & A & 3,8 & & & $-16,9$ & & & $-22,7$ & TUBA & 194 & & \\
\hline 3173 & 6,7 & A & 5,3 & & & $-10,8$ & & & $-20,9$ & TUBA & 195 & & \\
\hline 3174 & 2,4 & A & $-1,8$ & & & $-10,7$ & & & $-21,1$ & TUBA & 196 & & \\
\hline 3175 & 2,2 & A & $-0,9$ & & & $-10,1$ & & & $-20,7$ & TUBA & 197 & & \\
\hline 3176 & 4,9 & A & 1,1 & & & $-9,9$ & & & $-20,9$ & TUBA & 198 & & \\
\hline 3177 & 7,1 & A & c. 3,9 & & & $-9,4$ & & & $-16,9$ & TUBA & 199 & & \\
\hline 3178 & 3,1 & A & $-1,3 ?$ & $-10,7$ & & & & & $-10,8$ & TUBA & 201 & (ved & $3069)$ \\
\hline 3179 & 5,7 & A & $-2,0 ?$ & & & c. $-18,3$ & & & $-32,8 ?$ & TUBA & 202 & L (ved & $3087)$ \\
\hline 3180 & 5,7 & A & $-0,5 ?$ & & & $-18,4 ?$ & & & $-18,6$ & TUBA & 203 & (ved & $3087)$ \\
\hline 3181 & 5,7 & A & $-2,8$ & & & & & & $-16,4$ & TUBA & 204 & (ved & $\left.3087^{\circ}\right)$ \\
\hline 3182 & 2,0 & A & $-2,0$ & & & & & & $-14,2$ & TUBA & 205 & & \\
\hline 3183 & 2,7 & A & $-1,3$ & & & $-11,9$ & & & $-14,3 ?$ & TUBA & 206 & & \\
\hline 3184 & 3,9 & A & $-2,1$ & & & $-19,1$ & & & $-23,5$ & TUBA & 207 & & \\
\hline 3185 & 6,9 & A & $2,9 ?$ & & & $-22,6$ & & & $-27,1$ & TUBA & 208 & & \\
\hline 3186 & 8,0 & A & 4,1 & & & $-23,1$ & & & $-26,6$ & TUBA & 209 & & \\
\hline 3187 & 8,7 & A & 5,9 & & & $-13,3$ & & & $-23,5$ & TUBA & 221 & & \\
\hline 3188 & 6,2 & A & $3,3 ?$ & & & & & & $-18,8$ & $T \cup B A$ & 222 & & \\
\hline 3189 & 4,8 & $A$ & 1,6 & & & $-9,1$ & & & $-21,2$ & $T \cup B A$ & 223 & & \\
\hline 3190 & 8,4 & A & & & & & & & 1,2 & $T \cup B A$ & 224 & & \\
\hline 3191 & 5,1 & A & c. 3,0 & & & & & & $-13,3$ & TUBA & 231 & & \\
\hline 3192 & 5,1 & A & $-0,4$ & & & $-14,5$ & & & $-17,0$ & $T \cup B A$ & 232 & (ved & $3090)$ \\
\hline 3193 & 5,7 & A & 0,8 & & & $-14,2$ & & & $-16,7$ & TUBA & 233 & lved & $3090)$ \\
\hline 3194 & 3,8 & A & $0,2 ?$ & & & $-11,3$ & & & $-13,1$ & TUBA & 261 & (ved & $3093)$ \\
\hline 3195 & 3,7 & A & $-1,8 ?$ & & & c. $-11,5$ & & & $-13,1$ & TUBA & 262 & (ved & $3093)$ \\
\hline 3196 & 3,9 & A & $=1,7$ & & & $-12,2$ & & & $-13,4$ & TUBA & 263 & lved & $3093)$ \\
\hline 3197 & 2,6 & A & $-4,1 ?$ & & & $-9,6 ?$ & & & $-10,8$ & TUBA. & 281 & (ved & 30951 \\
\hline 3198 & 2,0 & A & $-5,5 ?$ & & & $-11,0$ & $-51,1$ & & $-55,3$ & TUBA & 291 & lved & $3096)$ \\
\hline 3199 & 3,2 & A & $-1,0 ?$ & $-11,1$ & & c. $-11,4$ & & & $-12,3$ & TUBA & 301 & lved & $3070)$ \\
\hline 3200 & 3,1 & A & & $-11,2$ & & c. $-11,5$ & & & c. $-12,4$ & TUBA & 302 & lved & 30701 \\
\hline 3201 & 3,1 & A & $-2,1 ?$ & $-11,3$ & & $-11,7$ & & & $-12,3$ & TUBA & 303 & lved & $3070)$ \\
\hline 3202 & 1,8 & A & $-4,8$ & & & $-9,9$ & & & $-13,1$ & TUBA & 304 & (ved & $3097)$ \\
\hline 3203 & 2,0 & A & $-4,7 ?$ & & & $-10,1$ & & & $-13,7$ & TUBA & 305 & (ved & 30971 \\
\hline 3204 & c. 2,1 & A & $-4,6 ?$ & & & $-9,3 ?$ & & & $-17,5 ?$ & TUBA & 331 & lved & $3100)$ \\
\hline 3205 & 2,1 & A & $-4,5 ?$ & $-9,2$ & & $-9,2$ & & & $-11,4$ & TUBA & 332 & lved & $(3100)$ \\
\hline 3206 & 2,0 & A & $-3,9 ?$ & $-9,1 ?$ & & $-9,2 ?$ & & & $-11,4$ & TUBA & 333 & lved & $3100)$ \\
\hline 3207 & 2,4 & A & $-2,6$ & & & $-8,2$ & & & $-10,4$ & TUBA & 36.1 & fved & $(3103)$ \\
\hline 3208 & 2,5 & A & $-3,3 ?$ & & & $-8,0$ & & & $-10,9$ & TUBA & 362 & (ved & 3103) \\
\hline 3209 & 2,5 & A & $-2,8$ & & & $-9,2$ & & & $-12,1$ & TUBA & 363 & (ved & 3103) \\
\hline 3210 & 3,4 & A & 0,8 & & & $-12,2$ & & & $-15,2$ & TUBA & 371 & (ved & $3104)$ \\
\hline 3211 & 3,4 & A & 0,9 & & & $-12,3 ?$ & & & $-15,3$ & TUBA & 372 & (ved & $3104)$ \\
\hline 3212 & 3,3 & A & $-0,7$ & & & $-13,7$ & & & $-17,5$ & TUBA & 373 & (ved & $3104)$ \\
\hline 3213 & 3,5 & A & 0,5 & & & $-15,9$ & & & $-23,0$ & TUBA & 381 & (ved & $3105)$ \\
\hline 3214 & 3,7 & A & $1,0 ?$ & & & $-10,6$ & & & $-13,6$ & TUBA & 391 & (ved & $3106)$ \\
\hline 3215 & 3,8 & A & 0,8 & & & $-10,4 ?$ & & & $-13,5$ & TUBA & 392 & (ved & $3106)$ \\
\hline 3216 & 3,8 & A & $-0,1 ?$ & & & $-70,1$ & & & $-14,2$ & TUBA & 393 & (ved & $3106)$ \\
\hline 3217 & 3,4 & A & $-0,1$ & & & $-9,2 ?$ & & & $-19,2$ & $T \cup B A$ & 394 & & \\
\hline 3218 & 2,9 & A & $0,1 ?$ & & & & & & $-6,3$ & TUBA & 401 & (ved & $3071)$ \\
\hline 3219 & 2,5 & A & $-0,8$ & $-5,5$ & & $-8,0$ & & & $-10,6$ & TUBA & 402 & & \\
\hline 3220 & 5,2 & A & 0,8 & & & $-3,8$ & & & $-\quad 7,0$ & TUBA & 403 & & \\
\hline 3221 & 3,4 & A & 0,6 & & & & & & $-\quad 9,1$ & TUBA & 404 & (red & $3266)$ \\
\hline 3222 & 3,3 & A & $-1,5$ & & & $-11,0$ & & & $-14,7$ & TUBA & 405 & lved & 32661 \\
\hline 3223 & 3,4 & A & $-0,9$ & & & $-10,7 ?$ & & & $-12,1$ & TUBA & 406 & lved & $3266)$ \\
\hline
\end{tabular}

D. G. U. III. rk. nr. 45 


\begin{tabular}{|c|c|c|c|c|c|c|c|c|c|c|c|c|c|}
\hline \multirow{4}{*}{$\begin{array}{l}\text { D.G.U. } \\
\text { Borearkiv } \\
\text { nr. pá } \\
\text { at } 1 \text { bl.nr. } \\
201\end{array}$} & \multirow{2}{*}{\multicolumn{2}{|c|}{$\begin{array}{c}\text { Terrænkote } \\
\text { mi }\end{array}$}} & \multicolumn{3}{|c|}{ Koter i m til } & top af: & & & Siutkote & \multicolumn{3}{|c|}{ Bemærkninger } & \\
\hline & & & \multirow[t]{2}{*}{ Kvartær } & \multirow[t]{2}{*}{ Selandien } & \multirow[t]{3}{*}{ 'Kalk' } & \multicolumn{2}{|c|}{ Danien } & \multirow{3}{*}{$\begin{array}{l}\text { Mastrichtien } \\
\text { kridt }\end{array}$} & \multirow[t]{3}{*}{ m } & & & & \\
\hline & & & & & & KK & $B K$ & & & & & & \\
\hline & $\begin{array}{l}\text { Niv. } \\
\text { Opl: } \\
\text { Afl. }\end{array}$ & $\begin{array}{l}A \\
B \\
C\end{array}$ & & & & & & & & & & & \\
\hline 3224 & 3,5 & A & $-0,7 ?$ & & & $-10,7$ & & & $-12,5$ & $T U B A$ & 407 & (ved & $3266)$ \\
\hline 3225 & 3,3 & A & $-0,7$ & & & $-10,7 ?$ & & & $-12,7$ & TUBA & 408 & (ved & $3266)$ \\
\hline 3226 & 4,7 & A & $3,1 ?$ & $-7,7 ?$ & & & & & $-9,3$ & TUBA & 409 & & \\
\hline 3227 & 2,9 & A & $-1,2$ & $-9,6 ?$ & & $-10,9 ?$ & & & $-14,9$ & TUBA & 410 & & \\
\hline 3228 & 3,2 & A & $-1,9 ?$ & & & $-8,1$ & & & $-18,8$ & TUBA & 411 & (ved & 3108) \\
\hline 3229 & 3,3 & A & $-3,3 ?$ & & & $-8,7$ & & & $-19,1$ & TUBA & 412 & (ved & $3108)$ \\
\hline 3230 & 3,4 & A & $-1,2$ & & & $-9,6$ & & & $-19,7$ & TUBA & 413 & (ved & 3108) \\
\hline 3231 & 2,6 & A & 0,1 & & & $-8,3$ & & & $-18,9$ & TUBA & 481 & (ved & $3174)$ \\
\hline 3232 & 2.6 & A & $-0,8 ?$ & & & $-8,2 ?$ & & & $-17,7$ & TUBA & 482 & (ved & $3174)$ \\
\hline 3233 & 2,6 & A & $-1,0$ & & & $-8,0$ & & & $-18,8$ & TUBA & 483 & (ved & $3114)$ \\
\hline 3234 & 3,7 & A & $1,0 ?$ & & & $-9,4$ & & & $-10,4$ & TUBA & 5011 & lved & $3072)$ \\
\hline 3235 & 3,7 & A & 0,4 & & & $-9,5$ & & & $-10,5$ & TUBA & 502 & lved & $3072)$ \\
\hline 3236 & 3,6 & A & 0,6 & & & $-10,0$ & & & $-11,4$ & TUBA & 503 & lved & $3072)$ \\
\hline 3237 & 3,4 & A & 0,7 & & & & & & $-8,7$ & TUBA & 506 & lved & $3266)$ \\
\hline 3239 & 2,5 & A & 0,5 & $-7,6$ & & $-7,6$ & & & $-17,5$ & TUBA & 541 & (ved & $3118)$ \\
\hline 3240 & 2,6 & A & $-1,7$ & $-7,6$ & & -7.6 & & & $-18,1$ & TUBA & 542 & (ved & $3118)$ \\
\hline 3241 & 2,8 & A & $-0,3$ & & & $-6,5$ & & & $-16,3 ?$ & TUBA & 543 & (ved & 31181 \\
\hline 3242 & 2,7 & A & $-0,6 ?$ & & & $-5,8$ & & & $-17,3$ & TUBA & 554 & & \\
\hline 3243 & 2,4 & A. & 0,1 & & & $-7,6$ & & & $-16,6$ & TUBA & 555 & & \\
\hline 3244 & 2,9 & A & 0,4 & & & $-6,5$ & & & $-17,2$ & TUBA & 571 & (ved & $3121)$ \\
\hline 3245 & 2,8 & A & $-1,4$ & & & $-6,7$ & & & $-17,2$ & TUBA & 572 & Sved: & $3121)$ \\
\hline 3246 & 2,1 & A & $-0,9$ & $-7,0$ & & $-7,7$ & & & $-17,2 ?$ & TUBA & 573 & & \\
\hline 3247 & 2,1 & A & $-0,6$ & & & $-7,0$ & & & $-16,4$ & TUBA & 574 & & \\
\hline 3248 & 4,6 & A & $-0,7$ & & & $-9,1$ & & & $-20,3 ?$ & TUBA & 575 & & \\
\hline 3249 & 4,2 & A & 1,5 & & & $-6,8$ & & & $-18,6$ & TUBA & 576 & & \\
\hline 3250 & 2,1 & A & $-0,9$ & & & $-7,5$ & & & $-17,5$ & TUBA & 577 & & \\
\hline 3251 & 2,6 & A & 0,0 & & & $-6,8$ & & & $-17,3$ & TUBA & 585 & & \\
\hline 3252 & 2,6 & A & $-1,7$ & & & $-7,3$ & & & $-17,5$ & TUBA & 631 & (ved: & 3127) \\
\hline 3253 & 2,2 & A & $-1,3 ?$ & & & $-7,9$ & & & $-18,2$ & TUBA & 633 & (ved & $3127)$ \\
\hline 3254 & 1,4 & A & $-1,7$ & & & $-7,2$ & & & $-16,4$ & TUBA & 634 & & \\
\hline 3255 & 2,1 & A & $-3,3 ?$ & & & $-6,1$ & & & $-16,5$ & TUBA & 635 & & \\
\hline 3256 & 2,2 & A & & & & $-9,2$ & & & $-18,5$ & TUBA & 636 & & \\
\hline 3257 & 4,3 & A & c. 0,0 & & & & & & $-0,5$ & TUBA & 637 & & \\
\hline 3258 & 4,4 & A & 0,6 & & & & & & $-0,8$ & TUBA & 638 & & \\
\hline 3259 & 5,2 & A & & & & & & & 1,7 & TUBA & 639 & & \\
\hline 3260 & 3,4 & A & 1,1 & $-7,2$ & & $-7,2$ & & & $-17,3$ & TUBA & 673 & & \\
\hline 3261 & 4,4 & A & 2,6 & & & $-13,6$ & & & $-23,8$ & TUBA & 674 & & \\
\hline 3263 & 3,2 & A & 1,9 & & & $-7,8$ & & & $-17,4$ & TUBA & 702 & & \\
\hline 3264 & 3,8 & A & 1,8 & & & $-11,2$ & & & $-20,9 ?$ & TUBA & 741 & & \\
\hline 3266 & 3,5 & A & 0,5 & & & & & & $-\quad 7,9$ & TUBA & 505 & (Prove & (efelt) \\
\hline 3267 & 9,9 & A & $c .3,1$ & & & $-9,4 ?$ & & & $-20,1$ & TUBA & 212 & & \\
\hline 3268 & 8,1 & A & 6,5 & & & $-8,8$ & & & $-18,8$ & TUBA & 213 & & \\
\hline 3269 & 2,0 & A & c. $-3,4$ & & & $-9,0$ & & & $-19,2$ & TUBA & 521 & (ved 3 & $3716)$ \\
\hline 3270 & 2,0 & A & c. $-2,9$ & & & $-8,9$ & & & $-19,3$ & TUBA & 522 & (ved: & $3116)$ \\
\hline 3271 & 4,3 & A & $-1,5$ & & & $-9,1$ & & & $-18,4$ & TUBA & 523 & & \\
\hline 3272 & 3,8 & A & $-1,8$ & & & & & & $-2,2$ & TUBA & 524 & & \\
\hline 3273 & 2,9 & A & 0,4 & & & $-6,6$ & & & $-16,6$ & TUBA & 671 & (ved 3 & $3730)$ \\
\hline 3541 & 2,3 & A & $-0,8$ & & & & & & $-10,9$ & Kobent & nhavn & is gods & sbaneg. \\
\hline 3542 & 2,6 & A & $-0,6$ & & $-10,6$ & & & & $-10,6$ & Friha & an $s$ & tation & \\
\hline 3545 & 2,5 & A & 1,3 & $-7,9 ?$ & & $-9,2 ?$ & & & $-9,3$ & Svaner & mo 11 & en & \\
\hline 3546 & 2,5 & A & 1,2 & & & & & & $-9,3$ & Svaner & emolle & len & \\
\hline 3547 & 2,5 & A & 1.9 & & & $-9,5 ?$ & & & $-9,5$ & Svaner & emø 11 & len & \\
\hline 3548 & 4,5 & A & 2,5 & & & $-10,0 ?$ & & & $-10,0$ & Svaner & emol1 & en & \\
\hline 3549 & 2,6 & A & 2,5 & & & $-8,7 ?$ & & & $-9,2$ & Svaner & $m ø 11$ & len & \\
\hline 3555 & 1,4 & A & 1,4 & $-8,6$ & & c. $-9,2$ & & & $-11,6$ & Svaner & emø 11 & Ten & \\
\hline
\end{tabular}




\begin{tabular}{|c|c|c|c|c|c|c|c|c|c|}
\hline D.G.U. & Terrænkote & & Kot & $r i m$ til & top af: & & & Slutkote & Bemærkninger \\
\hline Borearkiv & & Kvartær & Selandien & 'Kalk' & Dani & & Madtrichtien & m & \\
\hline $\begin{array}{l}n r \cdot p \& \\
\text { at } 1 \text { bl.nr. } \\
201\end{array}$ & $\begin{array}{ll}\text { Niv. } & \text { A } \\
\text { Opli. } & \text { B } \\
\text { Afl. } & \text { C }\end{array}$ & & & & KK & BK & kridt & & \\
\hline 3556 & $1,4 \mathrm{~A}$ & 1,4 & & & $-10,6 ?$ & & & $-10,6$ & Svanemollen \\
\hline 3557 & $1,8 \mathrm{~A}$ & 1,8 & & & $-10,1$ & & & $-16,3$ & Svanemollen \\
\hline 3558 & $1,9 \mathrm{~A}$ & 1,9 & & & $-8,8$ & & & $-13,1$ & Svanemollen \\
\hline 3559 & $2,3 \mathrm{~A}$ & 2,0 & & & $-8,8$ & & & $-13,2$ & Svanemollen \\
\hline 3560 & $2,2 \mathrm{~A}$ & 2,2 & & & $-8,5$ & & & $-13,4$ & Svanemollen \\
\hline 3561 & $4,5 \mathrm{~A}$ & $1,5 ?$ & & & $-9,0$ & & & $-12,5$ & Svanemollen \\
\hline 3562 & $2,6 \mathrm{~A}$ & 1,7 & & & $-9,0$ & & & $-13,4$ & Svanemollen \\
\hline 3563 & $8,4 \mathrm{~A}$ & 6,2 & & & $-11,4 ?$ & & & $-13,5$ & Svanemollen \\
\hline 3564 & $3,1 A$ & 2,8 & & & & & & $-13,0$ & Svanemollen \\
\hline 3565 & $8,4 \mathrm{~A}$ & $4,6 ?$ & & & $-11,7 ?$ & & & $-13,7$ & Svanemollen \\
\hline 3566 & $3,4 \mathrm{~A}$ & 3,3 & & & & & & $-12,1$ & Svanemollen \\
\hline 3567 & $8,3 \mathrm{~A}$ & $5,1 ?$ & & & $-11,0 ?$ & & & $-12,8$ & Svanemollen \\
\hline 3616 & $1,9 \mathrm{~A}$ & $-2,5$ & & $-11,2$ & & & & $-24,3$ & Sydharnstunnelen \\
\hline 3617 & $c,-2,4 B$ & $-2,4$ & & $-10,9$ & & & & $-28,2$ & Sydhavnstuninelen \\
\hline 3618 & c. $-7,5 \mathrm{~B}$ & $-7,5$ & & $-10,2$ & & & & $-23,8$ & Sydhavnstunnelen \\
\hline 3619 & C. $-0,3 B$ & $-1,1$ & $-9,9$ & $-10,0$ & & & & $-31,5$ & Sydhavnstunnelen \\
\hline 3627 & $c .13,0 \mathrm{c}$ & 13,0 & & $-16,1$ & & & & $-82,3$ & Lyngbyvej \\
\hline 3640 & $6,9 \mathrm{~A}$ & 3,1 & $-7,4$ & & & & & $-8,1$ & Rosenorns Allé \\
\hline 3641 & $6,4 \mathrm{~A}$ & 3,4 & $-7,8$ & & $-8,6 ?$ & & & $-8,6$ & Peblinge Dossering \\
\hline
\end{tabular}




\begin{tabular}{|c|c|c|c|c|c|}
\hline $\begin{array}{l}\text { Lab. } \\
n r \text {. }\end{array}$ & $\begin{array}{l}\text { Top af } \\
\text { lab.nr. } \\
\text { Kote, m. }\end{array}$ & $\begin{array}{l}\text { cm under } \\
\text { top af } \\
\text { lab.nr. }\end{array}$ & $\begin{array}{l}\text { Laggrænser, } \\
\text { Koter i m. }\end{array}$ & $\begin{array}{l}\text { Bjergarter, jordarter } m . v \text {. } \\
(F=\text { foraminiferprove, } K K=k a l k s a n d s k a l k, B K=\text { bryozokalk, } \\
S L K=\text { slamkalk, } S K=k r i d t, U K=\text { uregelmæssig kalktype })\end{array}$ & $\begin{array}{l}\text { Alder } \\
\text { (Formation) }\end{array}$ \\
\hline & & & 6,2 & Gadeniveau & \\
\hline & & & 5,9 & Fyld, overkant & \\
\hline 001 & 5,7 & & & Fyld. Sand, muldet, stenet, leret & \\
\hline 002 & 5,2 & & & do. & \\
\hline \multirow[t]{2}{*}{003} & 4,7 & & & do. & \\
\hline & & & 4,3 & Moræneler, overkant & Glacialt \\
\hline 004 & 4,2 & & & Moræneler, sandet, stenet, ret rent & \\
\hline \multirow[t]{2}{*}{005} & 3,7 & & & do., ret fedt, ret enskornet, med lidt grus & \\
\hline & & & 3,3 & Morænesand, overkant & \\
\hline 006 & 3,2 & & 3,0 & $\begin{array}{l}\text { Morænesand, let leret, stenet } \\
\text { Moræneler, overkant }\end{array}$ & \\
\hline 007 & 2,7 & & & Moræneler, meget sandet, stenet & \\
\hline 008 & 2,2 & & & do., ret fedt, stenet & \\
\hline \multirow[t]{2}{*}{009} & 1,7 & & & do., lerrigt, sandet, stenet & \\
\hline & & & 1,3 & Diluvialsand, overkant & \\
\hline 010 & 1,2 & & & Diluvialsand, fint, velsorteret & \\
\hline 011 & 0,7 & & & do., småstenet, ret ringe sorteringsgrad & \\
\hline 012 & 0,2 & & & do., stenet & \\
\hline 013 & $-0,3$ & & & do. & \\
\hline \multirow[t]{2}{*}{014} & $-0,5$ & & & Moræneler, meget sandet, stenet & \\
\hline & & & $-0,7$ & Grundvandsstand & \\
\hline 015 & $-0,8$ & & $-0,9$ & $\begin{array}{l}\text { Diluvialsand, mellemkornet, med lerlag } \\
\text { Moræneler, overkant }\end{array}$ & \\
\hline 016 & $-1,3$ & & & Moræneler, sandet, stenet & \\
\hline 017 & $-1,8$ & & & do., sandet, stenet, mere leret & \\
\hline 018 & $-2,3$ & & & do., sandet, stenet & \\
\hline 019 & $-3,1$ & & & do., hærdnet & \\
\hline 020 & $-3,8$ & & & do., grusrigt? & \\
\hline 021 & $-4,8$ & & & do., federe, stenet, kalkrigt & \\
\hline 022 & $-5,3$ & & & Kalkmasse, morænepræget? Los flage & \\
\hline 023 & $-5,8$ & & & do. & \\
\hline 024 & $-6,3$ & & & do. & \\
\hline 025 & $-6,8$ & & & Moræneler, sandet, stenet, kalkrigt & \\
\hline 026 & $-7,3$ & & & do., meget sandet, stenet & \\
\hline \multirow[t]{4}{*}{027} & $-7,9$ & $0-10$ & & do. & \\
\hline & & $10-25$ & $-8,15$ & $\begin{array}{l}\text { KK, hærdnet med forkislede partier. Løs flage } \\
\text { Gronsandsler, overkant }\end{array}$ & $\begin{array}{l}\text { Paleocæn, } \\
\text { selandien }\end{array}$ \\
\hline & & $25-65$ & & $\begin{array}{l}\text { Grønsandsler, mørkt olivenbrunt, vekslende lagdelt, } \\
\text { ret fedt med siltrige partier, overst } \\
\text { lidt morænepræget. (F } \div 8,53 \text { : Selandien) }\end{array}$ & $\begin{array}{l}\text { (Lel1inge } \\
\text { Gronsand) }\end{array}$ \\
\hline & & & $-8,55$ & Gronsandssilt, overkant & \\
\hline 028 & $-8,55$ & $0-90$ & -125 & $\begin{array}{l}\text { Gronsandssilt, olivengrát, let leret med pletter af } \\
\text { glaukonit og skaller, let hærdnet } \\
\text { do., med vertikal sprække }\end{array}$ & \\
\hline \multirow[t]{7}{*}{029} & $-9,85$ & $0-40$ & & do., med vertikal sprække & \\
\hline & & -85 & & do., hærdnet med $70^{\circ}$ sprække & \\
\hline & & -115 & & do., med små kalkkorn, hærdnet, med $65^{\circ}$ sprække & \\
\hline & & & $-11,00$ & Gronsandsbundkonglomerat, overkant & \\
\hline & & -120 & & Gronsandsbundkonglomerat, hærdnet & \\
\hline & & & $-11,05$ & Kk, overkant & Danien \\
\hline & & -145 & & KK, hvidgrå, med gronsandsfyldte hulrum, hærdnet & $\begin{array}{l}\text { (København } \\
\text { Ka)k) }\end{array}$ \\
\hline 030 & $-11,30$ & $0-30$ & & do., stedvis lidt konglomeratisk, med skalsammenhobninger & \\
\hline
\end{tabular}




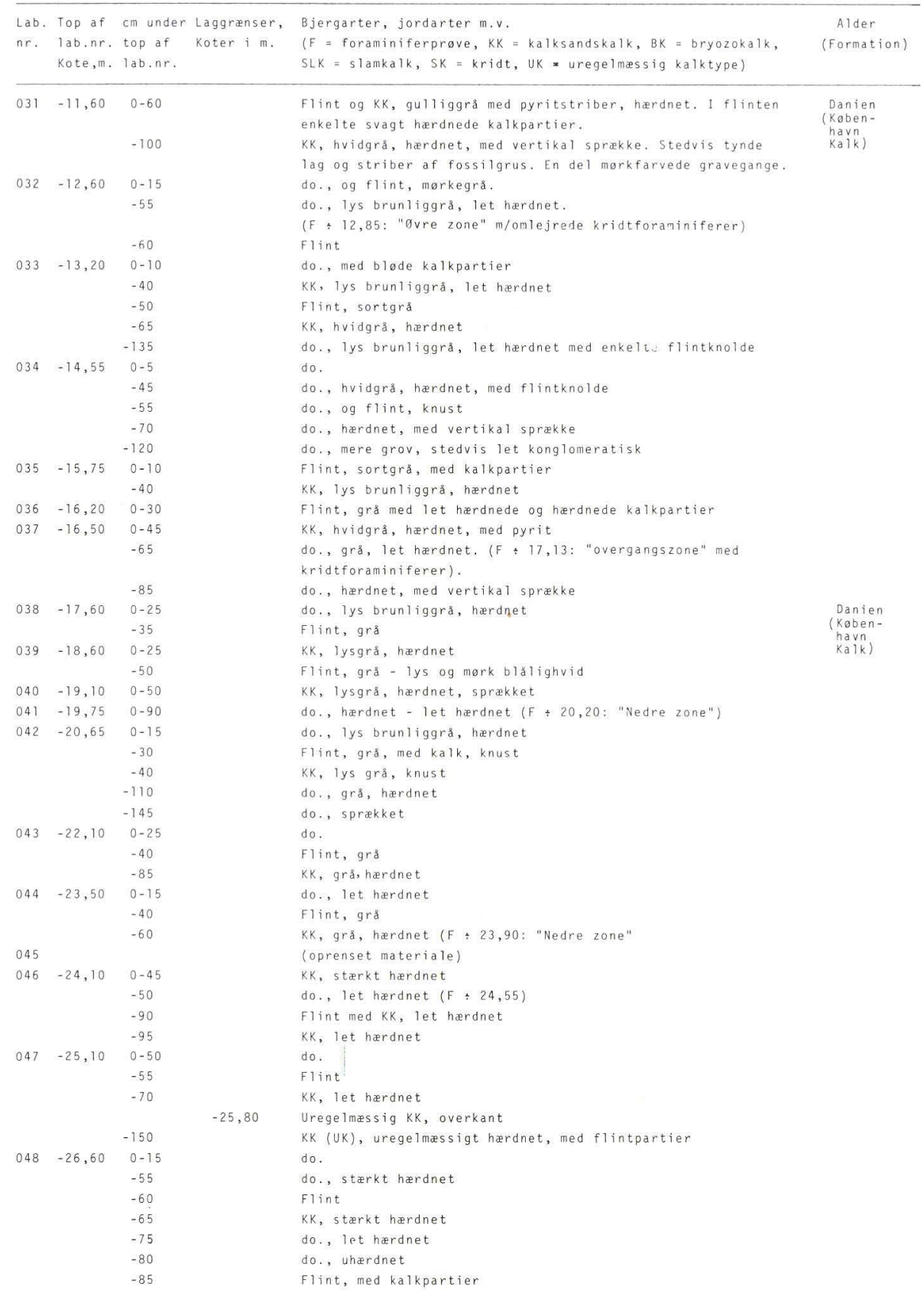




\begin{tabular}{|c|c|c|c|c|c|}
\hline $\begin{array}{l}\text { Lab. } \\
\text { nir. }\end{array}$ & $\begin{array}{l}\text { Top af } \\
\text { lab.nr. } \\
\text { Kote, m. }\end{array}$ & $\begin{array}{l}\mathrm{cm} \text { under } \\
\text { top af } \\
\text { lab.nr. }\end{array}$ & $\begin{array}{l}\text { Laggrænser, } \\
\text { Koter i m. }\end{array}$ & $\begin{array}{l}\text { Bjergarter, jordarter } m . v . \\
(F=\text { foraminiferprove, } K K=k a 1 k \text { sandskalk, } B K=\text { bryozokalk, } \\
S L K=\text { slamkalk, } S K=k r i d t, U K=\text { uregelmæssig kalktype })\end{array}$ & $\begin{array}{l}\text { Alder } \\
\text { (Formation) }\end{array}$ \\
\hline 049 & $-27,95$ & $\begin{array}{r}0-40 \\
-60 \\
-90\end{array}$ & & $\begin{array}{l}\text { KK (UK), stærkt hærdnet, med forkislinger } \\
\text { do., let hærdnet } \\
\text { do., varierende hærdnet, med forkislinger og flint }\end{array}$ & $\begin{array}{l}\text { Danien } \\
\text { (Køben- } \\
\text { havn } \\
\text { Ka1k) }\end{array}$ \\
\hline 050 & $-29,25$ & $\begin{array}{l}0-25 \\
-35 \\
-65 \\
-70 \\
-80 \\
-95 \\
-100 \\
-115\end{array}$ & & $\begin{array}{l}\text { KK, let hærdnet, stærkt sprækket } \\
\text { do., hærdnet } \\
\text { KK (UK), hvidlig, stærkt hærdnet } \\
\text { do, hærdnet } \\
\text { do., stærkt hærdnet } \\
\text { Flint } \\
\text { KK, let hærdnet } \\
\text { do., stærkt hærdnet }\end{array}$ & \\
\hline 051 & $-30,55$ & $\begin{array}{l}0-5 \\
-15 \\
-25 \\
-30 \\
-40 \\
-45 \\
-70 \\
-85\end{array}$ & & $\begin{array}{l}\text { do., let hærdnet } \\
\text { do., hærdnet, med flint } \\
\text { Flint, med kalkpartier } \\
\text { Kk, let hærdnet } \\
\text { do., stærkt hærdnet } \\
\text { Flint, med kalk } \\
\text { KK, stærkt hærdnet } \\
\text { Flint, med kalkpartier }\end{array}$ & \\
\hline 052 & $-31,75$ & $\begin{array}{r}0-35 \\
-85\end{array}$ & & $\begin{array}{l}\text { do., og KK, stærkt sprækket } \\
\text { do. }\end{array}$ & \\
\hline 053 & $-32,65$ & $\begin{array}{r}0-10 \\
-35 \\
-85\end{array}$ & & $\begin{array}{l}\text { do., med kalkpartier } \\
\text { kk, let leret, let hærdnet, knust } \\
\text { Flint, grå og hvid, med kalkpartier }\end{array}$ & \\
\hline $\begin{array}{l}054 \\
055\end{array}$ & $\begin{array}{l}-33,70 \\
\text { udgár }\end{array}$ & $0-50$ & & do., med uhærdnet og stærkt hærdnet kalk & \\
\hline 056 & $-34,20$ & $0-20$ & & do. & \\
\hline 057 & $-34,40$ & $0-5$ & & do., med kalkparti & \\
\hline 058 & $-34,50$ & $0-30$ & & do., lysgră - hvidgră & \\
\hline 059 & $-35,25$ & $\begin{array}{r}0-20 \\
-40\end{array}$ & & $\begin{array}{l}\text { do., med parti af kalksilt, leret, morkegra } \\
\text { KK, stærkt hærdnet og let hærdnet }\end{array}$ & \\
\hline 060 & $-35,80$ & $\begin{array}{r}0-20 \\
-50 \\
-55\end{array}$ & & $\begin{array}{l}\text { do., og flint, knust } \\
\text { do., hærdnet og stærkt hærdnet } \\
\text { do., og flint }\end{array}$ & \\
\hline 061 & $-37,05$ & $\begin{array}{r}0-20 \\
-40\end{array}$ & & $\begin{array}{l}\text { do., nedmalet } \\
\text { Flint, knust }\end{array}$ & \\
\hline 062 & $-38,65$ & $0-30$ & & do., stærkt sprækket. & \\
\hline 063 & $-39,05$ & $\begin{array}{r}0-15 \\
-35\end{array}$ & & $\begin{array}{l}\text { do. } \\
\text { kK, hvidgra, stærkt hærdnet, med enkelte blode, grå partier }\end{array}$ & \\
\hline 064 & $-40,30$ & $0-45$ & & Flint (forkislet UK) med hærdnede kalkpartier & \\
\hline 065 & $-41,65$ & $\begin{array}{r}0-40 \\
-45\end{array}$ & & $\begin{array}{l}\text { KK, hærdnet, med lidt flint } \\
\text { Flint, morkegră }\end{array}$ & \\
\hline 066 & $-42,55$ & $\begin{array}{r}0-15 \\
-25 \\
-60\end{array}$ & & $\begin{array}{l}\text { KK, tæt, hvidlig, stærkt hærdnet, med flintpartier } \\
\text { Flint med kalkpartier } \\
\text { KK, stærkt hærdnet, med flintpartier }\end{array}$ & \\
\hline 067 & $-43,05$ & $\begin{array}{r}0-10 \\
-30\end{array}$ & & $\begin{array}{l}\text { do., og flint, knust } \\
\text { Flint, med kalkpartier }\end{array}$ & \\
\hline 068 & $-44,00$ & $\begin{array}{r}0-30 \\
-40\end{array}$ & & $\begin{array}{l}\text { do., og kalk, knust } \\
\text { kk, hærdnet }\end{array}$ & \\
\hline 069 & $-44,45$ & $0-45$ & & $\begin{array}{l}\text { do., hærdnet og stærkt hærdnet med meget flint i uregelmæssigt } \\
\text { formede partier. Flinten viser en zonar opbygning med en morke- } \\
\text { gra kerne af tæt, kalkholdig flint omgivet af en millimetertynd } \\
\text { kappe af porøs, hvid flint. Flinten omgives af en kappe af kK, } \\
\text { mork gulliggra, ret grov, let hærdnet. Yderst findes KK, hvid, } \\
\text { stærkt hærdnet }\end{array}$ & \\
\hline 070 & $-44,90$ & $\begin{array}{r}0-10 \\
-40 \\
-45\end{array}$ & & $\begin{array}{l}\text { Flint med kalkpartier } \\
\text { KK, stærkt hærdnet, med enkelte flintpartier. } \\
\text { do., hærdnet }\end{array}$ & \\
\hline
\end{tabular}




\begin{tabular}{|c|c|c|c|c|c|}
\hline $\begin{array}{l}\text { Lab. } \\
\text { nr. }\end{array}$ & $\begin{array}{l}\text { Top af } \\
\text { lab. } n \text { r. } \\
\text { Kote, m. }\end{array}$ & $\begin{array}{l}\mathrm{cm} \text { under } \\
\text { top af } \\
\text { lab.nr. }\end{array}$ & $\begin{array}{l}\text { Laggrænser, } \\
\text { Koter i } \mathrm{m} \text {. }\end{array}$ & $\begin{array}{l}\text { Bjergarter, jordarter } m . v . \\
(F=\text { foraminiferprove, } K K=k a l k s a n d s k a l k, B K=\text { bryozokalk, } \\
S L K=\text { slamkal } k, S K=k r i d t, U K=\text { uregelmæssig kalktype })\end{array}$ & $\begin{array}{l}\text { Alder } \\
\text { (Formation) }\end{array}$ \\
\hline 070 & $-44,90$ & -55 & & Flint, sprækket & Danien \\
\hline \multirow[t]{3}{*}{071} & $-45,45$ & $0-15$ & & do. og kalk, knust & $\begin{array}{l}\text { (Køben- } \\
\text { havn }\end{array}$ \\
\hline & & -25 & & do. & \\
\hline & & -30 & & KK, hærdnet & \\
\hline \multirow[t]{2}{*}{072} & $-45,70$ & $0-5$ & & do., leret, let hærdnet & \\
\hline & & -10 & & Flint & \\
\hline \multirow[t]{4}{*}{073} & $-45,80$ & $0-5$ & & do., tæt, sort (kalkfri) & \\
\hline & & -15 & & KK, hærdnet, med lerstriber & \\
\hline & & -20 & & Flint, uregelmæssig & \\
\hline & & -30 & & KK, grå, let leret, hærdnet & \\
\hline \multirow[t]{4}{*}{074} & $-46,25$ & $0-35$ & & do. & \\
\hline & & -50 & & Flint, lys og mork gra & \\
\hline & & -70 & & KK, hardnet & \\
\hline & & -85 & & Flint, overvejende sortgră & \\
\hline \multirow[t]{5}{*}{075} & $-47,10$ & $0-20$ & & do. & \\
\hline & & -30 & & Kk, let hærdnet, med flint, knust & \\
\hline & & -45 & & & \\
\hline & & -60 & & do., hardnet & \\
\hline & & -70 & & do., stærkt hærdnet, med flint ( F $: 47,35)$ & \\
\hline \multirow[t]{3}{*}{076} & $-47,95$ & $0-20$ & & do. & \\
\hline & & -30 & & do., let hærdnet & \\
\hline & & -45 & & Flint og kalk, knust $(F \div 48,15)$ & \\
\hline \multirow[t]{4}{*}{077} & $-48,50$ & $0-25$ & & KK, stærkt hærdnet & \\
\hline & & -45 & & Flint, sort, med enkelte uhærdnede kalksandpartier & \\
\hline & & -60 & & KK, stærkt hærdnet & \\
\hline & & -70 & & do., let hardnet $(F \div 49,15)$ & \\
\hline \multirow[t]{4}{*}{078} & $-49,60$ & $0-5$ & & do., lost lejret, med enkelte bryozoer & \\
\hline & & -15 & & Flint, sort & \\
\hline & & -40 & & $\begin{array}{l}\text { KK, lys grå, med enkelte bryozoer og flint, } \\
\text { overvejende let hærdnet }(F=49,60 \text { og } \div 49,90)\end{array}$ & \\
\hline & & & $-50,25$ & Bryozokalk, overkant & Danien \\
\hline \multirow[t]{5}{*}{079} & $-50,25$ & $0-40$ & & $\begin{array}{l}\text { BK, slamrig, glaukonitholdig, stærkt hærdnet. } \\
\text { Antagelig hardground }\end{array}$ & $\begin{array}{l}\text { (Bryozo- } \\
\text { kalk- }\end{array}$ \\
\hline & & -50 & & do. stærkt hærdnet, med flint & enheden) \\
\hline & & -60 & & do., let hærdnet & \\
\hline & & -70 & & Flint & \\
\hline & & -85 & & BK, slamrig, hardnet $(F \div 50,80)$ & \\
\hline \multirow[t]{2}{*}{080} & $-51,10$ & $0-30$ & & Flint, grå og sort & \\
\hline & & -45 & & BK, slamrig, let hærdnet, stærkt sprækket & \\
\hline \multirow[t]{3}{*}{081} & $-57,70$ & $0-75$ & & do., hærdnet. & \\
\hline & & -20 & & Flint & \\
\hline & & -40 & & BK, slamrig, stærkt hardnet, med $\mathrm{flint}$ & \\
\hline \multirow[t]{4}{*}{082} & $-52,15$ & $0-25$ & & Flint & \\
\hline & & -40 & & BK, slamrig, hærdnet, med lidt flint & \\
\hline & & -50 & & do., let hardnet og flint & \\
\hline & & -60 & & do., hardnet $(F \div 52,55)$ & \\
\hline \multirow[t]{5}{*}{083} & $-52,85$ & $0-20$ & & do., stærkt hærdnet & \\
\hline & & -30 & & do., hærdnet & \\
\hline & & -40 & & do., let hardnet & \\
\hline & & -105 & & do., stærkt hærdnet med lidt flint & \\
\hline & & -115 & & do., let hærdnet $(F \div 53,20)$ & \\
\hline 084 & $-54,35$ & $0-35$ & & do., stærkt hardnet og flint & \\
\hline \multirow[t]{5}{*}{085} & $-54,75$ & $0-10$ & & Flint & \\
\hline & & -20 & & BK, slamrig, stærkt hærdnet & \\
\hline & & -40 & & do., leret, let hærdnet & \\
\hline & & -45 & & do., slamrig, starkt hardnet, med flint & \\
\hline & & -75 & & do., stærkt hærdnet og let hardnet & \\
\hline 086 & $-55,50$ & $\begin{array}{r}0-25 \\
-40\end{array}$ & & $\begin{array}{l}\text { do., stærkt hærdnet, ned flint } \\
\text { do., leret }\end{array}$ & \\
\hline
\end{tabular}




\begin{tabular}{|c|c|c|c|c|c|}
\hline $\begin{array}{l}\text { Lab. } \\
n r \text {. }\end{array}$ & $\begin{array}{l}\text { Top af } \\
\text { lab.nr. } \\
\text { Kote, m. }\end{array}$ & $\begin{array}{l}\mathrm{cm} \text { under } \\
\text { top af } \\
\text { lab.nr. }\end{array}$ & $\begin{array}{l}\text { Laggrænser, } \\
\text { Koter i m. }\end{array}$ & $\begin{array}{l}\text { Bjergarter, jordarter } m \cdot V . \\
(F=\text { foraminiferprove, } K K=\text { Kalksandskalk, } B K=\text { bryozokalk } \\
S L K=\text { slamkalk, } S K=k r i d t, U K=\text { uregelmæssig kalktype })\end{array}$ & $\begin{array}{l}\text { Alder } \\
\text { (Formation) }\end{array}$ \\
\hline 086 & $-55,50$ & $\begin{array}{l}-45 \\
-50 \\
-55 \\
-60 \\
-80 \\
-130 \\
-140 \\
-150\end{array}$ & & $\begin{array}{l}\text { Flint } \\
\text { BK, slamrig, leret, hærdnet } \\
\text { Mergel, sortgra, let hærdnet } \\
\text { BK, slamrig, hærdnet } \\
\text { do., stærkt hærdnet } \\
\text { do., let hærdnet og stærkt hærdnet med flint } \\
\text { Kalksand, finkornet, let hærdnet } \\
\text { Flint med kalkpartier }(F .+56,0 \text { og } \div 56,40)\end{array}$ & $\begin{array}{l}\text { Danien } \\
\text { (Bryozo- } \\
\text { kalk- } \\
\text { enheden) }\end{array}$ \\
\hline 087 & $-57,35$ & $\begin{array}{l}0-40 \\
-65 \\
-70 \\
-85 \\
-105 \\
-160\end{array}$ & & $\begin{array}{l}\text { BK, slamrig, stærkt hærdnet } \\
\text { do., let hærdnet } \\
\text { do., stærkt hærdnet, med flint } \\
\text { do., let hærdnet } \\
\text { do., stærkt hærdnet, med flint } \\
\text { do., stærkt hærdnet og let hærdnet, nederst med lidt flint } \\
(F \div 57,95 \text { og } \div 58,80)\end{array}$ & \\
\hline 088 & & $\begin{array}{r}0-20 \\
-50\end{array}$ & & $\begin{array}{l}\text { do, , hærdnet og stærkt hærdnet } \\
\text { Flint, sortgra, stærkt sprækket }\end{array}$ & \\
\hline 089 & & $\begin{array}{r}0-30 \\
-40 \\
-60 \\
-70\end{array}$ & & $\begin{array}{l}\text { do., med kalk, stærkt hærdnet } \\
\text { BK, slamrig, stærkt hærdnet } \\
\text { do., let hærdnet } \\
\text { do., stærkt hærdnet, med flint }\end{array}$ & \\
\hline 090 & $-60,70$ & $\begin{array}{r}0-10 \\
-35 \\
-55 \\
-90\end{array}$ & & $\begin{array}{l}\text { Flint } \\
\text { BK, slamrig, let - stærkt hærdnet } \\
\text { Flint } \\
\text { BK, slamrig, stærkt hærdnet }\end{array}$ & \\
\hline 091 & $-61,80$ & $\begin{array}{l}0-5 \\
-30\end{array}$ & & $\begin{array}{l}\text { Flint med kalkpartier } \\
\text { BK, slamrig, hærdnet og let hærdnet }\end{array}$ & \\
\hline 092 & $-62,35$ & $\begin{array}{r}0-5 \\
-15 \\
-45 \\
-50\end{array}$ & & $\begin{array}{l}\text { Flint med kalk } \\
\text { BK, meget slamrig, stærkt hærdnet } \\
\text { do., let hærdnet og hærdnet, nederst med flint } \\
\text { Flint med BK, stærkt hærdnet }\end{array}$ & \\
\hline 093 & $-62,95$ & $\begin{array}{r}0-15 \\
-30 \\
-45 \\
-60 \\
-65 \\
-80\end{array}$ & & $\begin{array}{l}\text { do., sort } \\
\text { BK, meget slamrig, stærkt hærdnet med flint } \\
\text { do., let hærdnet, med lerslirer } \\
\text { do., stærkt hærdnet, med flint } \\
\text { do., hærdnet } \\
\text { Flint, sort, med kalkpartier, knust }\end{array}$ & \\
\hline 0.94 & $-63,90$ & $\begin{array}{l}0-5 \\
-15 \\
-35 \\
-40 \\
-45 \\
-55 \\
-75\end{array}$ & & $\begin{array}{l}\text { do. } \\
\text { Kalk, finkornet, hærdnet, med enkelte bryozoer } \\
\text { Flint, sort, med kalk, stærkt hærdnet } \\
\text { Kalk, grå, finkornet, leret, let hærdnet } \\
\text { do., stærkt hærdnet } \\
\text { do., med flint } \\
\text { do., let hærdnet og hærdnet }\end{array}$ & \\
\hline 095 & $-64,65$ & $\begin{array}{r}0-25 \\
-45 \\
-60 \\
-80 \\
-110\end{array}$ & & $\begin{array}{l}\text { do., hærdnet, med flint } \\
\text { Flint, sortgra } \\
\text { Kalk, finkornet, hærdnet } \\
\text { do., lysgra, med lerslirer og mid enkelte bryozoer, } \\
\text { let hærdnet } \\
\text { do., finkornet, hærdnet, sprækket og knust }\end{array}$ & \\
\hline 096 & $-65,75$ & $\begin{array}{r}0-15 \\
-25 \\
-30 \\
-65\end{array}$ & & $\begin{array}{l}\text { do., stærkt hærdnet } \\
\text { do., let hærdnet } \\
\text { do., stærkt hærdnet, med flint } \\
\text { do., hærdnet }\end{array}$ & \\
\hline 097 & $-66,60$ & $\begin{array}{r}0-30 \\
-40\end{array}$ & & $\begin{array}{l}\text { do. } \\
\text { Flint, sortgrå }\end{array}$ & \\
\hline 098 & $-67,05$ & $\begin{array}{l}0-5 \\
-30\end{array}$ & & $\begin{array}{l}\text { do. } \\
\text { Kalk, finkornet, stærkt hærdnet, med flint }\end{array}$ & \\
\hline
\end{tabular}




\begin{tabular}{|c|c|c|c|c|c|}
\hline $\begin{array}{l}\text { Lab. } \\
\text { nr. }\end{array}$ & $\begin{array}{l}\text { Top af } \\
\text { lab.nr. } \\
\text { Kote, m. }\end{array}$ & $\begin{array}{l}\text { cm under } \\
\text { top af } \\
\text { lab.nr. }\end{array}$ & $\begin{array}{l}\text { Laggrænser, } \\
\text { Koter i m. }\end{array}$ & $\begin{array}{l}\text { Bjergarter, jordarter } m . v . \\
(F=\text { foraminiferprøve, } K K=k a 1 k s a n d s k a l k, B K=\text { bryozokalk, } \\
S L K=\text { slamkalk, } S K=k r i d t, U K=\text { uregelmæssig kalktype })\end{array}$ & $\begin{array}{c}\text { Alder } \\
\text { (Formation) }\end{array}$ \\
\hline 099 & $-67,40$ & $\begin{array}{l}0-5 \\
-10 \\
-30 \\
-50\end{array}$ & & $\begin{array}{l}\text { Flint } \\
\text { Kalkbreccie, delvis omdannet t } 11 \text { flint } \\
\text { Kalk, finkornet, stærkt hæronet, sprækket } \\
\text { Flint med kalkpartier }\end{array}$ & $\begin{array}{l}\text { Danien } \\
\text { (Bryozo- } \\
\text { kalk- } \\
\text { enheden) }\end{array}$ \\
\hline 100 & $-68,20$ & $\begin{array}{r}0-25 \\
-30\end{array}$ & & $\begin{array}{l}\text { do., } \\
\text { kalk, finkornet, hærdnet }\end{array}$ & \\
\hline 101 & $-68,50$ & $\begin{array}{l}0-5 \\
-25\end{array}$ & & $\begin{array}{l}\text { do., med enkelte bryozoer og flint } \\
\text { Flint }\end{array}$ & \\
\hline 102 & $-68,75$ & $\begin{array}{l}0-5 \\
-15 \\
-25 \\
-75\end{array}$ & & $\begin{array}{l}\text { do. } \\
\text { Kalk, finkornet, hærdnet, sprækket } \\
\text { do. med flint } \\
\text { do., med lerslirer }\end{array}$ & \\
\hline 103 & $-69,65$ & $\begin{array}{l}0-5 \\
-20 \\
-25 \\
-40\end{array}$ & & $\begin{array}{l}\text { Flint, med kalk, stærkt hærdnet } \\
\text { Kalk, finkornet, stærkt hærdnet } \\
\text { Flint } \\
\text { Kalk, finkornet, stærkt hærdnet }\end{array}$ & \\
\hline 104 & $-70,50$ & $\begin{array}{l}0-5 \\
-25 \\
-30 \\
-40 \\
-50\end{array}$ & & $\begin{array}{l}\text { Flint } \\
\text { Kalk, finkornet, stærkt hærdnet } \\
\text { do. hærdnet } \\
\text { do., let leret, let hærdnet } \\
\text { do., finkornet, stærkt hærdnet }\end{array}$ & \\
\hline 105 & $-71,00$ & $\begin{array}{l}0-30 \\
-50 \\
-120\end{array}$ & & $\begin{array}{l}\text { do. } \\
\text { do., huidlig, og flint } \\
\text { do., finkornet, stærkt hærdnet }(F \div 71,95)\end{array}$ & \\
\hline 10.6 & $-72,20$ & $\begin{array}{r}0-20 \\
-25 \\
-35\end{array}$ & & $\begin{array}{l}\text { do. } \\
\text { Flint, med kalkpartier } \\
\text { Kalk, finkornet, stærkt hærdnet }\end{array}$ & \\
\hline 107 & $-72,55$ & $\begin{array}{l}0-20 \\
-90 \\
-120 \\
-165 \\
-180 \\
-215\end{array}$ & & $\begin{array}{l}\text { do., let leret, hærdnet og let hærdnet } \\
\text { do., starkt hærdnet, med flint } \\
\text { do., hærdnet } \\
\text { do., stærkt hærdnet, med lidt flint } \\
\text { Flint } \\
\text { Kalk, grá, finkornet, overvejende hærdnet, } \\
\text { stedvis med lerslirer (F: }: 73,85 \text { og } * 74,60) \text {. }\end{array}$ & \\
\hline 108 & $-74,70$ & $\begin{array}{l}0-20 \\
-120 \\
-125 \\
-160 \\
-170 \\
-175 \\
-190 \\
-230 \\
-240\end{array}$ & & $\begin{array}{l}\text { do., hvidlig, hærdnet } \\
\text { do., finkornet, hærdnet, med lidt flint } \\
\text { do., med mergelslirer (slumping ?), let hærdnet } \\
\text { do., hærdnet og let hærdnet } \\
\text { do., stærkt hærdnet, pletvis forkislet } \\
\text { do., let hærdnet } \\
\text { do., stærkt hærdnet, med flint } \\
\text { do., noget bryozoholdig, hærdnet og stærkt hærdnet } \\
\text { Flint, sort, med kalk, lys gra, bryozoholdig, stærkt hærdnet } \\
(F \div 75,85 \text { og } \div 76,20)\end{array}$ & \\
\hline 109 & $-77,10$ & $\begin{array}{r}0-20 \\
-90 \\
-95 \\
-140\end{array}$ & & $\begin{array}{l}\text { do., sortgra } \\
\text { Kalk, hvidlig, finkornet, hærdnet og stærkt hærdnet, } \\
\text { med lidt flint } \\
\text { Flint } \\
\text { Kalk, finkornet, bryozopræget, hærdnet og stærkt hærdnet }\end{array}$ & \\
\hline 110 & $-78,50$ & $\begin{array}{r}0-10 \\
-20 \\
-95\end{array}$ & & $\begin{array}{l}\text { do., med flint } \\
\text { do., let hærdnet } \\
\text { do., stærkt hærdnet, med lidt flint }\end{array}$ & \\
\hline 111 & $-79,50$ & $\begin{array}{l}0-25 \\
-26 \\
-35 \\
-115\end{array}$ & & $\begin{array}{l}\text { do., hærdnet, bryozopræget } \\
\text { Mergel, mark brunliggrå, fint lagde1t } \\
\text { Kalk, finkornet, hærdnet, bryozopræget } \\
\text { do., hærdnet og stærkt hærdnet, med ] idt flint }\end{array}$ & \\
\hline
\end{tabular}




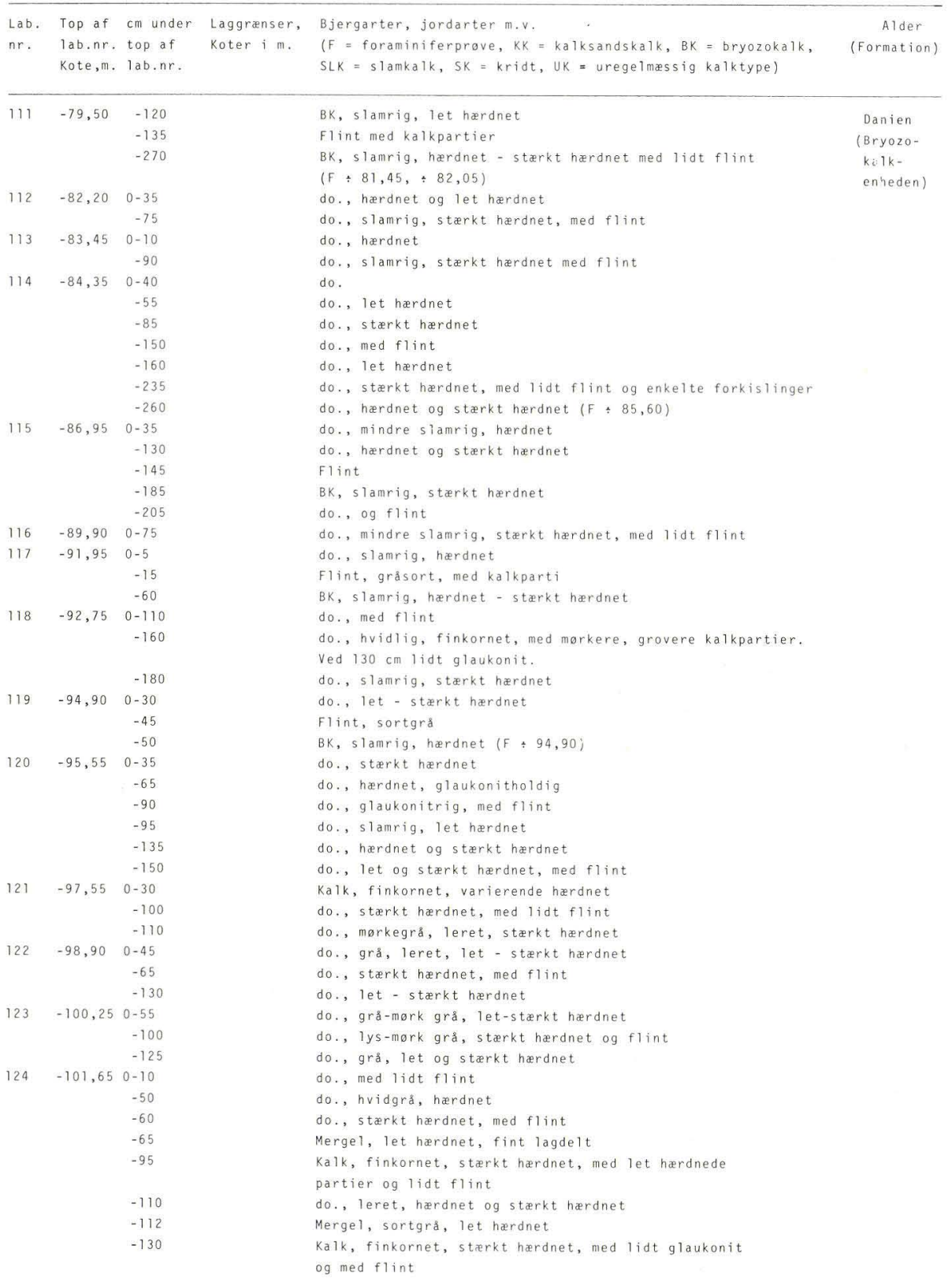




\begin{tabular}{|c|c|c|c|c|c|}
\hline $\begin{array}{l}\text { Lab. } \\
\text { nr. }\end{array}$ & $\begin{array}{l}\text { Top af } \\
\text { lab.nr. } \\
\text { Kote, m. }\end{array}$ & $\begin{array}{l}\text { cm under } \\
\text { top af } \\
\text { lab. nr. }\end{array}$ & $\begin{array}{l}\text { Laggrænser, } \\
\text { Koter i m. }\end{array}$ & $\begin{array}{l}\text { Bjergarter, jordarter } m . v . \\
(F=\text { foraminiferprove, } K K=k a l k s a n d s k a l k, B K=\text { bryozokalk, } \\
S L K=s l a m k a l k, \quad S K=k r i d t, U K=\text { uregelmæssig kalktype) }\end{array}$ & $\begin{array}{c}\text { Alder } \\
\text { (Formation) }\end{array}$ \\
\hline 124 & $-101,65$ & $\begin{array}{l}-145 \\
-150\end{array}$ & & $\begin{array}{l}\text { do., let hærdnet } \\
\text { do., hærdnet og let hærdnet (F } \div \text { 103,05: danien fauna) }\end{array}$ & Danien \\
\hline 125 & $-103,45$ & -120 & & $\begin{array}{l}\text { Top af kridt enheden } \\
\text { Kalksten, hvidlig, finkornet, stærkt hærdnet, med stejle } \\
\text { kalcitfyldte sprækker, med store glaukonitpletter og med } \\
\text { talrige uregelmæssige gravegange, der er udfyldt af } \\
\text { uhærdnet, ret groft, glaukonitpræget kalkmateriale } \\
\text { SLK (SK), hvid, let hærdnet, med stærkt hærdnede partier, } \\
\text { med glaukonitfyldte hulrum og med flint } \\
\text { do., hærdnet (F } \div 104,15 \text { : danien-senon blandingsfauna; } \\
F \div 104,50: \text { Pseudotextularia elegans faunizonen (senon) }\end{array}$ & $\begin{array}{l}\text { Maastricht- } \\
\text { ien }\end{array}$ \\
\hline 126 & $-105,25$ & $\begin{array}{r}0-25 \\
-55\end{array}$ & & $\begin{array}{l}\text { Flint, urege } 1 \text { mæs } 519 \text {, med } S L K \text {, let hærdnet } \\
\text { SLK, leret, stærkt hærdnet, med let hærdnede partier }\end{array}$ & \\
\hline 127 & $-106,95$ & $\begin{array}{l}0-5 \\
-15 \\
-85 \\
-125\end{array}$ & & $\begin{array}{l}\text { do., hvid } \\
\text { SLK (SK) og flint, hærdnet, med stærkt hærdnede partier } \\
\text { do., med mergelstriber } \\
\text { do., med enkelte mergelstriber, uhærdnet, og med flint } \\
(F+107,50,+107,95 \text {, begge P.elegans f.z.) }\end{array}$ & \\
\hline 128 & $-109,25$ & $\begin{array}{l}0-15 \\
-20 \\
-80 \\
-135\end{array}$ & & $\begin{array}{l}\text { do., hvidlig, hærdnet } \\
\text { do., forkislet og flint } \\
\text { do., med sma, lerede slirer, hærdnet - let hærdnet } \\
\text { do., hærdnet, med forkislede partier } \\
\text { (F } \div 109,45: 1 . \text { elegans f.z., } \div 110,40)\end{array}$ & \\
\hline 129 & $-111,05$ & $0-70$ & & $\begin{array}{l}\text { do., hvid, let hærdnet, med enkelte forkislinger og } \\
\text { lidt flint (F } \div 111,40: \text { F.elogans f.z.) }\end{array}$ & \\
\hline 130 & $-112,75$ & $\begin{array}{l}0-5 \\
-15 \\
-30 \\
-35 \\
-40 \\
-55 \\
-85\end{array}$ & & $\begin{array}{l}\text { do. } \\
\text { do., hvid, let hærdnet } \\
\text { do., leret } \\
\text { do., let hærdnet } \\
\text { do., delvis forkislet, og flint } \\
\text { do., hvid, hærdnet } \\
\text { do., stærkt hærdnet, delvis forkislet og flint } \\
\text { (F }=113,00: f \text { tegans f.z.) }\end{array}$ & \\
\hline 131 & $-114,05$ & $\begin{aligned} 0 & -10 \\
& -35 \\
& -170\end{aligned}$ & & $\begin{array}{l}\text { do., hærdnet } \\
\text { do., leret, let hærdnet } \\
\text { do., hærdnet, med enkelte lerslirer }(F=114,55)\end{array}$ & \\
\hline 132 & $-115,15$ & $\begin{array}{l}0-50 \\
-60 \\
-700 \\
-755 \\
-785\end{array}$ & & $\begin{array}{l}\text { do., let hærdnet, med enkelte flintpartier } \\
\text { do., forkislet og flint, grå } \\
\text { do., let hærdnet, med enkelte forkislede partier } \\
\text { do., hærdnet } \\
\text { do., hærdnet og delvis forkislet, flintlignende } \\
(F+115,25)\end{array}$ & \\
\hline 133 & $-117,05$ & $\begin{array}{l}0-5 \\
-15 \\
-20 \\
-100 \\
-225\end{array}$ & & $\begin{array}{l}\text { do. } \\
\text { do., hærdnet } \\
\text { do., hærdnet og delvis forkislet } \\
\text { do., let hærdnet, med lerede slirer og forkislinger } \\
\text { do., hærdnet med lerlag og lerslirer (fig. 2). Delvis udviklet } \\
\text { som "bänderkreide" } \\
\text { do., let hærdnet, ret leret ("bänderkreide") (F }=119,75 \text { : } \\
\text { F.eZegans f.z.) }\end{array}$ & \\
\hline 134 & $-120,00$ & $0-245$ & & do., hardnet, med pyritpletter & \\
\hline 135 & $-122,60$ & $0-70$ & & do., pletvis forkislet ("bänderkreide") & \\
\hline 136 & $-123,30$ & $\begin{array}{r}0-90 \\
-165 \\
-185\end{array}$ & $-725,20$ & $\begin{array}{l}\text { do., hærdnet, med vandrette } 7 \text { inser og arer af leret materiale } \\
\text { do., stærkt hærdnet, med flint } \\
\text { do., Teret, hærdnet. ( } F \div 124,85 \text { : Pseudouvigerina rugoog f.z.) } \\
\text { slutdybde }\end{array}$ & \\
\hline
\end{tabular}

